\title{
WestVirginiaUniversity
}

THE RESEARCH REPOSITORY @ WVU

Graduate Theses, Dissertations, and Problem Reports

2004

\section{Geotechnical investigation of Montrose wetland site}

Christopher R. Ryan

West Virginia University

Follow this and additional works at: https://researchrepository.wvu.edu/etd

\section{Recommended Citation}

Ryan, Christopher R., "Geotechnical investigation of Montrose wetland site" (2004). Graduate Theses, Dissertations, and Problem Reports. 1558.

https://researchrepository.wvu.edu/etd/1558

This Thesis is protected by copyright and/or related rights. It has been brought to you by the The Research Repository @ WVU with permission from the rights-holder(s). You are free to use this Thesis in any way that is permitted by the copyright and related rights legislation that applies to your use. For other uses you must obtain permission from the rights-holder(s) directly, unless additional rights are indicated by a Creative Commons license in the record and/ or on the work itself. This Thesis has been accepted for inclusion in WVU Graduate Theses, Dissertations, and Problem Reports collection by an authorized administrator of The Research Repository @ WVU. For more information, please contact researchrepository@mail.wvu.edu. 


\title{
GEOTECHNICAL INVESTIGATION OF MONTROSE WETLAND SITE
}

\author{
Christopher R. Ryan \\ Thesis submitted to the \\ College of Engineering and Mineral Resources \\ at West Virginia University \\ in partial fulfillment of the requirements \\ for the degree of \\ Master of Science \\ in \\ Civil Engineering
}

Hema Siriwardane, Ph.D., Chair

Udaya Halabe, Ph.D.

Roger Viadero, Ph.D.

Department of Civil and Environmental Engineering

\author{
Morgantown, West Virginia \\ 2004
}

Keywords: Hydraulic Barrier, Mitigation, Permeability, and Wetland 


\section{ABSTRACT \\ Geotechnical Investigation of Montrose Wetland Site}

\section{Christopher R. Ryan}

Mitigation for unavoidable impacts affecting natural wetlands has become a common issue in civil engineering. The goals today are to protect and preserve wetlands, not to destroy them as in earlier times. The restoration or the creation of a wetland is implemented with the policy of "no net loss". West Virginia has few wetlands due to the rugged ground terrain. Therefore, any impact on a natural wetland must be compensated for with the creation of an engineered wetland. Common methods involved with creating a wetland consist of excavation across the entire site down to the ground water table and then the placement of a horizontal hydraulic barrier. The installation of a vertical hydraulic barrier is a potentially effective and inexpensive solution to wetland creation. The placement of a vertical hydraulic barrier will only require excavation along a small trench line. The barrier can impede subsurface flow and cause the water to rise to the surface.

The purpose of this investigation is to obtain the geotechnical characteristics of the site and to aid in the creation of a proposed engineered wetland at Montrose, West Virginia. The tests performed in the laboratory to obtain the soil properties were: water content, Atterberg limits (liquid and plastic limits), grain size (sieve analysis and hydrometer), specific gravity, field density, and hydraulic conductivity. Tests were performed on soil samples taken from the site during installation of monitoring wells. Results from tests were used in the classification of soil. Additional samples were reconstructed to determine the permeability of the soil. These tests were performed in accordance with the American Society for Testing and Materials (ASTM) and American Association of State Highway and Transportation Officials (AASHTO) standards. The classification of the soil was performed in accordance to AASHTO and Unified Soil Classification System (USCS) guidelines.

The results show that the installation of vertical hydraulic barrier at the site should create the suitable conditions necessary to establish a wetland habitat. The barrier can impede the ground water from flowing into Laurel Run Creek and cause it to rise to the surface. Tests performed in the laboratory show that an impermeable layer exists at a depth of ten feet and would provide a suitable area to anchor the barrier into the ground. Geotechnical properties of the soil at the site show that this location is a suitable candidate for wetland creation. 


\section{ACKNOWLEDGMENTS}

The author would like to take this opportunity to thank the people who helped in the completion of this thesis. Special thanks to Dr. Hema Siriwardane, graduate advisor and committee chairperson, for his assistance and guidance in completion of this thesis. The author would also like to thank Dr. Udaya Halabe and Dr. Roger Viadero for their participation on the committee.

Thanks to the West Virginia Division of Highways for the financial support through a research contract with West Virginia University. The author would also like to thank friends and family for the support during completion of thesis. 


\section{TABLE OF CONTENTS}

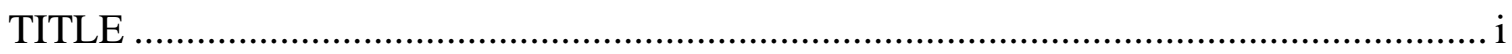

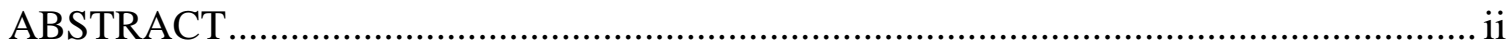

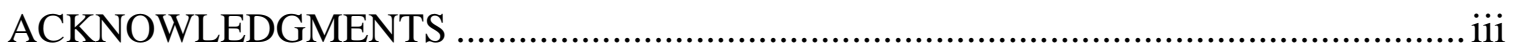

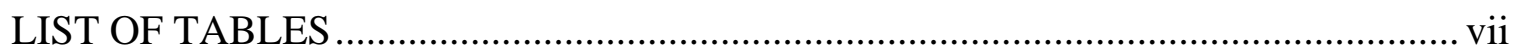

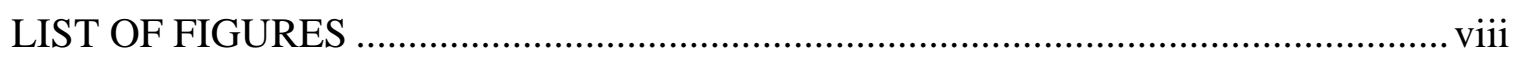

CHAPTER 1: INTRODUCTION ........................................................................ 1

$1.1 \quad$ Problem Statement ............................................................................. 1

1.2 Benefits of Wetlands .............................................................................. 3

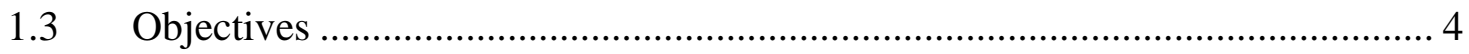

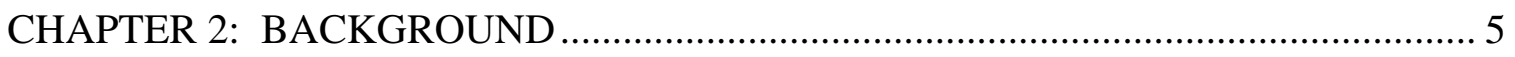

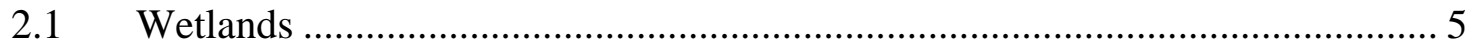

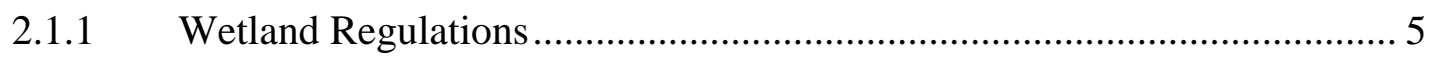

2.1.2 Wetland Types and Formations ...................................................... 10

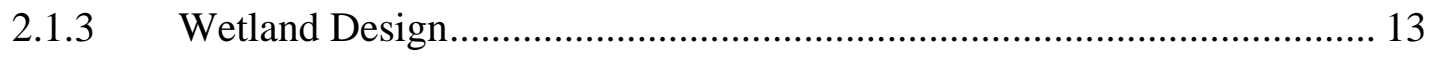

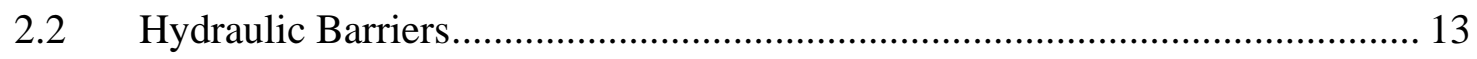

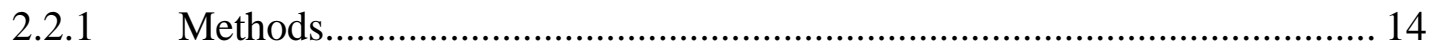

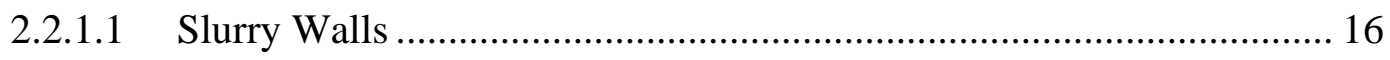

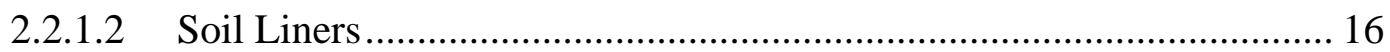

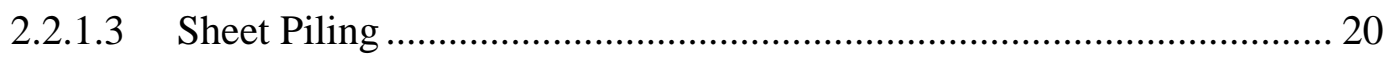

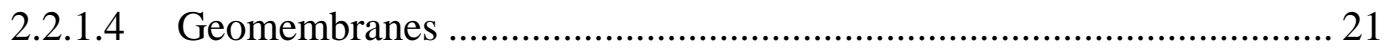

2.2.1.5 Geosynthetic Clay Liner ...................................................... 21

CHAPTER 3: DESCRIPTION OF FIELD SITE ................................................... 24 


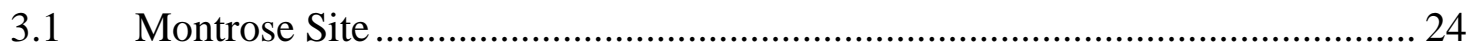

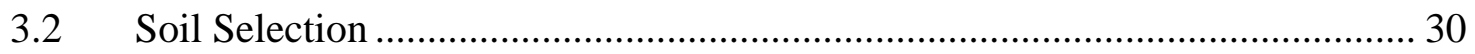

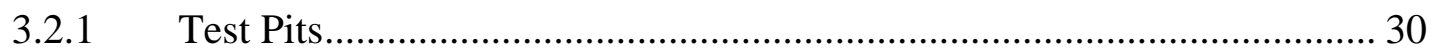



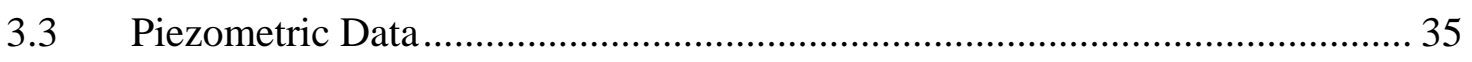



3.3.2 Deep Monitoring Wells............................................................................ 38

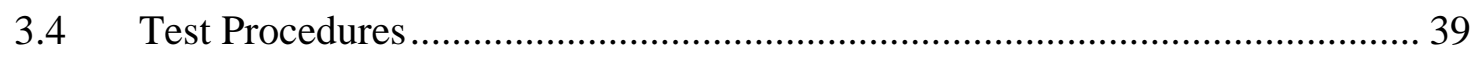

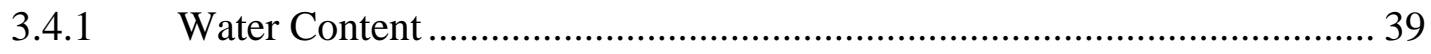

3.4.2 Atterberg Limits ............................................................................. 40

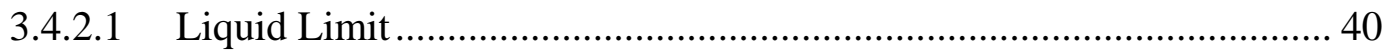

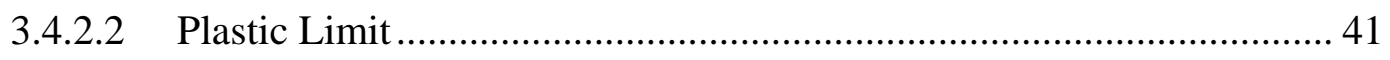

3.4.3 Grain Size

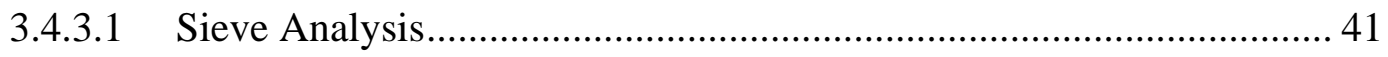

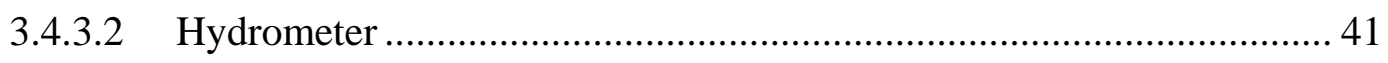

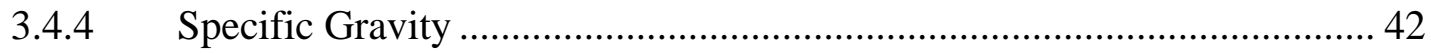

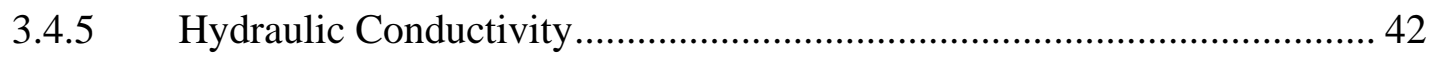

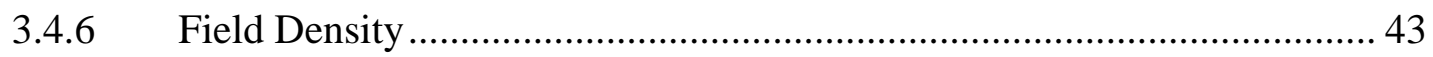



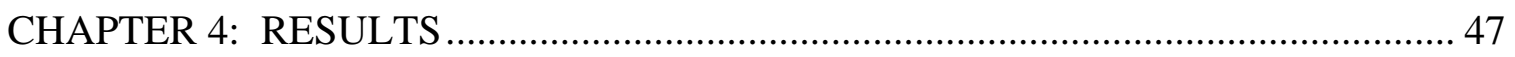

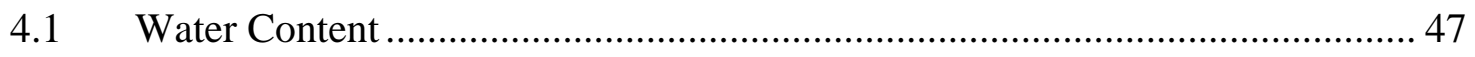






$4.4 \quad$ Hydraulic Conductivity ...................................................................... 51

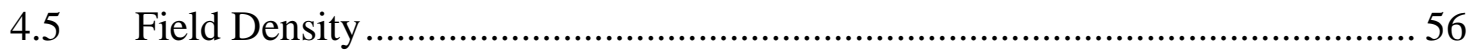

4.6 Grain Size......................................................................................... 56

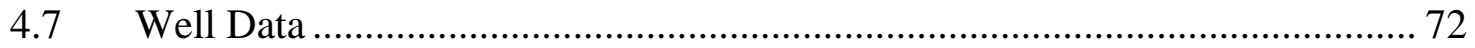

4.8 Soil Classification ............................................................................. 74



5.1 Engineering of a Wetland ................................................................... 91

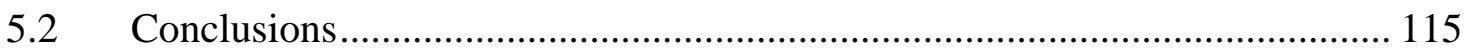

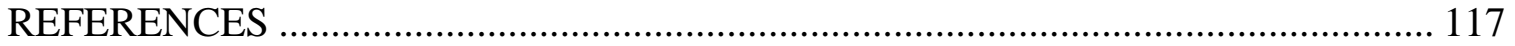



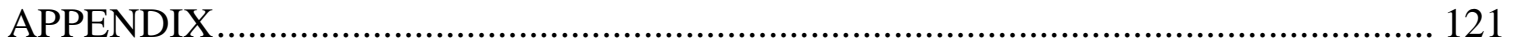

Appendix A: Montrose Wetland Monitoring Well Data. ...................................... 121

Appendix B: Grain Size Analysis Data, Hydrometer Test. .................................... 131

Appendix C: Montrose Monitoring Well Readings.............................................. 146

Appendix D: Water Content Graphs Plotted Versus Depth................................... 176 


\section{LIST OF TABLES}

Table 2-1: List of Legislation for wetland protection in United States (Turner and

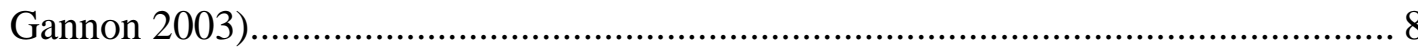

Table 2-2: Table of different types of variations of wetlands (Smith and Smith 2001).. 11

Table 4-1: Water Content at each Depth for Montrose Wetland.................................. 47

Table 4-2: Average Water Content for Montrose Wetland Site. .................................. 48

Table 4-3: Atterberg Limits for Each Depth at Montrose Site. .................................. 48

Table 4-4: Specific Gravity for Montrose Site. .................................................... 50

Table 4-5: Hydraulic Conductivity Values........................................................... 51

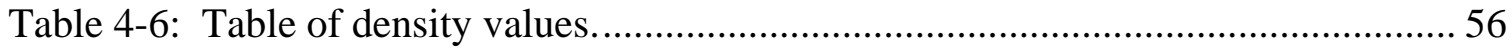

Table 4-7: Minimum, Maximum, and Average readings of the piezometric ground surface for the shallow wells from June 2001 to June 2004................................ 72

Table 4-8: Minimum, Maximum, and Average readings of the piezometric ground surface for the deep wells from October 2002 to June 2004 ................................ 73

Table 4-9: AASHTO Soil Classification for Montrose Wetland Site............................ 74

Table 4-10: USCS Soil Classification for Montrose Wetland Site.............................. 75

Table 5-1: Hydraulic Conductivity Values at Montrose Site..................................... 106

Table 5-2: Density Results from laboratory testing............................................... 106

Table 5-3: Average Water Content and Specific Gravity Values at Montrose Site. .... 107

Table 5-4: Classification of Soil at a Depth of Ten Feet. ........................................ 111 


\section{LIST OF FIGURES}

Figure 2-1: Extent of the world's Wetlands (Mitsch and Gosselink 2000)..................... 6

Figure 2-2: Richards Barrier (Frind, Gillham, and Pickens 1976). ............................. 15

Figure 2-3: Schematic of Slurry Wall Barrier (Johnson et al. 1985)............................ 17

Figure 2-4: Typical landfill cover section (Mundell and Bailey 1985)........................ 18

Figure 2-5: Schematic of Sheet Pile Installation (GeoCal 2004)................................. 20

Figure 2-6: Installation process of a Geosynthetic Clay Liner (GCL) (Mapson 2004)... 23

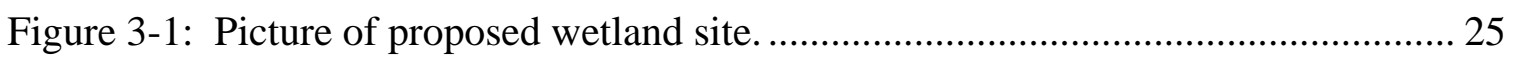

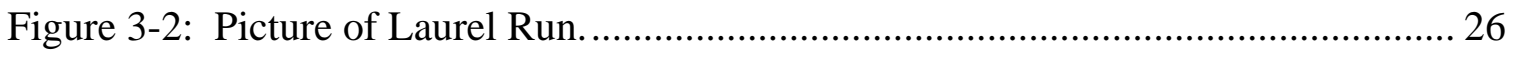

Figure 3-3: Map of North Central West Virginia showing location of project site

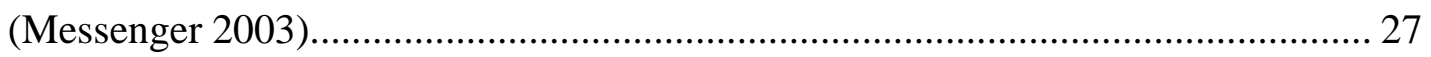

Figure 3-4: Aerial Picture showing boundaries at Montrose Wetland site (WVGISTC



Figure 3-5: Schematic of topographic survey and location of control stations at Montrose

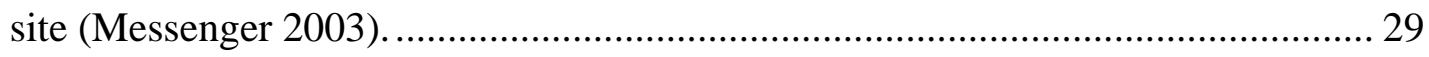

Figure 3-6: (a) Typical soil profile for TP-1 through TP-4, and (b) Typical soil profile

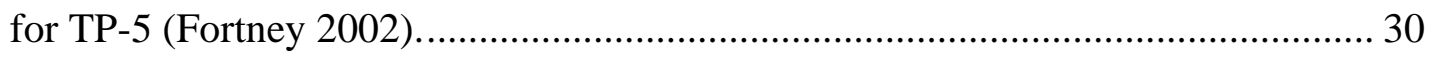

Figure 3-7: Schematic of site showing the five test pits (WVGISTC 2000).................. 31

Figure 3-8: Schematic of site showing the 15 boreholes and the 2 recorders (WVGISTC

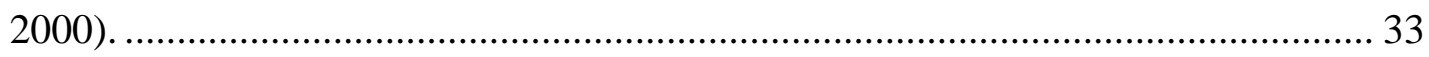

Figure 3-9: Picture of rotary drill used during borehole completion (Messenger 2003). 34

Figure 3-10: Picture of Shallow Monitoring Well at Montrose Wetland Site................ 35 
Figure 3-11: Schematic of Montrose Site showing all Monitoring Wells (WVGISTC 2000) 36

Figure 3-12: Schematic of Monitoring Well Device of: (a) a Shallow Monitoring Well Device and (b) a WL-40 Automated Water Level Recorder (Messenger 2003)...... 37

Figure 3-13: Picture of Deep Monitoring Well at Montrose Wetland Site..................... 38

Figure 3-14: Schematic of Deep Monitoring Well Device (Messenger 2003)............... 39

Figure 3-15: AASHTO Classification Table (Das 1998). .......................................... 45

Figure 3-16: USCS Soil Classification Table (Das 1998)........................................ 46

Figure 4-1: Graph of Variation of Flow Volume with Time for MW-7B.................... 52

Figure 4-2: Graph of Variation of Flow Volume with Time for MW-8B.................... 52

Figure 4-3: Graph of Variation of Flow Volume with Time for MW-2B, Set One. ....... 53

Figure 4-4: Graph of Variation of Flow Volume with Time for MW-3B, Set One. ....... 53

Figure 4-5: Graph of Variation of Flow Volume with Time for MW-2B, Set Two....... 54

Figure 4-6: Graph of Variation of Flow Volume with Time for MW-3B, Set Two....... 54

Figure 4-7: Graph of Variation of Flow Volume with Time for MW-2B, Set Three..... 55

Figure 4-8: Graph of Variation of Flow Volume with Time for MW-3B, Set Three..... 55

Figure 4-9: Grain Size Distribution Curve for MW-2B......................................... 57

Figure 4-10: Grain Size Distribution Curve for MW-3B............................................. 58

Figure 4-11: Grain Size Distribution Curve for MW-4B....................................... 59

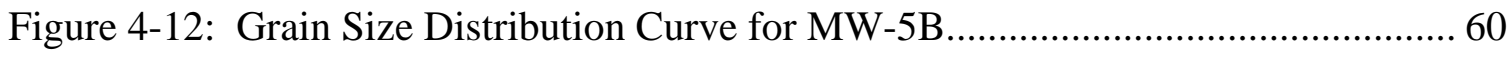

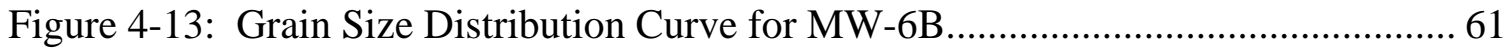

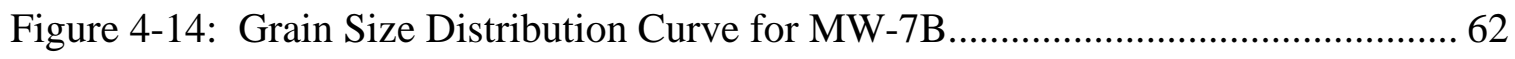

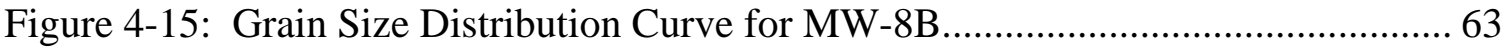


Figure 4-16: Grain Size Distribution Curve for MW-9B................................................. 64

Figure 4-17: Grain Size Distribution Curve for MW-10B............................................. 65

Figure 4-18: Grain Size Distribution Curve for MW-12B............................................ 66

Figure 4-19: Grain Size Distribution Curve for MW-13B............................................... 67

Figure 4-20: Grain Size Distribution Curve for MW-14B.............................................. 68

Figure 4-21: Grain Size Distribution Curve for MW-15B............................................. 69

Figure 4-22: Grain Size Distribution Curve for R-2B.............................................. 70

Figure 4-23: Grain Size Distribution Curve for R-3B................................................. 71

Figure 4-24: Profile of MW-2B with soil description and Atterberg Limits graph......... 76

Figure 4-25: Profile of MW-3B with soil description and Atterberg Limits graph......... 77

Figure 4-26: Profile of MW-4B with soil description and Atterberg Limits graph......... 78

Figure 4-27: Profile of MW-5B with soil description and Atterberg Limits graph......... 79

Figure 4-28: Profile of MW-6B with soil description and Atterberg Limits graph......... 80

Figure 4-29: Profile of MW-7B with soil description and Atterberg Limits graph......... 81

Figure 4-30: Profile of MW-8B with soil description and Atterberg Limits graph......... 82

Figure 4-31: Profile of MW-9B with soil description and Atterberg Limits graph......... 83

Figure 4-32: Profile of MW-10B with soil description and Atterberg Limits graph....... 84

Figure 4-33: Profile of MW-12B with soil description and Atterberg Limits graph....... 85

Figure 4-34: Profile of MW-13B with soil description and Atterberg Limits graph....... 86

Figure 4-35: Profile of MW-14B with soil description and Atterberg Limits graph....... 87

Figure 4-36: Profile of MW-15B with soil description and Atterberg Limits graph....... 88

Figure 4-37: Profile of R-2B with soil description and Atterberg Limits graph. ............ 89

Figure 4-38: Profile of R-3B with soil description and Atterberg Limits graph. ............ 90 
Figure 5-1: Groundwater flow patterns based on the average piezometric surface elevation data in the shallow monitoring wells and the automated recorders (Messenger 2003).

Figure 5-2: Groundwater flow patterns based on the average piezometric surface elevation data in the deep monitoring wells (Messenger 2003).

Figure 5-3: Schematic of Barrier Location using one cell (WVGISTC 2000). 97

Figure 5-4: Schematic of Barrier Location using three cells (WVGISTC 2000). 98

Figure 5-5: Rainfall Data from Recording Well 2 (Messenger 2003). 99

Figure 5-6: Rainfall Data from Recording Well 3 (Messenger 2003). 100

Figure 5-7: Well Reading Data for the Shallow Monitoring Wells, MW-1 - MW-5... 101

Figure 5-8: Well Reading Data for the Shallow Monitoring Wells, MW-6 - MW-10. . 102

Figure 5-9: Well Reading Data for the Shallow Monitoring Wells, MW-11 - MW-15. 103

Figure 5-10: Well Reading Data for the Deep Monitoring Wells. 104

Figure 5-11: Photograph of test pit TP-2, showing strata from ground surface to depth of ten feet. (TS=Top Soil; CL1=Clay Layer 1; SC=Sand-Cobble; CL2=Clay Layer 2) (Fortney 2002). 108

Figure 5-12: Soil Classification of ground surface, using AASHTO and USCS Classification Systems (WVGISTC 2000). 109

Figure 5-13: Soil Classification of site at approximately ten feet below the ground surface, using AASHTO and USCS Classification Systems (WVGISTC 2000)... 110 Figure 5-14: Sloped Trench Wall with Single Layer Hydraulic Barrier Approach....... 113 Figure 5-15: Sloped Trench Wall with Double Layer Hydraulic Barrier Approach. .... 114 
Figure 5-16: Vertical Cutoff Trench Wall with Single Layer Hydraulic Barrier Approach..

Figure 5-17: Vertical Cutoff Trench Wall with Double Layer Hydraulic Barrier

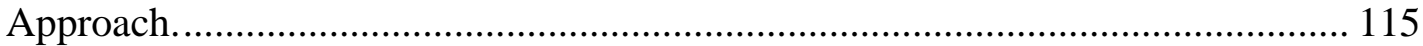




\section{CHAPTER 1: INTRODUCTION}

\subsection{Problem Statement}

The total number of natural wetlands today is nearly half of the amount that was in existence in the United States in the early 1600's. The destruction of wetlands was a common practice performed to make more land available for agricultural expansion and for urban development. Today Federal and State laws prohibit the destruction of natural wetlands without mitigation for unavoidable impacts. As a result of these laws, mitigation of unavoidable impacts affecting natural wetlands has become common. Enforcement of wetland and natural resource protection laws in the United States and elsewhere has led to the common practice of requiring wetlands be created, restored, or enhanced to replace wetlands lost in development such as highway construction, coastal drainage and filling, or commercial development (Mitsch and Gosselink 2000).

Standards for the restoration or creation of wetlands are designed to be the same size of the lost system or often a ratio is implied to ensure more wetlands are created than that destroyed. The ratios used for wetland creation are based upon the quality and productivity of the impacted wetland, for example a natural wetland with poor qualities would likely be mitigated 1:1 as opposed to a natural wetland exhibiting excellent qualities would likely be mitigated $2: 1$ or $3: 1$. The ratio being that for every one acre of surface area impacted, one, two, or three acres will be created. The United States Environmental Protection Agency (USEPA) and the United States Army Corps of Engineers (USACE) govern over the actions that take place in natural wetland areas. 
The state of West Virginia has very few wetlands due to the rugged terrain and the geology of the land. The Appalachian Plateaus Physiographic Province covers nearly the entire state of West Virginia, excluding some areas in the southeastern part of the state. The areas within the Appalachian Plateaus tend to be steep slopes with a high topographic relief, narrow valleys and few alluvial river floodplains (Diehl and Behling 1982). Thus areas within this province are not well suitable for wetland creation or restoration.

The construction of a wetland can be very high in cost due to the amount of excavation needed. A common method involves the ground surface to be excavated down to the seasonal ground water table, causing the area to become saturated. A new method that can be used at the proposed Montrose wetland site would involve the placement of a vertical hydraulic barrier down gradient. The barrier can restrict the flow of the ground water table and cause the water to rise to the top of or just below the surface. This process involves little excavation at the site.

A vertical hydraulic barrier could be used to create an engineered wetland in alluvial filled valleys, generally utilized as agricultural land, in West Virginia. The ground water table in most alluvial filled valleys runs parallel with the low-grade slopes at shallow depths. Thus, the installation of a vertical barrier down gradient could cause the suitable conditions needed for wetland creation. 


\subsection{Benefits of Wetlands}

Wetlands have many different values and functions. These systems are incorporated with water quality and supply, flood protection, erosion control, fish and wildlife habitats, and commercial benefits. The water quality is maintained and improved by wetlands by the removal or transformation of pollutants, through physical, biological, or chemical processes. Wetlands act as buffers, balancing discharge water quality over time and in damping out peaks in potential pollution concentrations (Price and Probert 1997). The removal of nutrients, Biological Oxygen Demand (BOD) from surface water, suspended solids, metals, and pathogens can all be accomplished in a wetland system. Water is also stored in wetlands, acting as a reservoir for the local watershed. This retention of water in wetlands also protects neighboring and downstream properties from flooding. Wetlands located near shorelines and stream banks help protect against erosion. Wetland plants hold the soil in place with their roots, absorb wave energy, and reduce the velocity of stream or river currents (Turner and Gannon 2003).

A wide variety of plant and animal species are dependent upon wetlands for food, habitat, or shelter. These species mostly consist of microbes, insects, amphibians, reptiles, birds, fish, mammals, and a variety of plants. Many threatened and endangered species inhabit wetlands. There is also a commercial market associated with wetlands. Products such as fish, cranberries, timber, and rice can all be extracted from wetlands (Turner and Gannon 2003). Certain medicines may also be derived from wetland soils and plants. Many of the mammals and reptiles that are harvested for their skin are dependent upon wetland habitats. 


\subsection{Objectives}

The goals of this study are:

1. Determine the soil properties at the site.

2. Classify the soil using AASHTO and USCS standards.

3. Determine permeability of the soil.

4. Aid in the creation process for a vertical hydraulic barrier engineered wetland.

The purpose of this project is to determine the geotechnical properties of the proposed Montrose wetland mitigation site. Soil samples from the wetland site were taken and placed in the laboratory for further testing. The soil properties of each sample were determined using standard laboratory testing procedures. Upon completion of soil property testing, the classification of soil using AASHTO and USCS guidelines began. Tests were also run to determine the permeability of the soil at the site. Results from the permeability tests could be used to provide a general location for placement of a hydraulic barrier. 


\section{CHAPTER 2: BACKGROUND}

\section{$2.1 \quad$ Wetlands}

A wetland can be defined as an area characterized by the presence of water at or near the surface, hydric soils, and vegetation adapted to wet conditions. Wetlands perform a wide range of functions that are essential for supporting plant and animal life and for maintaining the quality of the environment. These functions include: flood control; shoreline stabilization; sediment, nutrient, and toxicant retention; and food chain support (Maltby 1991). Wetlands provide unique habitats for a wide variety of flora and fauna. Many endangered species depend upon wetlands for survival and viability.

Wetlands can be found on every continent except Antarctica and in different climates ranging from the tropical to the tundra (Figure 2.1). Based on several estimates, the extent of the world's wetlands is generally thought to be from seven to nine million $\mathrm{km}^{2}$, or about four to six percent of the land surface of the Earth (Mitsch and Gosselink 2000). More than half of the total wetlands in existence today are found in tropical or subtropical regions.

\subsubsection{Wetland Regulations}

At the time of the European settlement, the area that is now the conterminous United States contained an estimated 221 million acres (89.5 million ha) of wetlands. Overtime, wetlands have been drained, dredged, filled, leveled and flooded to the extent that less than half of the original wetland acreage remains (Dahl 1990). Reasons for the destruction of wetlands range from agricultural expansion, urban development, and construction of industrial sites. 


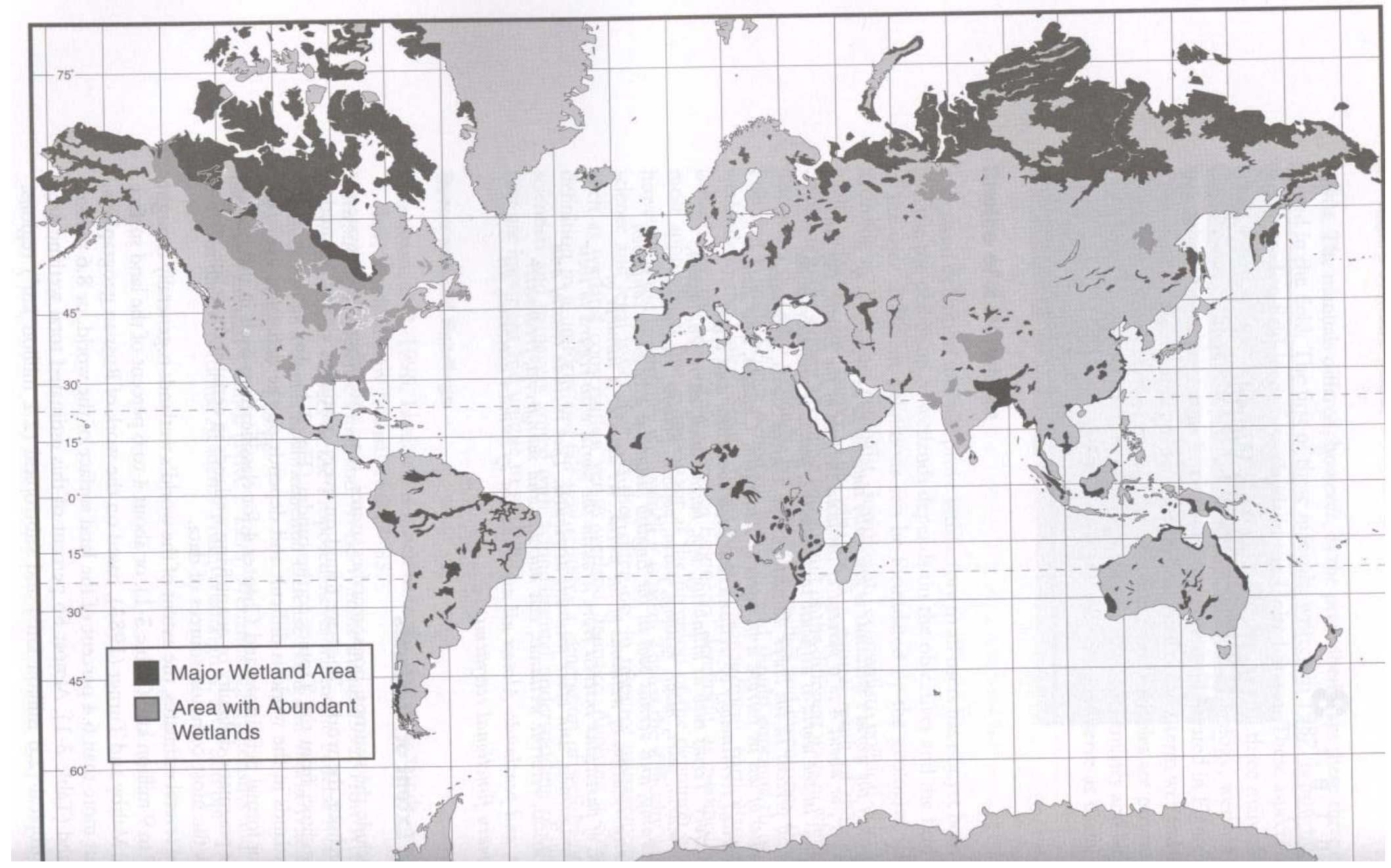

Figure 2-1: Extent of the world's Wetlands (Mitsch and Gosselink 2000). 
In recent years the value of a wetland has become fully understood and society's views about wetlands have changed along with the interest in the preservation of wetlands increasing. Until recent decades, wetlands were generally perceived by the American public as obstacles to development and menaces to the public welfare (Koryak 1982). Congress passed the Swamp Land Acts of 1849, 1850 and 1860, which granted 15 states the rights to 65 million acres of wetlands to control the flooding in the Mississippi River basin. The Act was designed to decrease federal involvement in flood control and drainage by transferring federally owned wetlands to the States, leaving them the iniative of "reclaiming" wetlands through activities such as levee construction and drainage (Mitsch and Gosselink 2000). It wasn't until the early 1970's when interest in protecting wetlands arose and scientists began to identify and quantify the many values of these ecosystems. The use of regulation to protect wetlands as integral and essential parts of the nation's waters began formally in 1972 through the Clean Water Act (also known as the 1972 Federal Water Pollution Control Act). Section 404 of the Clean Water Act establishes the federal authority to regulate activities in wetlands (Turner and Gannon 2003). The increased awareness of how many acres of wetlands have been damaged or destroyed has led to the development of many Federal, State, and local wetland protection programs and laws. No omnibus wetlands protection law exists currently in the United States, thus wetlands are protected through a variety of Federal, State, and local policies, programs, and regulations (Pontius 1990). Table 2.1 shows the chronology of key Federal Legislation and Regulation affecting wetlands. 
Table 2-1: List of Legislation for wetland protection in United States (Turner and Gannon 2003).

\begin{tabular}{|c|c|c|}
\hline YEAR & NAME & DESCRIPTION \\
\hline 1899 & Rivers and Harbors Act of 1899 & $\begin{array}{c}\text { Approval by war secretary required for all construction activities in and } \\
\text { deposition of refuse into navigable water. }\end{array}$ \\
\hline 1867 & $\begin{array}{l}\text { Fish and Wildlife Coordination } \\
\text { Act }\end{array}$ & $\begin{array}{c}\text { Required U.S. Army Corps of Engineers to include ecological effects in their } \\
\text { regulations. }\end{array}$ \\
\hline 1969 & $\begin{array}{l}\text { National Environmental Policy } \\
\text { of } 1969 \text { (NEPA) }\end{array}$ & $\begin{array}{l}\text { Requires the filing of environmental impact statements (EIS) for major } \\
\text { federal activities. }\end{array}$ \\
\hline 1972 & $\begin{array}{l}\text { Federal Water Pollution Control } \\
\text { Act Amendments of } 1972 \text { (Clean } \\
\text { Water Act) }\end{array}$ & $\begin{array}{l}\text { Section } 404 \text { vested authority for wetlands regulations in the USACE and the } \\
\text { USEPA. This refers to the authority to issue permits to discharge dredged } \\
\text { and fill material into waters of the U.S. (Corps) and to veto Corps actions and } \\
\text { policies (EPA). }\end{array}$ \\
\hline 1972 & Coastal Zone Management Act & $\begin{array}{c}\text { Authorized grants for state coastal zone Management program planning and } \\
\text { implementation. }\end{array}$ \\
\hline 1973 & Endangered Species Act & $\begin{array}{l}\text { Required federal agencies to ensure that any actions authorized would not } \\
\text { jeopardize endangered species or threatened species or hurt or destroy their } \\
\text { habitat, including wetlands. }\end{array}$ \\
\hline 1973 & Flood Disaster Protection Act & $\begin{array}{l}\text { Instituted a National Flood Insurance program offering federally subsidized } \\
\text { flood insurance to states and local governments. }\end{array}$ \\
\hline 1977 & $\begin{array}{l}\text { Amendments to Federal Water } \\
\text { Pollution Control Act (Clean } \\
\text { Water Act of 1977) }\end{array}$ & $\begin{array}{l}\text { Exempted from regulation certain farming, forestry, and ranching activities } \\
\text { located in wetlands. }\end{array}$ \\
\hline 1977 & $\begin{array}{l}\text { Executive Order 11988, } \\
\text { Floodplain Management }\end{array}$ & $\begin{array}{c}\text { Required government agencies to avoid activity in and consider impact on } \\
\text { floodplains. }\end{array}$ \\
\hline 1977 & $\begin{array}{l}\text { Executive Order 11990, } \\
\text { Protection of Wetlands }\end{array}$ & $\begin{array}{l}\text { Required government agencies to provide leadership and take action to } \\
\text { minimize the destruction, loss, or degradation of wetlands. }\end{array}$ \\
\hline 1980 & Section 404(b)(1) Guidelines & $\begin{array}{l}\text { Final guidelines issued by EPA for evaluating Section } 404 \text { permit } \\
\text { applications required by Section 404(b)(1) of the Clean Water Act. }\end{array}$ \\
\hline 1985 & $\begin{array}{l}\text { Food Security Act of } 1985 \\
\text { (Farm Bill) }\end{array}$ & $\begin{array}{c}\text { "Swampbuster" provision provided that producers converting wetlands after } \\
12 / 1985 \text { would no longer be eligible for commodity price supports, loans, } \\
\text { crop insurance, and storage payments. }\end{array}$ \\
\hline 1986 & Corps Wetland Regulations & $\begin{array}{l}\text { USACE issued a comprehensive set of regulations on wetlands at } 51 \text { Fed. } \\
\text { Reg. } 41206 \text { (Nov. 13, 1986). }\end{array}$ \\
\hline 1986 & $\begin{array}{c}\text { Emergency Wetlands Resources } \\
\text { Act }\end{array}$ & $\begin{array}{c}\text { Promoted conservation through intensified cooperation among private } \\
\text { interests and government agencies. }\end{array}$ \\
\hline 1986 & Tax Reform Act of 1986 & $\begin{array}{c}\text { Eliminated favorable treatment of capital gains from conversion and restricted } \\
\text { landowners' ability to write off drainage costs, thereby reducing incentives } \\
\text { for the sale or conversion of wetlands }\end{array}$ \\
\hline 1989 & $\begin{array}{l}\text { North American Wetlands } \\
\text { Conservation Act of } 1989\end{array}$ & $\begin{array}{l}\text { Increased protection and restoration of wetlands under the North American } \\
\text { Waterfowl Management Plan. }\end{array}$ \\
\hline 1990 & $\begin{array}{l}\text { Coastal Wetlands Planning, } \\
\text { Protection, and Restoration }\end{array}$ & $\begin{array}{l}\text { Provided cost-share funding for restoration of coastal wetlands and funding } \\
\text { for North American Waterfowl Management Plan projects. }\end{array}$ \\
\hline 1990 & $\begin{array}{l}\text { Food, Agriculture, Conservation } \\
\text { and Trade Act of } 1990\end{array}$ & Established wetlands reserve program for purchase of easements on wetlands. \\
\hline 1990 & $\begin{array}{l}\text { Water Resources Development } \\
\text { Act }\end{array}$ & $\begin{array}{l}\text { Required federal agencies to develop action to achieve no-net loss of } \\
\text { wetlands. }\end{array}$ \\
\hline 1991 & Wetland's Reserve Program & $\begin{array}{l}\text { Program offering landowners the opportunity to receive cost share payments } \\
\text { for restoring wetlands on their property }\end{array}$ \\
\hline 1995 & Executive Order 12962 & Conservation of aquatic systems for recreational fisheries. \\
\hline 1996 & $\begin{array}{c}\text { Federal Agriculture } \\
\text { Improvement and Reform Act }\end{array}$ & $\begin{array}{l}\text { Provides a 7-year framework for the Secretary of Agriculture to administer } \\
\text { agricultural and food programs from } 1996 \text { through } 2002 .\end{array}$ \\
\hline
\end{tabular}


Section 404 requires that that a highway agency create artificial wetlands to compensate for the loss of natural wetlands when they are displaced by construction activity (Shaw et al. 1998). The process to obtain a "404 permit" for dredge-and-fill activity in wetlands is very complex. No discharge of dredged or fill material will be permitted in wetlands if a viable alternative exists. A sequence of approaches is evaluated in the process of issuing a permit:

1. Avoidance - taking steps to avoid wetland impacts where practicable

2. Minimization - minimizing potential impacts in wetlands

3. Mitigation - providing compensation for any remaining, unavoidable impacts through the restoration or creation of wetlands (Mitsch and Gosselink 2000).

The United States Army Corps of Engineers district engineer has the authority to issue a permit. The decision is based upon a number of different considerations, which include conservation, economics, aesthetics, and several other factors (Page and Wilcher 1990). The United States Environmental Protection Agency (EPA), the United States Fish and Wildlife Service, The National Marine Fisheries Service, and state agencies provide assistance to the Corps during the permit process. The EPA has the ability to designate wetlands subject to permits and to veto power on the Corp's decision. In addition to the Army Corp's general guidelines, the EPA has published "Guidelines for Specification of Disposal Sites for Dredged of Fill Material" under section 404 of the "Subpart G, Human Use Characteristics of These Guidelines." The EPA has included sections on recreation, aesthetics, and amenities (Smardon and Karp 1993). 


\subsubsection{Wetland Types and Formations}

There is a wide array of wetland types (Table 2.2) in existence today, ranging from freshwater to salt water wetlands. Wetlands most commonly occur in three topographic and hydrologic situations (Smith and Smith 2001). The first is basin wetlands, which develop in shallow basins ranging from upland topographic depressions to filled in lakes and ponds. The second is riverine wetlands that are developed along shallow and periodically flooded banks of rivers and streams. The third type occurs along the coastal areas of larger lakes and oceans and are known as fringe wetlands. The major difference in distinguishing between the three types is the direction of water flow. In basin wetlands, the water flow is vertical, which consists of precipitation and capillary flow. The water flow in riverine wetlands is unidirectional. In fringe wetlands, the water flow goes in both directions because it involves rising lake levels and tidal action. The flows may bring in and carry away nutrients, and they may physically stress systems by exporting or importing excessive amounts of nutrients and sediments (Smith and Smith 2001). 
Table 2-2: Table of different types of variations of wetlands (Smith and Smith 2001).




There are three geologic factors that affect the formation and presence of wetlands in the north central section of the Appalachian Plateaus province in West Virginia according to Diehl and Behling (1982). The three geologic factors are:

(1) Wetlands may occur in maturely developed stream valleys that are covered by a layer of poorly permeable alluvial material. The stream gradient is usually low and meandering. Structural and lithologic controls play a minor role.

(2) Dipping resistant strata create the possibility for the formation of wetlands upstream from where a stratum crops out within the stream bed. The stream thus becomes ponded and sediment accumulates in the slow moving water. The dipping strata may appear either up or downstream. Breached anticlines and flanks of anticlines that contain wetlands are considered to be a subset of dipping resistant strata setting. The presence of wetlands could be a result of an outcrop of resistant strata in the stream and from limestone in the valley upstream from the resistant strata.

(3) Dissected plateaus that are capped with resistant, flat lying strata are potential sites for the formation of a wetland. The subdued topography of the plateau is eroded until a flat lying resistant lithology is exposed, and wetlands can develop (Diehl and Behling 1982).

Wetlands may also be formed due to man-made activities. The damming or restricting the flow of a stream or a river may cause a wetland to develop. The creating of a depression in the soil in which water may be allowed to accumulate may also cause a wetland to develop. This can be evident in reclaimed mine projects. 


\subsubsection{Wetland Design}

The recognition of wetland values has stimulated the restoration and creation of these ecosystems. The policy of "no net loss" has been adopted by the United States and many other countries (Mueller 2002), which has made wetland creation and/or restoration a veritable industry. Constructed wetlands are becoming increasingly popular for wastewater treatment (Brown 1994). Wetland creation involves the conversion of uplands or shallow open-water systems to vegetated wetlands, whereas returning a wetland to its original or previous state is considered restoration (Mitsch and Gosselink 2000). There are two common methods available for the construction of a wetland (Hayes et al. 2000). Both methods involve the excavation of the substrate to a lower predetermined level. The first method requires grading down to the depth of the ground water table, thus saturating the ground surface. In areas where the seasonal ground water table is relatively deep the second method is commonly used. This process involves the excavation of material to a predisposed level and then the placement of a horizontal barrier. The horizontal barrier creates a water table that will support wetland conditions. This process mainly depends upon precipitation and surface water inflow to create saturated conditions. Both methods described above require excavation across the entire site, which can be very high in cost. A new method that could be implemented is the installation of a vertical hydraulic barrier down gradient.

\subsection{Hydraulic Barriers}

The primary purpose of a hydraulic barrier is to minimize subsurface flow.

Reduction of the subsurface movement of fluids, especially hazardous wastes, has been the subject of much research and considerable controversy over the last few years (Johnson et al. 1985). The controlling factor in minimizing the flow is the hydraulic 
conductivity, $\mathrm{k}$. It is suggested that the hydraulic conductivity be less than $10^{-7} \mathrm{~cm} / \mathrm{s}$. This may be achieved, in clay liners, by controlling the minimum degree of saturation during compaction (Das 1999). Reasons for installing a hydraulic barrier range from preventing hazardous material leaking from a retention installation to installing a hydraulic barrier to implement an engineered wetland (Prakash 1995). Hydraulic barriers are also used as liners and covers of landfills. Designers and installers of irrigation ditches, canals and reservoirs, waste ponds and lagoons, earth dams, mine tailings ponds, excavation dewatering systems, and other types of impoundments are interested in the detention of fluid movement through subsurface media (Johnson et al. 1985).

A major concern in using hydraulic barriers is the integrity of the barrier. The controlling factor with a hydraulic barrier, no matter what the barrier is composed of, is whether it can function satisfactorily over the expected lifespan. The deterioration of a hydraulic barrier resulting in the permeability exceeding the maximum value is definition for a failure.

\subsubsection{Methods}

There are many different ways in which a hydraulic barrier can be implemented. The use of natural materials (gravel, clay or sands), or the use of manmade materials (geosynthetics) can all be an integral part of a hydraulic barrier. Under unsaturated conditions, gravel acts as an effective hydraulic barrier to inflow of water from the surrounding environment and can be used to isolate subsurface disposal facilities (Frind et al. 1976). This use of gravel as a hydraulic barrier is referred to as a capillary barrier or a Richards barrier (Figure 2.2). A Richards barrier consists of a slightly sloped layer of gravel below a layer of finer-grained material such as sand or silt. 


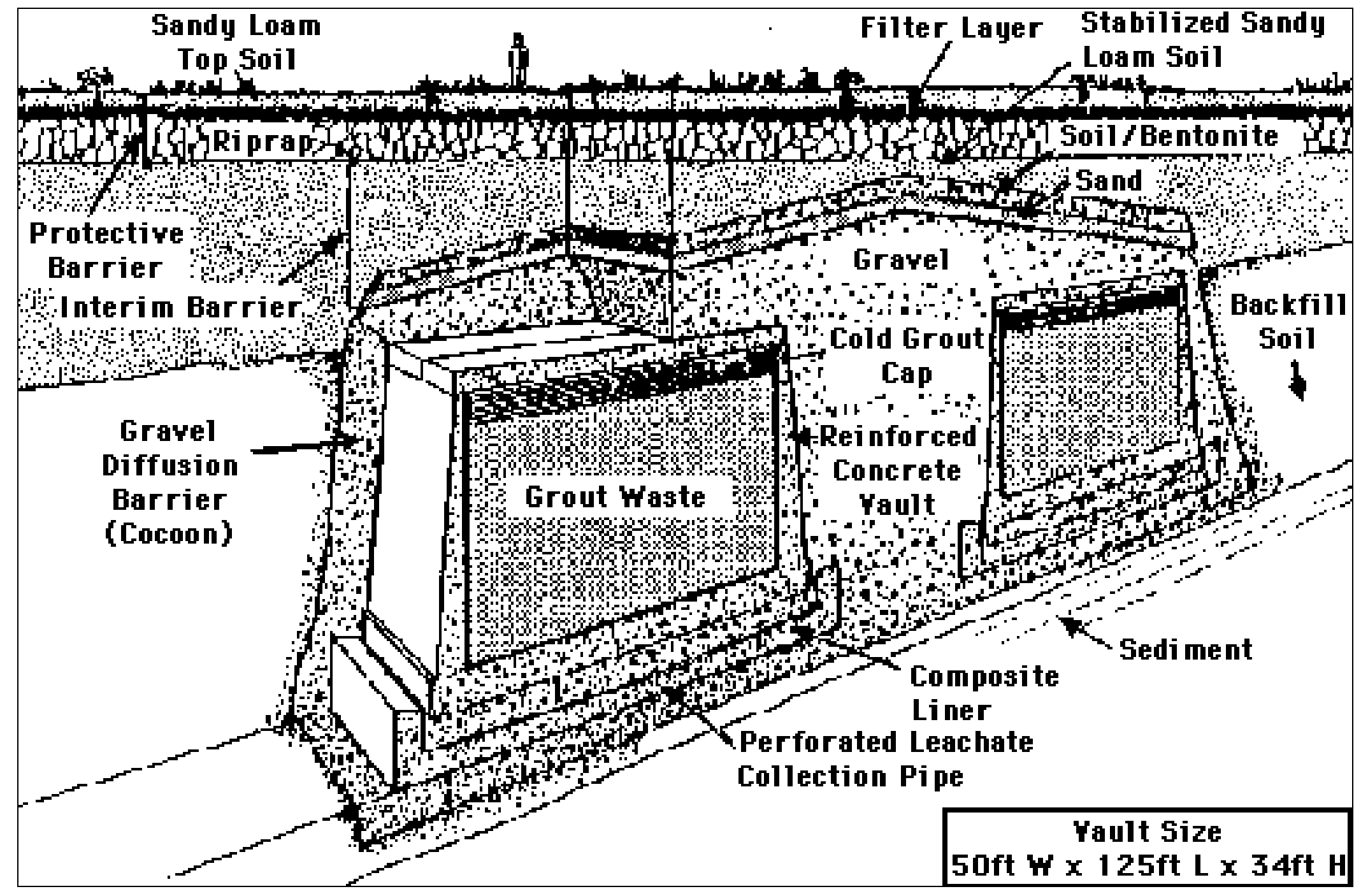

Figure 2-2: Richards Barrier (Frind, Gillham, and Pickens 1976). 


\subsubsection{Slurry Walls}

A slurry wall is a nonstructural wall constructed underground (Figure 2.3). It serves as a vertical barrier to impede the lateral flow of water and other subsurface fluids. There are two main types of slurry walls (Johnson et al. 1985). The first consist of using soil Bentonite (SB) and the second consist of using cement Bentonite (CB). The two types are equally used is engineering projects. Depending upon the project one might have a slight edge over the other and thus be used. The installation process consists of a trench excavated to a horizontal strata of a low permeability material, and then filled with a slurry of either soil Bentonite (SB) or cement Bentonite (CB).

When designing a slurry wall, there are many different factors that are taken into consideration. The length of time of use, either permanent or temporary, should be considered. Another important factor is the loading that the slurry wall will receive. The particle size of the backfill is of another consideration. There are two possibilities, if the soil is too coarse to meet low permeability requirements or if the soil is too fine to meet the necessary strength requirements of the wall. A typical backfill consists of 2-4\% Bentonite by weight of total mixture, $25-35 \%$ water, with the balance being the soil (Johnson et al. 1985).

\subsubsection{Soil Liners}

The incorporation of a properly designed final cover system over a completed landfill (Figure 2.4) is the most effective method for limiting the amount of moisture percolation through waste materials and provides the first line of defense against the generation of significant quantities of leachate from a landfill (Mundell and Bailey 1985). 


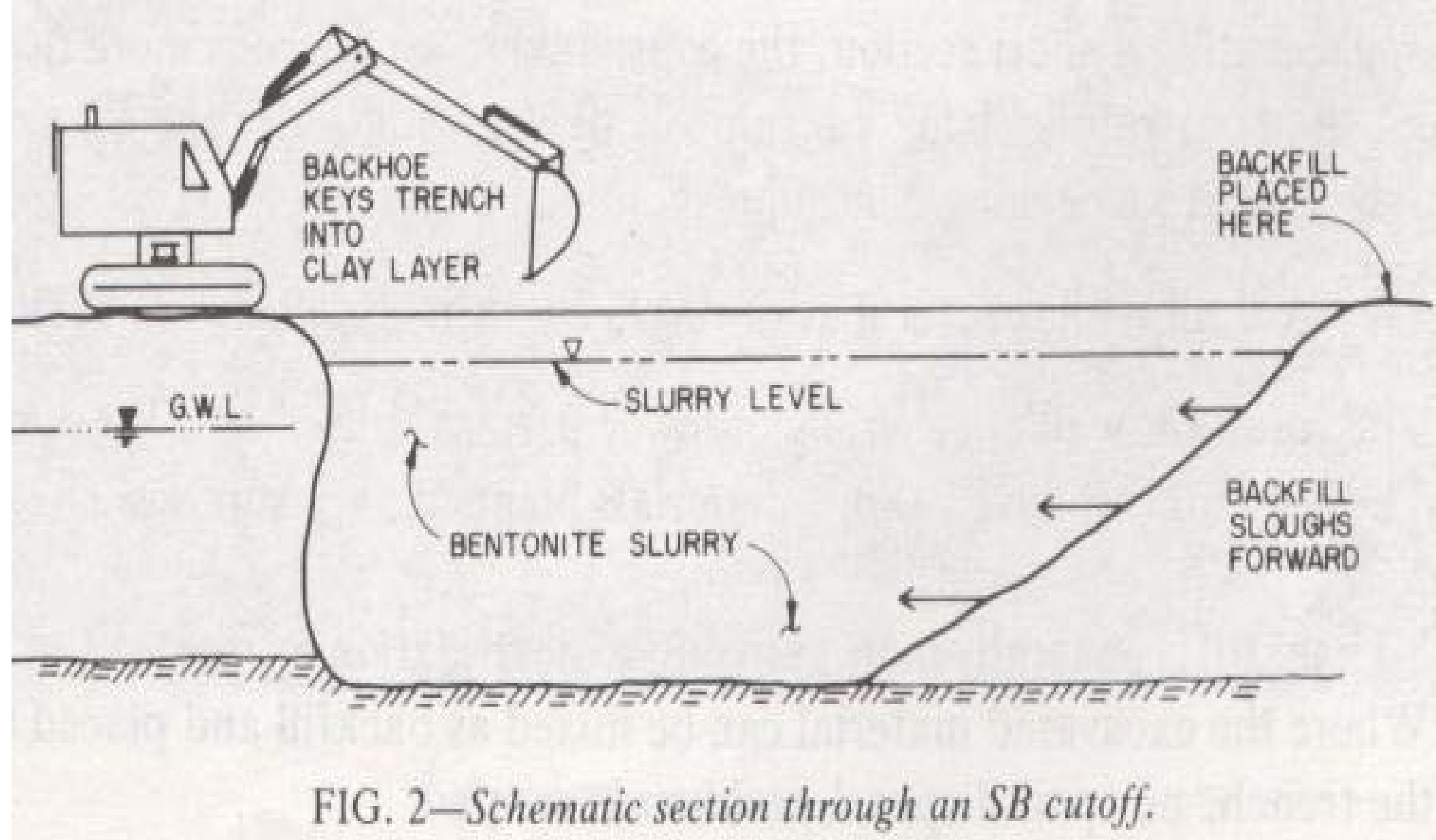

Figure 2-3: Schematic of Slurry Wall Barrier (Johnson et al. 1985). 


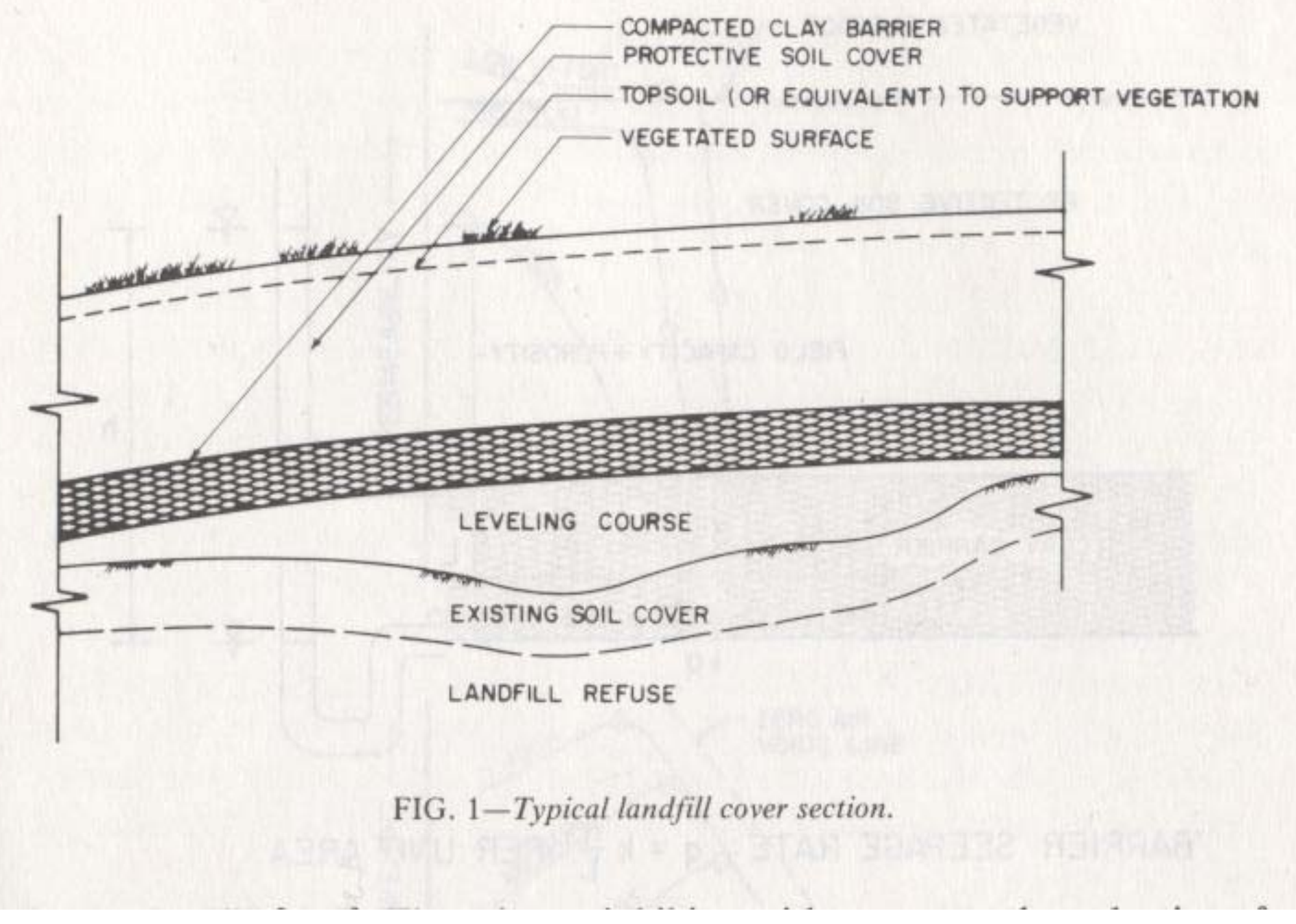

Figure 2-4: Typical landfill cover section (Mundell and Bailey 1985). 
The compacted clay layer will act as an inhibitor to the reduction of percolation through the soil cover. The material lying above the compacted clay layer acts as a shield to protect the layer from any sort of weathering or erosion that may take place over the duration of its use. The leveling layer beneath the compacted clay layer serves to provide a graded work area, firm enough to allow satisfactory compaction of the barrier layer.

There are two major factors to consider when implementing a clay soil liner. The water content and the dry unit weight of the soil must be taken into account. The permeability of soil specimens compacted dry of optimum is generally 10 to 1000 times larger than the permeability of specimens compacted wet of optimum (Mundell and Bailey 1985). As the compaction water content increases, the aggregates decrease in strength and easily undergo large changes during the compaction process, thus resulting in a decrease in the size of aggregate pore space and also causing a decrease in permeability.

To properly control the construction of a compacted clay barrier to achieve permeability values less than that selected as the design permeability, a constant evaluation of the soil layer must be observed. Careful evaluation of the compacted moisture and density conditions of the compacted clay layer must also be monitored. Standard Proctor curves generated from laboratory testing for the various soil types evaluated from the borrow pit can be made available to the design engineer and aid in the compaction criteria necessary to control the permeability of the compacted clay layer. During the placement and compaction of the compacted clay layer, periodic field density tests can be preformed to monitor and maintain control of the compaction process. 


\subsubsection{Sheet Piling}

Sheet piling consists of driving pieces of steel sheets into the ground to impede the subsurface flow (Figure 2.5). The integrity of the barrier depends upon the interlocking of adjacent sheets. If not connected properly leaks can occur causing water to flow through the barrier. One other concern is the installation process. If the substrate consists of large rocks, then when the sheets are driven into the ground they may be torn or snagged on the rocks. A way to alleviate this problem is to excavate a trench, backfill it with sand and then drive in the sheet piles, tying it into an impermeable layer .

Wood and concrete sheet piles have been used in the past, but deterioration over time has limited their usage. New alternative methods such as Fiber Reinforced Plastic Composites (FRPC) and polyvinyl chloride (PVC) have been developed and put into operation as sheet piles.

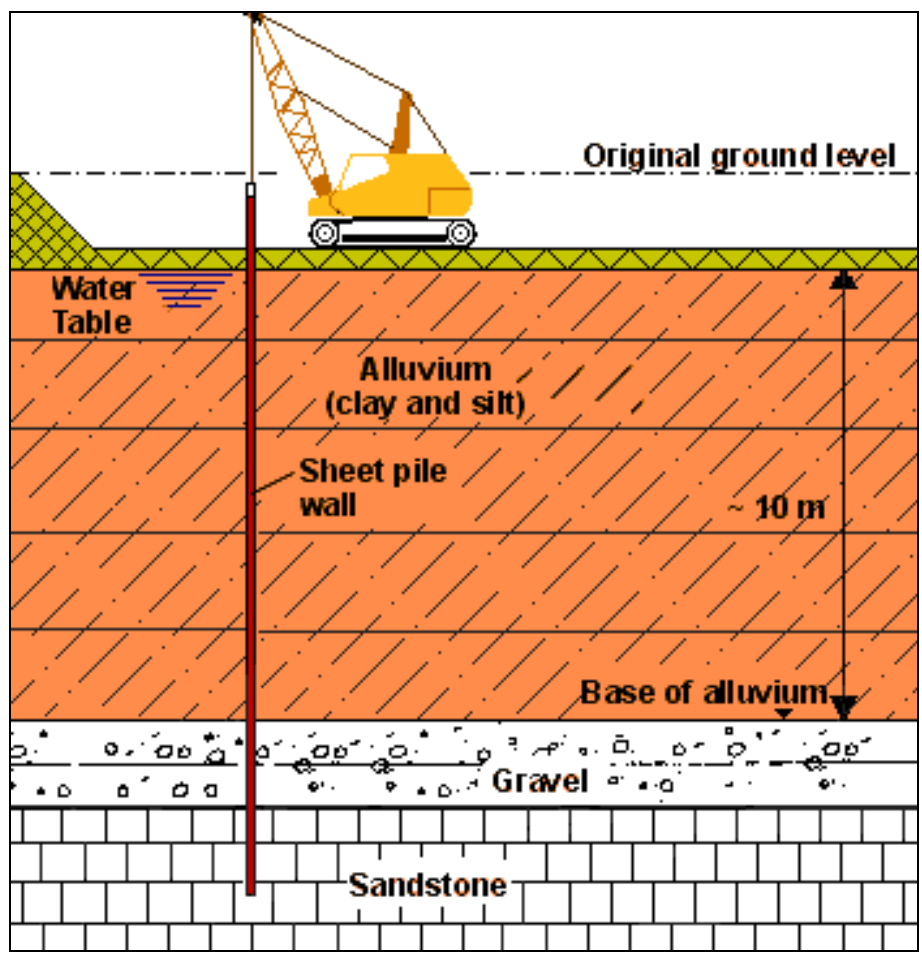

Figure 2-5: Schematic of Sheet Pile Installation (GeoCal 2004). 


\subsubsection{Geomembranes}

Geomembranes are impermeable liquid or vapor barriers usually made from continuous polymeric sheets that are very flexible, but can also be made from the impregnation of geotextiles with asphalt or elastomer sprays (Koerner 1990). The geomembranes are sheets of polymeric material that are manufactured and prefabricated in a factory and transported to the job site, where placement and additional preparations are completed to finalize the job. The geomembranes are made into large rolls for an easy installation process. In order to ensure successful placing of a geosynthetic barrier, the material must be processed carefully during packaging, transporting, handling and installation. Taking any of these processes lightly can cause the material to be torn or punctured and therefore minimize the total effectiveness of the hydraulic barrier.

\subsubsection{Geosynthetic Clay Liner}

Geosynthetic Clay Liners (GCLs) are high performance environmental reinforced composites. The GCL liners consist of two durable geotextile outer layers with a uniform middle layer of sodium Bentonite clay, thus forming a hydraulic barrier (Geosynthetic Clay Liner 2004). Fibers from the non-woven geotextile are needle punched through the layer of Bentonite and incorporated into the other geotextile (either woven or nonwoven). This process results in a strong mechanical bond between the two fabrics.

Geosynthetic clay liners have many advantages over other traditional barrier techniques. The GCL's have a very low hydraulic conductivity and thus are being used more than compacted clay liners, which are very thick and difficult to build (Herlin 2002). A fully hydrated sodium Bentonite layer can have a hydraulic conductivity of approximately one hundred times lower than a typical compacted clay liner (GCL 2004). A characteristic of the Bentonite soil is to swell when hydrated. This causes the GCL to 
seal around any penetrations and gaps on its own. Another advantage of GCL barriers is that there is no effect on the barrier from climatic forces, such as freeze/thaw cycle, or from any differential settlement factors. The climatic forces of the freeze/thaw cycle or the desiccation/rewetting cycle have been found to have no effect on the Bentonite's performance. The high plasticity and self sealing capabilities of the Bentonite avoid any impact from differential settlement. The major component in Bentonite is sodium montmorillonite, which has a high specific surface area, weak interlayer bonds, and a high cation exchange capacity (Lin and Benson 2000).

Installation of a GCL is very fast and easy (Figure 2.6). The GCL's are manufactured in prefabricated rolls and purchase of the material may be done allowing the consumer to buy the exact amount of lineage needed. Placement consists of the excavation of a trench along the desired area for the barrier. The barrier is then rolled out over the trench, tied into an impermeable surface and then backfilled. Geosynthetic clay liners require a soil cover of at least $300 \mathrm{~mm}$ to provide sufficient normal force to confine the expansion of the Bentonite core layer (Mapson 2004). 


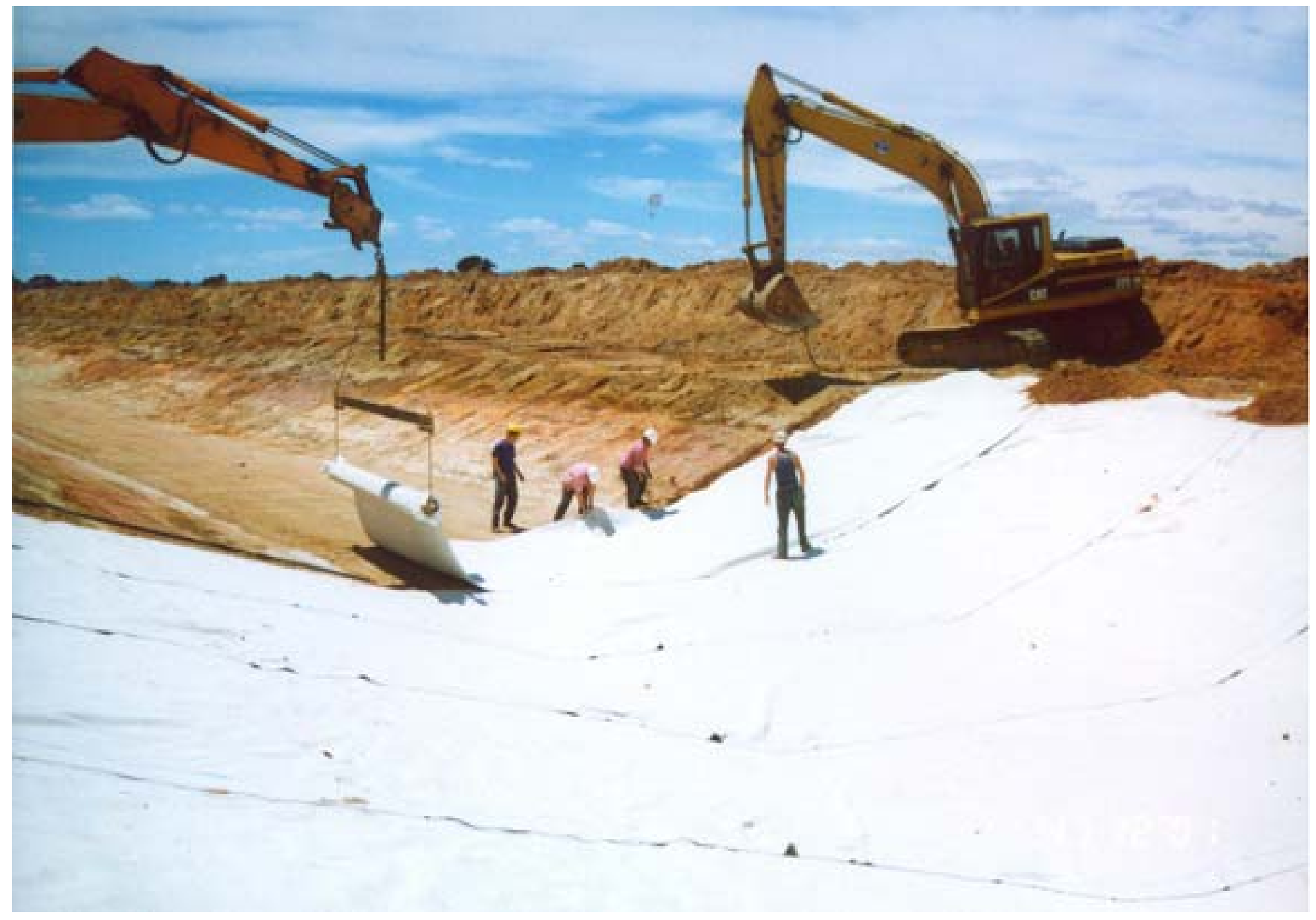

Figure 2-6: Installation process of a Geosynthetic Clay Liner (GCL) (Mapson 2004). 


\section{CHAPTER 3: DESCRIPTION OF FIELD SITE}

\subsection{Montrose Site}

In 2001 the West Virginia Division of Highways (WVDOH) purchased a 34-acre tract of land to develop a mitigated wetland. This site was chosen to implement the use of a vertical barrier as a wetland construction method. The wetland is being constructed as mitigation for unavoidable impacts to natural wetlands within the area due to several WVDOH roadway construction projects.

For the past 50 years this site has been maintained as a hay meadowland (Figure 3.1). Previous owners had installed a network of drainage pipes at a depth of three feet to improve drainage conditions for agricultural use. There are three outlets from the drain field that discharge into Laurel Run (Figure 3.2). There is also a ditch line that enters the $\mathrm{DOH}$ property from the adjacent private property on the southwest corner, crossing the southern edge of the property and exiting at the northeast corner (Fortney 2002).

The site is approximately $21 \mathrm{~km}$ northeast of Elkins, Randolph County, West Virginia (Figure 3.3). The tract of land is bordered on the west by County Route 1, on the north by Laurel Run, and on the south and the east by private property (Figure 3.4). Data from the Soil Survey of Randolph County shows that the soils at the site consist of various types of silt loam. A topographic survey was performed in July of 2001 using a Leica TC600 Electronic Total Station (Messenger 2003). Seven control stations within the site were established and marked with reinforcing steel and labeled CS-1 through CS7 (Figure 3.5). From the data collected from the topographic survey it was determined that the average slope across the site is $-0.0139 \mathrm{~m} / \mathrm{m}$ from west to east. 


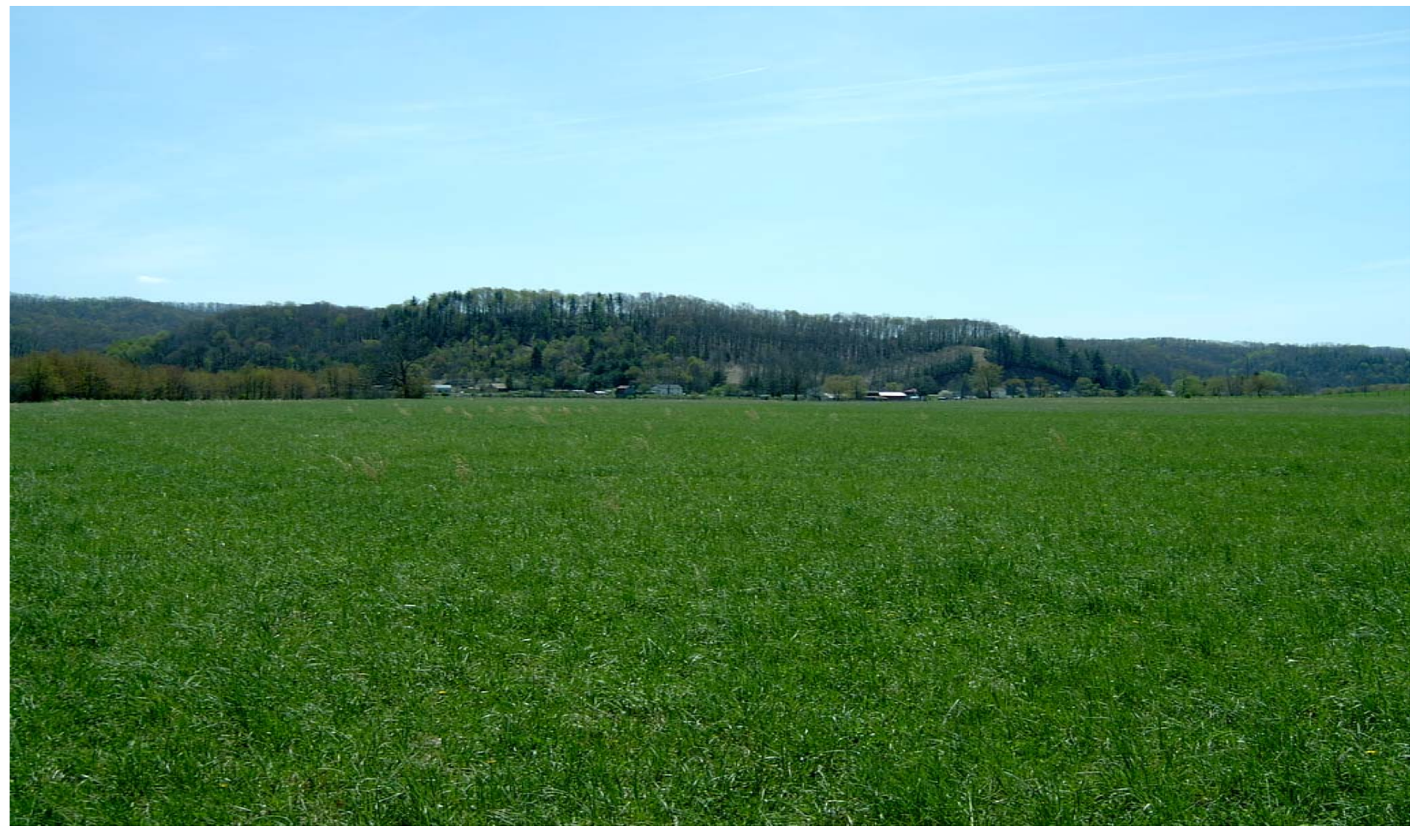

Figure 3-1: Picture of proposed wetland site. 


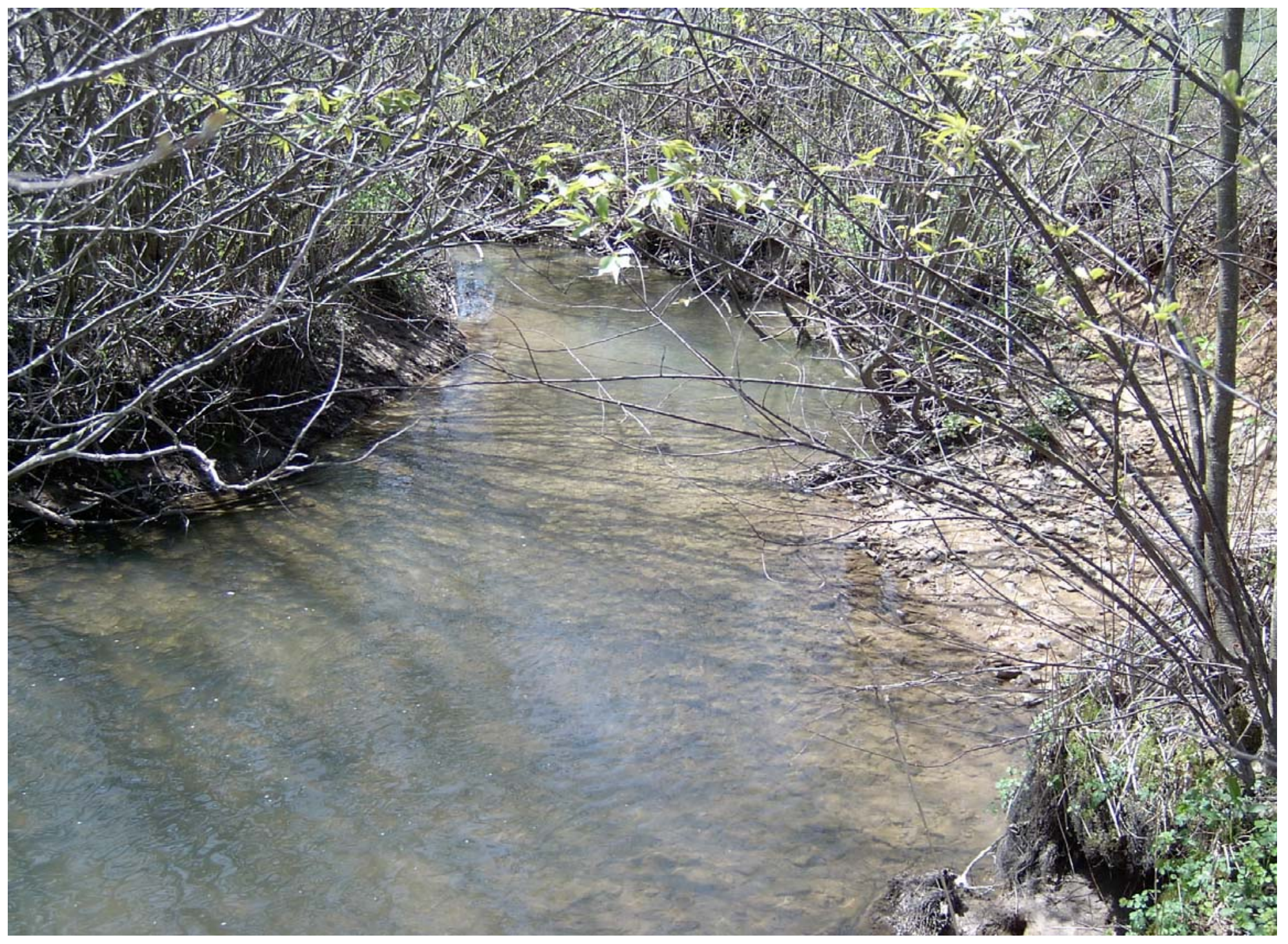

Figure 3-2: Picture of Laurel Run. 


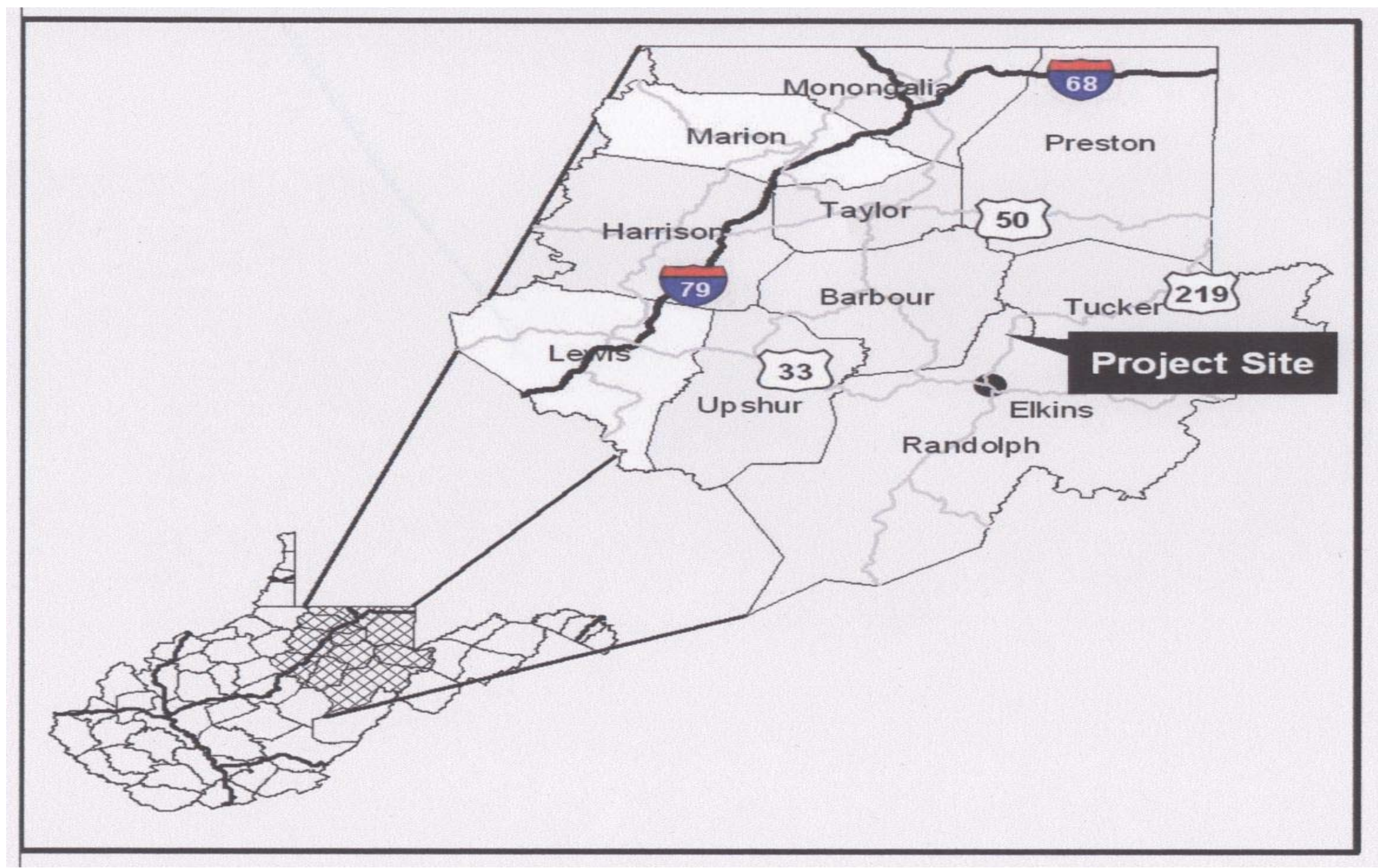

Figure 3-3: Map of North Central West Virginia showing location of project site (Messenger 2003). 


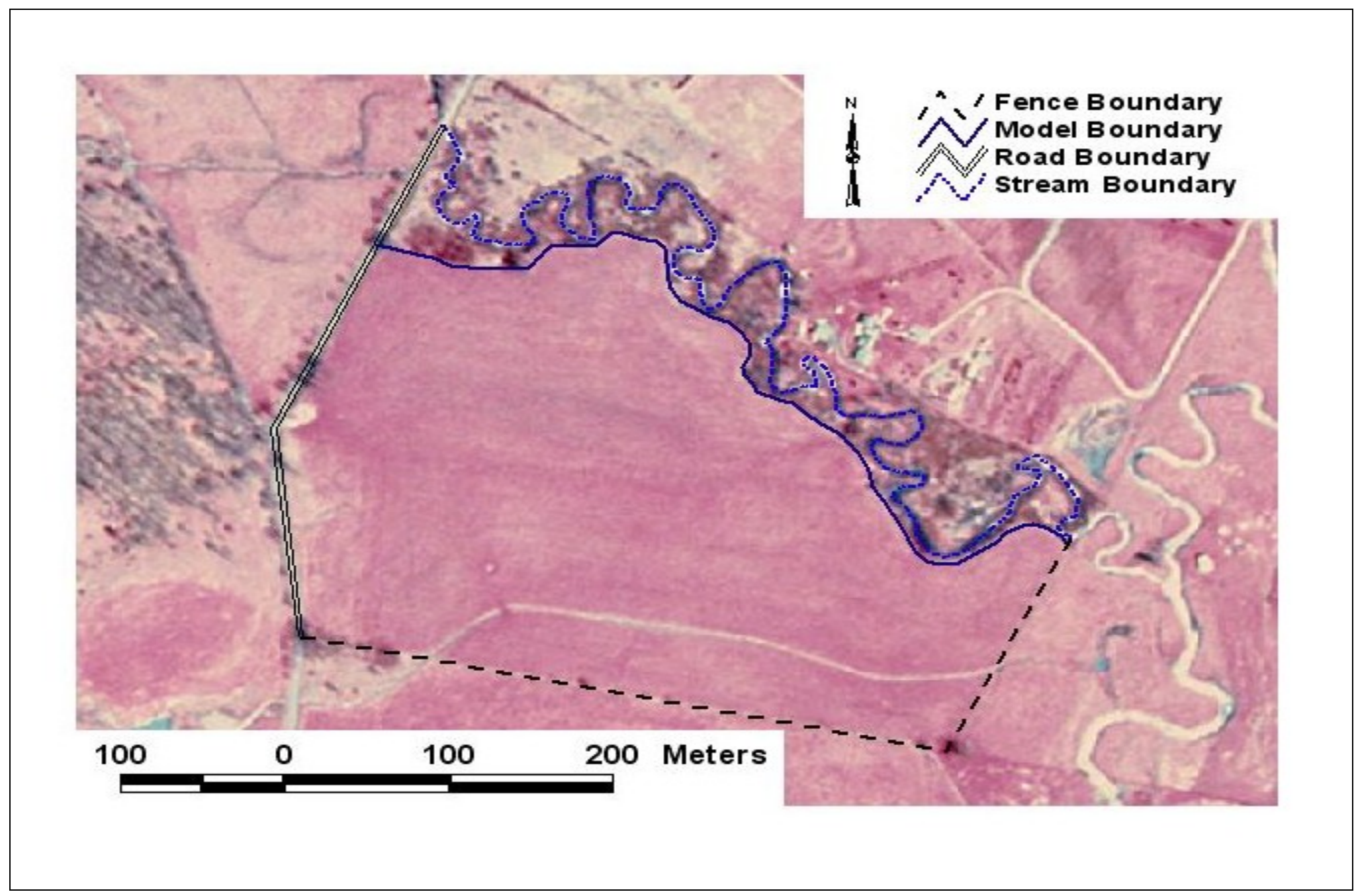

Figure 3-4: Aerial Picture showing boundaries at Montrose Wetland site (WVGISTC 2000). 


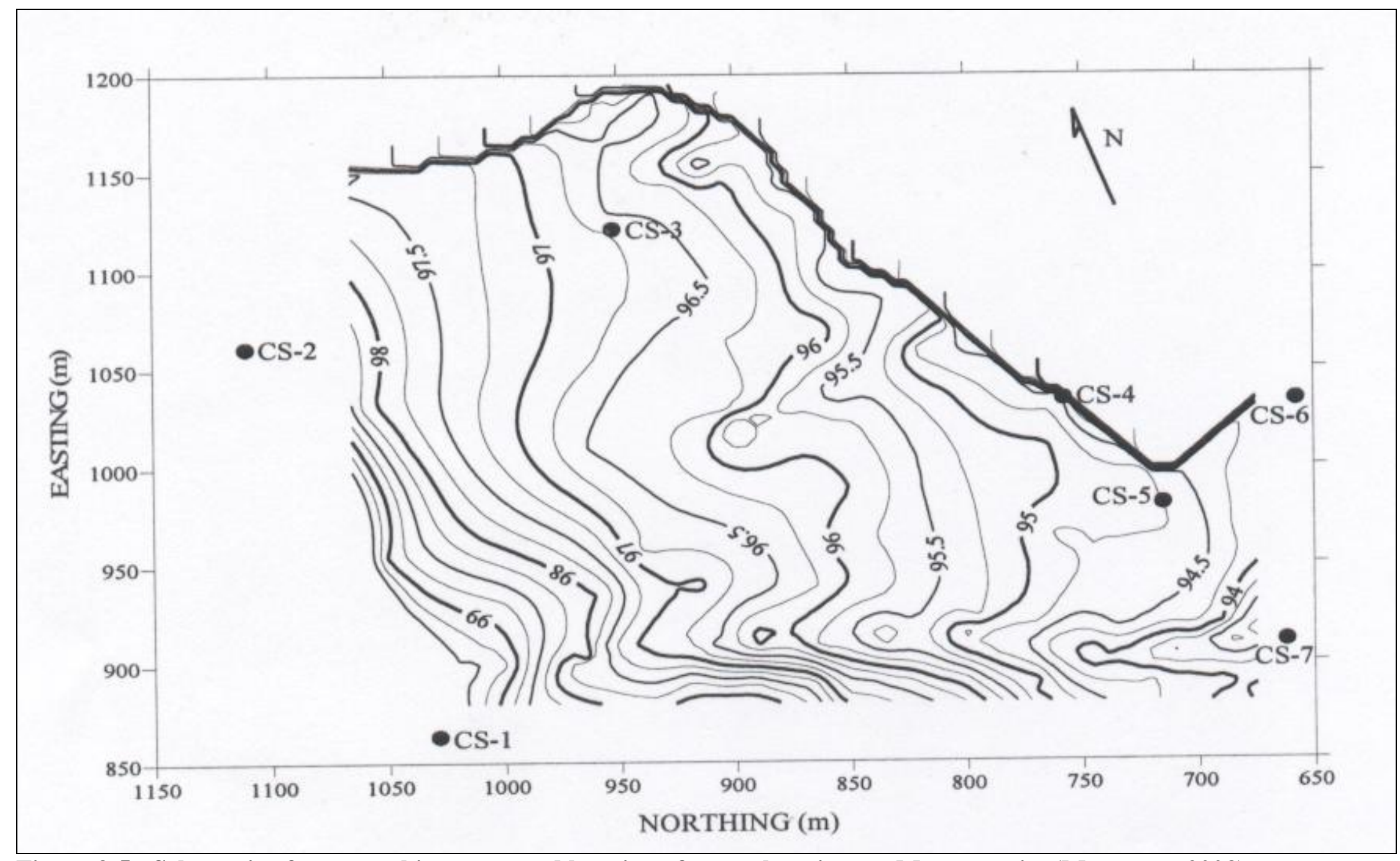

Figure 3-5: Schematic of topographic survey and location of control stations at Montrose site (Messenger 2003). 


\subsection{Soil Selection}

Soil samples from the site were excavated by the WVDOH in the form of test pits and boreholes. Samples were taken to the laboratory to be tested and classified. The geotechnical properties were determined to aid in the placement of the vertical hydraulic barrier.

\subsubsection{Test Pits}

In June of 2002 five test pits were excavated to gather data for a soil profile. Each of the pits revealed similar characteristics and layering: topsoil, clay, shale, and clay (Fortney 2002). A schematic of the soil profile can be seen for TP-1 through TP-4 in Figure 3.6a and for TP-5 in Figure 3.6b. The depths of TP-1 - TP-4 are 3m and the depth of TP-5 is $1.2 \mathrm{~m}$. The location of the five test pits can be seen in Figure 3.7.

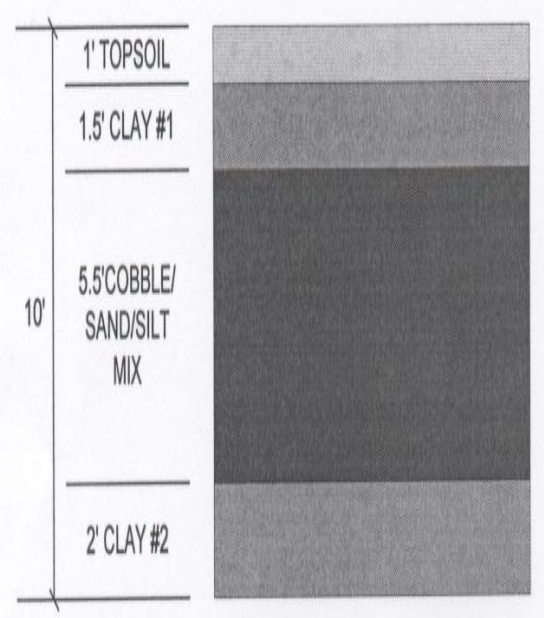

(a)

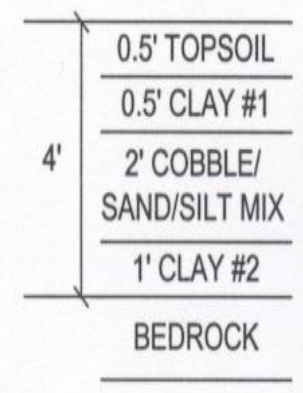

(b)

Figure 3-6: (a) Typical soil profile for TP-1 through TP-4, and (b) Typical soil profile for TP-5 (Fortney 2002). 


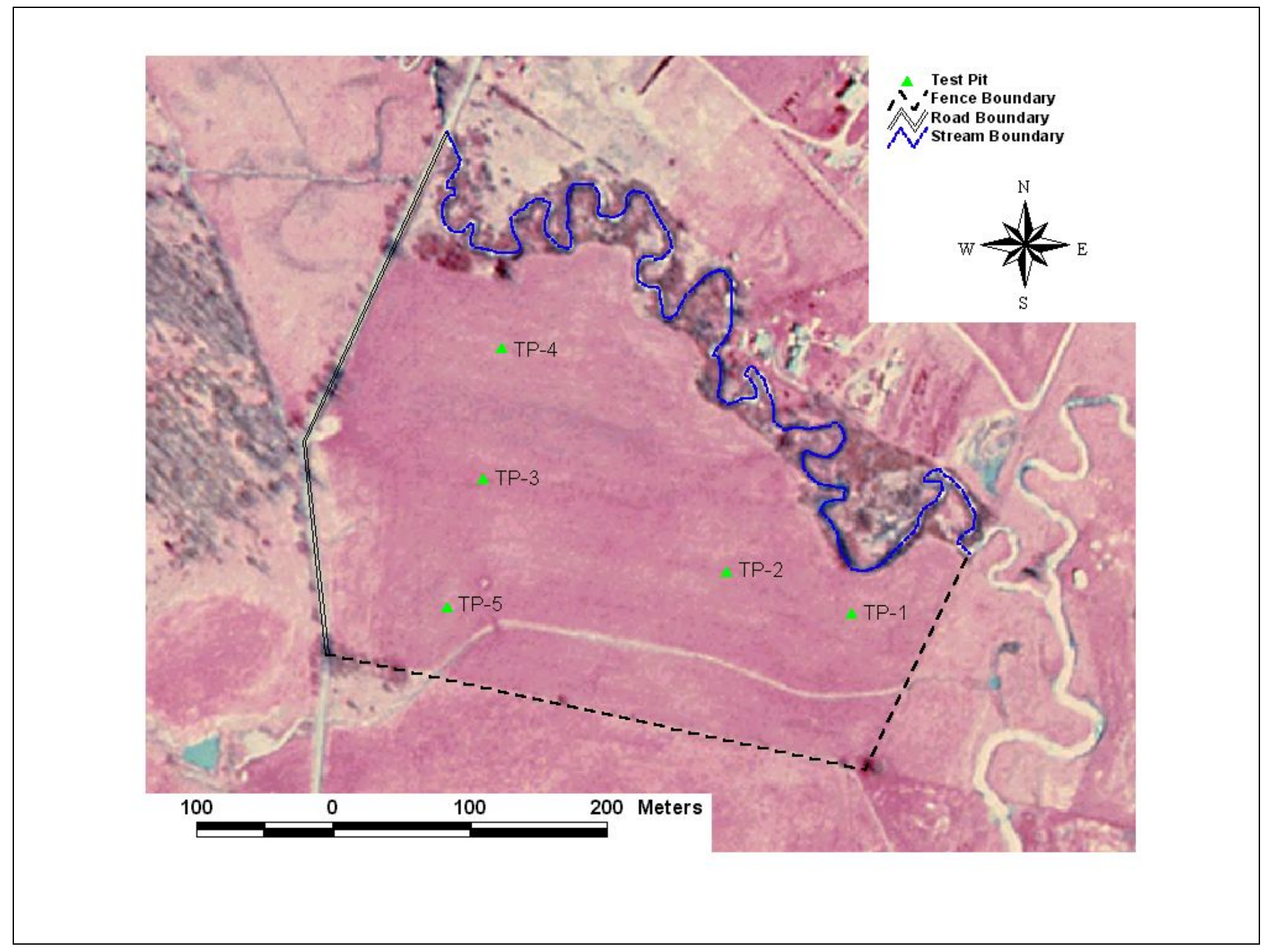

Figure 3-7: Schematic of site showing the five test pits (WVGISTC 2000). 


\subsubsection{Boreholes}

On August $27^{\text {th }}, 2002$, the West Virginia Division of Highways drilling crew began coring samples at the proposed Montrose wetland site. Fifteen boreholes were excavated (Figure 3.8) to collect additional data for the soil profile and two well recorders were installed. A rotary drilling rig (Figure 3.9) was used to cut a borehole through the alluvial material and through the bedrock. An auger was used to remove the alluvial soil and the cobble. A rock-coring bit was used to remove and collect the bedrock material. Split spoon samples were collected continuously at two-foot intervals for each of the observation well boreholes. Five Shelby tube samples were collected from the site. Shelby tube samples were collected from the upper clay layer for MW-3B, MW-4B, and MW-8B, and were collected from the lower clay layer for MW-6B and MW-7B. Disturbed soil samples were also collected from the site using an auger to drill through the alluvial material down to the bedrock. Samples were collected from each distinct layer and placed into gallon-size freezer bags. 


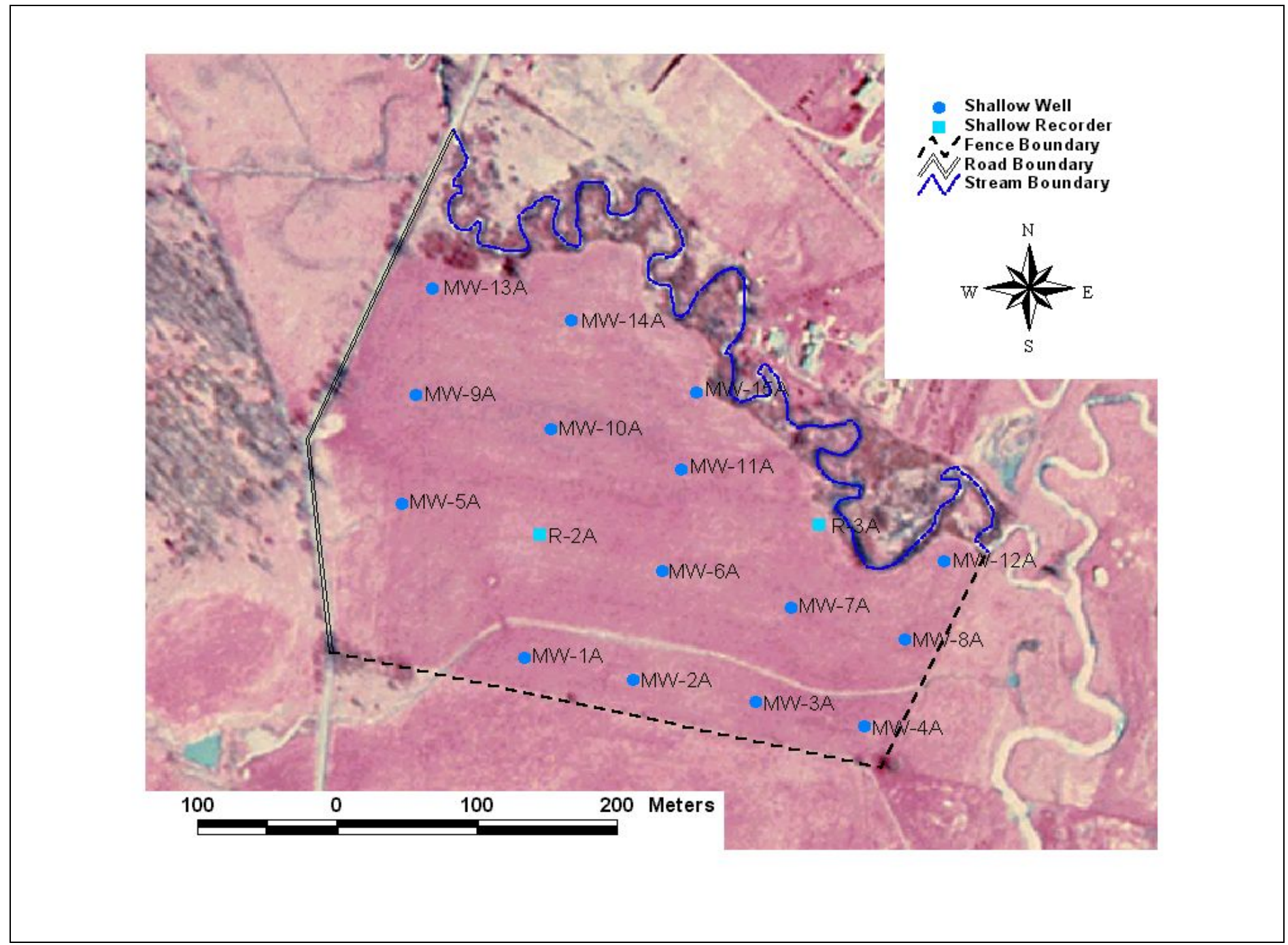

Figure 3-8: Schematic of site showing the 15 boreholes and the 2 recorders (WVGISTC 2000). 




Figure 3-9: Picture of rotary drill used during borehole completion (Messenger 2003). 


\subsection{Piezometric Data}

Shallow monitoring wells at a depth of $1 \mathrm{~m}$ below the surface, deep monitoring wells at a depth of $3 \mathrm{~m}$ to $4 \mathrm{~m}$ below the ground surface, and WL-40 automated recorders were installed to determine the elevation of the piezometric surface. Data from the wells were collected to determine the characteristics of the ground water table. Readings were taken from the shallow and deep monitoring wells monthly.

\subsubsection{Shallow Monitoring Wells}

In January and February 2001, fifteen shallow monitoring wells (Figure 3.10) and two automated water level recorders were installed to record the water level at the Montrose wetland site. Three additional shallow monitoring wells were installed in June 2003 along the banks of Laurel Run. The shallow monitoring wells were constructed of $5 \mathrm{~cm}$ Schedule 40 PVC pipe and contained a 90 $\mathrm{cm}$ screened section at the bottom and a $90 \mathrm{~cm}$ solid section at the top. The location of all wells can be seen in Figure 3.11.

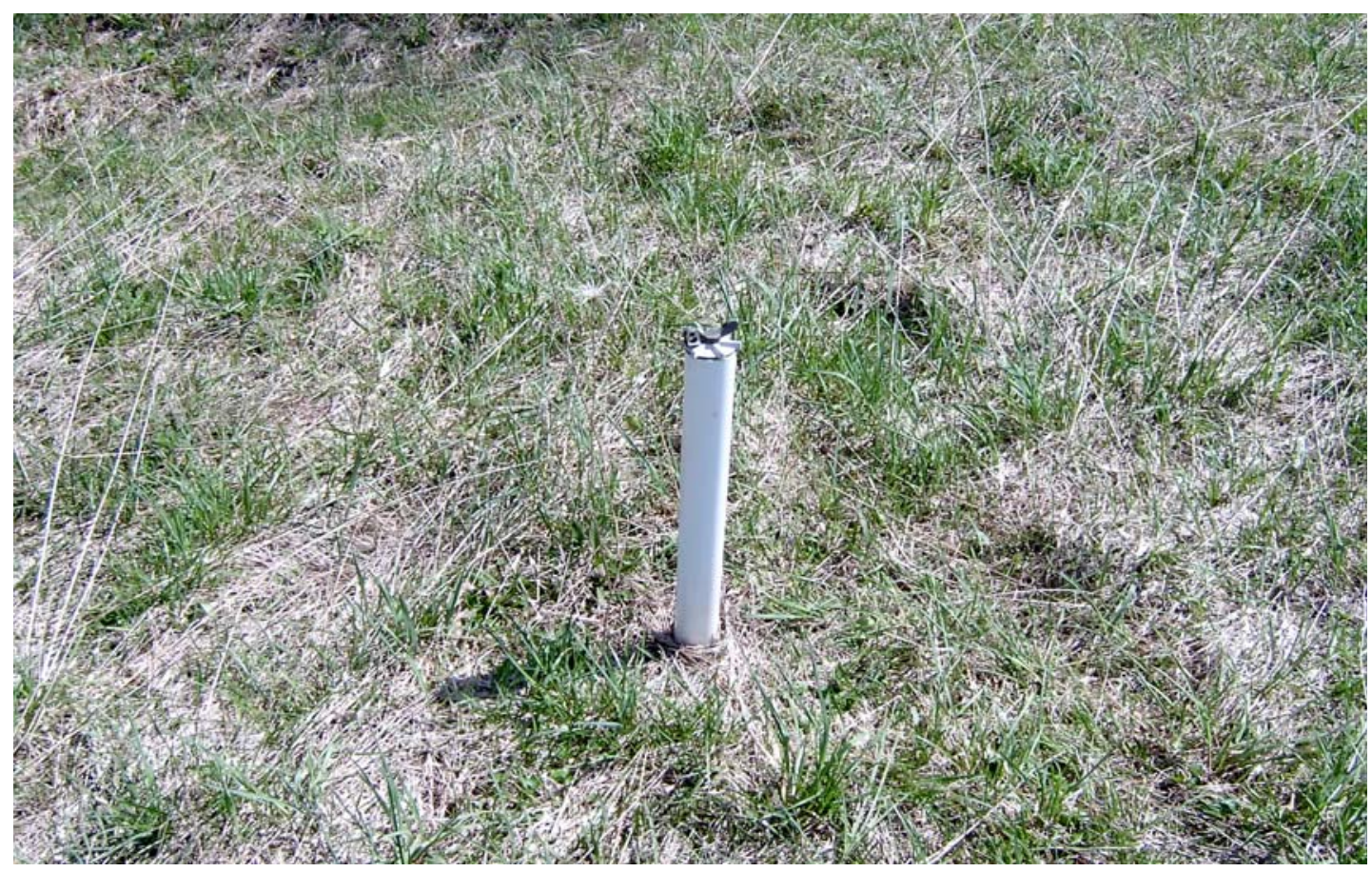

Figure 3-10: Picture of Shallow Monitoring Well at Montrose Wetland Site. 


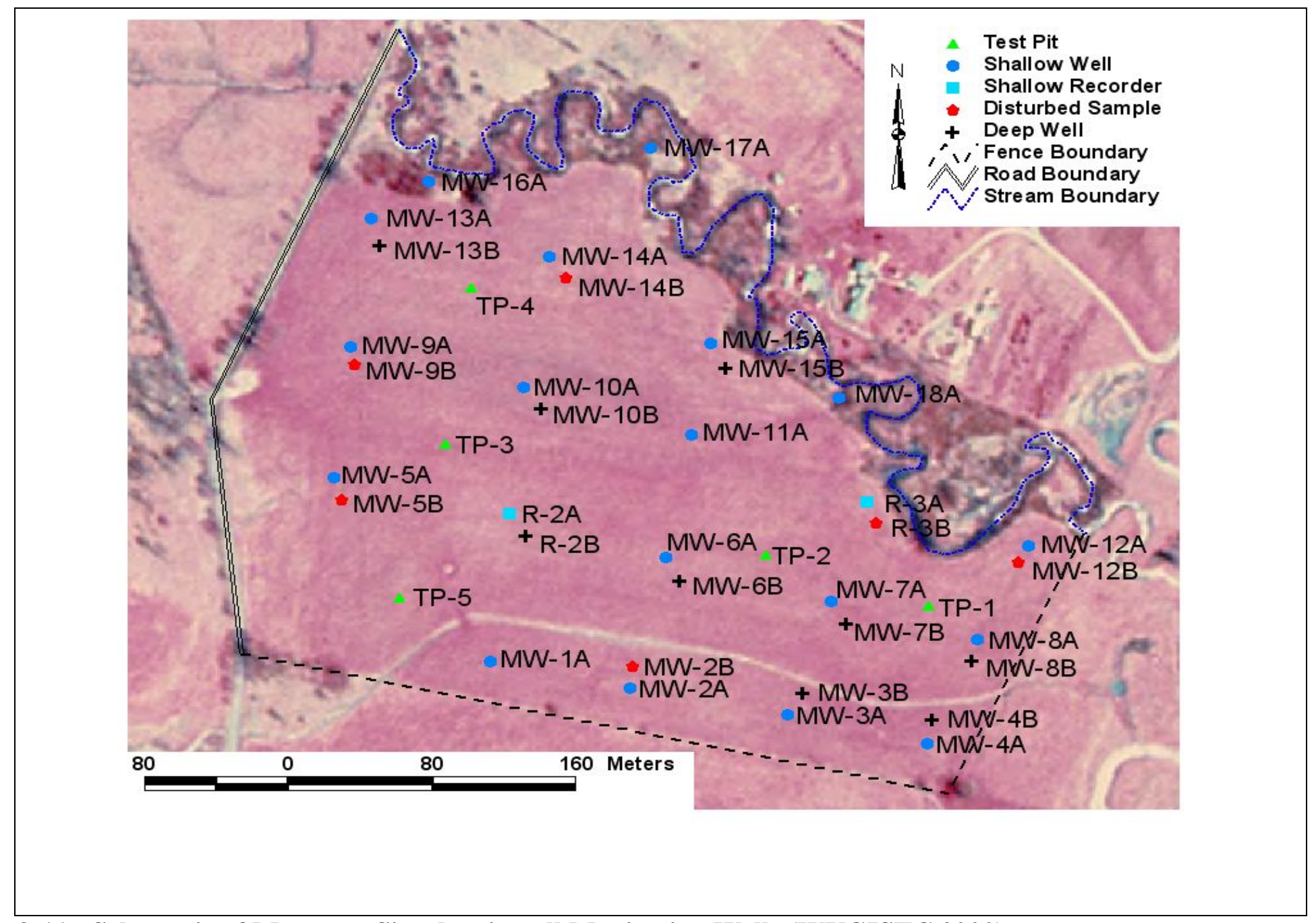

Figure 3-11: Schematic of Montrose Site showing all Monitoring Wells (WVGISTC 2000). 
The installation of these wells consisted of hand auguring a $10 \mathrm{~cm}$ diameter, $120 \mathrm{~cm}$ deep hole. The bottom of the hole was filled with a $10 \mathrm{~cm}$ thick layer of sand. Next the well was placed in the center of the hole and was set in place by pouring in sand around the well, to within $15 \mathrm{~cm}$ of the ground surface. Bentonite was used to fill the hole to the ground surface to prevent any ground water penetrating the hole. Figure 3.12 shows a typical schematic of the shallow monitoring well.

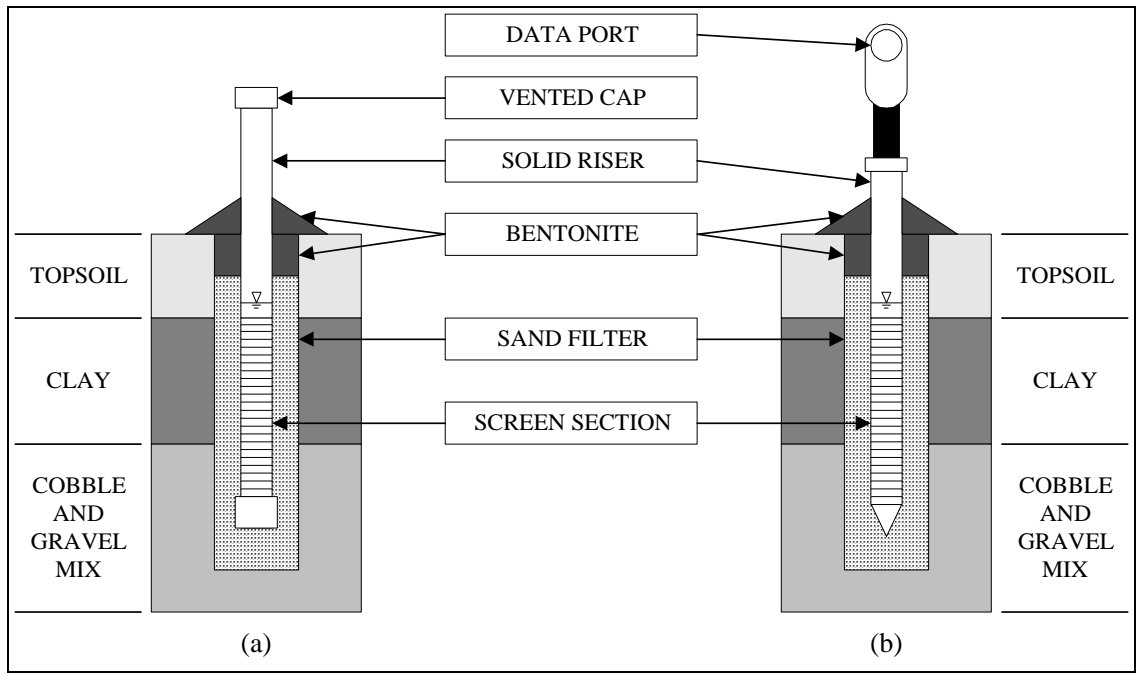

Figure 3-12: Schematic of Monitoring Well Device of: (a) a Shallow Monitoring Well Device and (b) a WL-40 Automated Water Level Recorder (Messenger 2003).

Periodic readings, once a month, were taken from the wells using a 10m Solinst Model 101 Water Level Meter. The distance from the top of the well to the piezometric surface was measured. Obtaining the depth of the ground surface to the piezometric surface was done by subtracting the height of the monitoring well above the ground surface from the measurement. The elevation of the piezometric surface could then be found by subtracting the depth of the ground surface from the ground elevation (Messenger 2003).

The WL-40 automated recorders were installed using the same process as that of the shallow monitoring wells. The piezometric surface was recorded in intervals of 
every 1.5 hours using the recorders. Data was collected from the automated recorders using a Hewlett-Packard HP-48GX calculator. The calculator was linked to the infrared port on the WL-40 recorder to retain data.

\subsubsection{Deep Monitoring Wells}

Nine deep monitoring wells (Figure 3.13) were installed in August 2002 at the Montrose site. These wells were constructed from $3.5 \mathrm{~m}$ sections of $2.5 \mathrm{~cm}$ PVC pipe. Slots were cut into the bottom portion of the wells at a spacing of $2 \mathrm{~cm}$ to $4 \mathrm{~cm}$ apart to create a screen section. Installation for the deep monitoring wells followed that of the shallow wells (Figure 3.14). Readings were taken monthly with the $10 \mathrm{~m}$ Solinst water level reader.

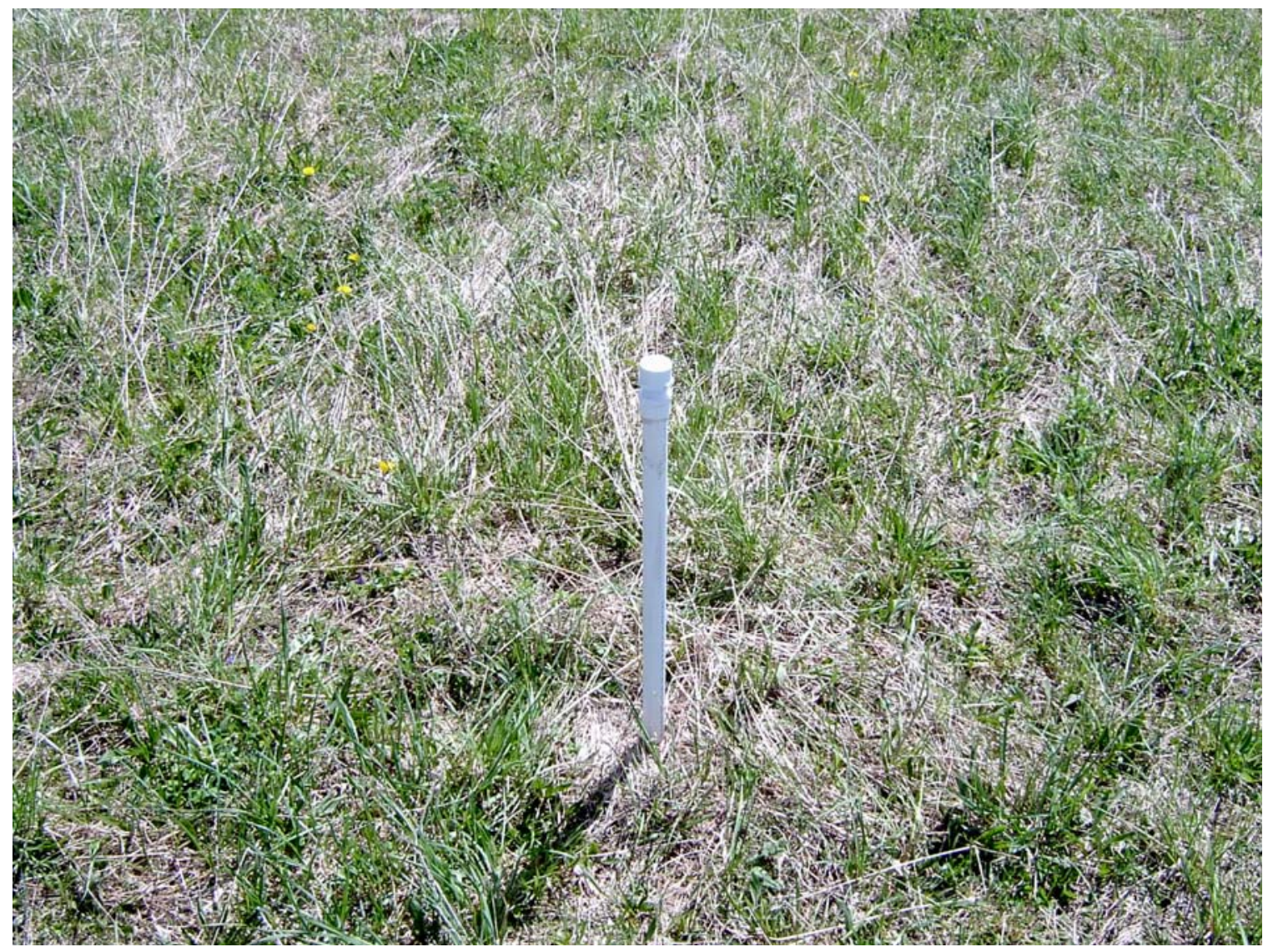

Figure 3-13: Picture of Deep Monitoring Well at Montrose Wetland Site. 


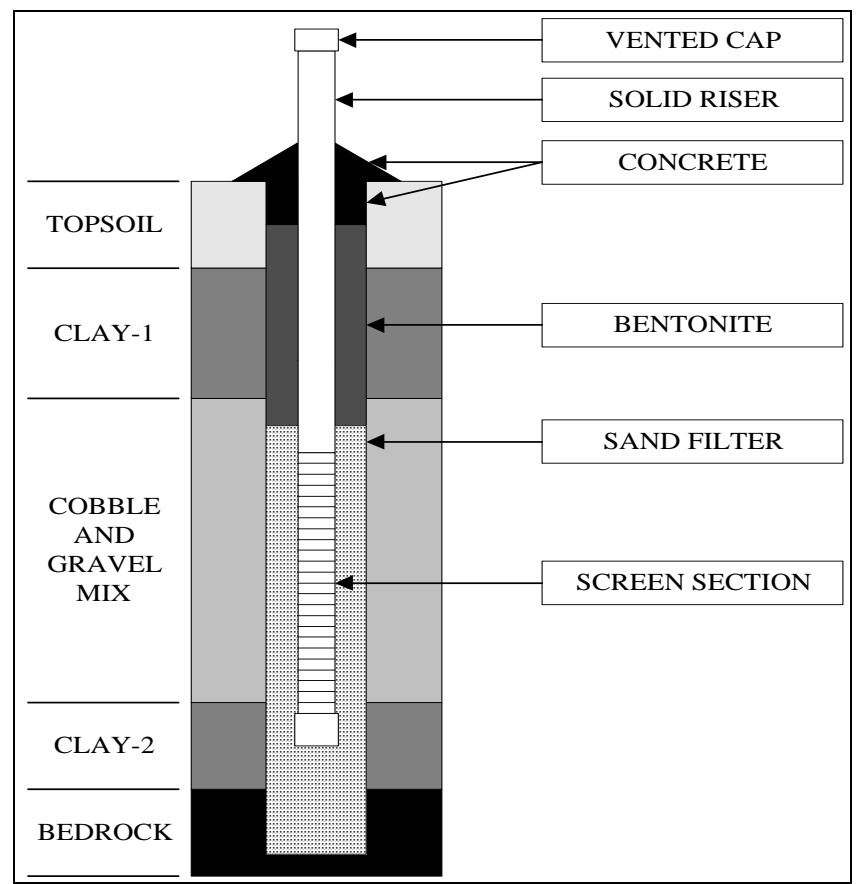

Figure 3-14: Schematic of Deep Monitoring Well Device (Messenger 2003).

\subsection{Test Procedures}

The tests performed for the geotechnical classification of soil are all according to the ASTM and AASHTO standards. A consistent procedure was used for all tests as well as for analyzing the data. The following consists of the procedures and equations used for each laboratory test

\subsubsection{Water Content}

Water content $(\mathrm{w})$ is defined as the mass of water $\left(\mathrm{M}_{\mathrm{w}}\right)$ divided by the mass of solids $\left(\mathrm{M}_{\mathrm{s}}\right)$ and is usually expressed as a percentage:

$$
w=\frac{M_{w}}{M_{s}}(100 \%)
$$


The following equation is used to determine the water content:

$$
w=\left[\frac{\left(M_{i}-M_{f}\right)}{\left(M_{f}-M_{c}\right)}\right](100 \%)
$$

Where;

$\mathrm{Mi}=$ initial mass of container plus moist soil

Mf = final mass of container plus oven-dry soil

$\mathrm{Mc}=$ mass of container

\subsubsection{Atterberg Limits}

The Atterberg limits are widely accepted and can be used for a variety of engineering purposes. Typical uses are for soil classification, earthwork specifications and as an aid in determining the properties of soils.

\subsubsection{Liquid Limit}

The liquid limit is determined after all the water contents have been measured and the points plotted on the flow curve. Draw a straight line of best fit through the points on the on the flow curve and determine the water content corresponding to 25 blows by reading the value off the flow curve. The procedure for the liquid limit test is given by ASTM under designation D-4318 (Das 1998). 


\subsubsection{Plastic Limit}

The plastic limit is determined from the moisture content of the soil at the point at which it crumbles when rolled into threads of $1 / 8^{\prime \prime}$ in diameter. The procedure for the plastic limit test is given by ASTM in Test Designation D-4318 (Das 1998).

\subsubsection{Grain Size}

There are two types of tests performed to determine the grain size of soil. The first is used on coarse-grained soils and it is the sieve analysis. For particles that pass the number 200 sieve (fine-grained) during a sieve analysis, a hydrometer test may be performed to determine particle size.

\subsubsection{Sieve Analysis}

Equation 3-3 is used to calculate the weight of soil retained on each sieve. Once the percent finer for each individual sieve is calculated, a graph of the percent finer by weight versus the sieve size is plotted on semi - log graph paper.

$$
\text { Percent Retained }=\frac{M_{i}}{M_{t}}(100 \%)
$$

\subsubsection{Hydrometer}

Hydrometer tests are based on the sedimentation of soil in water. Results from the hydrometer tests are plotted versus time. Tests were conducted using a standard ASTM $152 \mathrm{H}$ hydrometer. 


\subsubsection{Specific Gravity}

The specific gravity is defined as the ratio of the weight in air of a given volume of soil solids to the weight in air of an equal volume of distilled water of the same temperature. The specific gravity can be calculated using the following formula:

$$
G_{s}=\left[\frac{\left(M_{d}\right)}{\left(M_{1}-M_{2}+M_{d}\right)}\right]
$$

Where;

$\mathrm{M}_{\mathrm{d}}=$ mass of oven dry soil

M1 = mass of water

$\mathrm{M} 2$ = mass of water plus soil

$$
M_{d}=\left[\frac{\left(M_{\text {soil }}\right)}{(1+w)}\right]
$$

\subsubsection{Hydraulic Conductivity}

Hydraulic conductivity tests were performed to determine the permeability of the media. The hydraulic conductivity test performed in the lab was the falling head method. The hydraulic conductivity of the sample can be determined using the following formula:

$$
K=\left[\frac{\left(a_{\text {in }}\right)\left(a_{\text {out }}\right)(L)}{\left((A)(t)\left(a_{\text {in }}+a_{\text {out }}\right)\right)}\right]\left(\ln \left(\frac{h_{1}}{h_{2}}\right)\right)
$$

Where;

$\mathrm{a}_{\mathrm{in}}=$ cross-sectional area of the reservoir containing the influent liquid

$\mathrm{a}_{\text {out }}=$ cross-sectional area of the reservoir containing the effluent liquid

$\mathrm{L}=$ length of the sample

$A=$ cross-sectional area of the specimen 
$\mathrm{t}=$ cumulative elapsed time between determination of $\mathrm{h}_{1}$ and $\mathrm{h}_{2}$

$\mathrm{h}_{1}=$ head loss across the sample at time $\mathrm{t}$

$\mathrm{h}_{2}=$ head loss across the sample at time $\mathrm{t}_{\mathrm{i}}$

\subsubsection{Field Density}

The determination of the density of the site was needed for the reconstruction of samples. The purpose for reconstructing samples was to run hydraulic conductivity tests. The first part of this process consisted in determining the density of Ottawa Sand. This was done using the sand cone method. The density of the sand may be calculated using the following formula:

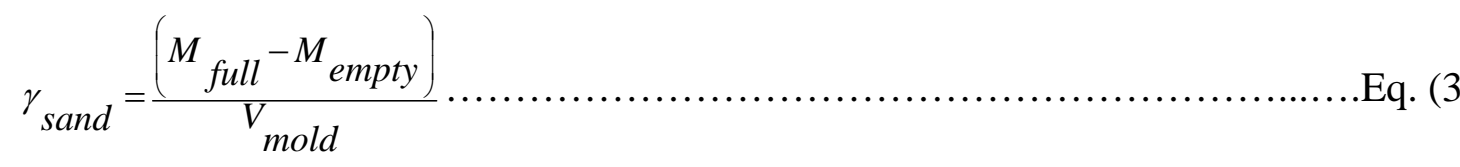

The next step in this process was to determine the density at the site. This procedure has two different steps. The first consisted in determining the density of the material taken from the site as a split spoon sample. The field density can be computed using the following equations:

$$
W_{4}=W_{2}-W_{3}
$$

$$
W_{5}=W_{1}-W_{4}
$$

Where;

$\mathrm{W}_{1}=$ Weight of cylinder and Ottawa sand

$\mathrm{W}_{2}=$ Weight of cylinder, Ottawa sand, and split spoon sample

$\mathrm{W}_{3}=$ Weight of split spoon sample

$\mathrm{W}_{4}=$ Weight of cylinder and Ottawa sand, without sample

$\mathrm{W}_{5}=$ Weight of Ottawa sand displaced 
$\gamma=\frac{W_{1}-W_{c y l}}{V_{c y l}}$

$V_{\text {sample }}=\frac{W_{5}}{\gamma}$

$\gamma_{w_{\text {sample }}}=\frac{W_{3}}{V_{\text {sample }}}\left(\mathrm{g} / \mathrm{cm}^{3}\right)$.

$\gamma_{w_{\text {sample }}}=\left(\gamma_{w_{\text {sample }}}\right)(62.5) \quad\left(\mathrm{lb} / \mathrm{ft}^{3}\right)$

$\gamma_{\text {dry sample }}=\frac{\gamma_{w_{\text {sample }}}}{(1+w)} \quad\left(\mathrm{lb} / \mathrm{ft}^{3}\right)$

The second step consisted of determining the field density at the Montrose wetland site using the sand cone density test. This density was determined for the top surface. The density of the material may be computed using the following formulas:

$$
V_{\text {hole }}=\frac{\left(M_{1}-M_{2}\right)-M_{\text {cone }}}{\gamma_{\text {sand }}}
$$

where,

$$
\begin{aligned}
& M_{\text {cone }}=M_{1}-M_{2}-\left(M_{\text {full }}-M_{\text {empty }}\right) \\
& \gamma_{\text {wet }}=\frac{M_{\text {wet }}}{V_{\text {hole }}}
\end{aligned}
$$




$$
\gamma_{d r y}=\frac{\gamma_{w e t}}{(1+w)}
$$

\subsubsection{Soil Classification}

The classification of the soil at the proposed Montrose mitigated wetland site was performed in accordance with the AASHTO and USCS standards. The AASHTO system of soil classification was developed in 1929 as the Public Road Administration Classification System (Das 1998). The classification system is based upon two soil properties, grain size and plasticity. Results from the sieve grain size analysis tests, using the percent passing the number 10,40, and 200 sieves, are used to classify the soil. The plastic index (PI) is also used as a factor to define a soil's class. The results from the Atterberg limit tests are used to calculate the PI. The plastic index is the liquid limit minus the plastic limit. The AASHTO soil classification system is given in Figure 3.15. $P I=L L-P L$



Figure 3-15: AASHTO Classification Table (Das 1998).

The Unified Soil Classification System is based upon results obtained from the grain size analysis tests. The USCS system was established during World War II. The 
following equations are used in the USCS approach to classify soil. The USCS soil classification system is given in Figure 3.16.

$R_{200}=100-F_{200}$

$R_{4}=100-F_{4}$

Where: $F_{200}=$ Percent Passing Number 200 Sieve.

$\mathrm{F}_{4}=$ Percent Passing Number 4 Sieve.

$C_{u}=$ Uniformity_coefficient $=\frac{D_{60}}{D_{10}}$

$C_{c}=$ Coefficient_of_gradation $=\frac{D^{2}{ }_{30}}{\left(D_{60}\right)\left(D_{10}\right)}$

Where: $\mathrm{D}_{10}=$ Diameter in the particle size distribution curve corresponding to $10 \%$ finer. $\mathrm{D}_{30}=$ Diameter in the particle size distribution curve corresponding to $30 \%$ finer. $\mathrm{D}_{60}=$ Diameter in the particle size distribution curve corresponding to $60 \%$ finer.

\begin{tabular}{|c|c|}
\hline Group symbol & Criteria \\
\hline SW & $\begin{array}{l}\text { Less than } 5 \% \text { passing No. } 200 \text { sieve; } C_{n}=D_{60} / D_{10} \text { greater than or equal to } 6 \text {; } \\
C_{c}=\left(D_{3 n}\right)^{2} /\left(D_{10} \times D_{60}\right) \text { between } 1 \text { and } 3\end{array}$ \\
\hline SP & Less than $5 \%$ passing No. 200 sieve; not meeting both criteria for SW \\
\hline SM & $\begin{array}{l}\text { More than } 12 \% \text { passing No. } 200 \text { sieve; Atterberg limits plot below } A \text {-line (Fig- } \\
\text { ure 3.3) or } P I<4\end{array}$ \\
\hline SC & $\begin{array}{l}\text { More than } 12 \% \text { passing No. } 200 \text { sieve; Atterberg limits plot above A-line (Fig- } \\
\text { ure } 3.3) ; P I>7\end{array}$ \\
\hline SC-SM & $\begin{array}{l}\text { More than } 12 \% \text { passing No. } 200 \text { sieve; Atterberg limits fall in hatched area } \\
\text { marked CL-ML in Figure } 3.3\end{array}$ \\
\hline SW-SM & Percentage passing No. 200 sieve is 5 to 12 ; meets the criteria for SW and SM \\
\hline SW-SC & Percentage passing No. 200 sieve is 5 to 12 ; meets the criteria for SW and SC \\
\hline SP-SM & Percentage passing No. 200 sieve is 5 to 12 ; meets the criteria for SP and SM \\
\hline SP-SC & Percentage passing No. 200 sieve is 5 to 12 ; meets the criteria for SP and SC \\
\hline
\end{tabular}

Figure 3-16: USCS Soil Classification Table (Das 1998). 


\section{CHAPTER 4: RESULTS}

\subsection{Water Content}

Tests were conducted on soil samples taken from the Montrose site to determine the water content of soil. The water content was needed for the process of reconstructing soil samples, for permeability testing. Results from laboratory tests for the water content at the wetland site are shown below. The average water content for the entire site was 20.2\%. Water content graphs plotted versus depth may be found in the appendix D.

Table 4-1: Water Content at each Depth for Montrose Wetland.

\begin{tabular}{|c|c|c|}
\hline Well Location & Depth (ft.) & Water Content \\
\hline \multirow[t]{4}{*}{$M W-2 B$} & $0-1.5$ & 28.30 \\
\hline & $1.5-4.8$ & 31.22 \\
\hline & $4.8-6.2$ & 12.21 \\
\hline & $6.2-9.0$ & 8.00 \\
\hline \multirow{2}{*}{$M W-3 B$} & $1.5-3.5$ & 36.12 \\
\hline & $7.5-9.0$ & 13.44 \\
\hline \multirow{5}{*}{$M W-4 B$} & $1.5-3.5$ & 29.59 \\
\hline & $5.5-7.5$ & 17.63 \\
\hline & $7.5-9.5$ & 17.07 \\
\hline & $9.5-11.5$ & 9.25 \\
\hline & $11.5-13.1$ & 5.36 \\
\hline \multirow[t]{4}{*}{$M W-5 B$} & $0-1.5$ & 32.99 \\
\hline & $1.5-4.2$ & 33.36 \\
\hline & $4.2-5.5$ & 41.69 \\
\hline & $5.5-8.0$ & 12.75 \\
\hline \multirow[t]{5}{*}{$M W-6 B$} & $1.5-3.5$ & 46.22 \\
\hline & $3.5-5.5$ & 10.16 \\
\hline & $5.5-7.5$ & 11.02 \\
\hline & $7.5-9.5$ & 26.69 \\
\hline & $10.5-12.0$ & 8.23 \\
\hline \multirow[t]{4}{*}{ MW-7B } & $1.5-3.5$ & 12.52 \\
\hline & $3.5-5.5$ & 25.04 \\
\hline & $5.5-7.5$ & 28.04 \\
\hline & $10.5-11.1$ & 17.13 \\
\hline \multirow[t]{5}{*}{ MW-8B } & $1.5-3.5$ & 14.19 \\
\hline & $3.5-5.5$ & 15.85 \\
\hline & $5.5-7.5$ & 14.84 \\
\hline & $8.8-10.8$ & 12.70 \\
\hline & $10.8-12.0$ & 10.85 \\
\hline \multirow[t]{4}{*}{ MW-9B } & $0-1.5$ & 38.27 \\
\hline & $1.5-4.5$ & 43.49 \\
\hline & $4.5-8.8$ & 23.26 \\
\hline & $8.8-10.7$ & 14.83 \\
\hline
\end{tabular}

\begin{tabular}{|c|c|c|}
\hline Well Location & Depth (ft.) & Water Content \\
\hline \multirow[t]{5}{*}{ MW-10B } & $1.5-3.5$ & 39.76 \\
\hline & $3.5-5.5$ & 11.32 \\
\hline & $5.5-7.5$ & 12.38 \\
\hline & $7.5-9.5$ & 12.34 \\
\hline & $9.5-11.2$ & 12.49 \\
\hline \multirow[t]{4}{*}{$\mathrm{MW}-12 \mathrm{~B}$} & $0-1.5$ & 21.42 \\
\hline & $1.5-3.8$ & 19.53 \\
\hline & $3.8-9.8$ & 10.64 \\
\hline & $9.8-10.5$ & 6.46 \\
\hline \multirow[t]{7}{*}{ MW-13B } & $1.5-3.5$ & 32.81 \\
\hline & $3.5-5.5$ & 11.04 \\
\hline & $5.5-7.5$ & 7.21 \\
\hline & $7.5-9.5$ & 9.73 \\
\hline & $9.5-11.5$ & 10.53 \\
\hline & $11.5-13.5$ & 10.25 \\
\hline & $13.5-14.3$ & 3.01 \\
\hline \multirow[t]{5}{*}{ MW-14B } & $0-1.5$ & 26.20 \\
\hline & $1.5-2.9$ & 29.35 \\
\hline & $2.9-5.5$ & 17.07 \\
\hline & $5.5-10.1$ & 21.66 \\
\hline & $10.1-13.5$ & 14.27 \\
\hline \multirow[t]{6}{*}{ MW-15B } & $1.5-3.5$ & 25.96 \\
\hline & $3.5-5.5$ & 12.36 \\
\hline & $5.5-7.5$ & 11.48 \\
\hline & $7.5-9.5$ & 8.11 \\
\hline & $9.5-11.5$ & 21.47 \\
\hline & $11.5-12.1$ & 8.76 \\
\hline \multirow[t]{3}{*}{$\mathrm{R}-2 \mathrm{~B}$} & $1.5-3.5$ & 26.36 \\
\hline & $3.5-5.5$ & 14.79 \\
\hline & $5.5-6.2$ & 10.48 \\
\hline \multirow[t]{4}{*}{$\mathrm{R}-3 \mathrm{~B}$} & $0-1.5$ & 25.62 \\
\hline & $1.5-4.0$ & 23.78 \\
\hline & $4.0-7.0$ & 17.31 \\
\hline & $7.0-10.5$ & 49.80 \\
\hline
\end{tabular}


Table 4-2: Average Water Content for Montrose Wetland Site.

\begin{tabular}{|l|c|c|}
\cline { 3 - 3 } \multicolumn{2}{c|}{} & Water Content \\
\hline Monitoring Well: & 2B & 19.93 \\
\hline Monitoring Well: & 3B & 24.78 \\
\hline Monitoring Well: & 4B & 15.78 \\
\hline Monitoring Well: & 5B & 30.20 \\
\hline Monitoring Well: & 6B & 20.46 \\
\hline Monitoring Well: & 7B & 20.68 \\
\hline Monitoring Well: & 8B & 13.68 \\
\hline Monitoring Well: & 9B & 29.96 \\
\hline Monitoring Well: & 10B & 17.66 \\
\hline Monitoring Well: & 12B & 14.51 \\
\hline Monitoring Well: & 13B & 12.08 \\
\hline Monitoring Well: & 14B & 21.71 \\
\hline Monitoring Well: & 15B & 14.69 \\
\hline Recording Well: & 2B & 17.21 \\
\hline Recording Well: & 3B & 29.13 \\
\hline
\end{tabular}

Average Water Content:

20.16

\subsection{Atterberg Limits}

Testing for the Atterberg Limits consisted of determining the liquid limit and the plastic limit of each soil sample obtained. Results from these tests were needed to aid in the classification process. Typical results are shown below.

Table 4-3: Atterberg Limits for Each Depth at Montrose Site.

\begin{tabular}{|c|c|c|c|}
\hline Well Location & Depth (ft.) & Liquid Limit & Plastic Limit \\
\hline MW-2B & $0-1.5$ & 35.01 & 27.75 \\
\hline & $1.5-4.8$ & 28.12 & 19.73 \\
\hline & $4.8-6.2$ & 27.74 & 21.21 \\
\hline & $6.2-9.0$ & 37.72 & 25.56 \\
\hline MW-3B & $1.5-3.5$ & 23.00 & 14.46 \\
\hline & $7.5-9.0$ & 20.33 & 16.20 \\
\hline MW-4B & $1.5-3.5$ & 26.69 & 21.25 \\
\hline & $5.5-7.5$ & 20.55 & 16.28 \\
\hline
\end{tabular}




\begin{tabular}{|c|c|c|c|}
\hline & $7.5-9.5$ & 19.44 & 15.50 \\
\hline & $9.5-11.5$ & 23.36 & 18.78 \\
\hline & $11.5-13.1$ & 28.59 & 22.44 \\
\hline \multirow[t]{4}{*}{ MW-5B } & $0-1.5$ & 38.82 & 28.24 \\
\hline & $1.5-4.2$ & 42.37 & 27.88 \\
\hline & $4.2-5.5$ & 53.30 & 34.12 \\
\hline & $5.5-8.0$ & 41.26 & 27.76 \\
\hline \multirow[t]{5}{*}{ MW-6B } & $1.5-3.5$ & 33.08 & 24.31 \\
\hline & $3.5-5.5$ & 20.87 & 14.76 \\
\hline & $5.5-7.5$ & 23.03 & 17.89 \\
\hline & $7.5-9.5$ & 41.37 & 26.23 \\
\hline & $10.5-12.0$ & 23.58 & 15.35 \\
\hline \multirow[t]{5}{*}{ MW-7B } & $1.5-3.5$ & 24.24 & 18.69 \\
\hline & $3.5-5.5$ & 23.58 & 16.03 \\
\hline & $5.5-7.5$ & 28.82 & 21.01 \\
\hline & $9.5-10.5$ & 26.78 & 19.60 \\
\hline & $10.5-11.1$ & 31.06 & 22.98 \\
\hline \multirow[t]{6}{*}{ MW-8B } & $1.5-3.5$ & 23.50 & 17.88 \\
\hline & $3.5-5.5$ & 20.88 & 15.84 \\
\hline & $5.5-7.5$ & 20.54 & 15.04 \\
\hline & $7.5-8.8$ & 20.86 & 13.94 \\
\hline & $8.8-10.8$ & 22.04 & 15.97 \\
\hline & $10.8-12.0$ & 31.33 & 22.95 \\
\hline \multirow[t]{4}{*}{ MW-9B } & $0-1.5$ & 40.86 & 32.17 \\
\hline & $1.5-4.5$ & 51.13 & 46.05 \\
\hline & $4.5-8.8$ & 28.13 & 21.95 \\
\hline & $8.8-10.7$ & 25.89 & 20.00 \\
\hline \multirow[t]{5}{*}{ MW-10B } & $1.5-3.5$ & 28.93 & 20.16 \\
\hline & $3.5-5.5$ & 21.64 & 17.92 \\
\hline & $5.5-7.5$ & 18.62 & 15.96 \\
\hline & $7.5-9.5$ & 19.02 & 13.84 \\
\hline & $9.5-11.2$ & 33.18 & 22.49 \\
\hline \multirow[t]{4}{*}{ MW-12B } & $0-1.5$ & 33.64 & 25.30 \\
\hline & $1.5-3.8$ & 31.95 & 23.58 \\
\hline & $3.8-9.8$ & 22.55 & 17.62 \\
\hline & $9.8-10.5$ & 32.39 & 22.25 \\
\hline \multirow[t]{7}{*}{ MW-13B } & $1.5-3.5$ & 24.35 & 19.61 \\
\hline & $3.5-5.5$ & 22.09 & 18.38 \\
\hline & $5.5-7.5$ & 21.11 & 17.20 \\
\hline & $7.5-9.5$ & 20.11 & 15.82 \\
\hline & $9.5-11.5$ & 19.24 & 14.18 \\
\hline & $11.5-13.5$ & 21.86 & 15.96 \\
\hline & $13.5-14.3$ & 30.75 & 22.39 \\
\hline \multirow[t]{5}{*}{ MW-14B } & $0-1.5$ & 28.23 & 20.81 \\
\hline & $1.5-2.9$ & 30.12 & 21.73 \\
\hline & $2.9-5.5$ & 19.37 & 16.62 \\
\hline & $5.5-10.1$ & 25.01 & 16.30 \\
\hline & $10.1-13.5$ & 19.51 & 17.45 \\
\hline
\end{tabular}




\begin{tabular}{|c|c|c|c|}
\hline MW-15B & $1.5-3.5$ & 28.30 & 19.47 \\
\hline & $3.5-5.5$ & 22.28 & 18.41 \\
\hline & $5.5-7.5$ & 19.97 & 16.90 \\
\hline & $7.5-9.5$ & 19.87 & 15.11 \\
\hline & $9.5-11.5$ & 24.77 & 18.46 \\
\hline & $11.5-12.1$ & 29.77 & 24.38 \\
\hline R-2B & $1.5-3.5$ & 31.21 & 20.41 \\
\hline & $3.5-5.5$ & 30.01 & 22.19 \\
\hline & $5.5-6.2$ & 27.76 & 18.88 \\
\hline R-3B & $0-1.5$ & 27.76 & 19.30 \\
\hline & $1.5-4.0$ & 31.36 & 21.99 \\
\hline & $4.0-7.0$ & 20.58 & 15.08 \\
\hline & $7.0-10.5$ & 22.12 & 16.35 \\
\hline
\end{tabular}

\subsection{Specific Gravity}

Specific gravity tests were performed for each well site. Tests were performed on the top layer of soil and the bottom most soil layer at each well location. Specific gravity tests were performed to aid in the process of reconstructing samples. Results from the specific gravity tests are shown below.

Table 4-4: Specific Gravity for Montrose Site.

\begin{tabular}{|c|c|c|}
\hline $\begin{array}{c}\text { Well } \\
\text { Location }\end{array}$ & Depth (ft.) & $\begin{array}{c}\text { Specific } \\
\text { Gravity }\end{array}$ \\
\hline MW-2B & $0-1.5$ & 2.70 \\
\hline & $6.2-9.0$ & 2.85 \\
\hline MW-3B & $1.5-3.5$ & 2.52 \\
\hline & $7.5-9.0$ & 2.86 \\
\hline MW-4B & $1.5-3.5$ & 2.73 \\
\hline & $11.5-13.1$ & 2.85 \\
\hline MW-5B & $0-1.5$ & 2.75 \\
\hline & $5.5-8.0$ & 2.79 \\
\hline MW-6B & $1.5-3.5$ & 2.67 \\
\hline & $10.5-12.0$ & 2.79 \\
\hline MW-7B & $1.5-3.5$ & 2.68 \\
\hline & $10.5-11.1$ & 2.77 \\
\hline MW-8B & $1.5-3.5$ & 2.76 \\
\hline & $10.8-12.0$ & 2.82 \\
\hline MW-9B & $0-1.5$ & 2.78 \\
\hline & $8.8-10.7$ & 2.79 \\
\hline & &
\end{tabular}

\begin{tabular}{|c|c|c|}
\hline $\begin{array}{c}\text { Well } \\
\text { Location }\end{array}$ & Depth (ft.) & $\begin{array}{c}\text { Specific } \\
\text { Gravity }\end{array}$ \\
\hline MW-10B & $1.5-3.5$ & 2.69 \\
\hline & $9.5-11.2$ & 2.83 \\
\hline MW-12B & $0-1.5$ & 2.73 \\
\hline & $9.8-10.5$ & 2.82 \\
\hline MW-13B & $1.5-3.5$ & 2.63 \\
\hline & $13.5-14.3$ & 2.86 \\
\hline MW-14B & $0-1.5$ & 2.71 \\
\hline & $10.1-13.5$ & 2.80 \\
\hline MW-15B & $1.5-3.5$ & 2.73 \\
\hline & $11.5-12.1$ & 2.69 \\
\hline R-2B & $1.5-3.5$ & 2.85 \\
\hline & $5.5-6.2$ & 2.79 \\
\hline R-3B & $0-1.5$ & 2.70 \\
\hline & $7.0-10.5$ & 2.81 \\
\hline
\end{tabular}




\subsection{Hydraulic Conductivity}

Hydraulic conductivity tests were performed on Shelby tube samples from MW-

7B and MW-8B, tests were also performed on reconstructed samples from MW-2B and MW-3B. The depth for the shelby tube sample at MW-7B is 9.5' to 10.5' and the depth for MW-8B is $7.5^{\prime}$ to $8.8^{\prime}$. The depth for the reconstructed sample at MW-2B is $1.5^{\prime}$ to 4.8'. The reconstructed sample at MW-3B was taken from material from the ground surface. Various tests were performed on the reconstructed samples to gather a consistent set of results. Variations in results occurred due to the variability of reconstructing samples. Results from tests were determined to be within a suitable range of error. Testing was performed to determine the permeability of the soil at the site. The results from hydraulic conductivity tests are shown below.

Table 4-5: Hydraulic Conductivity Values.

\begin{tabular}{|c|c|c|}
\hline Well Location & $\begin{array}{c}\text { Depth } \\
\text { (ft) }\end{array}$ & $\begin{array}{c}\text { Hydraulic Conductivity } \\
\text { (cm/s) }\end{array}$ \\
\hline MW-7B & $9.5^{\prime}-10.5^{\prime}$ & $5.09 \times 10^{-7}$ \\
\hline MW-8B & $7.5^{\prime}-8.8^{\prime}$ & $3.20 \times 10^{-7}$ \\
\hline MW-2B (First Set) & $1.5^{\prime}-4.8^{\prime}$ & $3.71 \times 10^{-8}$ \\
\hline MW-3B (First Set) & $0-1.0^{\prime}$ & $5.89 \times 10^{-7}$ \\
\hline MW-2B (Second Set) & $1.5^{\prime}-4.8^{\prime}$ & $4.11 \times 10^{-8}$ \\
\hline MW-3B (Second Set) & $0-1.0^{\prime}$ & $9.08 \times 10^{-7}$ \\
\hline MW-2B (Third Set) & $1.5^{\prime}-4.8^{\prime}$ & $4.75 \times 10^{-8}$ \\
\hline MW-3B (Third Set) & $0-1.0^{\prime}$ & $3.07 \times 10^{-7}$ \\
\hline \multicolumn{2}{|c|}{ Average Hydraulic Conductivity $=$} & $3.45 \times 10^{-7}$ \\
\hline
\end{tabular}




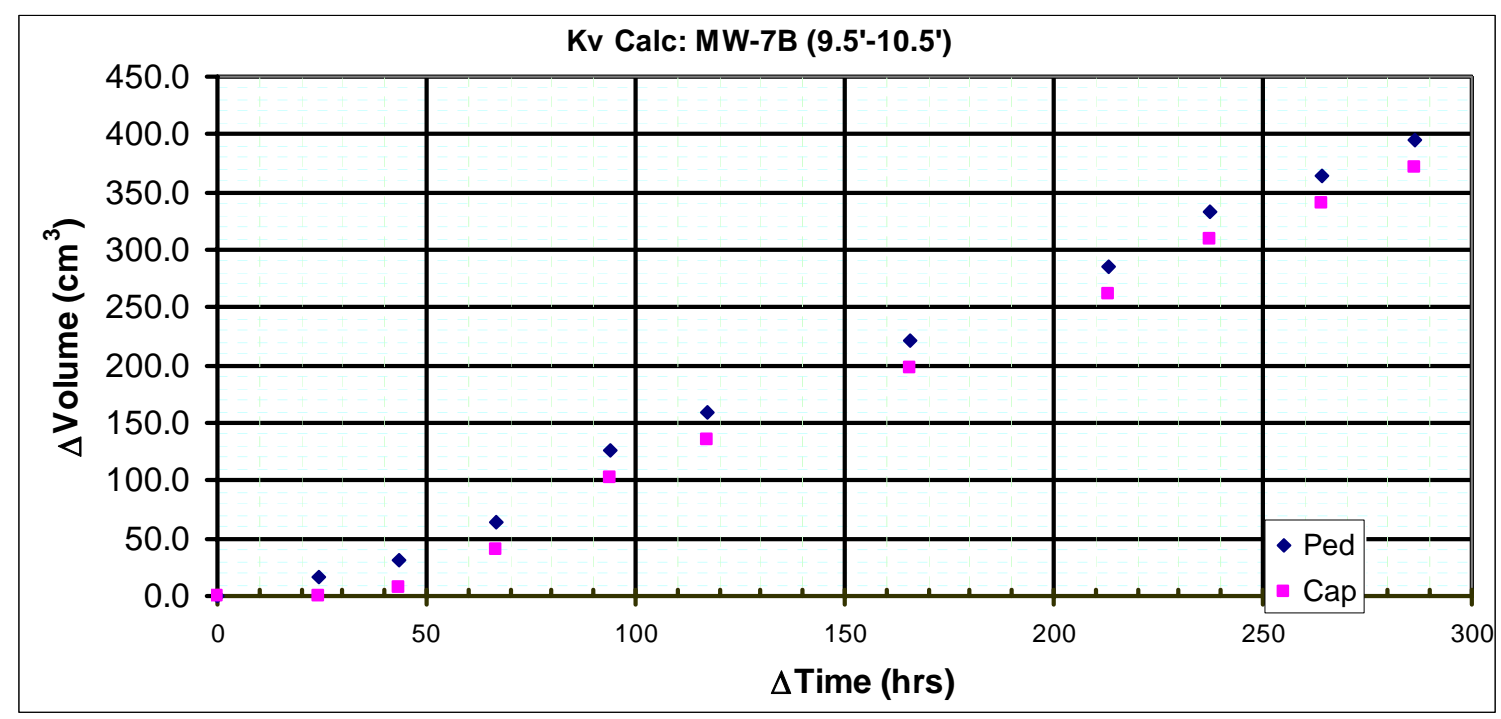

Figure 4-1: Graph of Variation of Flow Volume with Time for MW-7B.

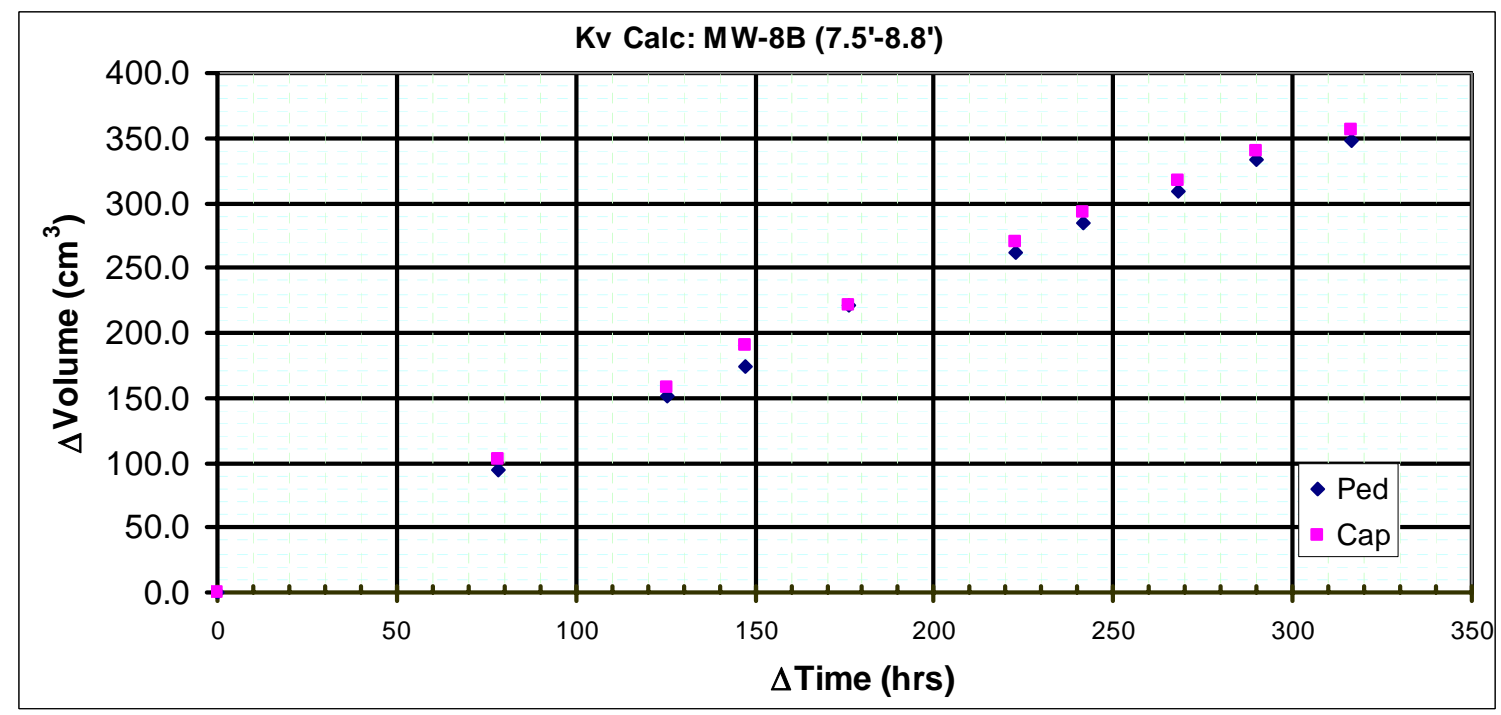

Figure 4-2: Graph of Variation of Flow Volume with Time for MW-8B. 


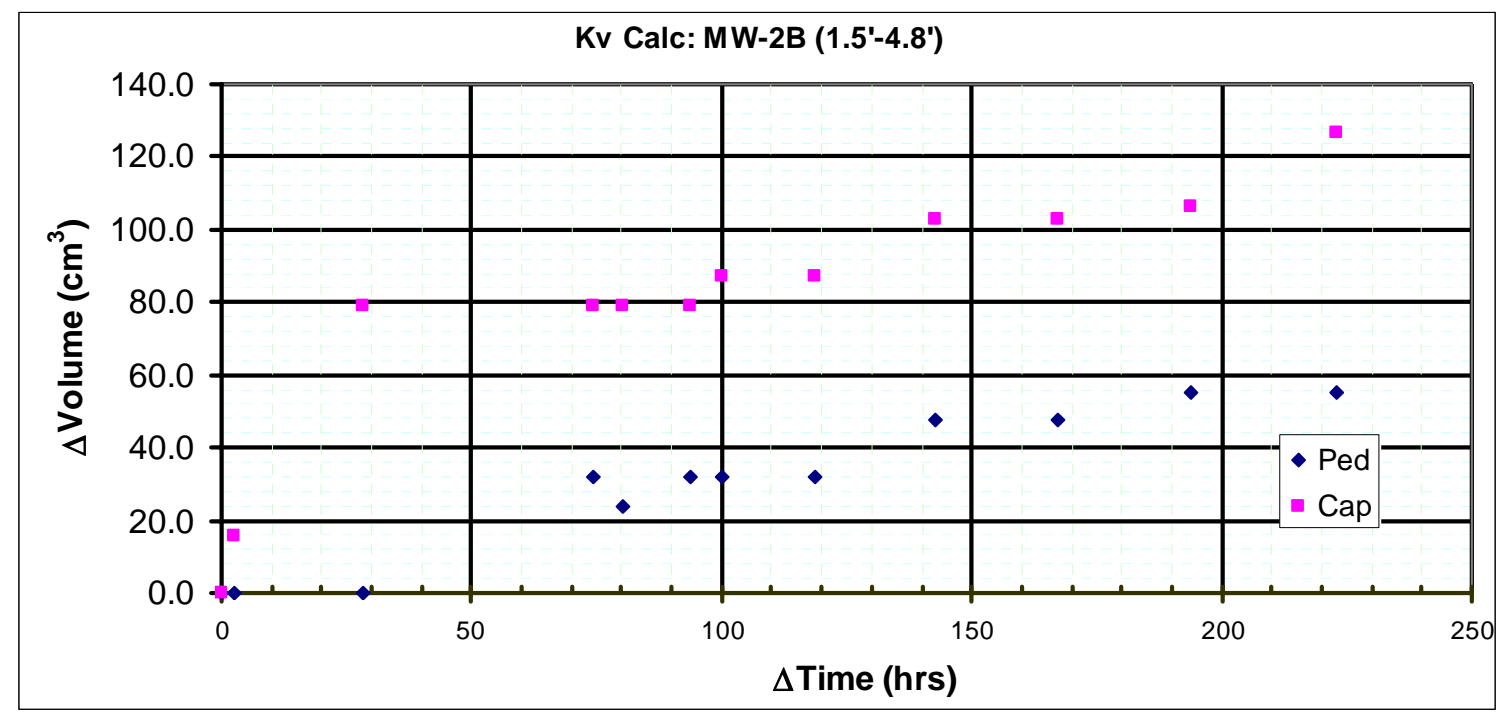

Figure 4-3: Graph of Variation of Flow Volume with Time for MW-2B, Set One.

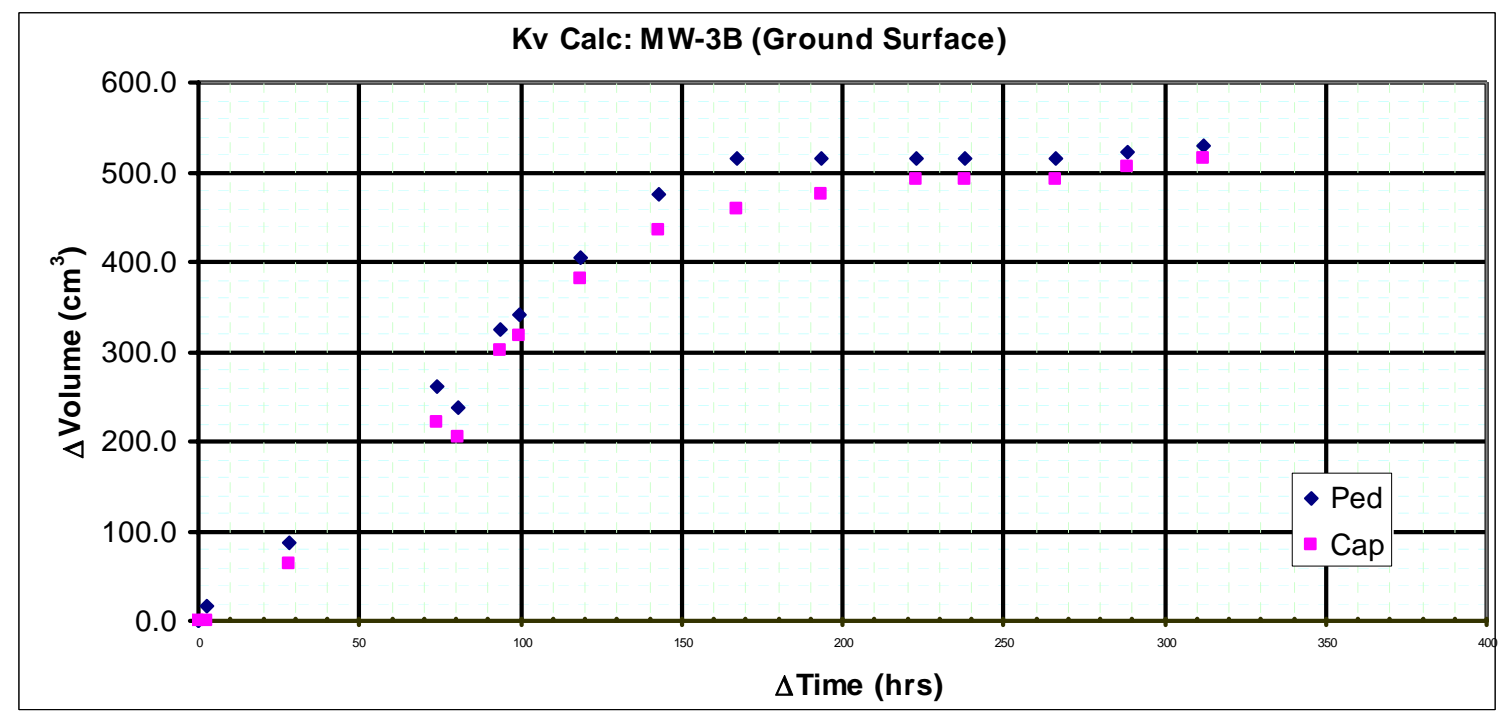

Figure 4-4: Graph of Variation of Flow Volume with Time for MW-3B, Set One. 


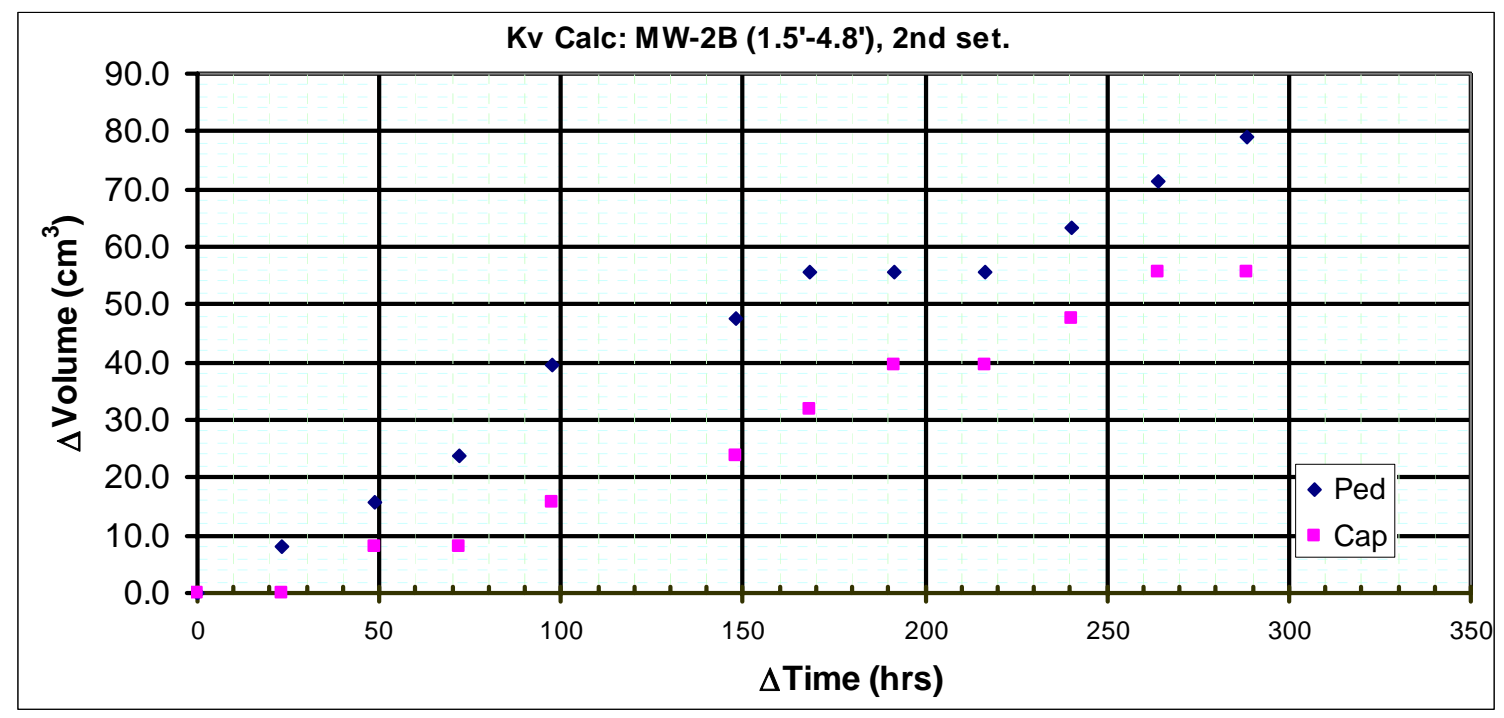

Figure 4-5: Graph of Variation of Flow Volume with Time for MW-2B, Set Two.

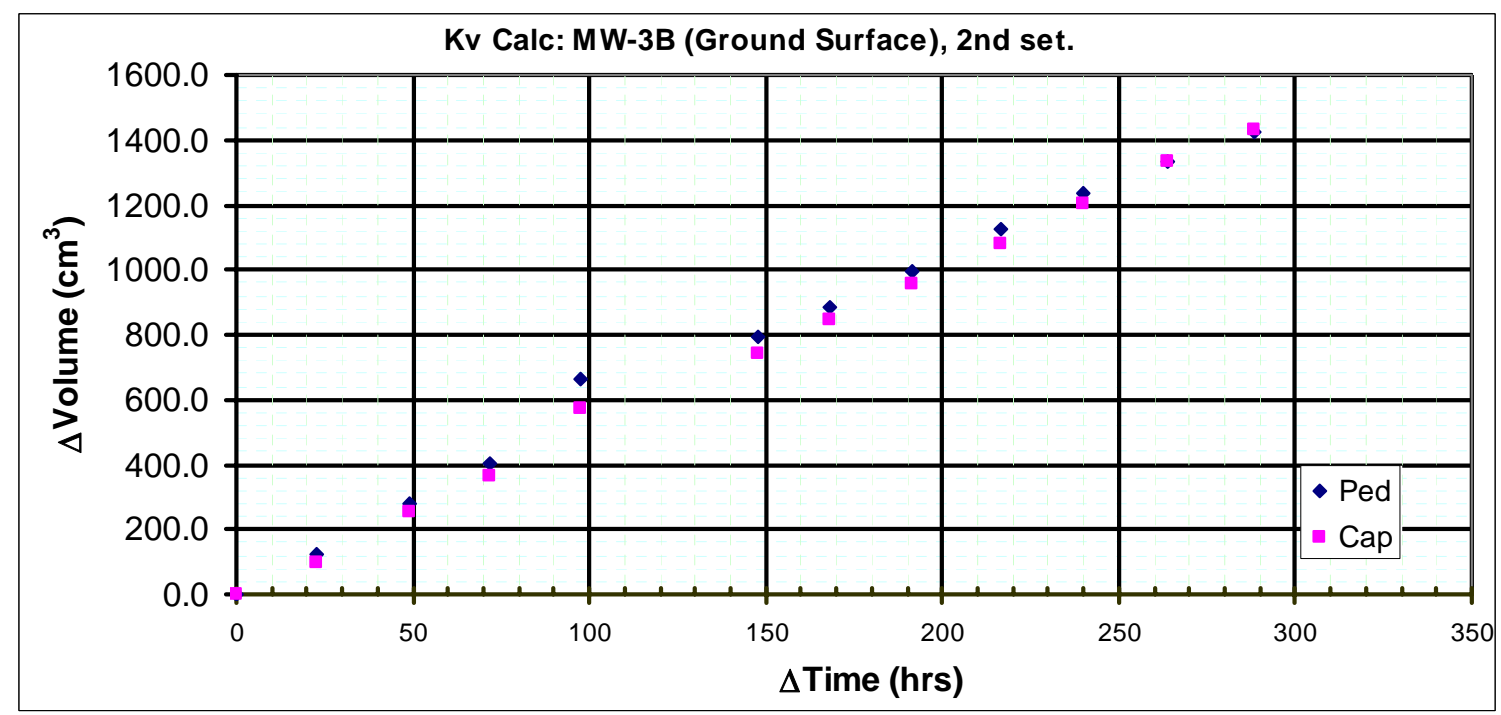

Figure 4-6: Graph of Variation of Flow Volume with Time for MW-3B, Set Two. 


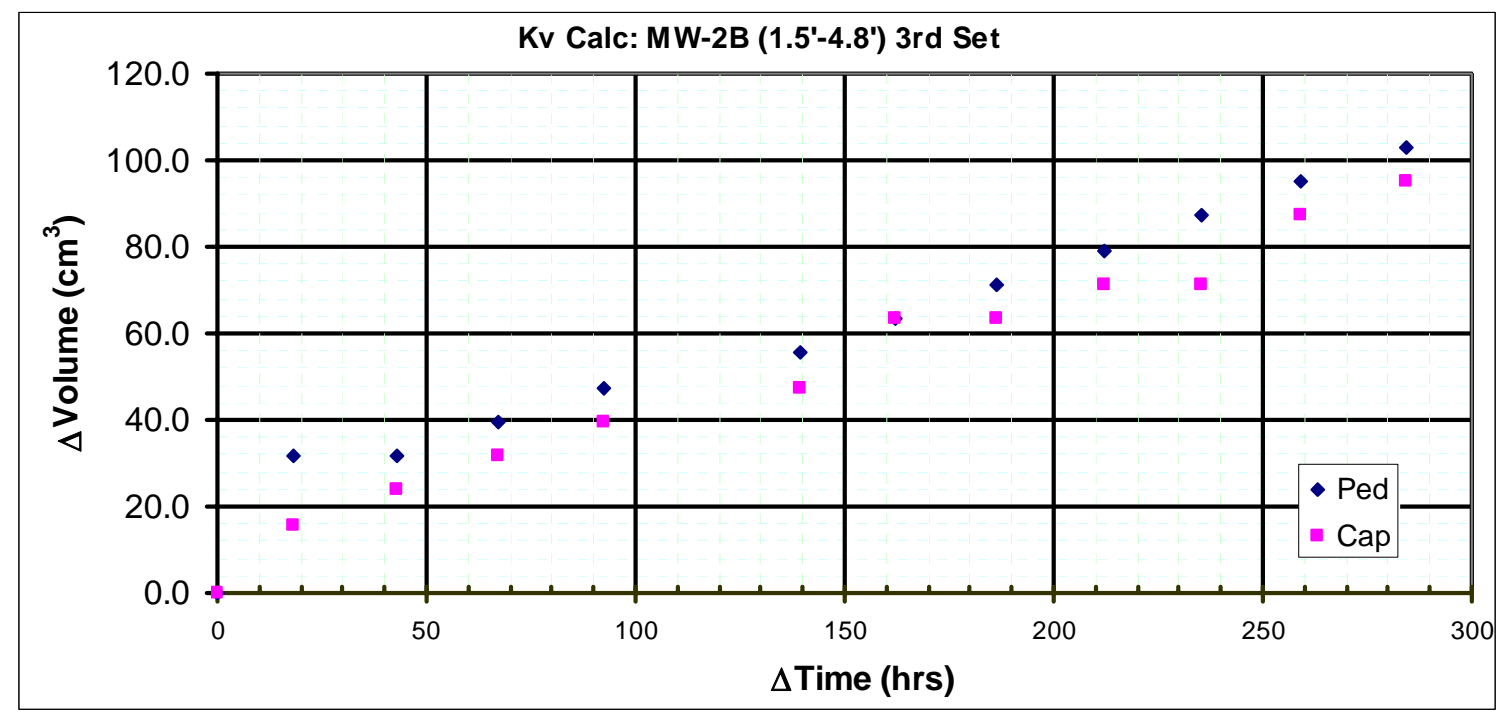

Figure 4-7: Graph of Variation of Flow Volume with Time for MW-2B, Set Three.

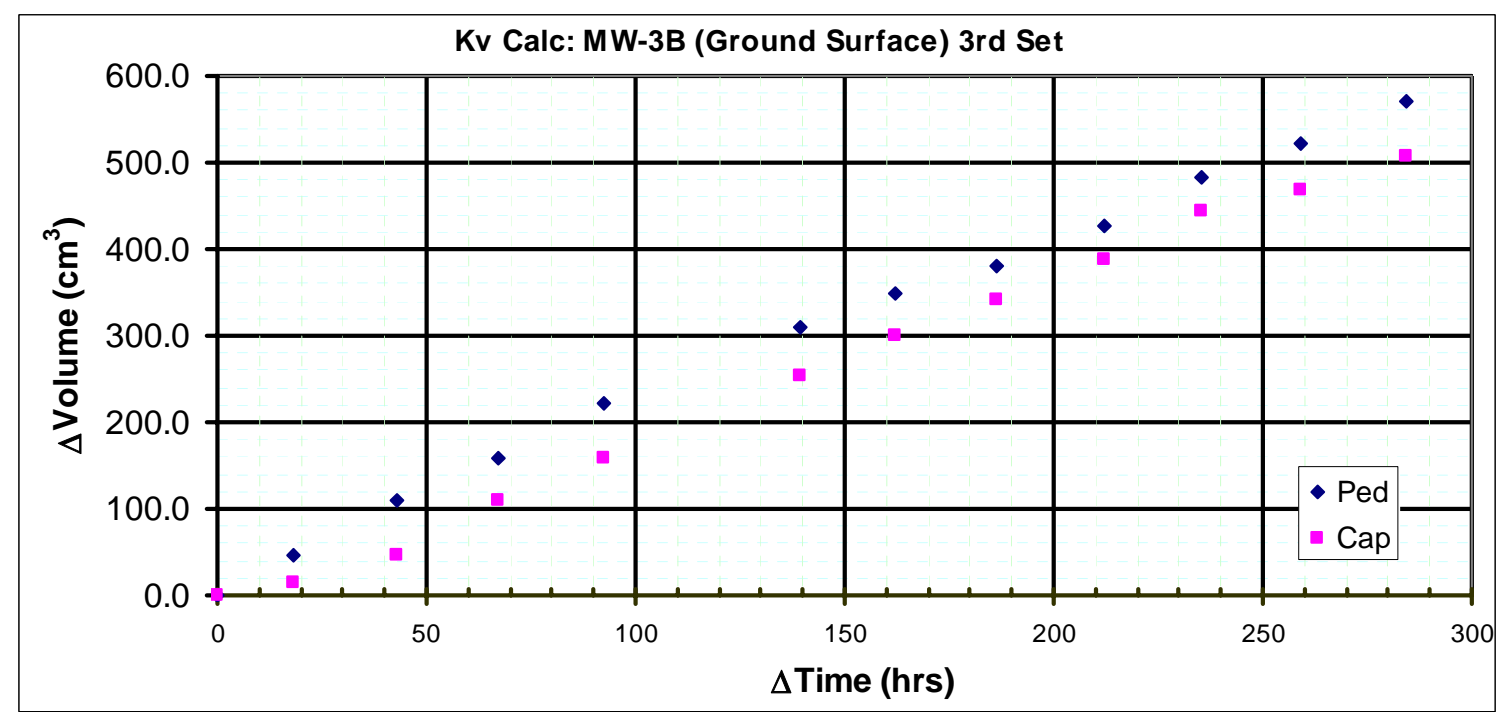

Figure 4-8: Graph of Variation of Flow Volume with Time for MW-3B, Set Three. 


\subsection{Field Density}

The determination of the field density at the site was needed for the reconstruction of soil samples. This process had many different steps and procedures. The first was to determine the density of Ottawa sand using the sand cone method. Next the density of a spilt spoon sample from MW-3B was determined. A sand cone test was performed at the site to determine the density of the ground surface. Results from these tests were used in the reconstruction of soil samples. Tests were performed until a consistent set of results was obtained. The average density used for reconstruction analysis was $92 \mathrm{lb} / \mathrm{ft}^{3}$. Typical results are shown below.

Table 4-6: Table of density values.

\begin{tabular}{|c|c|c|}
\hline Test & Density & Value \\
\hline $\begin{array}{c}\text { Lab Test on Ottawa Sand } \\
\text { (Sand Cone Method) }\end{array}$ & $\gamma$ & $96.14 \mathrm{lb} / \mathrm{ft}^{3}$ \\
\hline $\begin{array}{c}\text { Lab Test on Split Spoon } \\
\text { Sample From MW-3B } \\
\text { (Sand Cone Method) }\end{array}$ & $\gamma_{\text {wet }}$ & $100.4 \mathrm{lb} / \mathrm{ft}^{3}$ \\
\cline { 2 - 3 } $\begin{array}{c}\text { Field Test at MW-3B } \\
\text { (Sand Cone Method) }\end{array}$ & $\gamma_{\text {dry }}$ & $94.2 \mathrm{lb} / \mathrm{ft}^{3}$ \\
\cline { 2 - 3 } & $\gamma_{\text {wet }}$ & $131.8 \mathrm{lb} / \mathrm{ft}^{3}$ \\
\hline
\end{tabular}

\subsection{Grain Size}

The determination of the grain size particles of each soil sample at the site was needed in the classification process. The two types of tests used to determine the particle sizes were sieve analysis and the hydrometer analysis. Typical results from the sieve analysis are shown below and results from hydrometer tests can be found in the appendix B. 


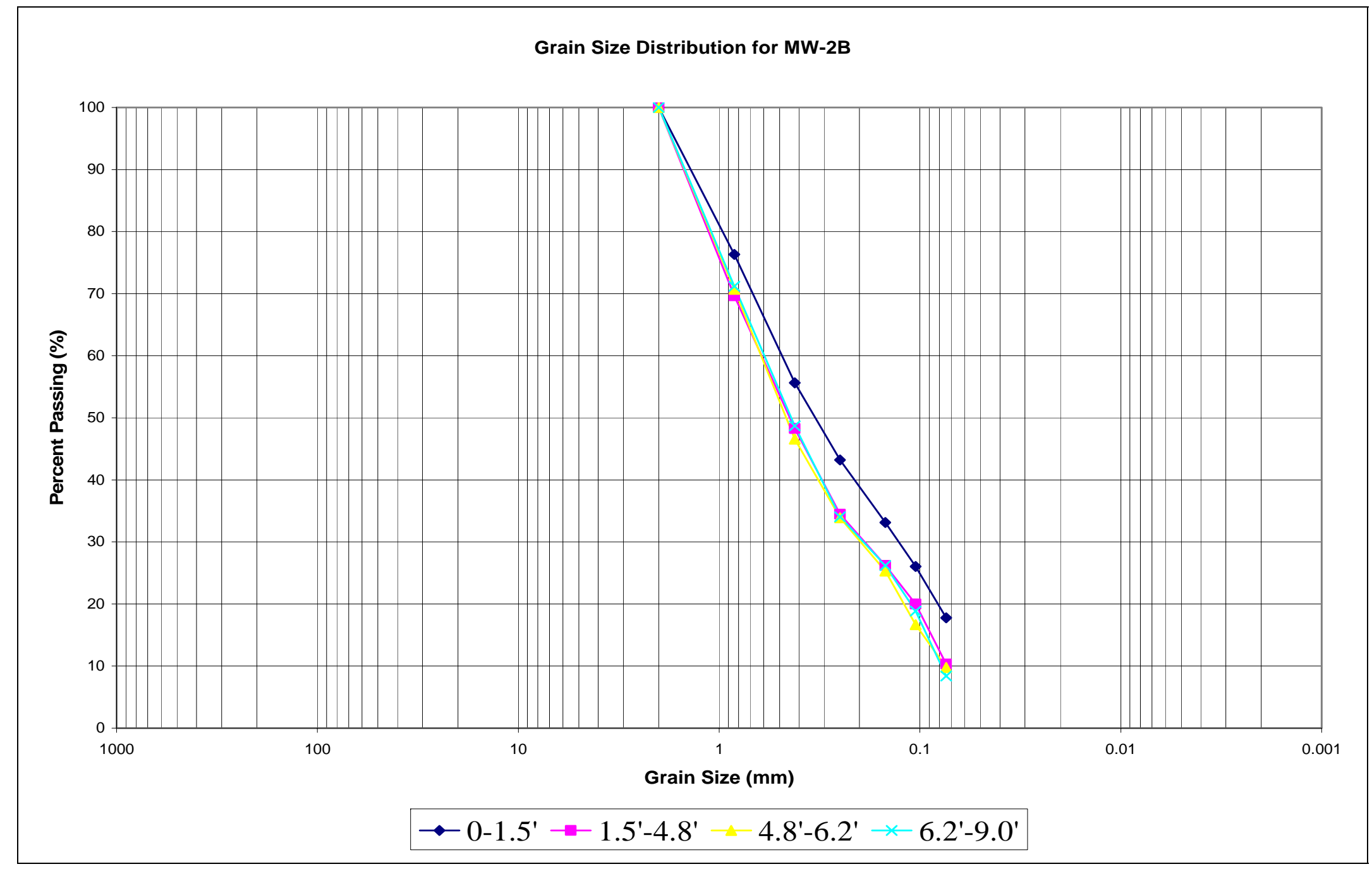

Figure 4-9: Grain Size Distribution Curve for MW-2B. 


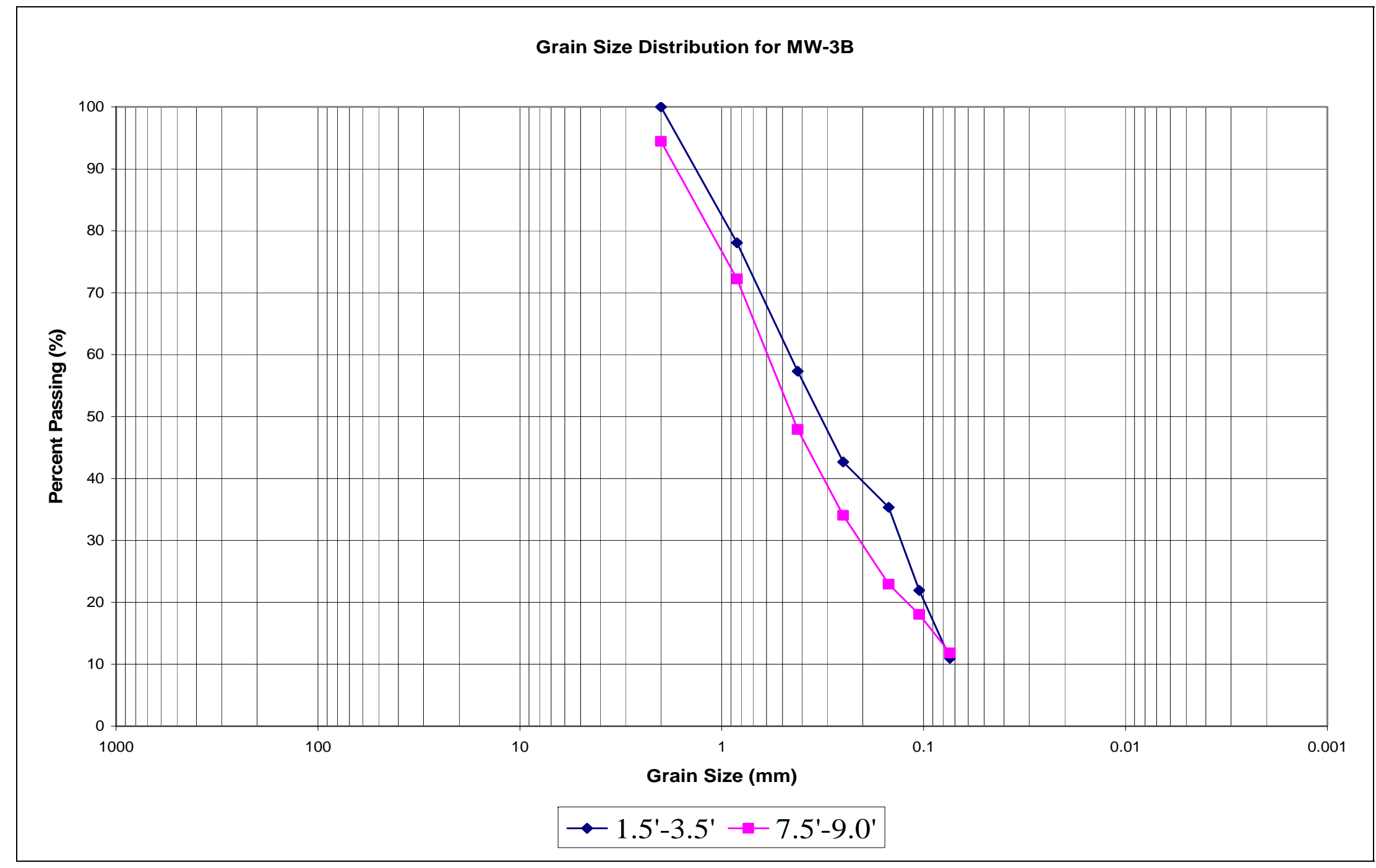

Figure 4-10: Grain Size Distribution Curve for MW-3B. 


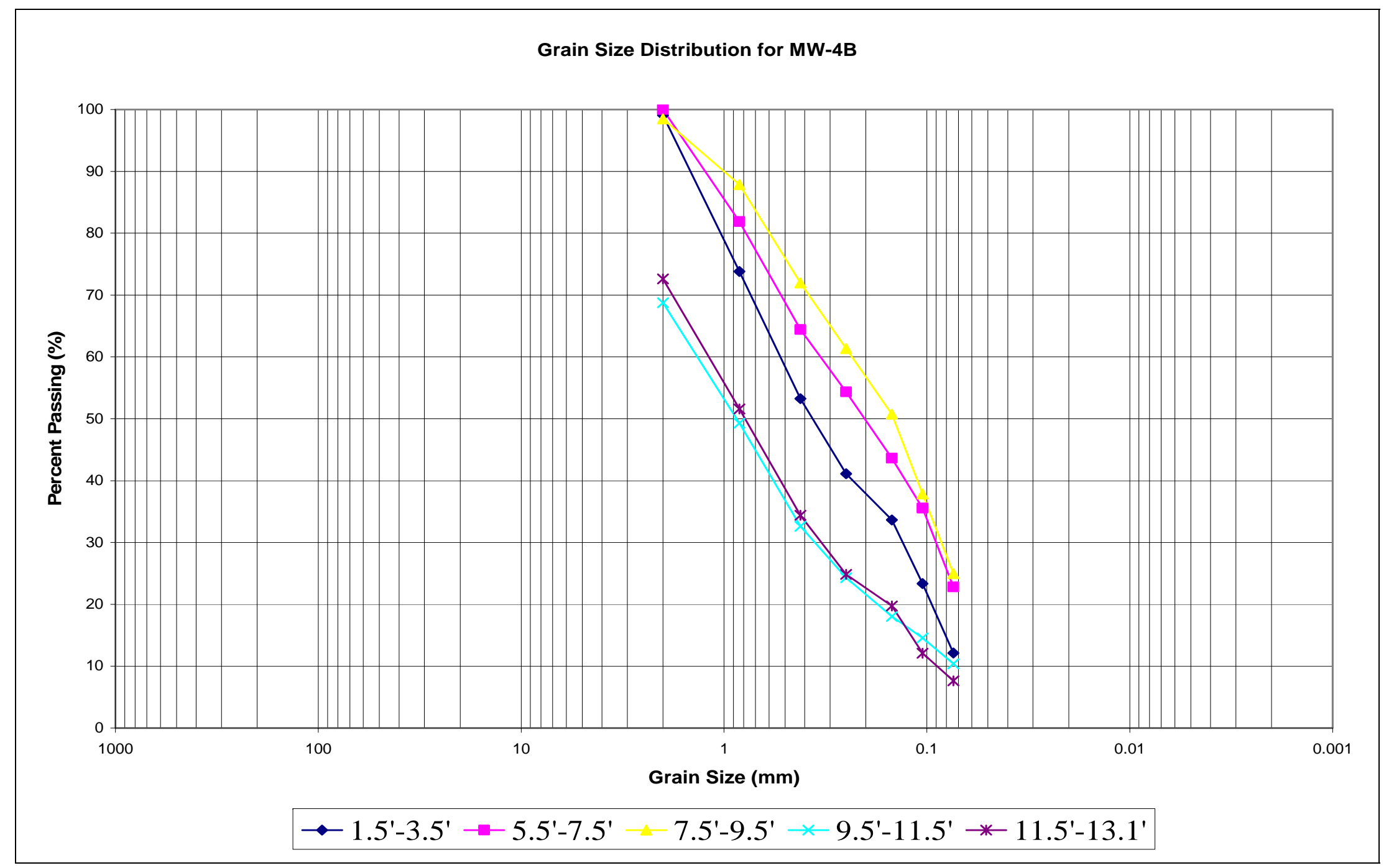

Figure 4-11: Grain Size Distribution Curve for MW-4B. 


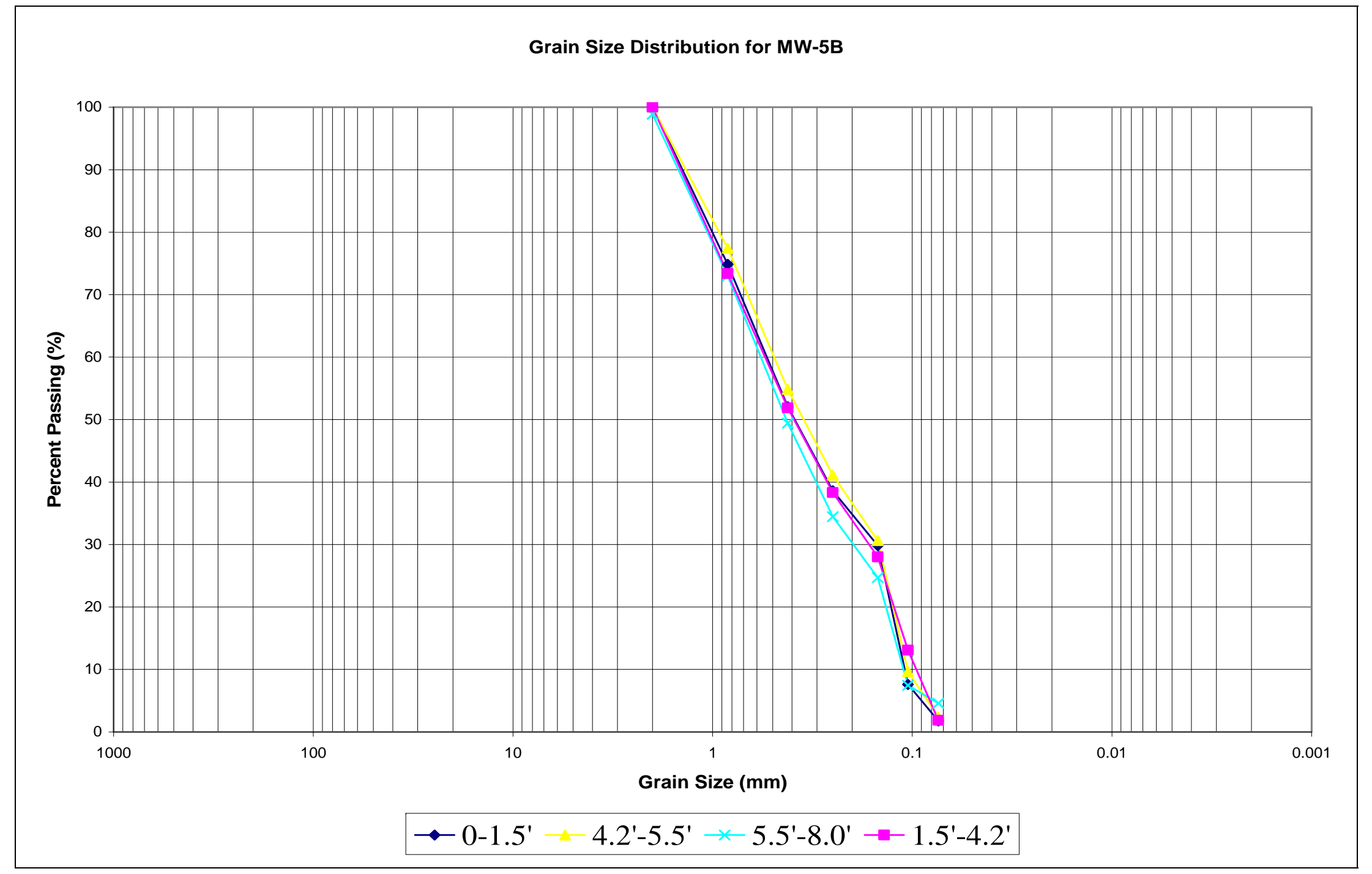

Figure 4-12: Grain Size Distribution Curve for MW-5B. 


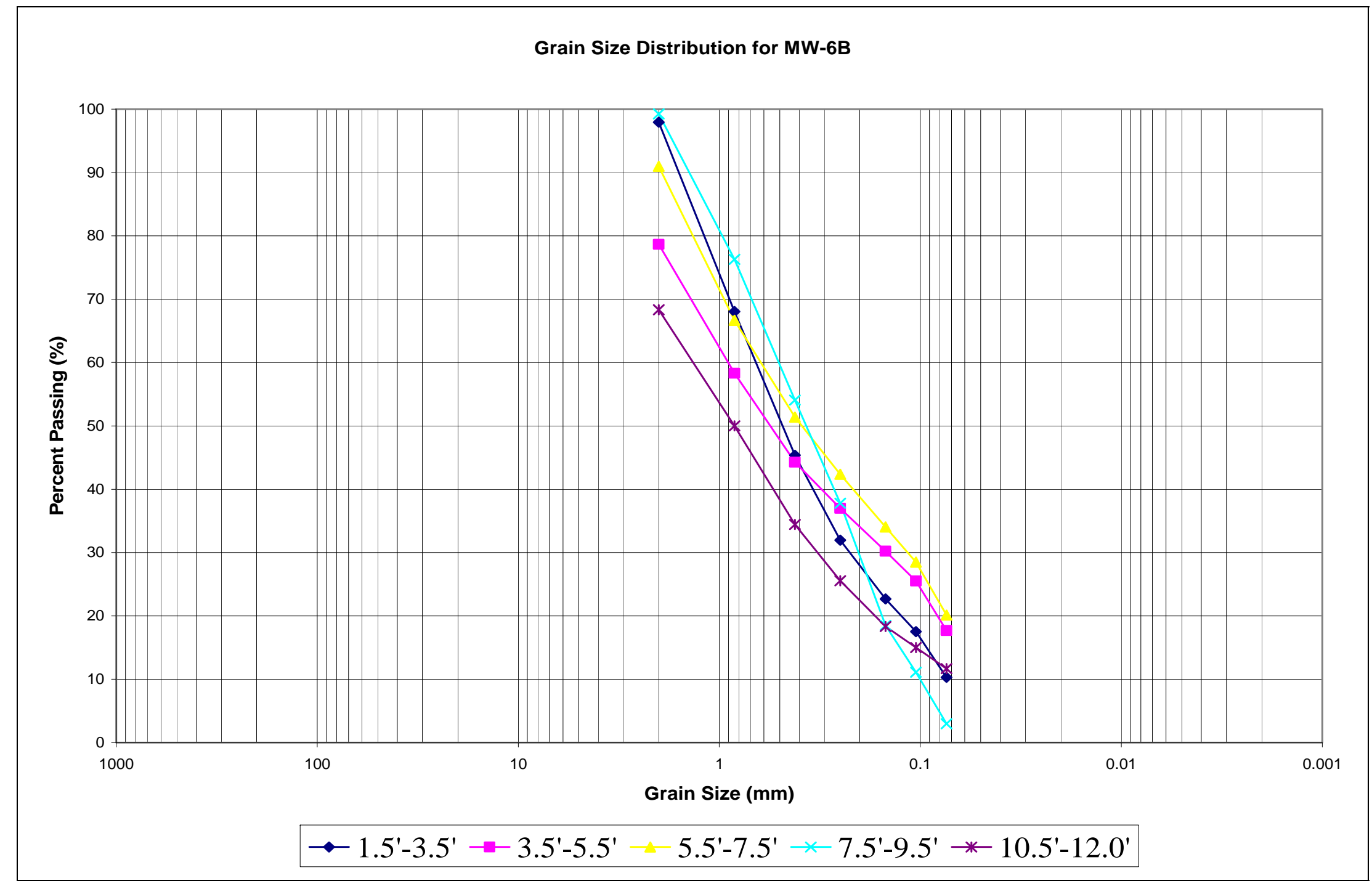

Figure 4-13: Grain Size Distribution Curve for MW-6B. 


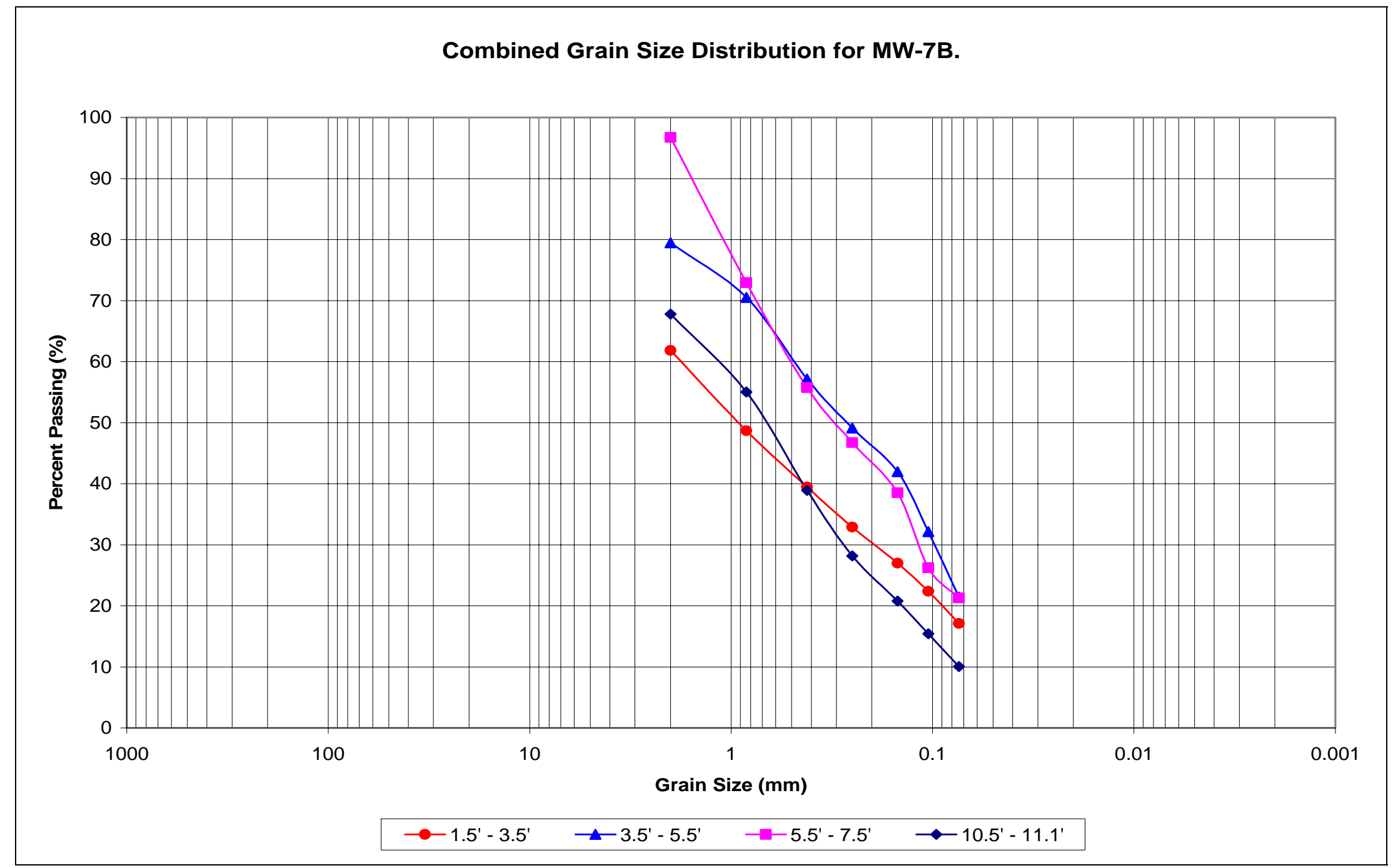

Figure 4-14: Grain Size Distribution Curve for MW-7B. 


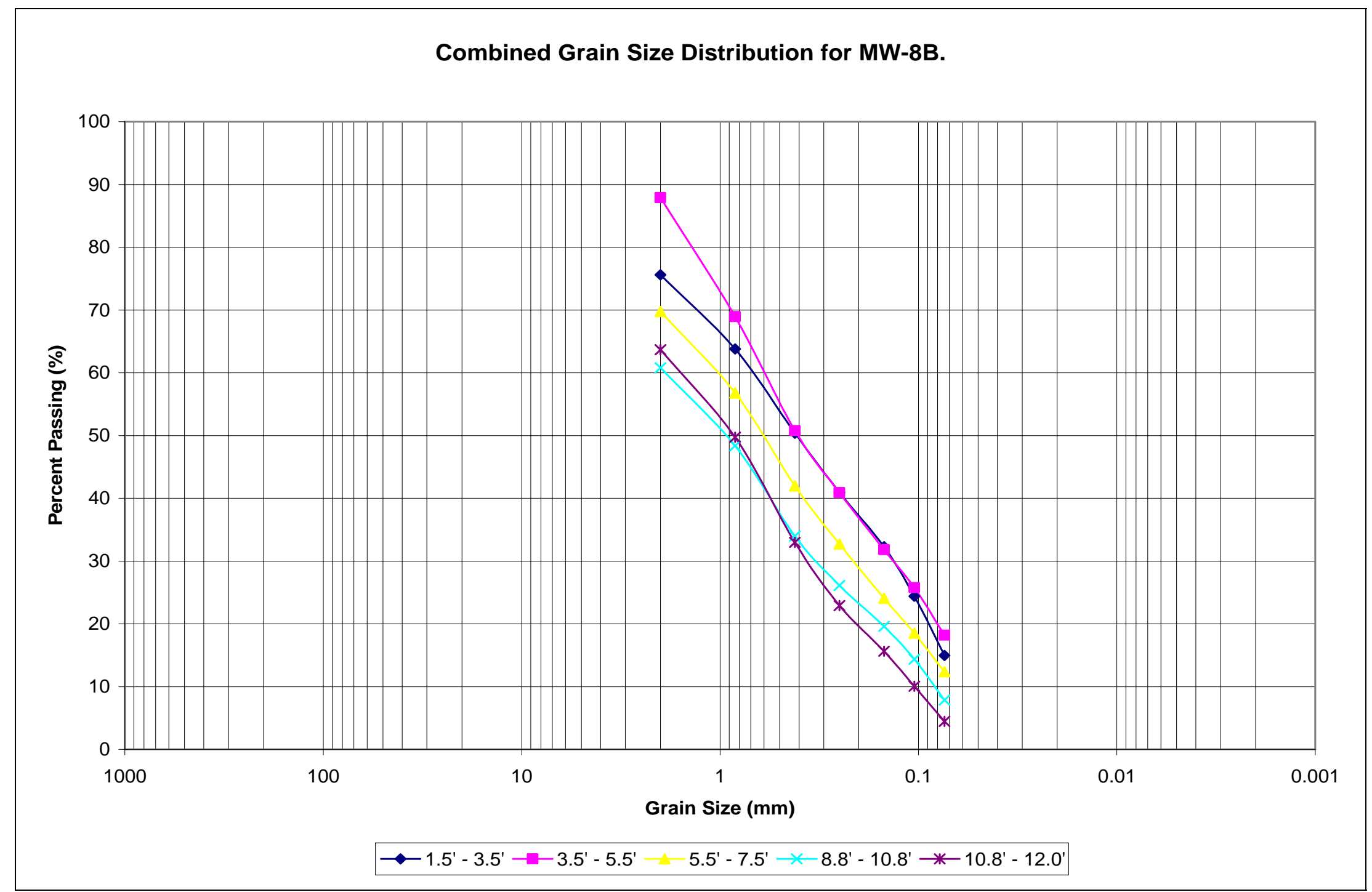

Figure 4-15: Grain Size Distribution Curve for MW-8B. 




Figure 4-16: Grain Size Distribution Curve for MW-9B. 


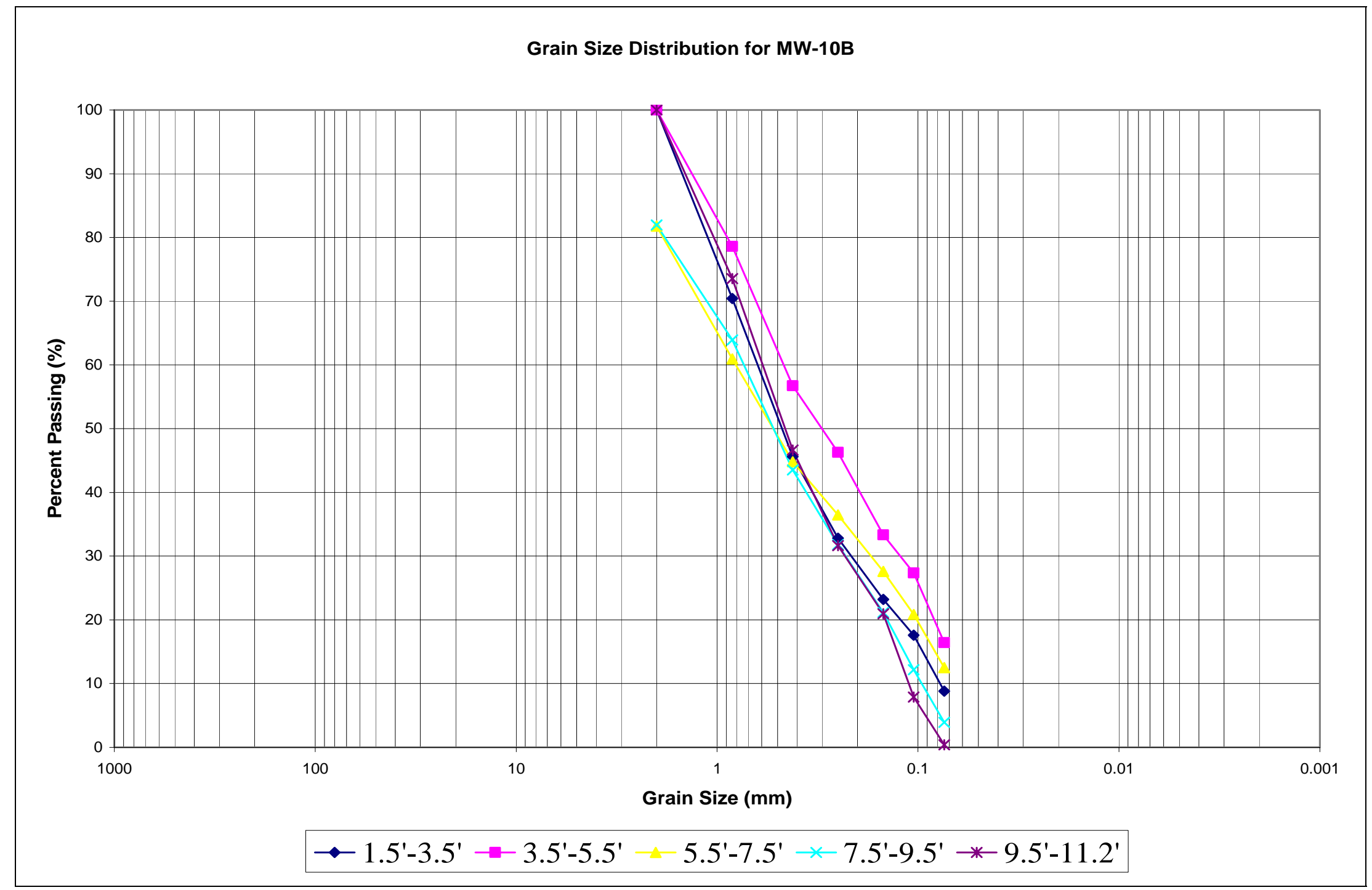

Figure 4-17: Grain Size Distribution Curve for MW-10B. 


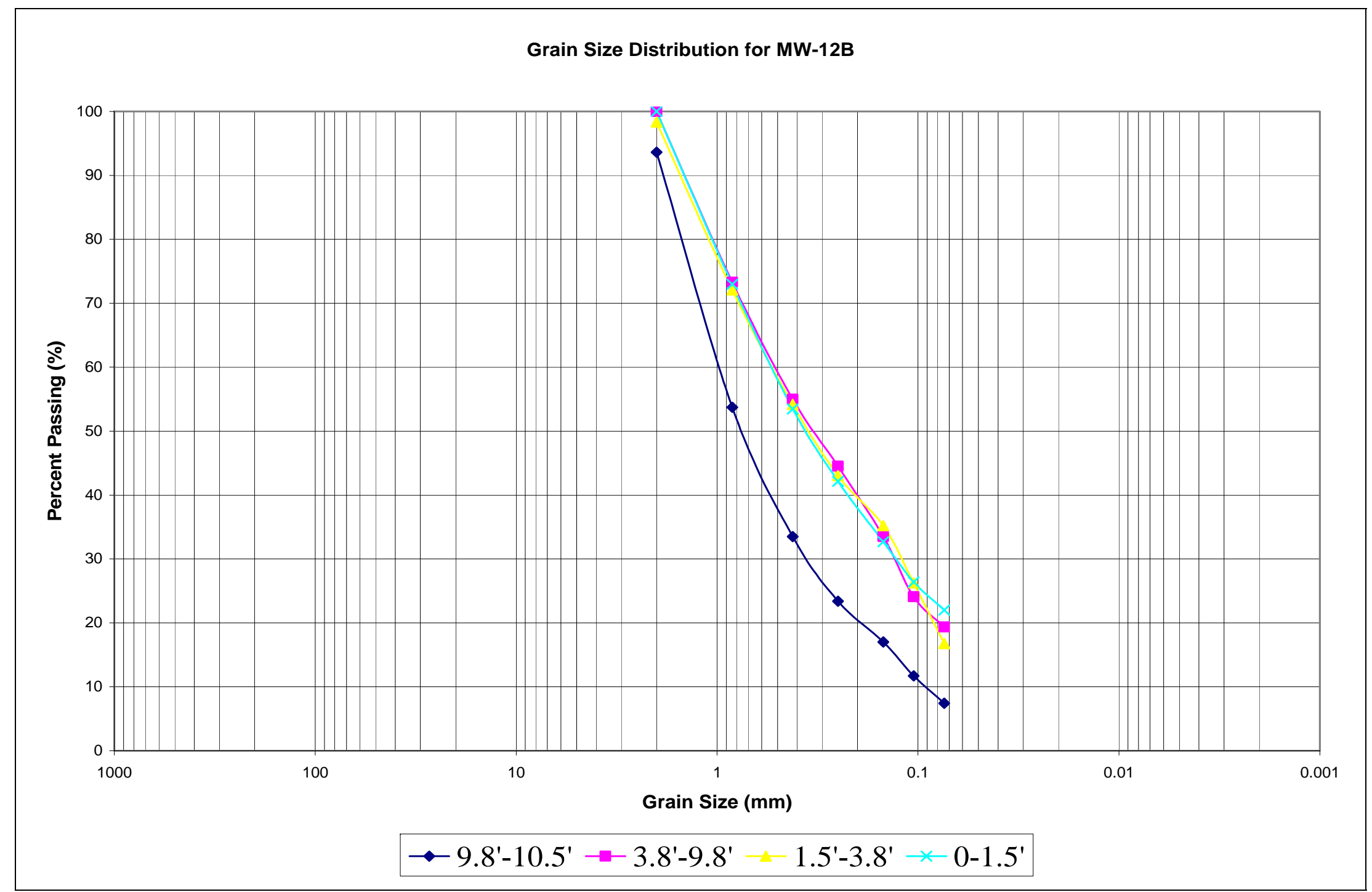

Figure 4-18: Grain Size Distribution Curve for MW-12B. 


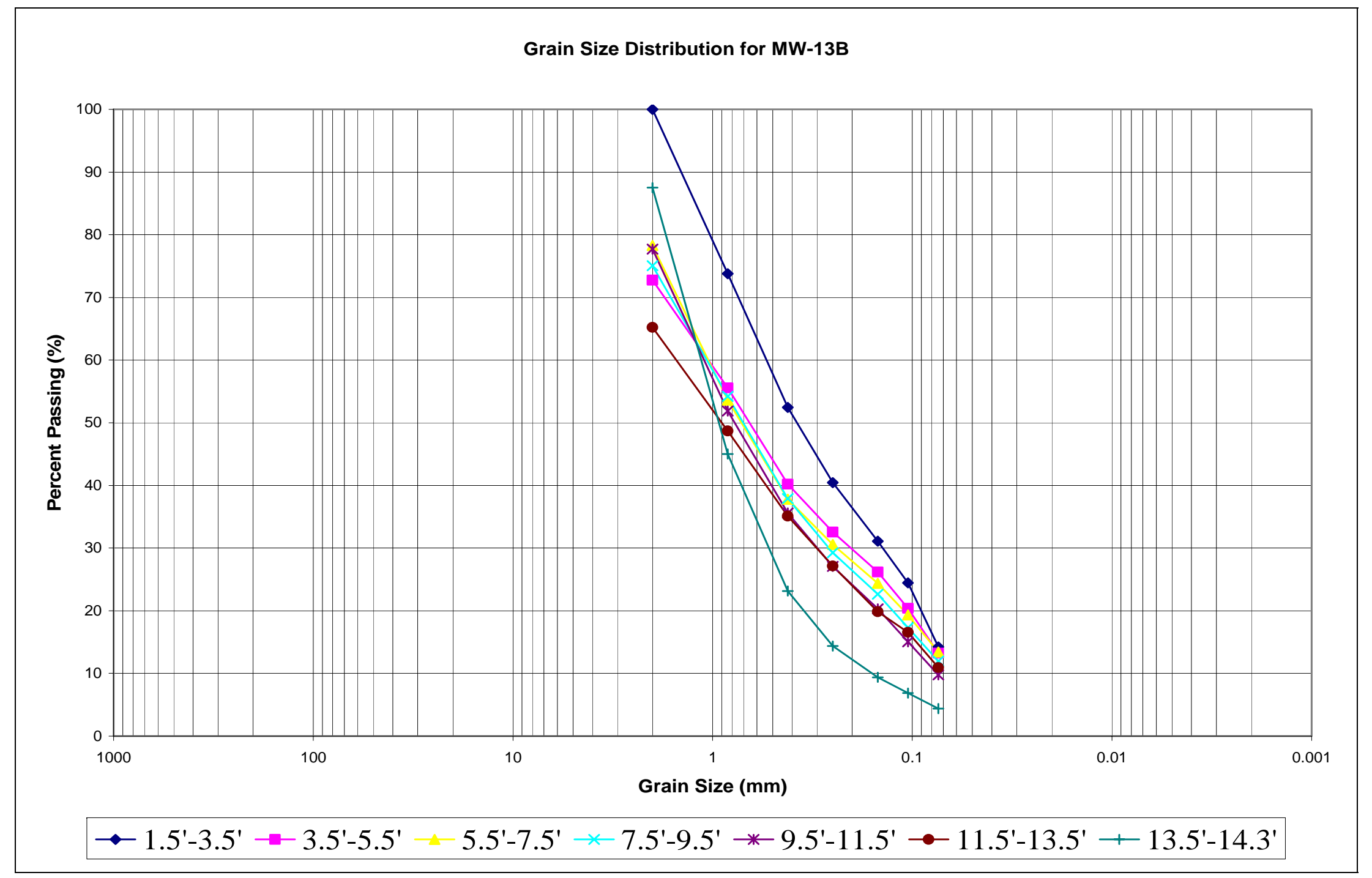

Figure 4-19: Grain Size Distribution Curve for MW-13B. 


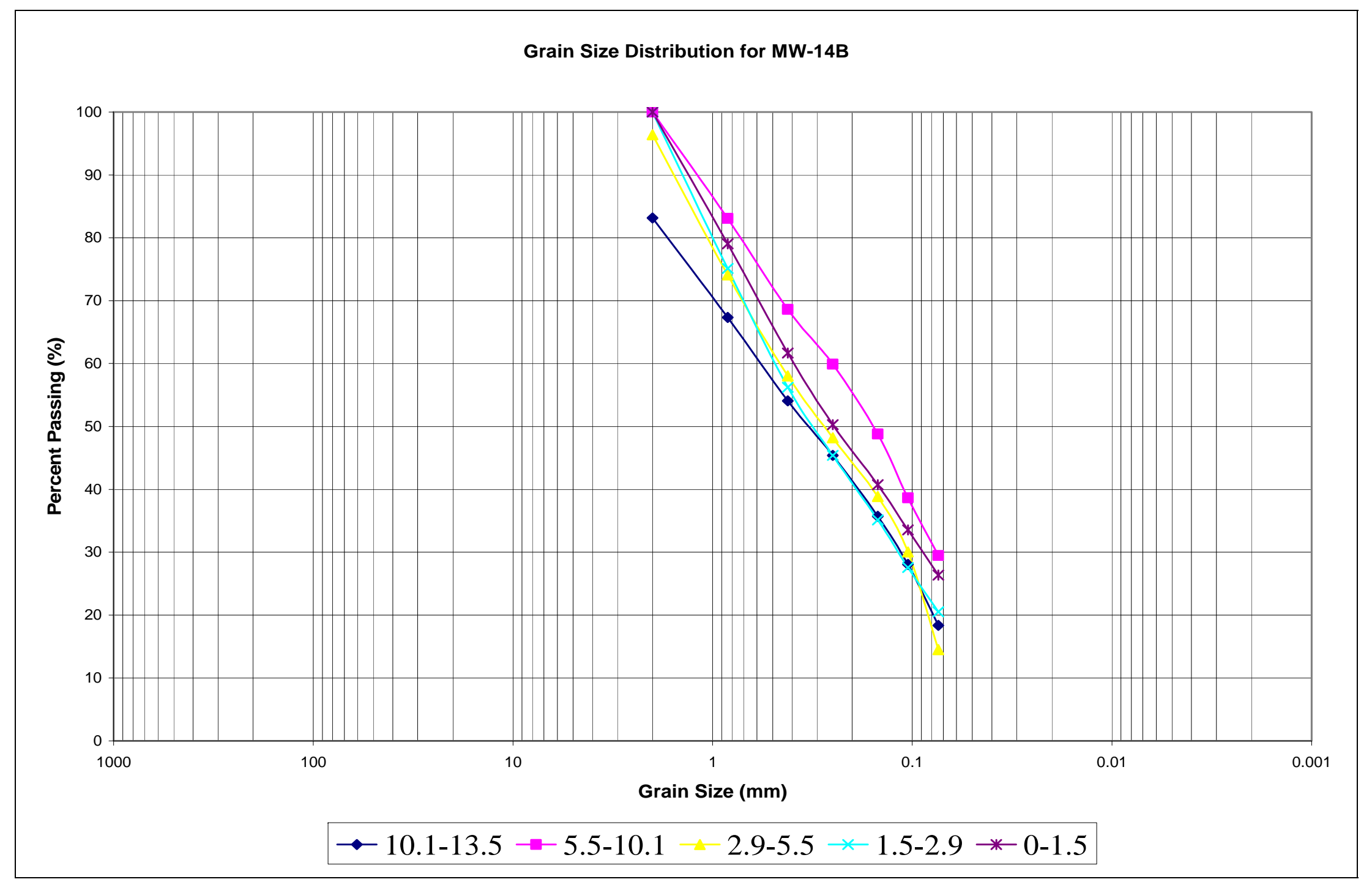

Figure 4-20: Grain Size Distribution Curve for MW-14B. 


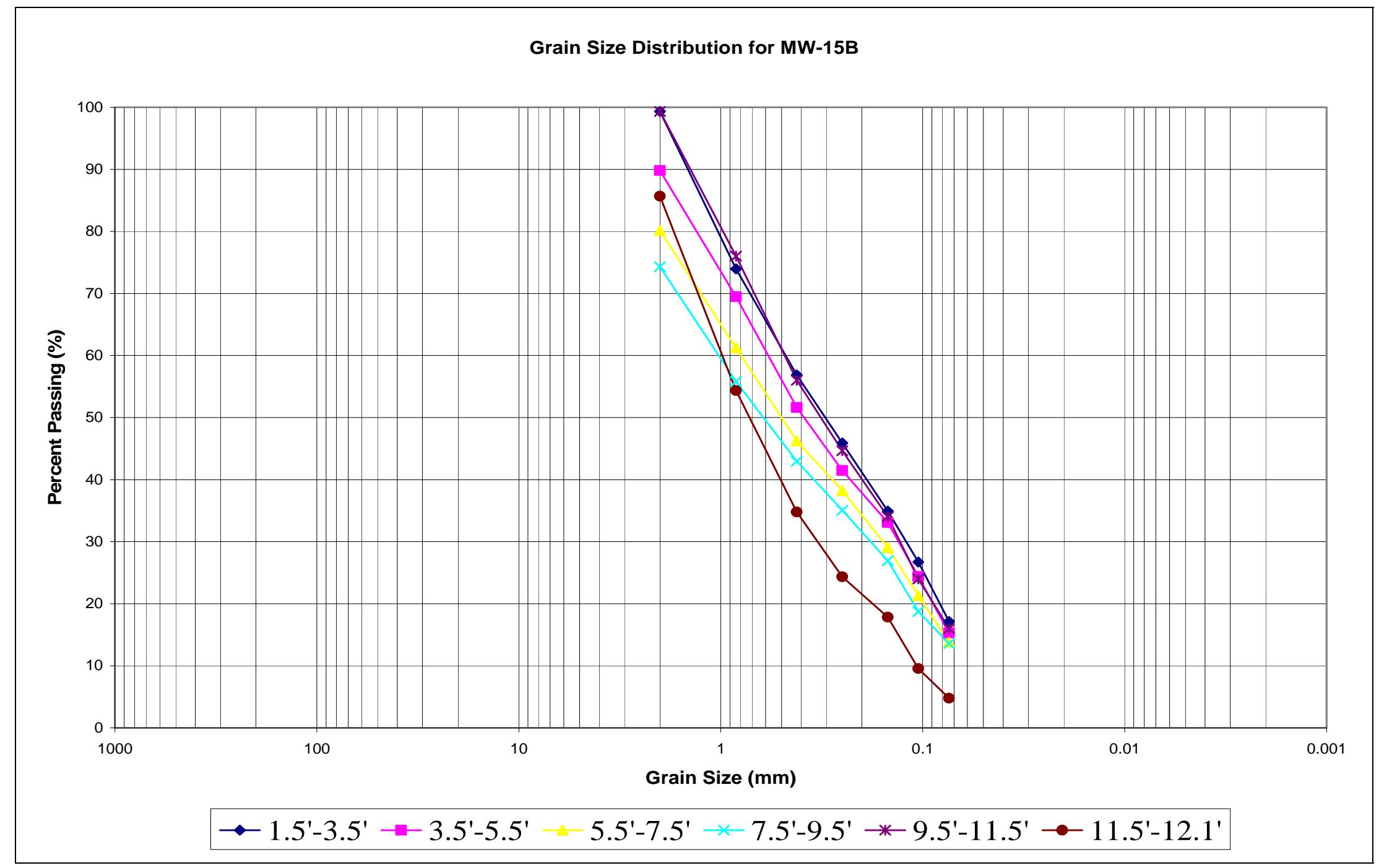

Figure 4-21: Grain Size Distribution Curve for MW-15B. 


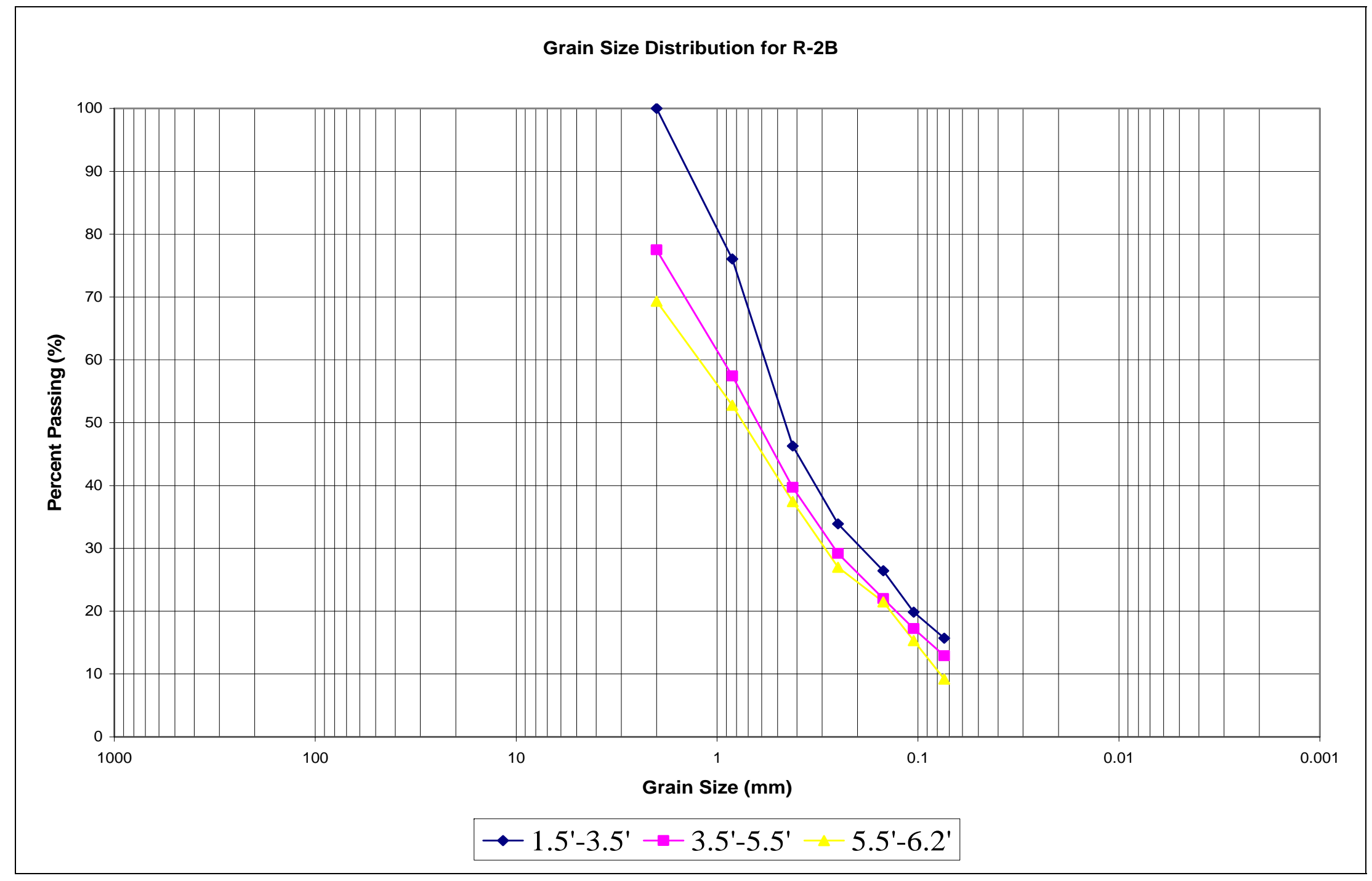

Figure 4-22: Grain Size Distribution Curve for R-2B. 


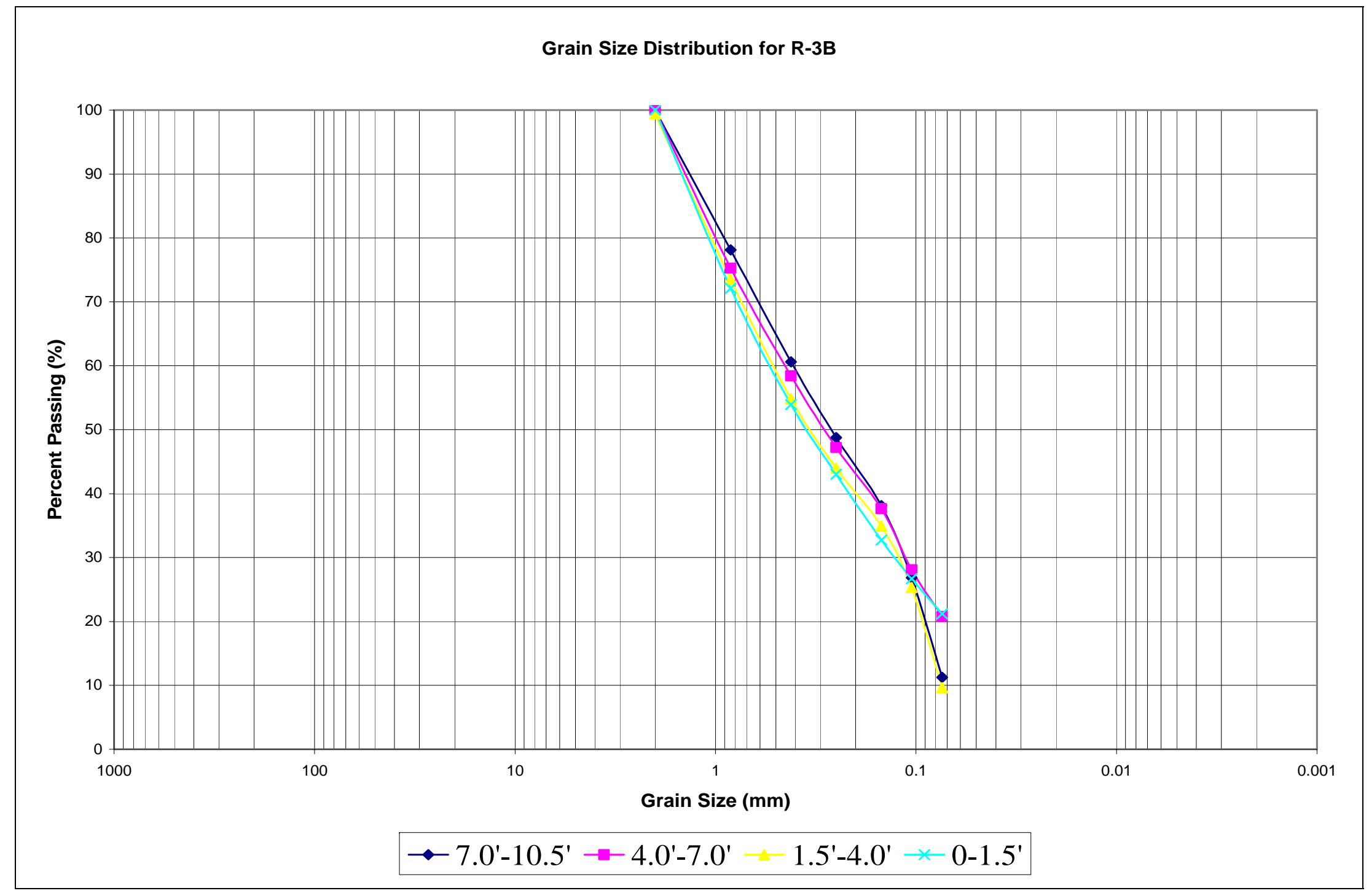

Figure 4-23: Grain Size Distribution Curve for R-3B. 


\subsection{Well Data}

Table 4.7 shows the minimum, maximum, and average readings of the depths and elevations of the piezometric surface of the shallow wells and the automated recorders from June 2001 to June 2004. Table 4.8 shows the minimum, maximum, and average readings of the depths and elevations of the piezometric surface of the deep wells from October 2001 to June 2004. Wells were recorded monthly using a $10 \mathrm{~m}$ Solinst water level meter. A complete set of data may be found in the appendix A. Results from Table 4.7 show that the shallow wells that established the highest piezometric surface elevation were the western-most wells: MW-1, MW-5, MW-9, and MW-13. The wells that exhibited the lowest piezometric surface elevation were the eastern-most shallow monitoring wells. Results from Table 4.8 show the same characteristics of that as the shallow monitoring wells, with the western-most wells exhibiting the maximum elevations and the eastern-most deep monitoring wells exhibiting the lowest piezometric surface elevation.

Table 4-7: Minimum, Maximum, and Average readings of the piezometric ground surface for the shallow wells from June 2001 to June 2004.

\begin{tabular}{|c|c|c|c|c|c|c|}
\hline \multirow{2}{*}{$\begin{array}{c}\text { Shallow } \\
\text { Monitoring } \\
\text { Well }\end{array}$} & \multicolumn{2}{|c|}{ MINIMUM } & \multicolumn{2}{|c|}{ MAXIMUM } & \multicolumn{2}{|c|}{ AVERAGE } \\
\hline & $\begin{array}{c}\text { Elevation } \\
\text { (m) }\end{array}$ & $\begin{array}{l}\text { Depth } \\
(\mathrm{cm})\end{array}$ & $\begin{array}{c}\text { Elevation } \\
\text { (m) }\end{array}$ & $\begin{array}{c}\text { Depth } \\
(\mathrm{cm})\end{array}$ & $\begin{array}{c}\text { Elevation } \\
\text { (m) }\end{array}$ & $\begin{array}{c}\text { Depth } \\
(\mathrm{cm})\end{array}$ \\
\hline MW-1 & 96.9 & -94.6 & 97.6 & -20.6 & 97.2 & -58.8 \\
\hline MW-2 & 95.8 & -103.4 & 96.4 & -36.4 & 95.9 & -86.2 \\
\hline MW-3 & 93.8 & -106.2 & 94.6 & -32.2 & 94.2 & -67.6 \\
\hline MW-4 & 92.9 & -104.3 & 93.5 & -27.9 & 93.1 & -78.6 \\
\hline MW-5 & 97.7 & -102.8 & 98.4 & -29.1 & 98.1 & -77.9 \\
\hline MW-6 & 94.9 & -96.4 & 95.4 & -45.4 & 95.0 & -81.6 \\
\hline MW-7 & 93.7 & -94.0 & 94.3 & -45.0 & 94.1 & -63.4 \\
\hline
\end{tabular}




\begin{tabular}{|l|l|l|l|l|l|l|}
\hline MW-8 & 93.4 & -70.8 & 93.6 & -50.8 & 93.5 & -66.8 \\
\hline MW-9 & 97.2 & -86.0 & 97.5 & -61.8 & 97.4 & -71.4 \\
\hline MW-10 & 95.4 & -95.9 & 96.1 & -26.9 & 95.9 & -49.4 \\
\hline MW-11 & 94.4 & -84.7 & 95.0 & -31.2 & 94.7 & -53.4 \\
\hline MW-12 & 93.5 & -57.9 & 93.6 & -53.9 & 93.6 & -55.4 \\
\hline MW-13 & 96.7 & -78.2 & 97.1 & -35.6 & 96.9 & -55.9 \\
\hline MW-14 & 95.3 & -112.6 & 95.8 & -62.1 & 95.6 & -84.2 \\
\hline MW-15 & 94.5 & -78.3 & 95.0 & -31.3 & 94.7 & -62.4 \\
\hline MW-16 & 96.4 & -104.3 & 96.7 & -70.3 & 96.5 & -92.7 \\
\hline MW-17 & 94.8 & -96.2 & 95.6 & -16.7 & 95.3 & -48.9 \\
\hline MW-18 & 93.0 & -85.9 & 93.8 & -4.4 & 93.4 & -38.7 \\
\hline R-2 & 96 & -62.5 & 96.3 & -37.8 & 96.2 & -45.8 \\
\hline R-3 & 93.8 & -90.2 & 94.1 & -64.0 & 93.9 & -80.5 \\
\hline
\end{tabular}

Table 4-8: Minimum, Maximum, and Average readings of the piezometric ground surface for the deep wells from October 2002 to June 2004.

\begin{tabular}{|c|c|c|c|c|c|c|}
\hline \multirow{2}{*}{$\begin{array}{c}\text { Deep } \\
\text { Monitoring } \\
\text { Wells }\end{array}$} & \multicolumn{2}{|c|}{ MINIMUM } & \multicolumn{2}{c|}{ MAXIMUM } & \multicolumn{2}{c|}{ AVERAGE } \\
\cline { 2 - 7 } & $\begin{array}{c}\text { Elevation } \\
(\mathrm{m})\end{array}$ & $\begin{array}{c}\text { Depth } \\
(\mathrm{cm})\end{array}$ & $\begin{array}{c}\text { Elevation } \\
(\mathrm{m})\end{array}$ & $\begin{array}{c}\text { Depth } \\
(\mathrm{cm})\end{array}$ & $\begin{array}{c}\text { Elevation } \\
(\mathrm{m})\end{array}$ & $\begin{array}{c}\text { Depth } \\
(\mathrm{cm})\end{array}$ \\
\hline MW-3B & 94.5 & -52.1 & 94.7 & -23.6 & 94.6 & -41.4 \\
\hline MW-4B & 92.8 & -121.3 & 93.3 & -66.8 & 93.0 & -97.0 \\
\hline MW-6B & 95.0 & -76.8 & 95.4 & -37.8 & 95.2 & -60.2 \\
\hline MW-7B & 94.1 & -56.8 & 94.4 & -31.8 & 94.2 & -46.8 \\
\hline MW-8B & 92.7 & -147.0 & 93.8 & -38.5 & 93.1 & -107.7 \\
\hline MW-10B & 95.6 & -76.6 & 95.9 & -38.6 & 95.8 & -56.6 \\
\hline MW-13B & 96.5 & -95.3 & 96.8 & -63.3 & 96.7 & -77.3 \\
\hline MW-15B & 94.1 & -123.5 & 94.9 & -48.0 & 94.4 & -100.4 \\
\hline R-2B & 96.4 & -32.3 & 96.7 & -1.3 & 96.6 & -15.4 \\
\hline
\end{tabular}




\subsection{Soil Classification}

Typical results for the Montrose Wetland site soil classification, using the AASHTO classification, are shown below in Table 4-9. The Group Index for each soil is 0. Typical results of the USCS classification are shown in Table 4.10. Figures 4.24 4.38 show a soil profile of the well with a soil description and Atterberg Limits.

Table 4-9: AASHTO Soil Classification for Montrose Wetland Site.

\begin{tabular}{|c|c|c|c|c|c|}
\hline Well & Depth & Classification & Well & Depth & Classification \\
\hline \multirow[t]{4}{*}{ MW-2B } & $0-1.5$ & A-2-4 & MW-10B & $1.5-3.5$ & A-2-4 \\
\hline & $1.5-4.8$ & A-2-4 & & $3.5-5.5$ & A-2-4 \\
\hline & $4.8-6.2$ & A-2-4 & & $5.5-7.5$ & A-1-b \\
\hline & $6.2-9.0$ & A-2-6 & & $7.5-9.5$ & A-1-b \\
\hline \multirow[t]{2}{*}{ MW-3B } & $1.5-3.5$ & A-2-4 & & $9.5-11.2$ & A-2-6 \\
\hline & $7.5-9.0$ & $A-1-b$ & MW-12B & $0-1.5$ & A-2-4 \\
\hline \multirow[t]{5}{*}{ MW-4B } & $1.5-3.5$ & A-2-4 & & $1.5-3.8$ & A-2-4 \\
\hline & $5.5-7.5$ & A-2-4 & & $3.8-9.8$ & A-2-4 \\
\hline & $7.5-9.5$ & A-2-4 & & $9.8-10.5$ & A-2-4 \\
\hline & $9.5-11.5$ & $A-1-b$ & MW-13B & $1.5-3.5$ & A-2-4 \\
\hline & $11.5-13.1$ & A-2-4 & & $3.5-5.5$ & $A-1-b$ \\
\hline \multirow[t]{4}{*}{ MW-5B } & $0-1.5$ & A-3 & & $5.5-7.5$ & A-1-b \\
\hline & $1.5-4.2$ & $A-3$ & & $7.5-9.5$ & A-1-b \\
\hline & $4.2-5.5$ & $A-3$ & & $9.5-11.5$ & A-1-b \\
\hline & $5.5-8.0$ & A-2-7 & & $11.5-13.5$ & A-1-b \\
\hline \multirow[t]{5}{*}{ MW-6B } & $1.5-3.5$ & A-2-4 & & $13.5-14.3$ & A-2-4 \\
\hline & $3.5-5.5$ & A-1-b & MW-14B & $0-1.5$ & A-2-4 \\
\hline & $5.5-7.5$ & A-2-4 & & $1.5-2.9$ & A-2-4 \\
\hline & $7.5-9.5$ & A-3 & & $2.9-5.5$ & A-2-4 \\
\hline & $10.5-12.0$ & A-2-4 & & $5.5-10.1$ & A-2-4 \\
\hline \multirow[t]{5}{*}{ MW-7B } & $1.5-3.5$ & $A-1-b$ & & $10.1-13.5$ & A-2-4 \\
\hline & $3.5-5.5$ & A-2-4 & MW-15B & $1.5-3.5$ & A-2-4 \\
\hline & $5.5-7.5$ & A-2-4 & & $3.5-5.5$ & A-2-4 \\
\hline & $9.5-10.5$ & A-2-4 & & $5.5-7.5$ & A-1-b \\
\hline & $10.5-11.1$ & A-2-4 & & $7.5-9.5$ & A-1-b \\
\hline \multirow[t]{6}{*}{ MW-8B } & $1.5-3.5$ & $A-1-b$ & & $9.5-11.5$ & A-2-4 \\
\hline & $3.5-5.5$ & A-2-4 & & $11.5-12.1$ & A-1-b \\
\hline & $5.5-7.5$ & $A-1-b$ & $\mathrm{R}-2 \mathrm{~B}$ & $1.5-3.5$ & A-2-6 \\
\hline & 7.5-8.8 & A-2-4 & & $3.5-5.5$ & A-2-4 \\
\hline & $8.8-10.8$ & $A-1-b$ & & $5.5-6.2$ & A-2-4 \\
\hline & $10.8-12.0$ & A-2-4 & $\mathrm{R}-3 \mathrm{~B}$ & $0-1.5$ & A-2-4 \\
\hline \multirow[t]{3}{*}{ MW-9B } & $0-1.5$ & A-2-5 & & $1.5-4.0$ & A-3 \\
\hline & $1.5-4.5$ & $A-1-b$ & & $4.0-7.0$ & A-2-4 \\
\hline & $4.5-8.8$ & A-1-b & & $7.0-10.5$ & A-2-4 \\
\hline
\end{tabular}


Table 4-10: USCS Soil Classification for Montrose Wetland Site.

\begin{tabular}{|c|c|c|}
\hline Well & Depth & Classification \\
\hline \multirow[t]{4}{*}{$\mathrm{MW}-2 \mathrm{~B}$} & $0-1.5$ & SM \\
\hline & $1.5-4.8$ & SP-SC \\
\hline & $4.8-6.2$ & SP-SC \\
\hline & $6.2-9.0$ & SP-SC \\
\hline \multirow[t]{2}{*}{ MW-3B } & $1.5-3.5$ & SP-SC \\
\hline & $7.5-9.0$ & SW-SM \\
\hline \multirow[t]{5}{*}{ MW-4B } & $1.5-3.5$ & SP-SC \\
\hline & $5.5-7.5$ & SM-SC \\
\hline & $7.5-9.5$ & SM \\
\hline & $9.5-11.5$ & SW-SM \\
\hline & $11.5-13.1$ & SW-SC \\
\hline \multirow[t]{4}{*}{ MW-5B } & $0-1.5$ & SP \\
\hline & $1.5-4.2$ & SP \\
\hline & $4.2-5.5$ & SP \\
\hline & $5.5-8.0$ & SP-SC \\
\hline \multirow[t]{5}{*}{ MW-6B } & $1.5-3.5$ & SP-SC \\
\hline & $3.5-5.5$ & SM-SC \\
\hline & $5.5-7.5$ & SM-SC \\
\hline & $7.5-9.5$ & SP \\
\hline & $10.5-12.0$ & SW-SC \\
\hline \multirow[t]{5}{*}{ MW-7B } & $1.5-3.5$ & SM-SC \\
\hline & $3.5-5.5$ & SC \\
\hline & $5.5-7.5$ & SC \\
\hline & $9.5-10.5$ & SC \\
\hline & $10.5-11.1$ & SP-SC \\
\hline \multirow[t]{6}{*}{ MW-8B } & $1.5-3.5$ & SM-SC \\
\hline & $3.5-5.5$ & SM-SC \\
\hline & $5.5-7.5$ & SM-SC \\
\hline & $7.5-8.8$ & SM-SC \\
\hline & $8.8-10.8$ & SM-SC \\
\hline & $10.8-12.0$ & SP \\
\hline \multirow[t]{4}{*}{ MW-9B } & $0-1.5$ & SP-SC \\
\hline & $1.5-4.5$ & SP \\
\hline & $4.5-8.8$ & SC \\
\hline & $8.8-10.7$ & SW \\
\hline
\end{tabular}

\begin{tabular}{|c|c|c|}
\hline Well & Depth & Classification \\
\hline \multirow[t]{5}{*}{ MW-10B } & $1.5-3.5$ & SP-SC \\
\hline & $3.5-5.5$ & SC-SM \\
\hline & $5.5-7.5$ & SP-SM \\
\hline & $7.5-9.5$ & SP \\
\hline & $9.5-11.2$ & $\mathrm{SP}$ \\
\hline \multirow[t]{4}{*}{ MW-12B } & $0-1.5$ & SC \\
\hline & $1.5-3.8$ & SC \\
\hline & $3.8-9.8$ & SM-SC \\
\hline & $9.8-10.5$ & SW-SC \\
\hline \multirow[t]{7}{*}{ MW-13B } & $1.5-3.5$ & SM-SC \\
\hline & $3.5-5.5$ & SM-SC \\
\hline & $5.5-7.5$ & SM-SC \\
\hline & $7.5-9.5$ & SW-SM \\
\hline & $9.5-11.5$ & SW-SC \\
\hline & $11.5-13.5$ & SM-SC \\
\hline & $13.5-14.3$ & SW \\
\hline \multirow[t]{5}{*}{ MW-14B } & $0-1.5$ & SC \\
\hline & $1.5-2.9$ & SC \\
\hline & $2.9-5.5$ & SM \\
\hline & $5.5-10.1$ & SC \\
\hline & $10.1-13.5$ & SM-SC \\
\hline \multirow[t]{6}{*}{ MW-15B } & $1.5-3.5$ & SC \\
\hline & $3.5-5.5$ & SM-SC \\
\hline & $5.5-7.5$ & SM \\
\hline & $7.5-9.5$ & SM-SC \\
\hline & $9.5-11.5$ & SC \\
\hline & $11.5-12.1$ & SW-SM \\
\hline \multirow[t]{3}{*}{$\mathrm{R}-2 \mathrm{~B}$} & $1.5-3.5$ & SC \\
\hline & $3.5-5.5$ & $\mathrm{SC}$ \\
\hline & $5.5-6.2$ & SP-SC \\
\hline \multirow[t]{4}{*}{$\mathrm{R}-3 \mathrm{~B}$} & $0-1.5$ & SC \\
\hline & $1.5-4.0$ & SP-SC \\
\hline & $4.0-7.0$ & SM-SC \\
\hline & $7.0-10.5$ & SM-SC \\
\hline
\end{tabular}




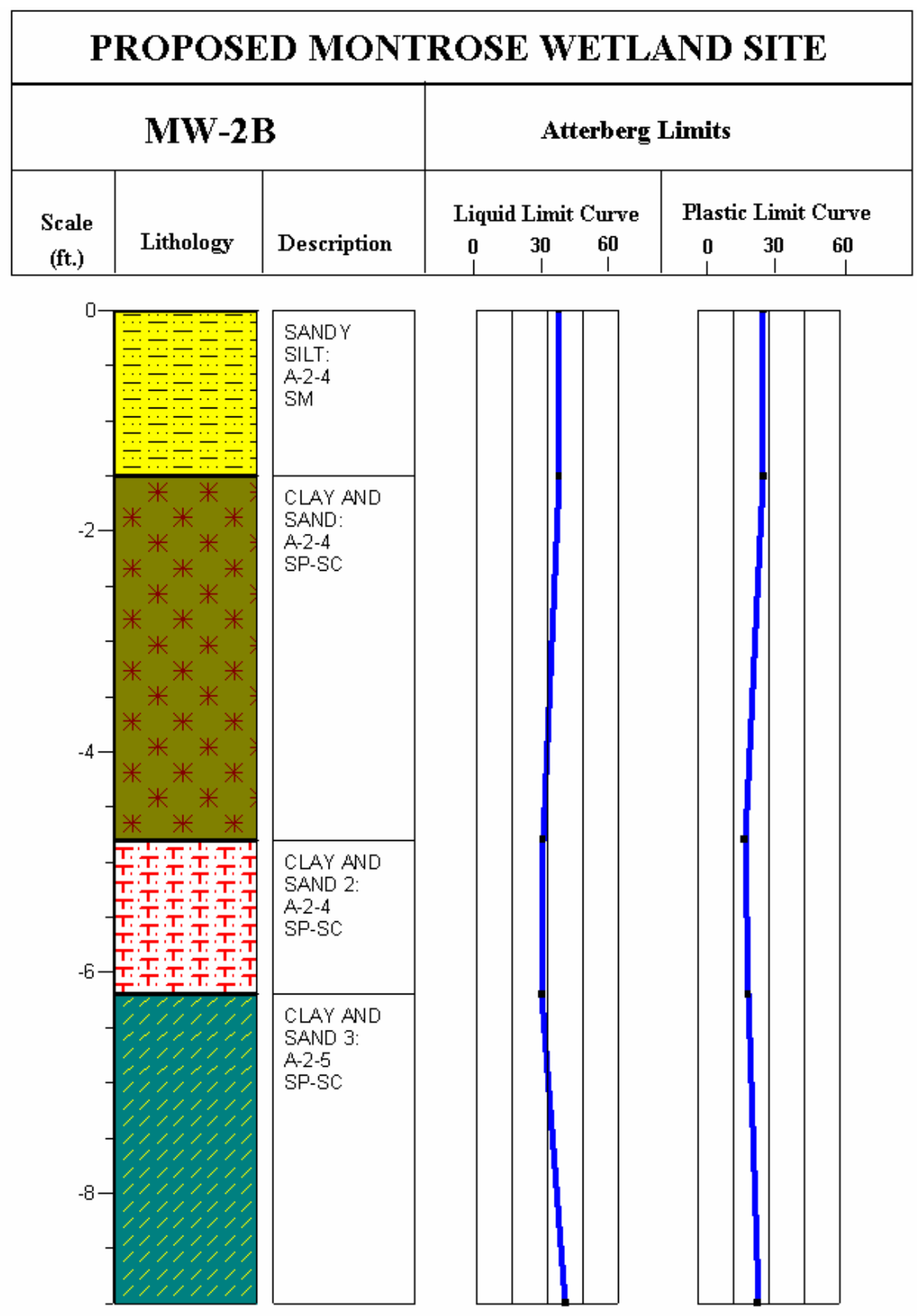

Figure 4-24: Profile of MW-2B with soil description and Atterberg Limits graph. 


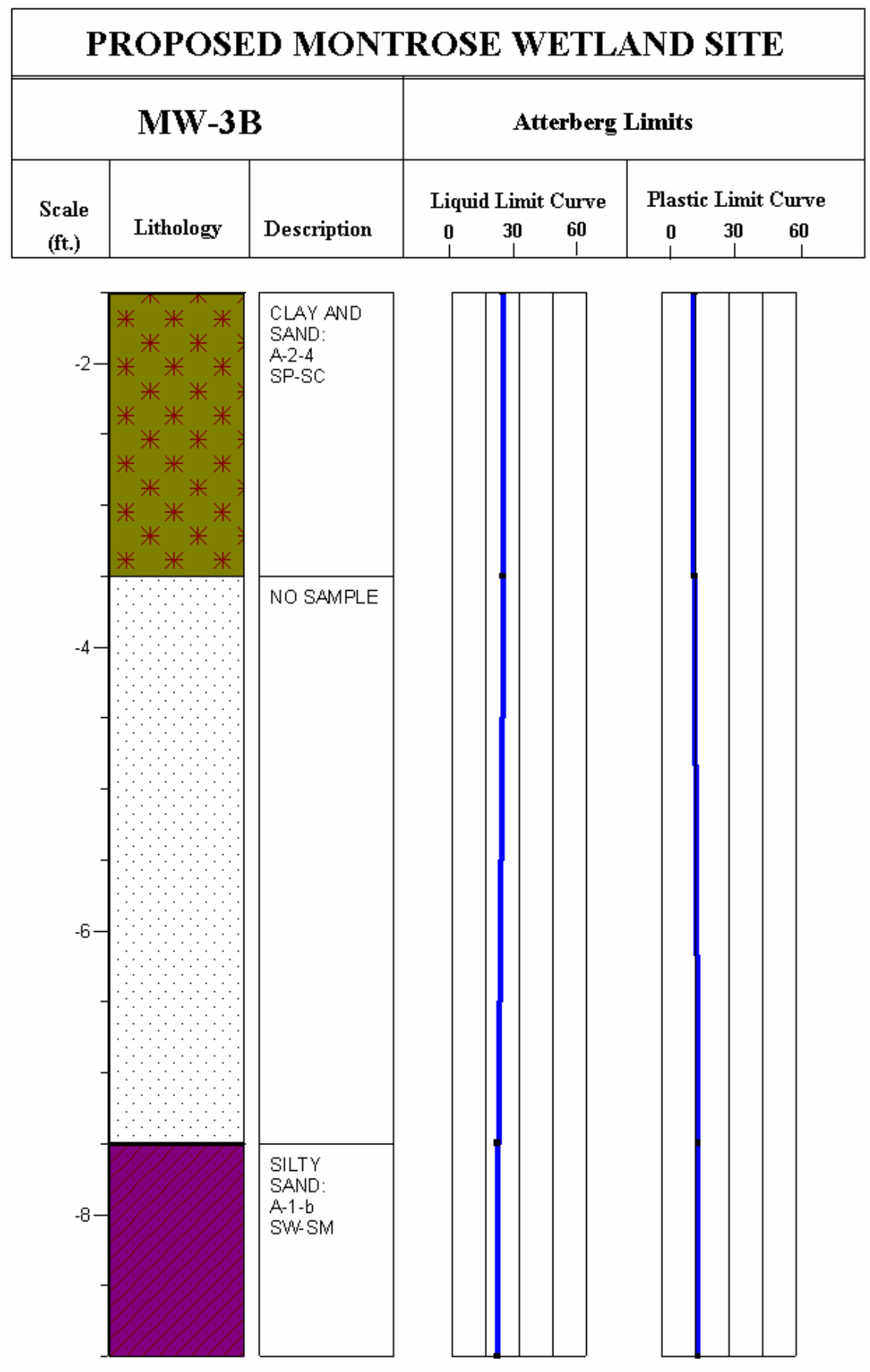

Figure 4-25: Profile of MW-3B with soil description and Atterberg Limits graph. 


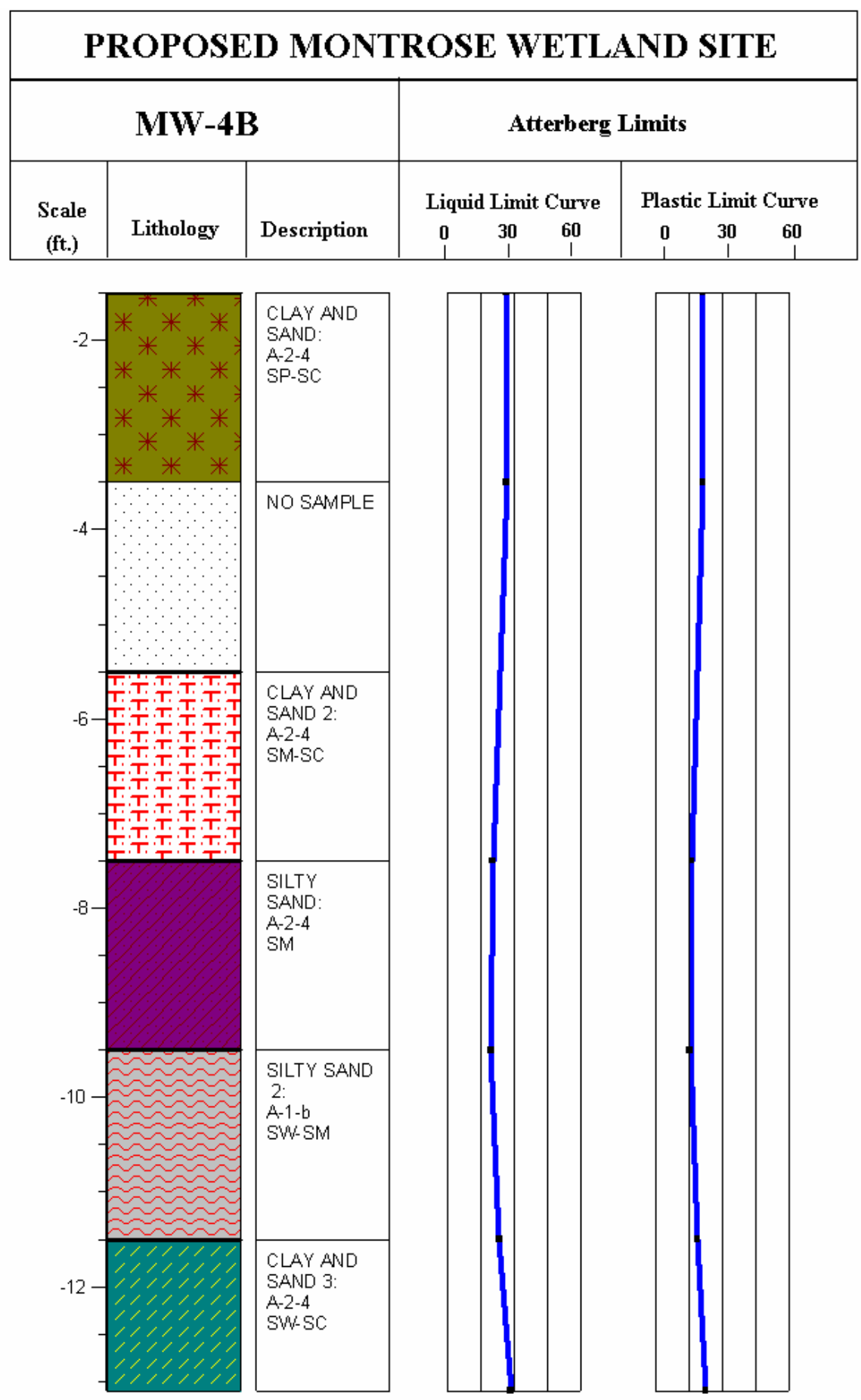

Figure 4-26: Profile of MW-4B with soil description and Atterberg Limits graph. 


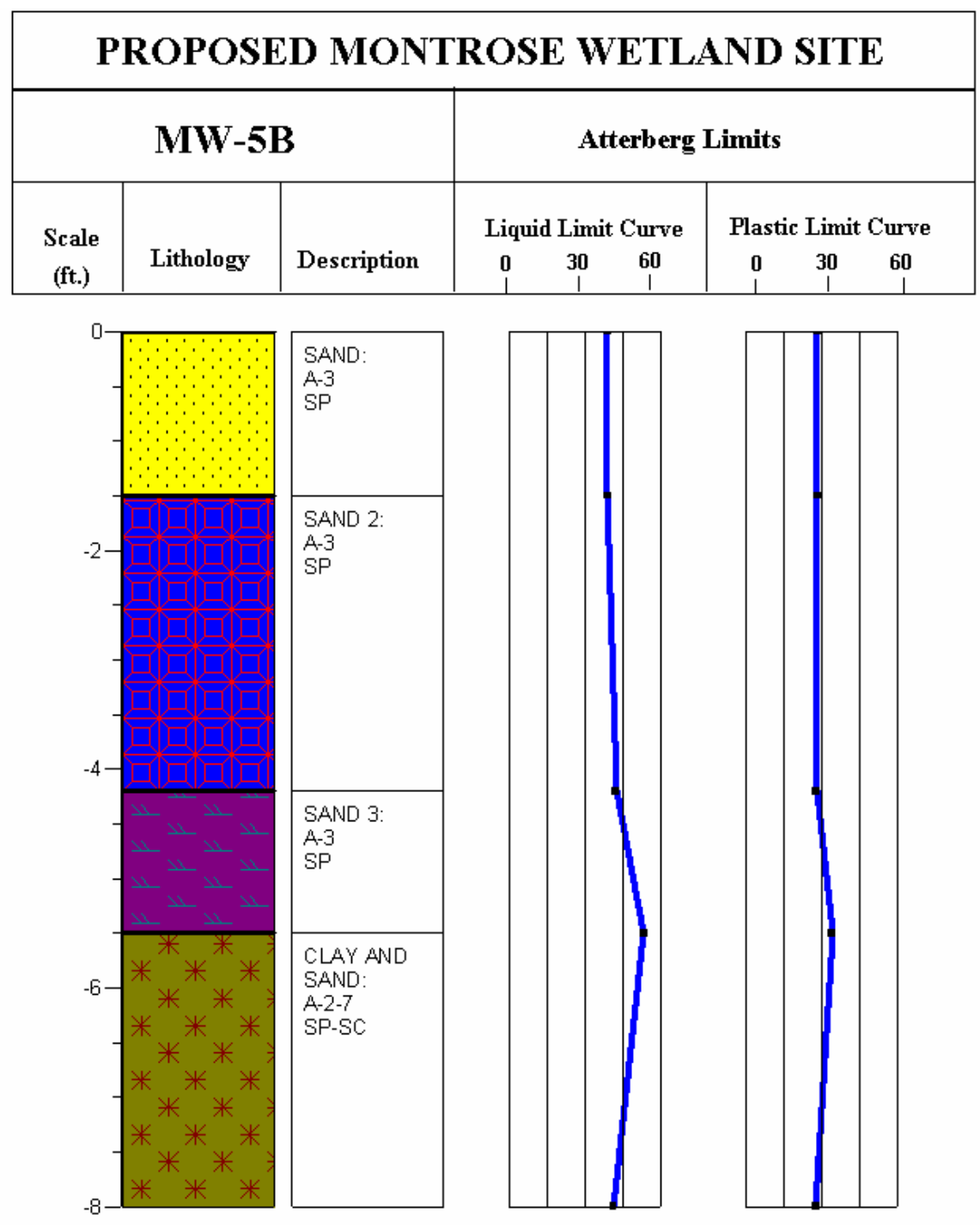

Figure 4-27: Profile of MW-5B with soil description and Atterberg Limits graph. 


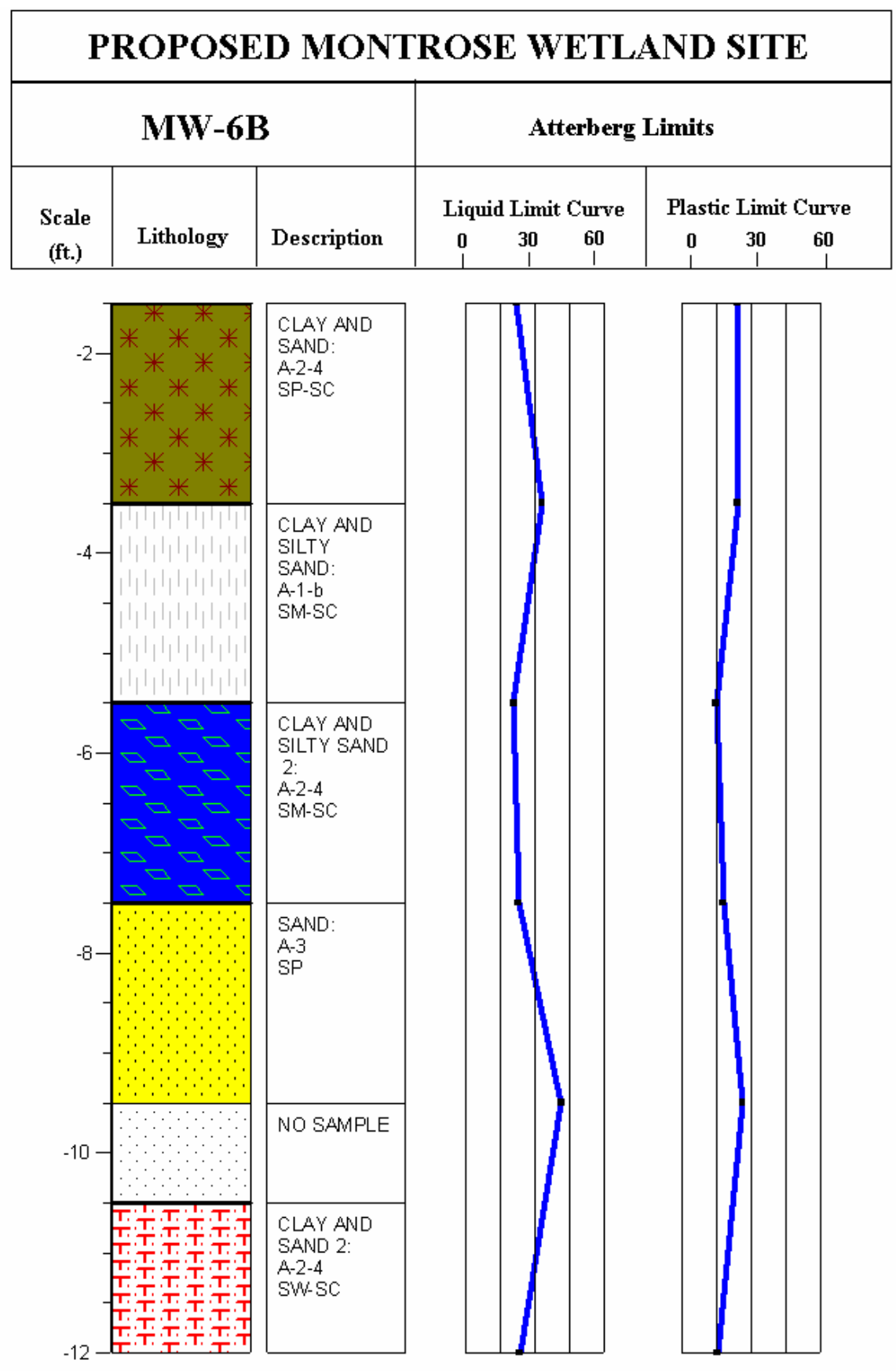

Figure 4-28: Profile of MW-6B with soil description and Atterberg Limits graph. 


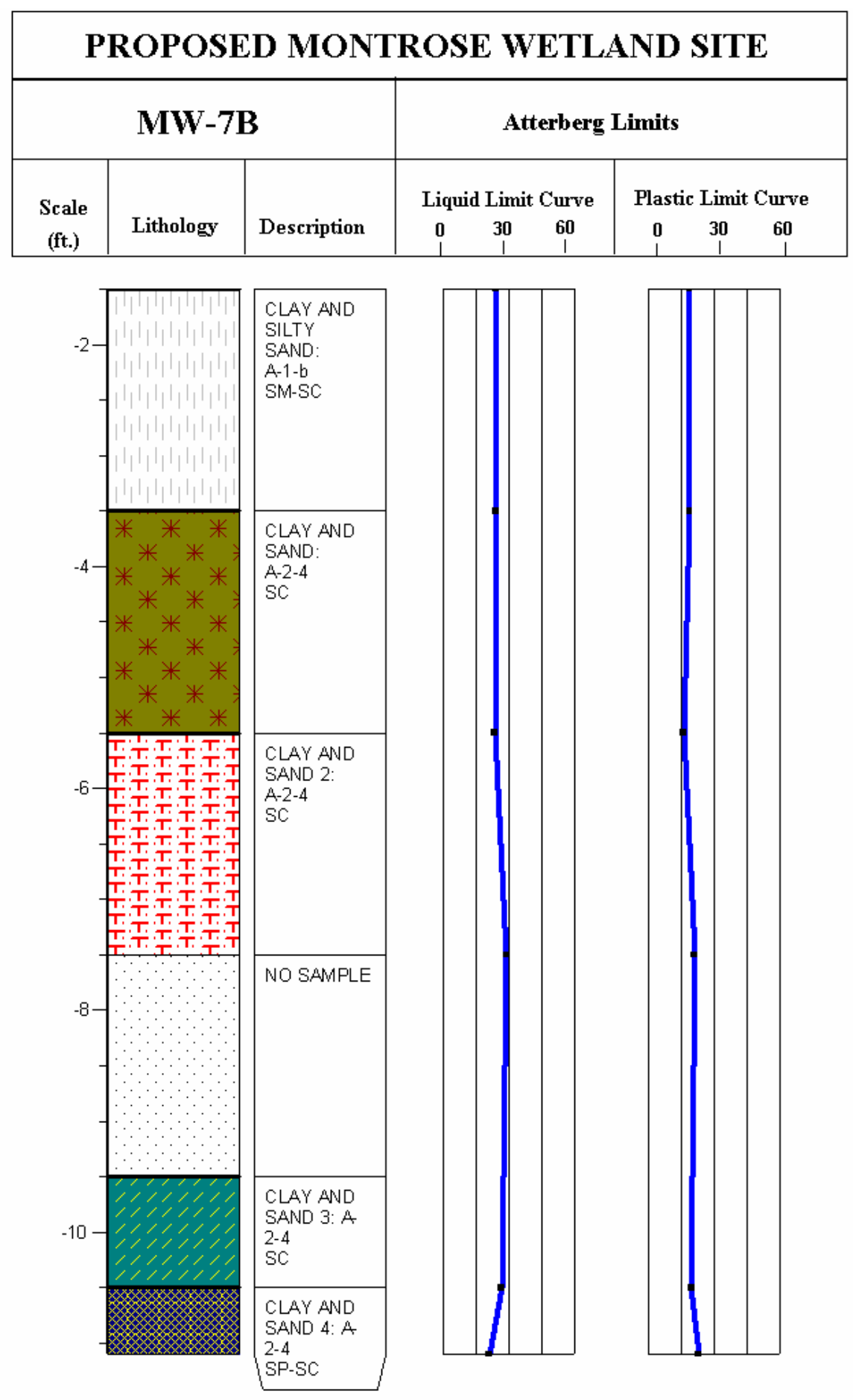

Figure 4-29: Profile of MW-7B with soil description and Atterberg Limits graph. 




Figure 4-30: Profile of MW-8B with soil description and Atterberg Limits graph. 


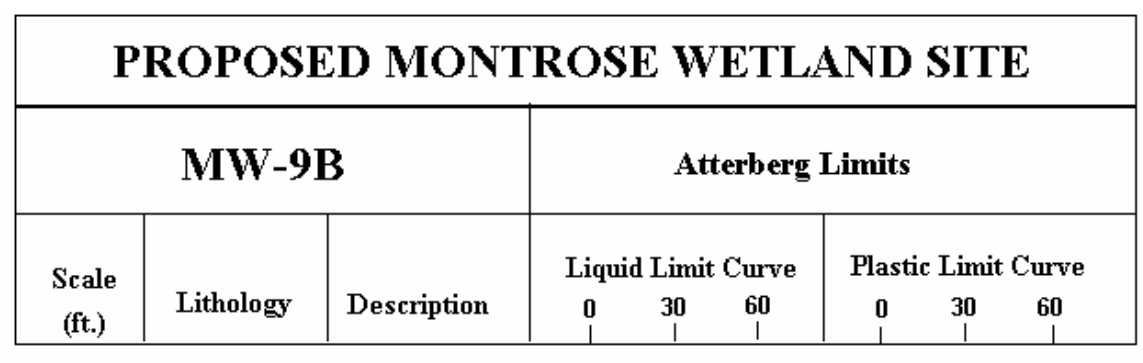

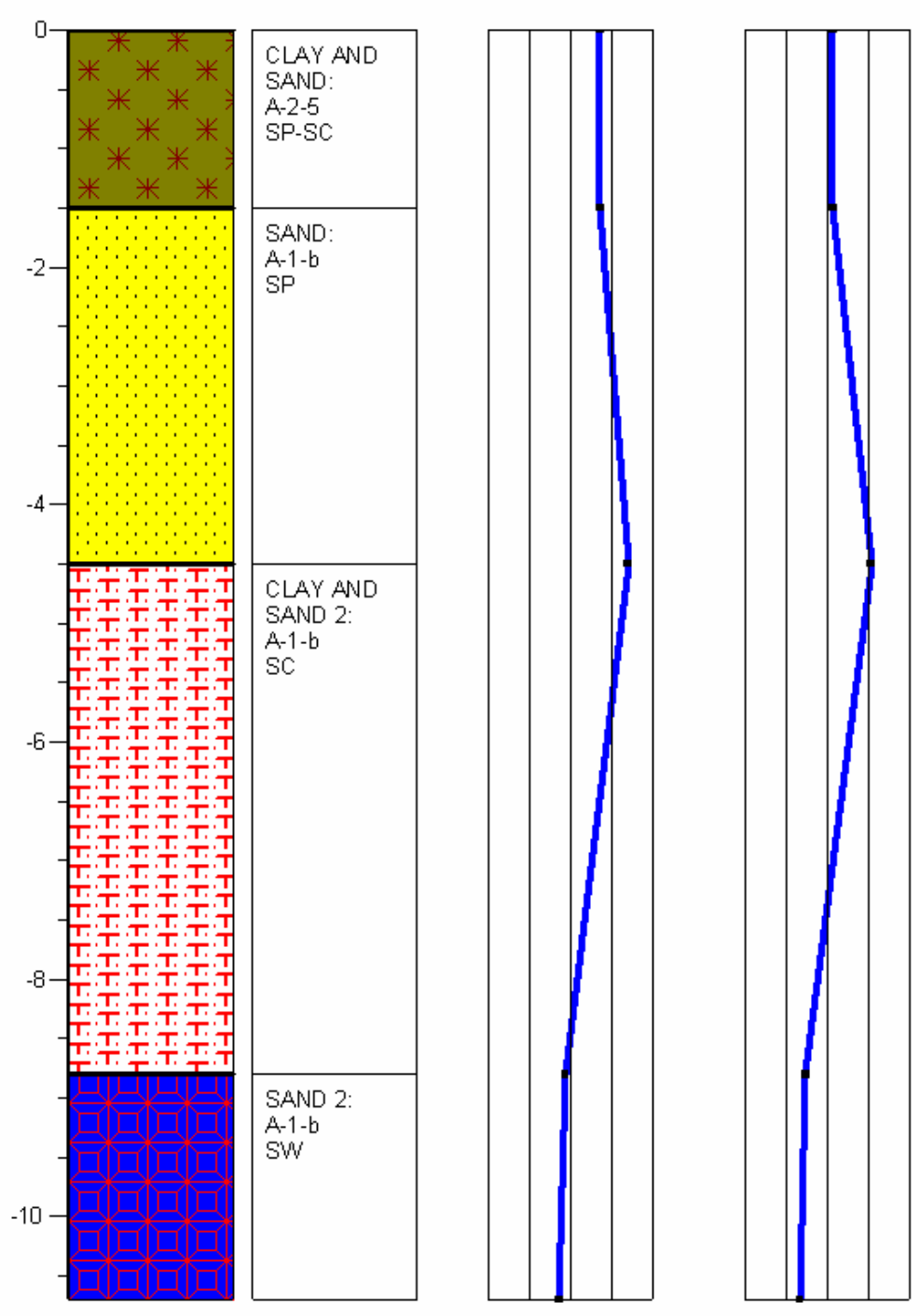

Figure 4-31: Profile of MW-9B with soil description and Atterberg Limits graph. 


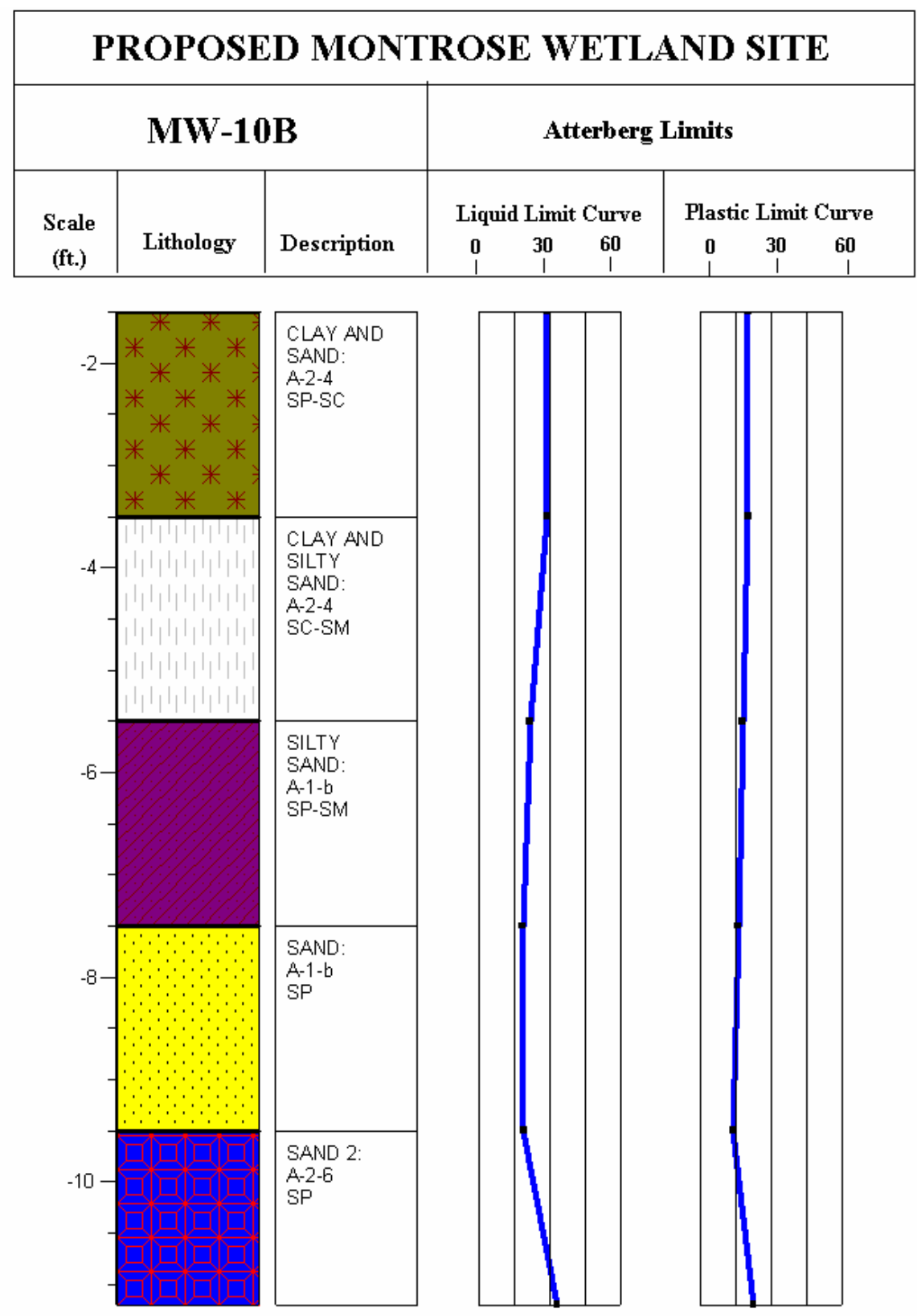

Figure 4-32: Profile of MW-10B with soil description and Atterberg Limits graph. 


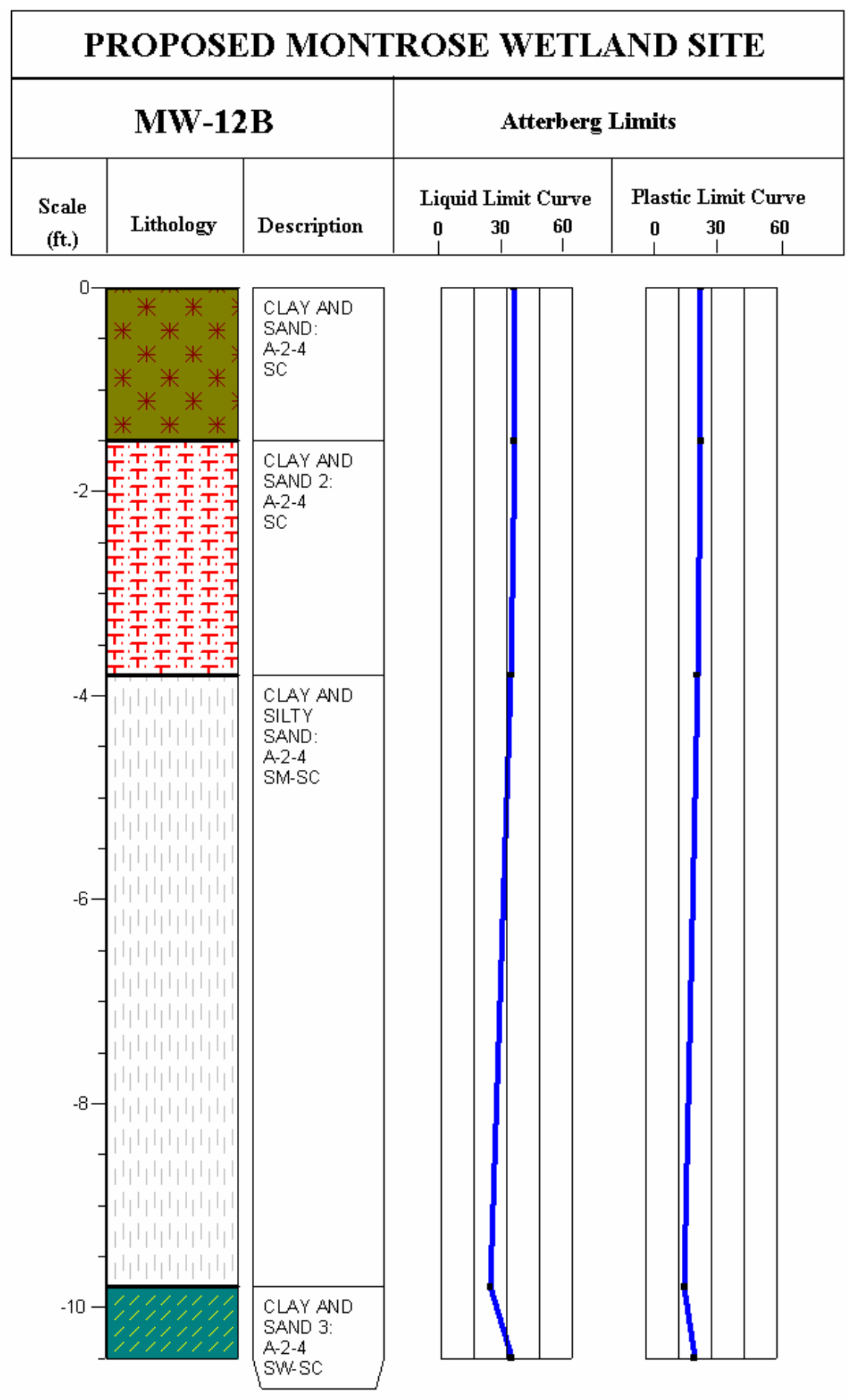

Figure 4-33: Profile of MW-12B with soil description and Atterberg Limits graph. 


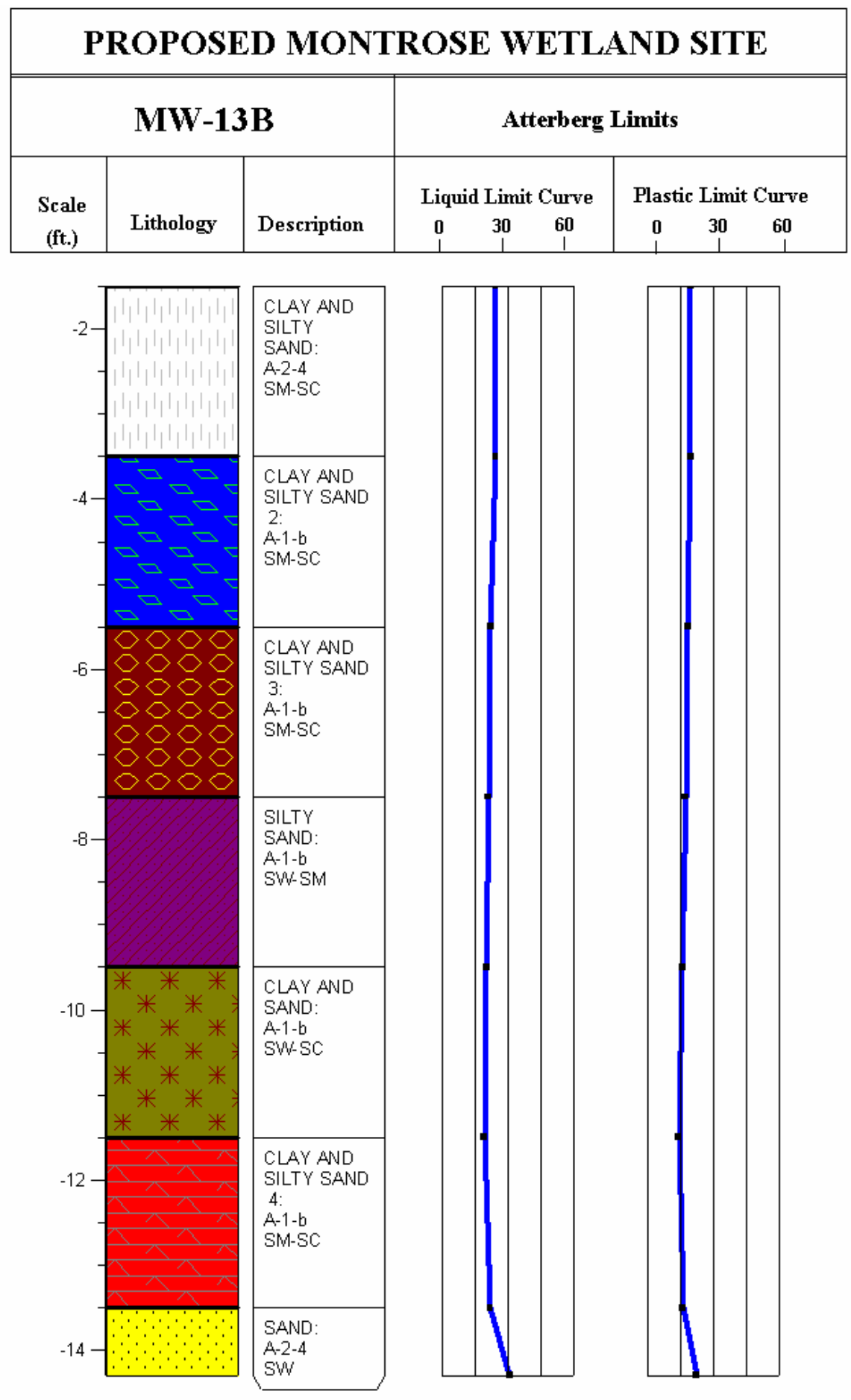

Figure 4-34: Profile of MW-13B with soil description and Atterberg Limits graph. 


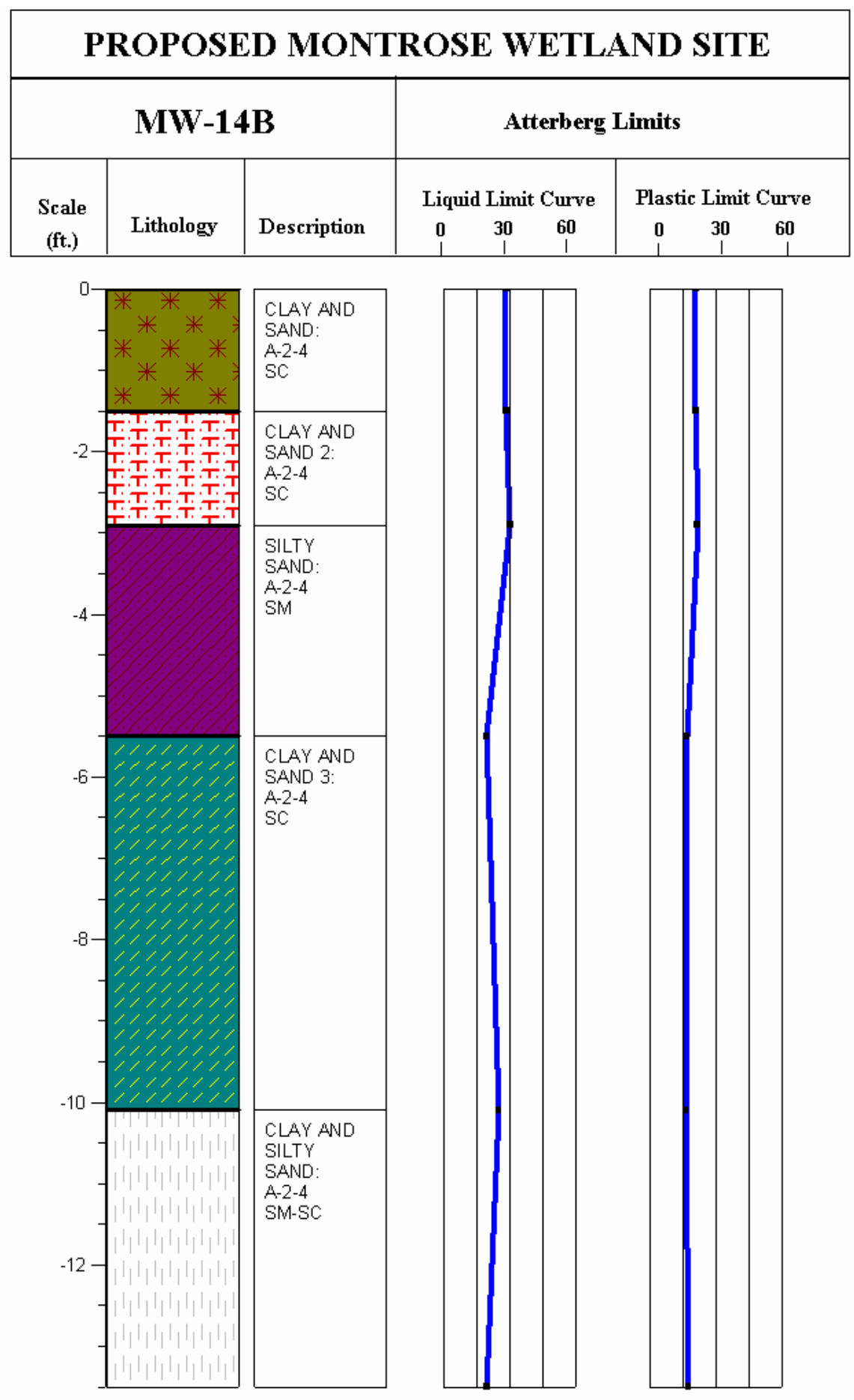

Figure 4-35: Profile of MW-14B with soil description and Atterberg Limits graph. 


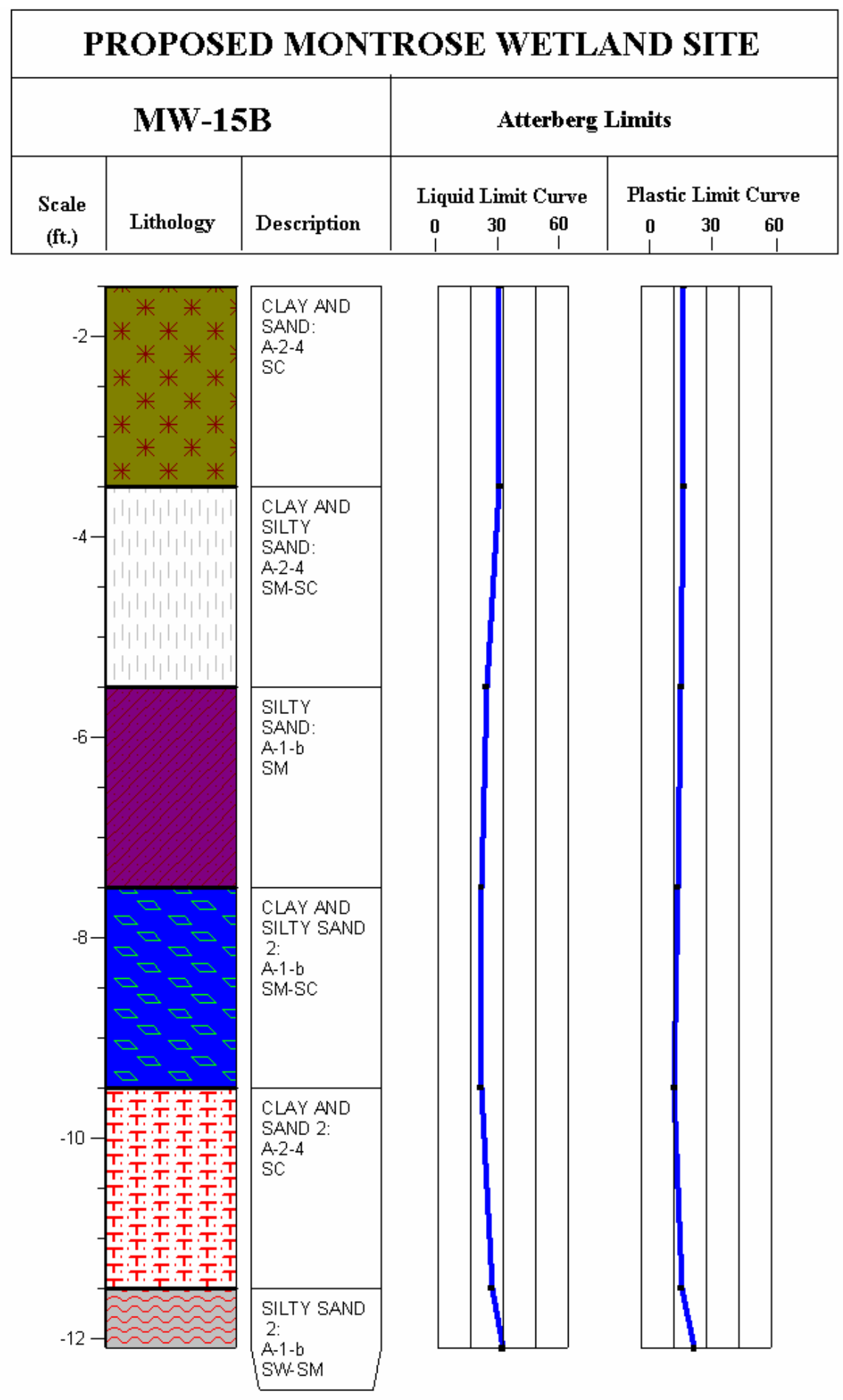

Figure 4-36: Profile of MW-15B with soil description and Atterberg Limits graph. 


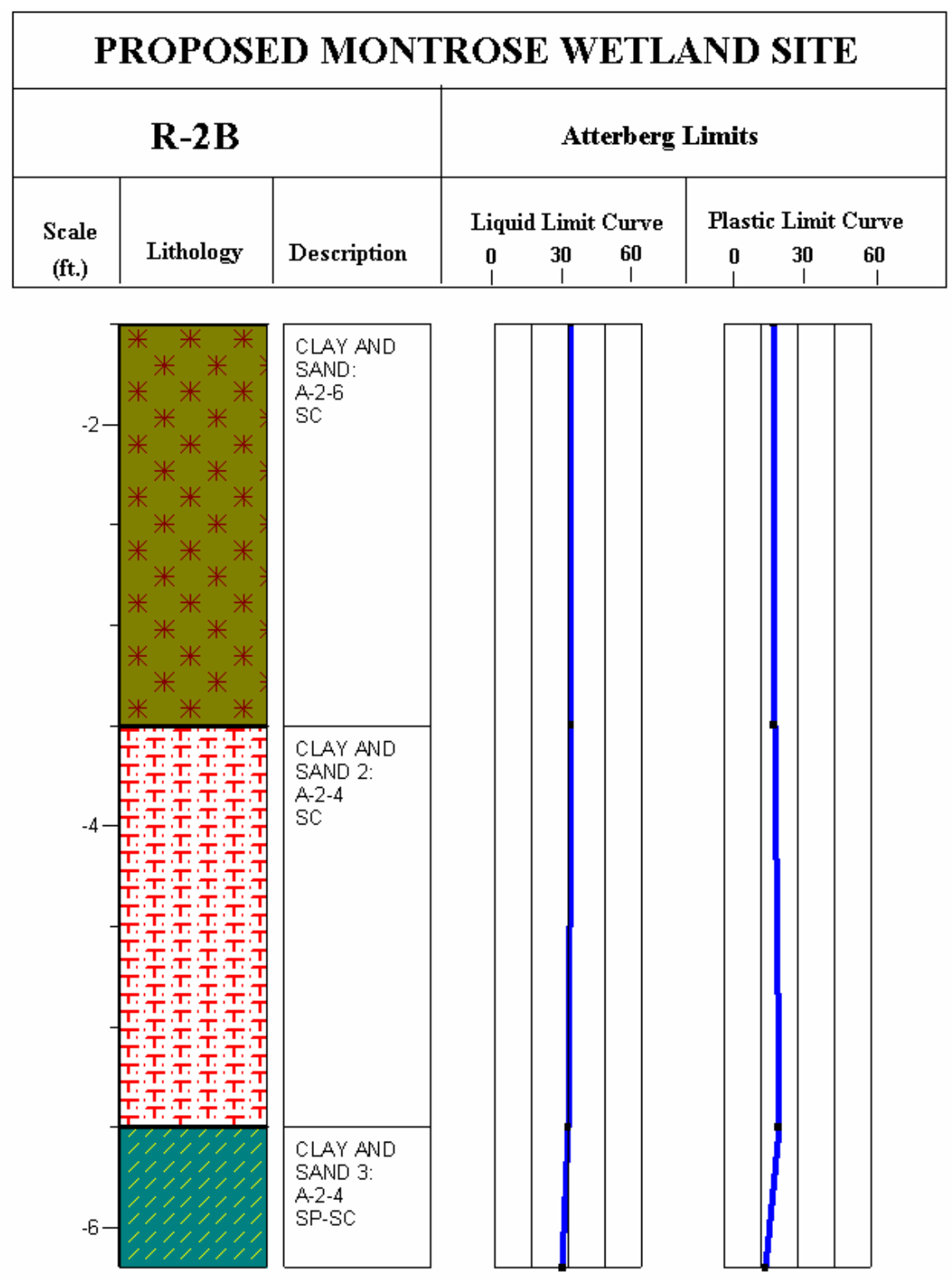

Figure 4-37: Profile of R-2B with soil description and Atterberg Limits graph. 


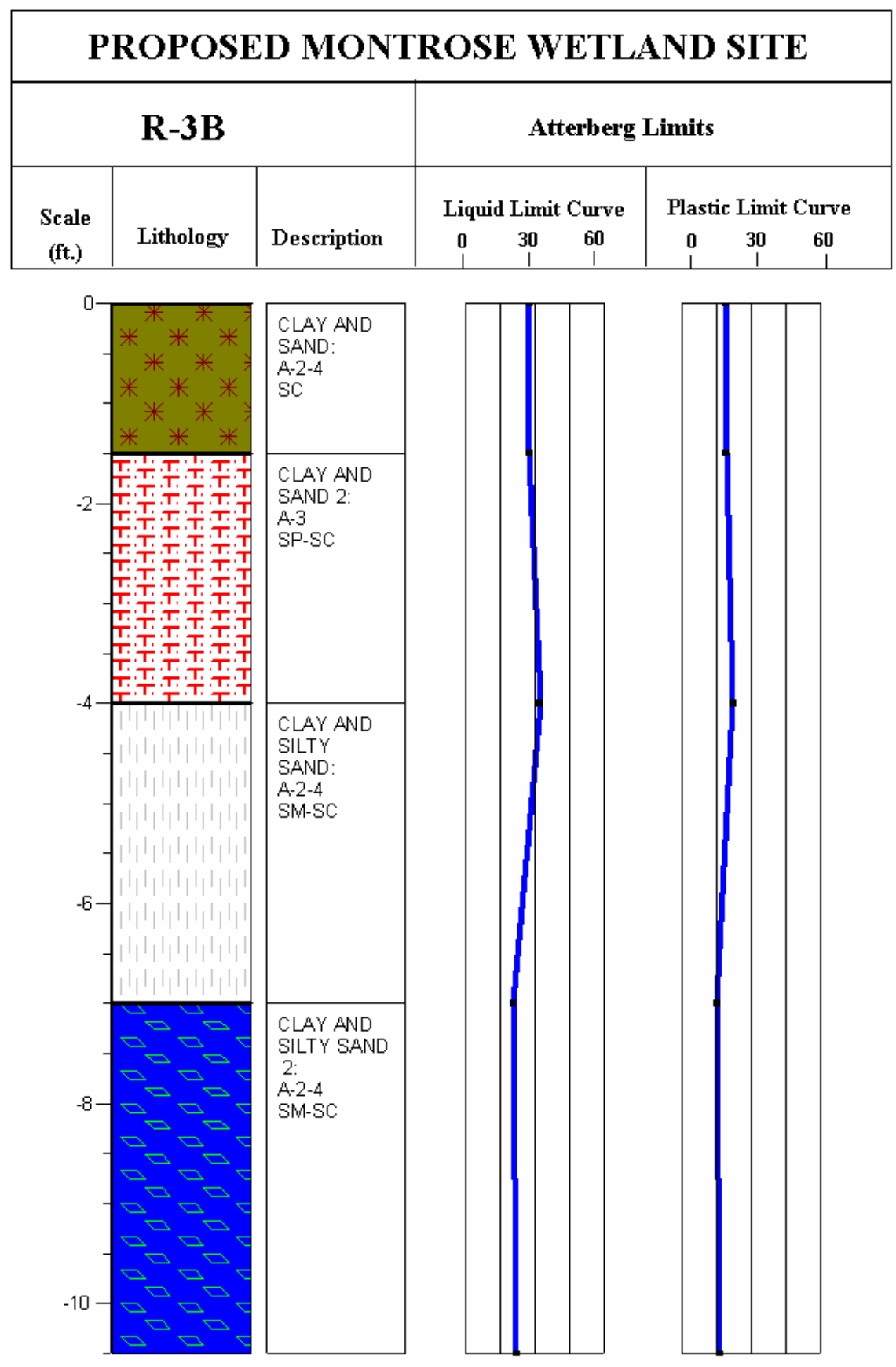

Figure 4-38: Profile of R-3B with soil description and Atterberg Limits graph. 


\section{CHAPTER 5: SUMMARY AND CONCLUSIONS}

\subsection{Engineering of a Wetland}

The definition of a wetland has many different interpretations. The reason for the ambiguity of a wetland definition is the fact that most wetlands exhibit characteristics of both aquatic and terrestrial ecosystems. Wetlands do have certain characteristics: (1) the presence of water at or near the surface; (2) soils that differ from those of adjacent uplands; and (3) vegetation adapted to wet conditions (Mitsch and Gosselink 2000). A habitat with at least one of these characteristics may be classified as a wetland. One of the goals for this project is to create a guideline for a wetland system through the implementation of a hydraulic barrier.

To properly create an engineered wetland, many different factors must be taken into consideration. The existing hydrology, the properties of the soil at the site, and the ecological factors are a few of the considerations studied. This project consisted of determining soil properties and monitoring existing hydrology. An engineered wetland should be designed for minimum maintenance (Mitsch and Gosselink 2000). Thus a new approach to wetland creation can be considered for this site. This process consists of the placement of a vertical hydraulic barrier that can restrict the subsurface flow and raise the ground water table to the surface to produce wetland conditions. The installation of the barrier will require minimal excavation, as opposed to other traditional methods that require excavation across the entire site. Past methods require the installation of a horizontal hydraulic barrier throughout the entirety of the construction site. The only excavation needed will be a narrow trench line for placement of the hydraulic barrier. 
The amount of area that may be disturbed is significantly less than that of the other methods and thus the amount of time necessary for succession of the area from upland habitat to wetland habitat may be minimal (Messenger 2003).

There are many different vertical hydraulic barriers that may be applied for wetland mitigation projects. A slurry wall, sheet piling, compacted clay liners, or a geomembrane liner may all be used effectively as a vertical hydraulic barrier, but with high costs and tedious installation accompanied with these traditional methods, a different approach may be taken. A geosynthetic clay liner (GCL) may be used as a hydraulic barrier. The GCL consists of a Bentonite clay sandwiched between two layers of geosynthetic material. It is recommended that the hydraulic conductivity, $\mathrm{k}$, of the barrier be one hundred times more than that of the existing soil. The typical $\mathrm{k}$ of the Bentonite soil used in a GCL is 1 to $5 \times 10^{-11} \mathrm{~cm} / \mathrm{s}$ (Phillips and Eberle 2001) and the average $\mathrm{k}$ of the site is $3.45 \times 10^{-7} \mathrm{~cm} / \mathrm{s}$. The cost and maintenance of using a GCL material is relatively lower than that of other methods, and the installation process is much faster. Geosynthetic clay liners offer a logical and competitive alternative to the use of compacted clay liners (Koerner 1990).

Placement of the hydraulic barrier will depend upon the hydrology of ground water system at the site. Shallow monitoring wells and deep monitoring wells were installed at the site to determine the characteristics of the ground water system. The set of wells have been monitored monthly since their installation. The characteristics of the ground water system are pertinent in determining the flow patterns of the subsurface water. The placement of the hydraulic barrier can be determined based upon the flow patterns of the ground water system. The depth of the ground water surface was 
determined from the average piezometric surface elevation data recorded monthly (Messenger 2003). Figure 5.1 shows the assumed flow pattern for the shallow monitoring wells and Figure 5.2 shows the assumed flow patterns for the deep monitoring wells. The groundwater flow patterns were determined by calculating the hydraulic gradient between adjacent shallow monitoring devices using average piezometric surface elevation data (Messenger 2003).

The flow pattern of the ground water system shows that the flow travels towards Laurel Run, west to east, as shown in Figures 5.1 and 5.2. Thus placing a vertical hydraulic barrier along the streamline (Figure 5.3) can create conditions favorable to that of a wetland system by impeding the flow of the subsurface water. This method would require approximately 2,000 linear feet of the hydraulic barrier. Installing barriers along the body of the site, to generate three cells (Figure 5.4), can provide a more ecological approach to implement the wetland conditions, by creating a larger surface area of wetland conditions through the saturation of the majority of the soil at the project site. Thus, the benefits of wetland functions, such as water quality, water supply, flood protection, erosion control, and fish and wildlife habitats, may be derived more efficiently. This method would require approximately 3,500 linear feet of the hydraulic barrier. Using this approach of multiple cells can provide for a better success rate. Dividing the site into three different cells can increase the probability of the entire site exhibiting wetland conditions, as opposed to the area only along the streamline. This can be achieved by retaining the ground water at numerous locations through the use of the vertical hydraulic barrier and can cause the water to rise to the ground surface across the majority of the site. A spillway may be created along predetermined sections of the 
trench line to allow any excess surface water to flow into the adjacent cell. Creation of wetland characteristics are dependent upon the existing ground water level rising to the surface due to the implementation of a vertical barrier and from any additional rainfall or surface water inflow experienced at the site. Figure 5.5 and Figure 5.6 show the amount of rainfall that was recorded in the automated recording wells, R-2 and R-3, from March 2001 to September 2001. Graphs containing the results from the monthly well readings which show the depth of the groundwater surface at each well are shown in Figures 5.7 through 5.9 for the shallow wells and in Figure 5.10 for the deep wells. Additional graphs for the groundwater level at each individual well can be found in the appendix C. Monthly well readings that are prior to January 2003 were recorded by B. Messenger (Messenger 2003). 




Figure 5-1: Groundwater flow patterns based on the average piezometric surface elevation data in the shallow monitoring wells and the automated recorders (Messenger 2003). 


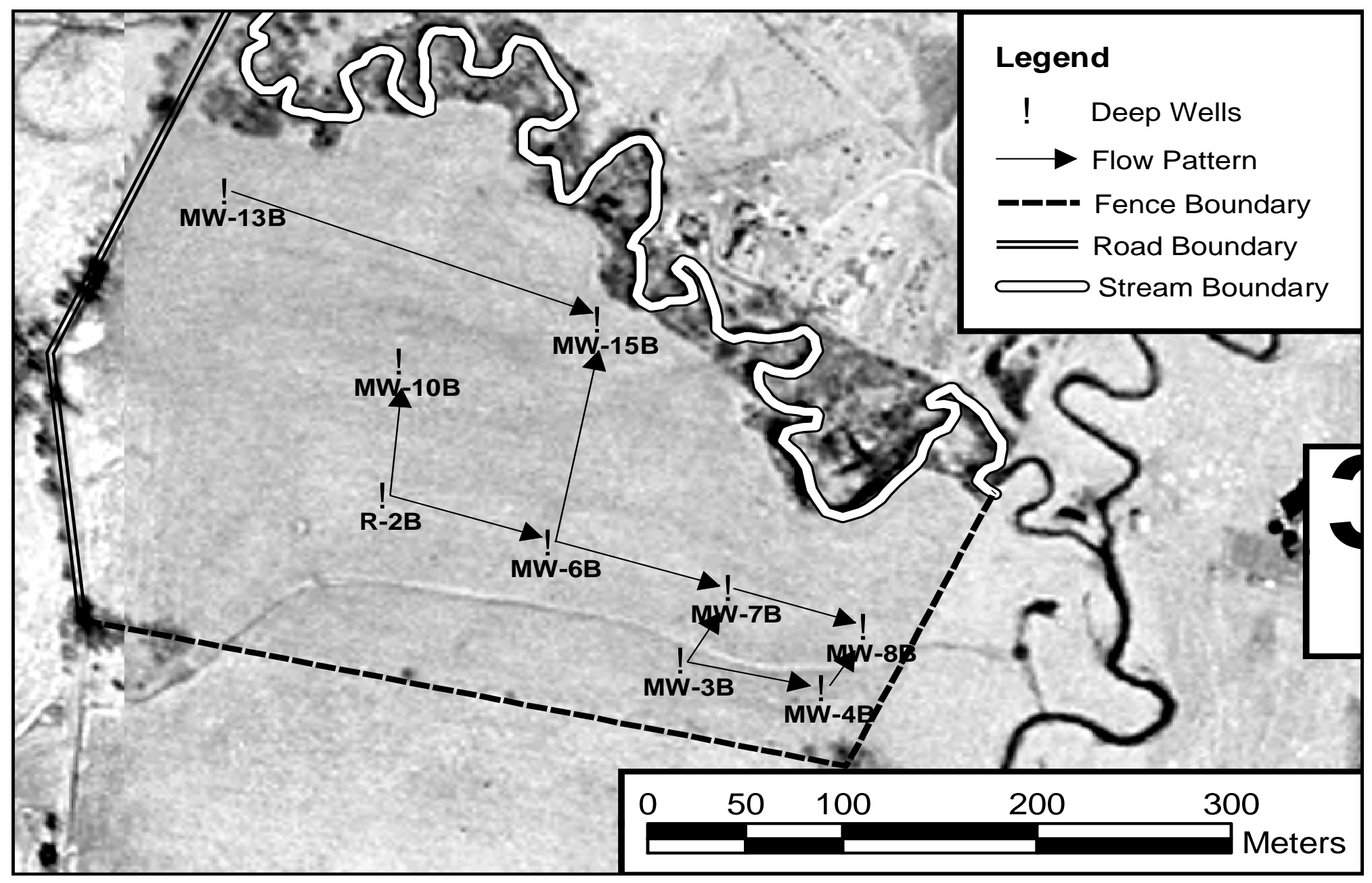

Figure 5-2: Groundwater flow patterns based on the average piezometric surface elevation data in the deep monitoring wells (Messenger 2003). 


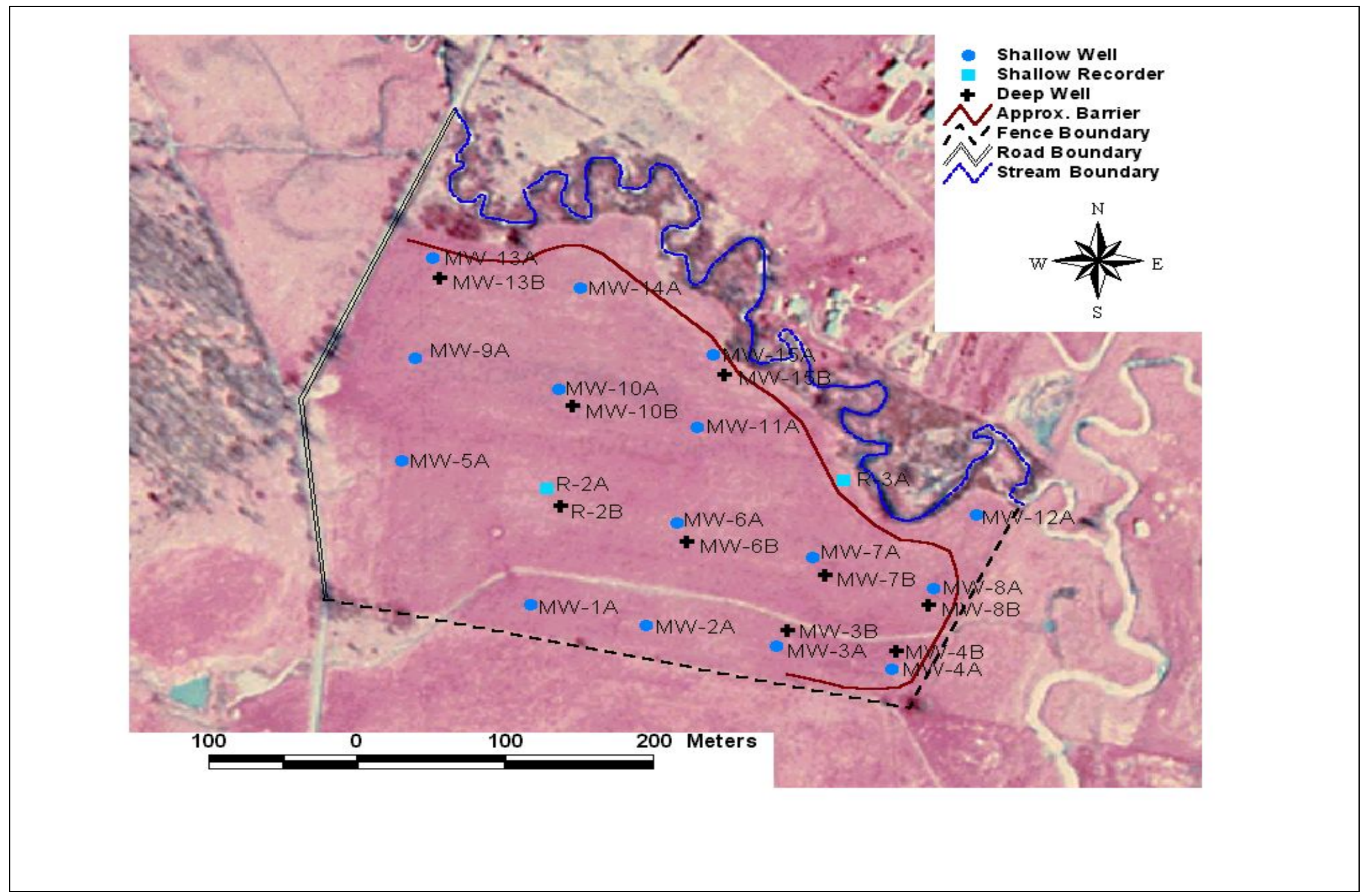

Figure 5-3: Schematic of Barrier Location using one cell (WVGISTC 2000). 


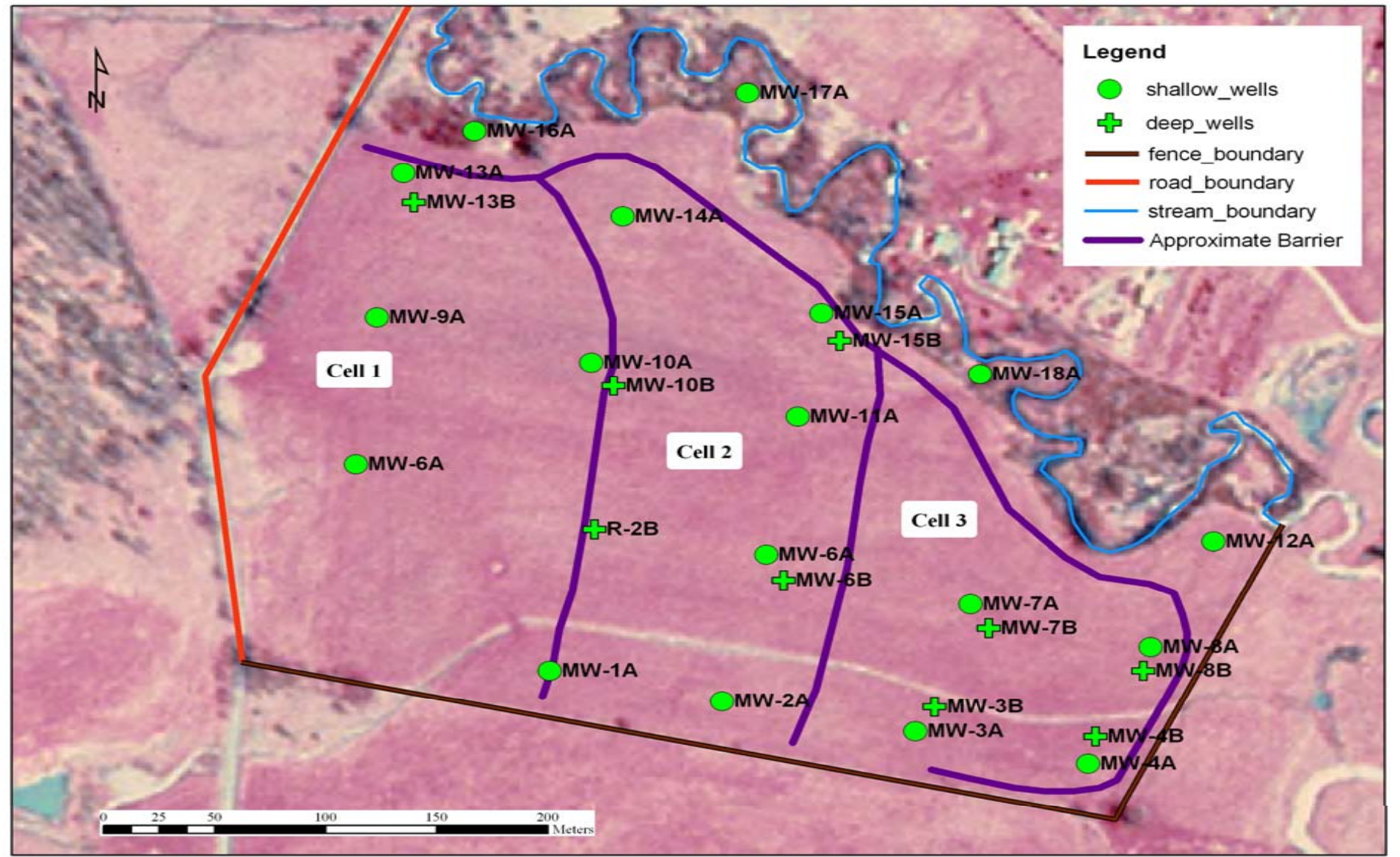

Figure 5-4: Schematic of Barrier Location using three cells (WVGISTC 2000). 




Figure 5-5: Rainfall Data from Recording Well 2 (Messenger 2003). 




Figure 5-6: Rainfall Data from Recording Well 3 (Messenger 2003). 




Figure 5-7: Well Reading Data for the Shallow Monitoring Wells, MW-1 - MW-5. 




Figure 5-8: Well Reading Data for the Shallow Monitoring Wells, MW-6 - MW-10. 




Figure 5-9: Well Reading Data for the Shallow Monitoring Wells, MW-11 - MW-15. 


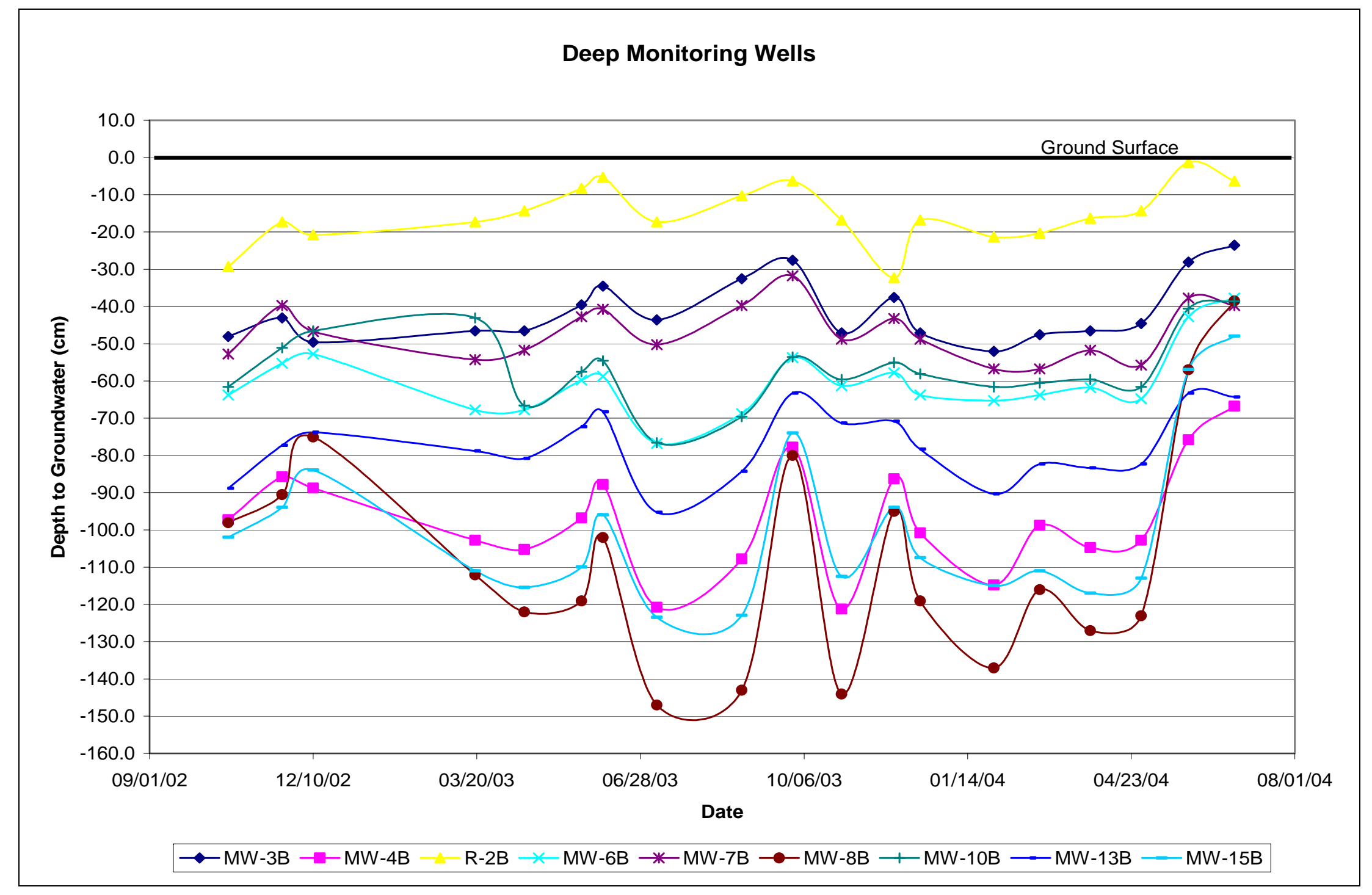

Figure 5-10: Well Reading Data for the Deep Monitoring Wells. 
The installation of the vertical hydraulic barrier can also depend upon it being keyed into an impermeable or nearly impermeable layer. Based upon hydraulic conductivity tests performed in the laboratory (Table 5.1), the soil at the site has a very low permeability. The permeability is low enough to retard water with the installation of a hydraulic barrier. Hydraulic conductivity tests were performed on Shelby tube samples from MW-7B and MW-8B and from reconstructed samples with the same density and water content as that of the site for MW-2B and MW-3B. Laboratory tests were performed on all the monitoring well soil samples that were retrieved from the wetland site. The results concluded in the laboratory testing for the water content, specific gravity, and field density analysis were used in the process of reconstructing samples for the purpose of determining the permeability of the soil at the site. The density value for the reconstructed samples was determined to be $92 \mathrm{lb} / \mathrm{ft}^{3}$. Results from density tests may be found in Table 5.2 and the water content and specific gravity tests results in Table 5.3. Observation of the test pits that were created at the site, show that a layer of soil with clay properties exists approximately ten feet below the surface across the site (Figure 5.11). Results from the classification of the soil at the site verify that the soil is a clayey sand material. Figure 5.12 shows the soil classification of the ground surface layer and Figure 5.13 show the soil classification of the soil at a deep of approximately ten feet. Tables 4.9 and 4.10 list the soil classification of the site using both AASHTO and USCS classification systems. Classification was based upon results from Atterberg limit tests and grain size analysis tests in the laboratory. 
Table 5-1: Hydraulic Conductivity Values at Montrose Site.

\begin{tabular}{|c|c|c|}
\hline Well Location & $\begin{array}{c}\text { Depth } \\
\mathbf{( f t )}\end{array}$ & $\begin{array}{c}\text { Hydraulic Conductivity } \\
\mathbf{( c m} / \mathbf{s})\end{array}$ \\
\hline MW-7B & $9.5^{\prime}-10.5^{\prime}$ & $5.09 \times 10^{-7}$ \\
\hline MW-8B & $7.5^{\prime}-8.8^{\prime}$ & $3.20 \times 10^{-7}$ \\
\hline MW-2B (First Set) & $1.5^{\prime}-4.8^{\prime}$ & $3.71 \times 10^{-8}$ \\
\hline MW-3B (First Set) & $0-1.0^{\prime}$ & $5.89 \times 10^{-7}$ \\
\hline MW-2B (Second Set) & $1.5^{\prime}-4.8^{\prime}$ & $4.11 \times 10^{-8}$ \\
\hline MW-3B (Second Set) & $0-1.0^{\prime}$ & $9.08 \times 10^{-7}$ \\
\hline MW-2B (Third Set) & $1.5^{\prime}-4.8^{\prime}$ & $4.75 \times 10^{-8}$ \\
\hline MW-3B (Third Set) & $0-1.0^{\prime}$ & $3.07 \times 10^{-7}$ \\
\hline
\end{tabular}

Table 5-2: Density Results from laboratory testing.

\begin{tabular}{|c|c|c|}
\hline Test & Type of Density & Value \\
\hline Field Test at Wetland Site & $\gamma_{\text {wet }}$ & $132 \mathrm{lb} / \mathrm{ft}^{3}$ \\
\cline { 2 - 3 }$($ MW-3B) & $\gamma_{\text {dry }}$ & $87 \mathrm{lb} / \mathrm{ft}^{3}$ \\
\hline Laboratory Test on Split \\
spoon sample from MW-3B
\end{tabular}


Table 5-3: Average Water Content and Specific Gravity Values at Montrose Site.

\begin{tabular}{|c|c|c|}
\hline Well Location & Water Content (\%) & Specific Gravity \\
\hline MW-2B & 19.93 & 2.78 \\
\hline MW-3B & 24.78 & 2.69 \\
\hline MW-4B & 15.78 & 2.79 \\
\hline MW-5B & 30.20 & 2.77 \\
\hline MW-6B & 20.46 & 2.73 \\
\hline MW-7B & 20.68 & 2.73 \\
\hline MW-8B & 13.68 & 2.79 \\
\hline MW-9B & 29.96 & 2.79 \\
\hline MW-10B & 17.66 & 2.76 \\
\hline MW-12B & 14.51 & 2.78 \\
\hline MW-13B & 12.08 & 2.75 \\
\hline MW-14B & 21.71 & 2.76 \\
\hline MW-15B & 14.69 & 2.71 \\
\hline $\mathrm{R}-2 \mathrm{~B}$ & 17.21 & 2.82 \\
\hline $\mathrm{R}-3 \mathrm{~B}$ & 29.13 & 2.76 \\
\hline
\end{tabular}






Figure 5-11: Photograph of test pit TP-2, showing strata from ground surface to depth of ten feet. (TS=Top Soil; CL1=Clay Layer 1; SC=Sand-Cobble; CL2=Clay Layer 2) (Fortney 2002).

Based upon visual inspection of the test pits and from the results of the hydraulic conductivity laboratory tests, it was concluded that the layer of soil at a depth of ten feet can provide sufficient support to tie the barrier into and to impede any seepage. Table 5.4 lists the soil classification of the soil at each well at a depth of ten feet. The permeability of the soil has been determined to be suitable for the retention of water and for wetland formation. The soil properties of the existing soil and the installment of a vertical hydraulic barrier should provide suitable conditions for the creation of an engineered wetland habitat. 


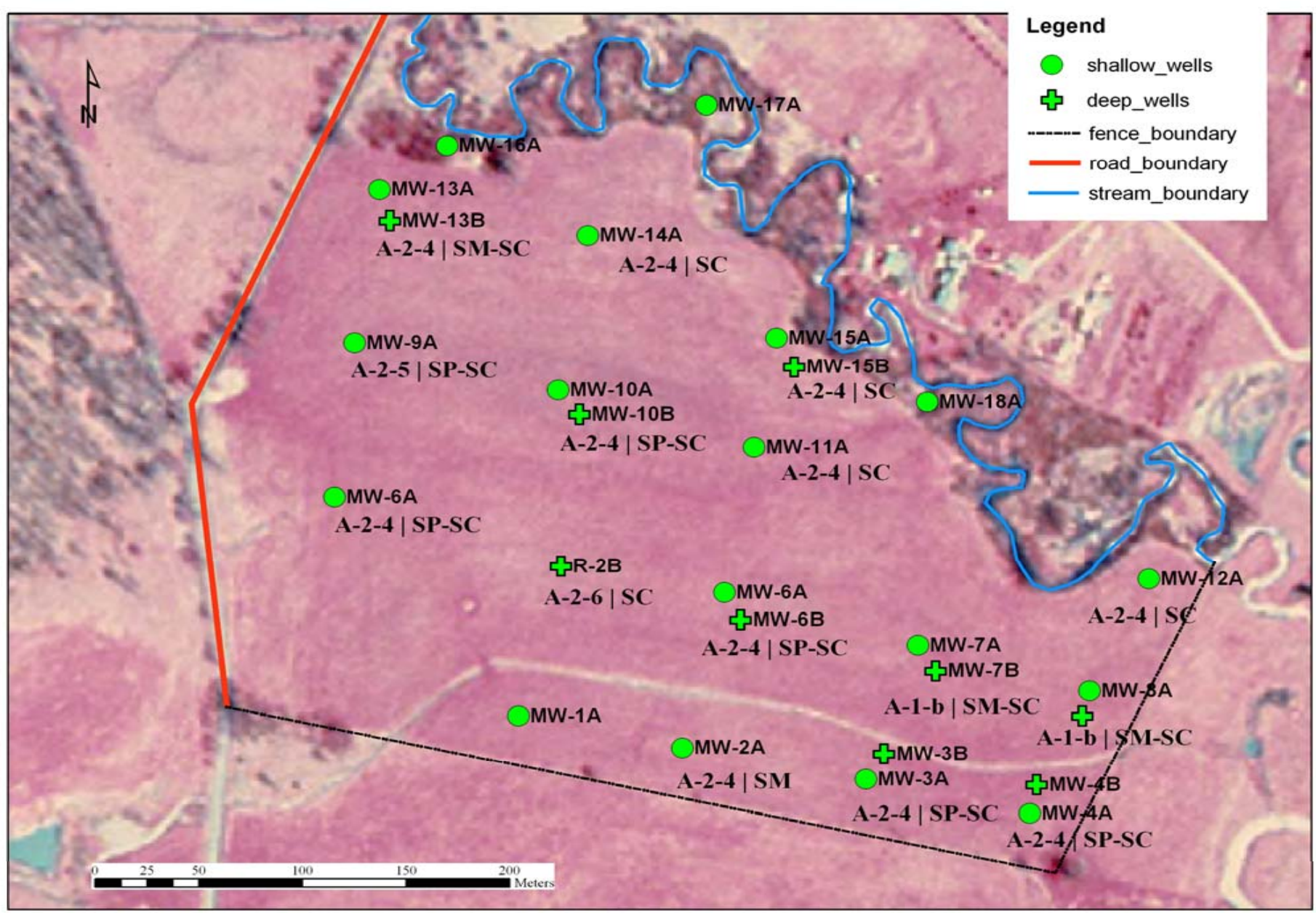

Figure 5-12: Soil Classification of ground surface, using AASHTO and USCS Classification Systems (WVGISTC 2000). 


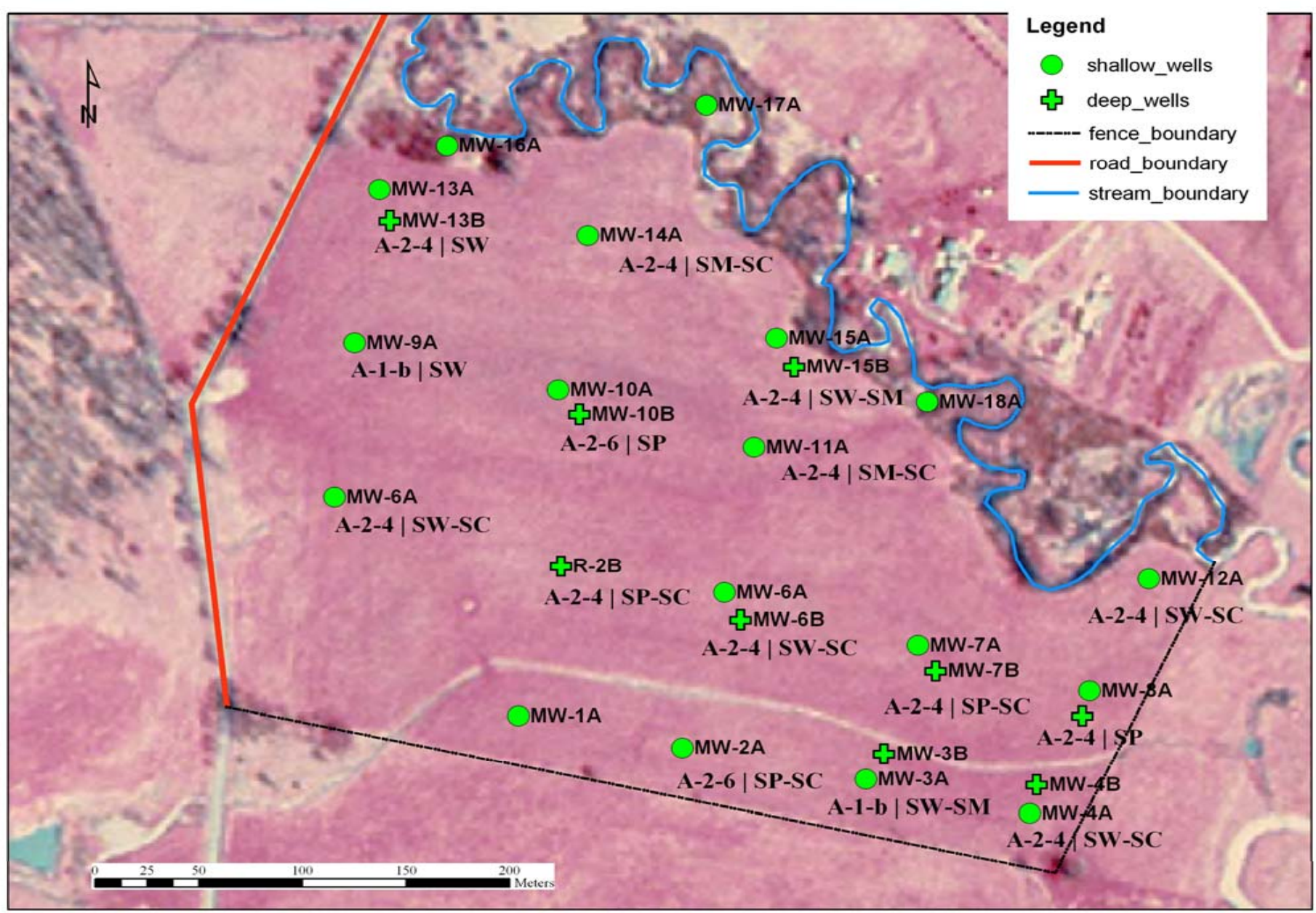

Figure 5-13: Soil Classification of site at approximately ten feet below the ground surface, using AASHTO and USCS Classification Systems (WVGISTC 2000). 
Table 5-4: Classification of Soil at a Depth of Ten Feet.

\begin{tabular}{|c|c|c|}
\cline { 2 - 3 } \multicolumn{1}{c|}{} & $\begin{array}{c}\text { AASHTO } \\
\text { Classification }\end{array}$ & $\begin{array}{c}\text { USCS } \\
\text { Classification }\end{array}$ \\
\hline MW-2B & A-2-6 & SP-SC \\
\hline MW-3B & A-1-b & SW-SM \\
\hline MW-4B & A-2-4 & SW-SC \\
\hline MW-5B & A-2-7 & SP-SC \\
\hline MW-6B & A-2-4 & SW-SC \\
\hline MW-7B & A-2-4 & SP-SC \\
\hline MW-8B & A-2-4 & SP \\
\hline MW-9B & A-1-b & SW \\
\hline MW-10B & A-2-6 & SP \\
\hline MW-12B & A-2-4 & SW-SC \\
\hline MW-13B & A-2-4 & SW \\
\hline MW-14B & A-2-4 & SM-SC \\
\hline MW-15B & A-1-b & SW-SM \\
\hline R-2B & A-2-4 & SP-SC \\
\hline$R-3 B$ & A-2-4 & SM-SC \\
\hline
\end{tabular}

The engineered wetland at the Montrose site may consist of the excavation of a trench to the approximate depth of ten feet deep and two to three feet wide, along a predetermined barrier location. A geosynthetic clay liner (GCL) barrier can then be rolled out through the trench using either the single or double layer method. The trench can then be backfilled and compacted. A berm may be created at the top of the trench, approximately one foot high. The berm can serve two different purposes. The first is to create a dam-like effect to impede any surface water from spilling into the adjacent cell and the second will be to create an area to tie in the GCL barrier at the top. This would also provide sufficient soil cover for the GCL barrier.

Two different types of trenches may be used for the installation of the vertical hydraulic barrier. The first method would involve the side walls of the trench to be sloped (Figure 5.14 and Figure 5.15). This process of a sloping side wall can be used if the stability of the soil is not safe using the vertical cutoff wall. The second is the vertical 
cutoff trench (Figure 5.16 and Figure 5.17). This method would consist of the excavation of a vertical trench, using a backhoe, to a depth of ten feet. The sloped side walls may have no significant advantage over the cutoff wall and would likely require more excavation. The vertical cutoff wall may impede the groundwater more effectively than that of the sloping wall trench. However, the stability of unsupported vertical cuts need to be further investigated.

One option for the hydraulic barrier is to use a GCL barrier, which was discussed earlier in the report (see section 2.2.1.5). Two different approaches may be used in the placement of the GCL barrier: a single layer or a double layer of liner. A single layer would consist in having the material lined on only one side of the trench and anchored at the bottom (Figure 5.14 and Figure 5.16). The double layered approach (Figure 5.15 and Figure 5.17) would consist of lining the trench on both sides and securing both ends into the man made berm created to impede surface water. Implementing either the single or the double layer method with either trench style could provide suitable conditions to create a wetland. The single layer approach would require less GCL material and thus be lower in cost.

Plants associated with wetlands are called macrophytes and are adapted to growing in water-saturated soils (Brix 1994). The vegetation at the site should continue to grow and become adaptive to the wet conditions. In the case where the vegetation should not adapt, a foreign planting scheme may be introduced at the site to create a wetland habitat. The introduction of foreign plants is not recommended in the beginning, due to competition that may occur with native species. The introduction of peat may also be necessary to create favorable wetland conditions. 
Further testing and monitoring of the site should be conducted until the construction of the barrier is complete. Monitoring of both the engineering and environmental functions is necessary to determine the success of the system (Landin et al. 1992). After the completion of the wetland, monitoring should be continued to evaluate the progress of the wetland system. An evaluation of the engineered wetland should occur in three to five years after completion to evaluate the success of the wetland. This would allow sufficient time for wetland development. Additional data should also be collected on the soil properties of backfill material after installation of barrier, to ensure the integrity of the barrier.



Figure 5-14: Sloped Trench Wall with Single Layer Hydraulic Barrier Approach. 


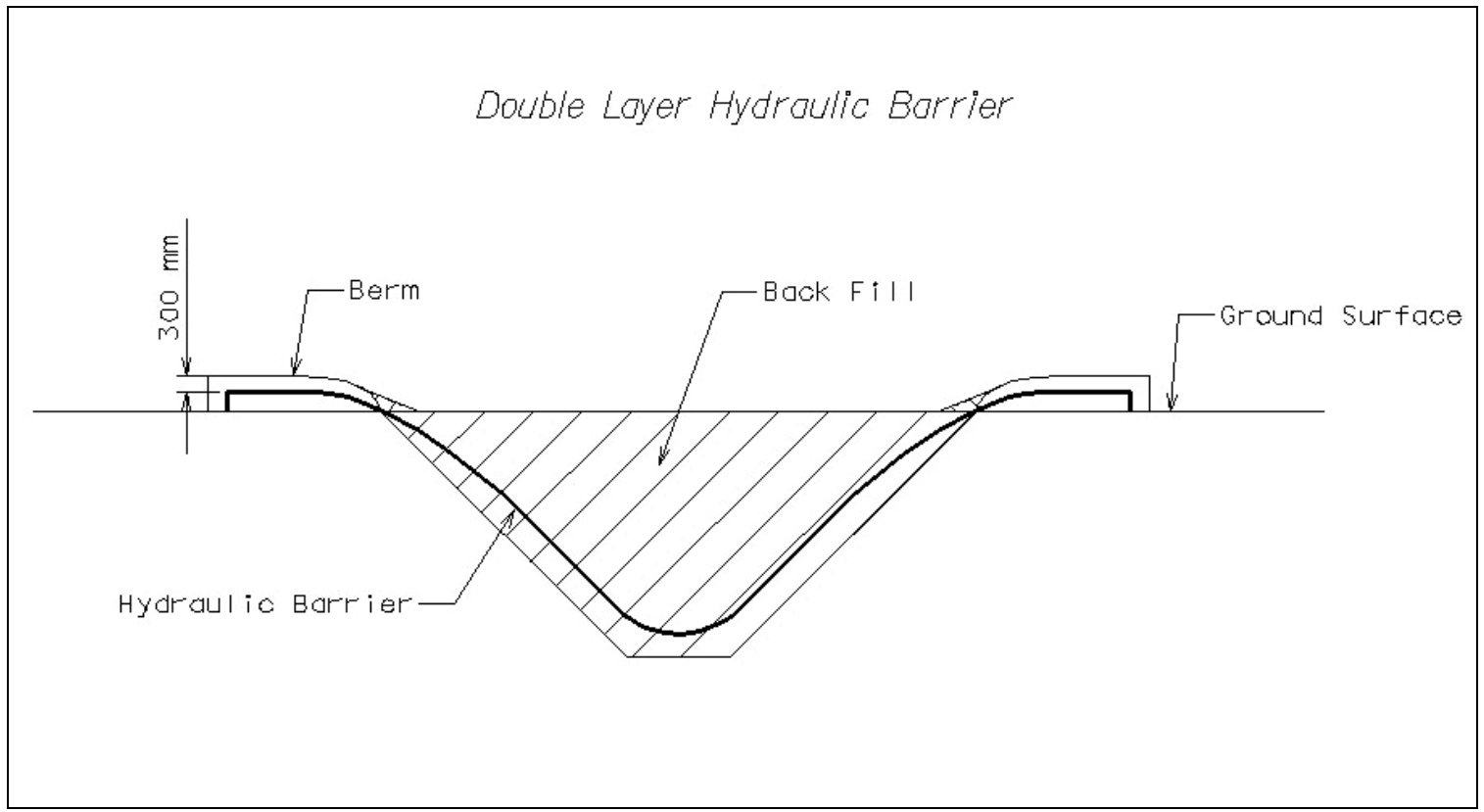

Figure 5-15: Sloped Trench Wall with Double Layer Hydraulic Barrier Approach.

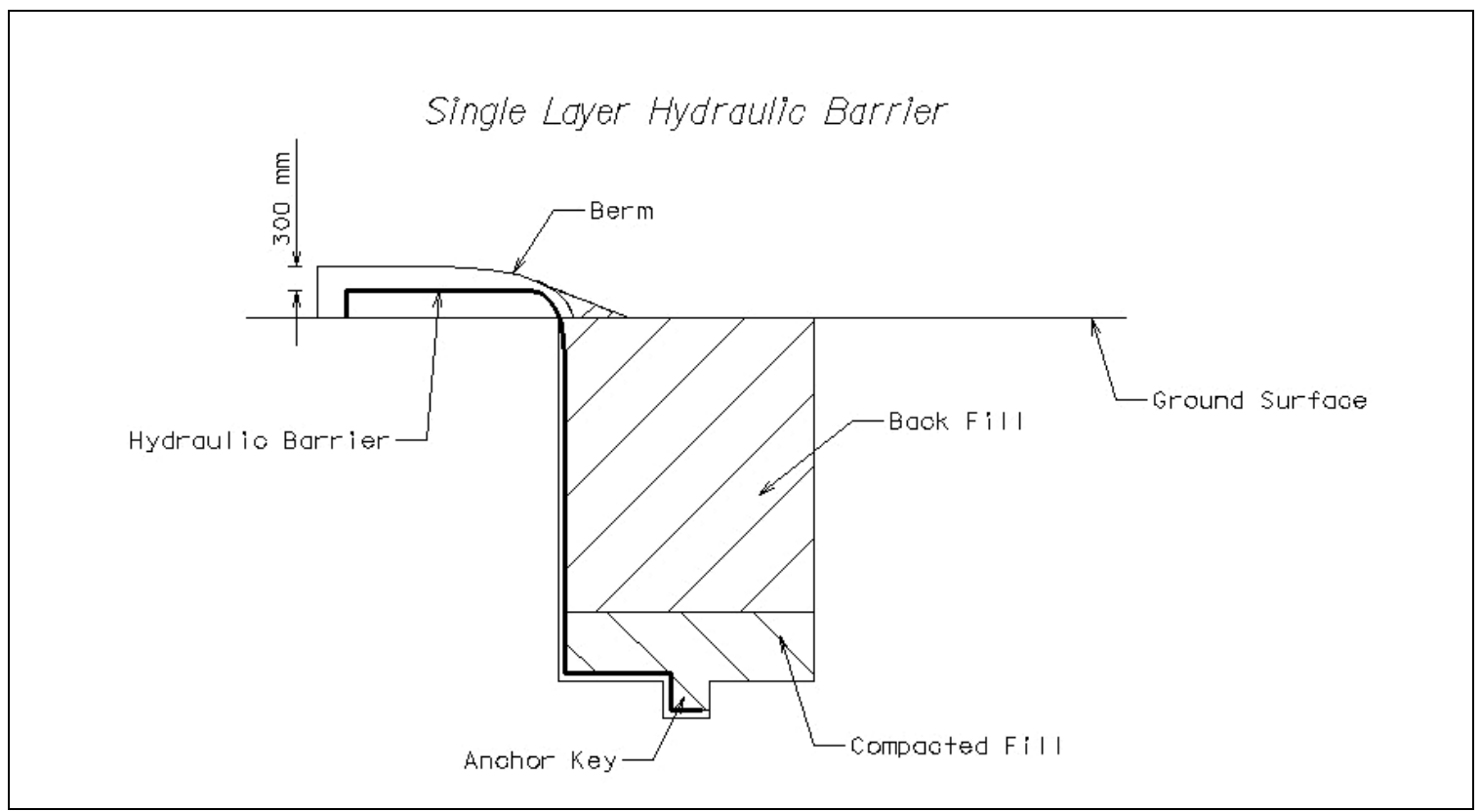

Figure 5-16: Vertical Cutoff Trench Wall with Single Layer Hydraulic Barrier Approach. 


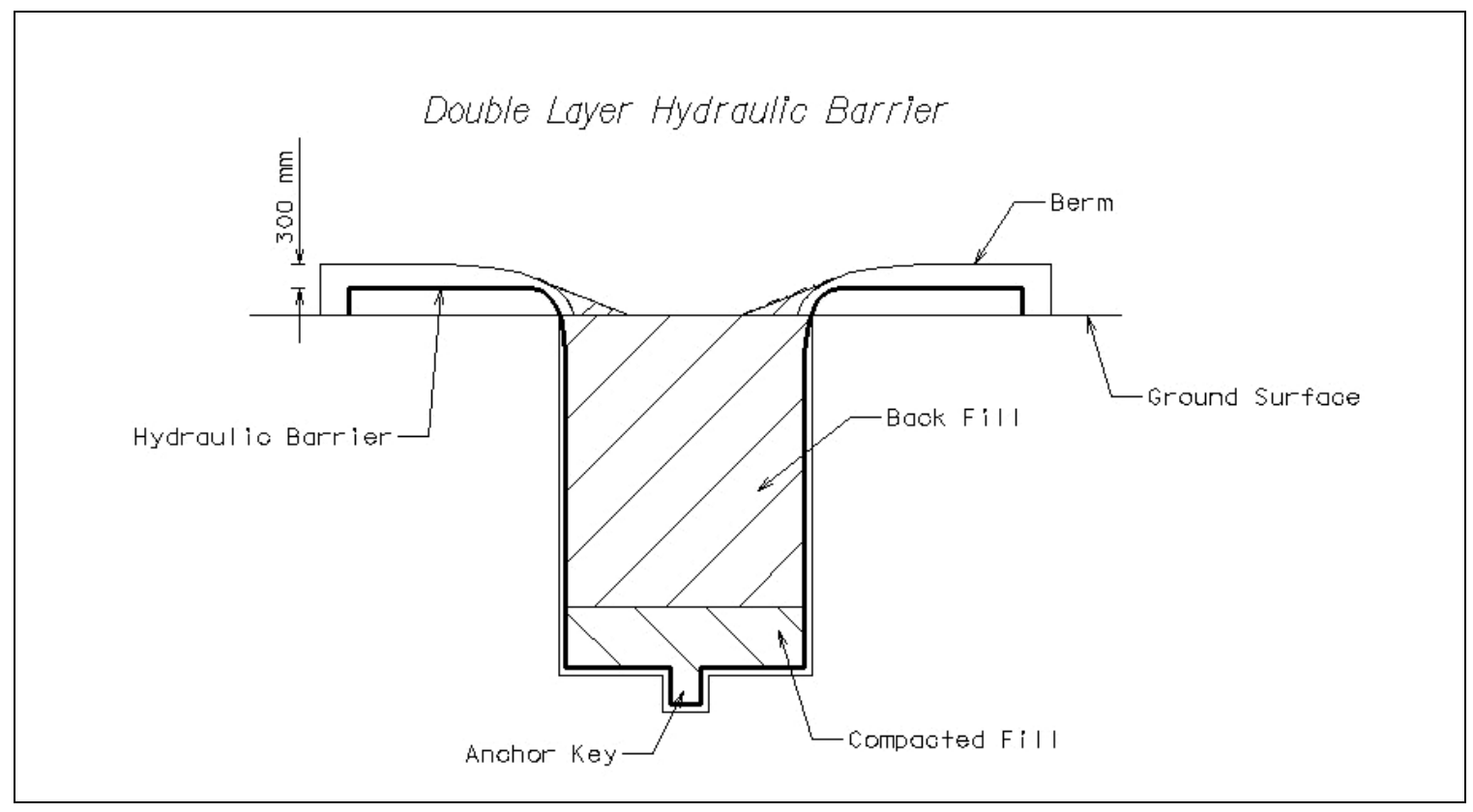

Figure 5-17: Vertical Cutoff Trench Wall with Double Layer Hydraulic Barrier Approach.

\subsection{Conclusions}

Based upon visual inspection of the five test pits and from the results of the soil classification, there exists a layer of clay soil at a depth of ten feet. This clay layer would be suitable to tie in the barrier to the ground. Results from the hydraulic conductivity tests show that the soil at the site is nearly impermeable, but the presence of an external barrier would be needed to impede the groundwater flow. The flow patterns of the groundwater show that a barrier can be placed along the North and East boundaries of the site to produce favorable wetland conditions.

The engineered wetland can consist of a vertical hydraulic barrier. The barrier can be located along the streamline as well as within the body of the site, breaking the site into three cells. A vertical cutoff wall trench with a single layer of liner can be used to construct the barrier. The barrier can be placed down to a depth of ten feet and tie into the existing clay layer. 
The following conclusions can be made:

- The Montrose site is a suitable candidate for wetland creation.

- The existing soil properties at the site are suitable for wetland conditions.

- There exists a layer of clay soil at a depth of ten feet and the barrier can be tied into this clay layer.

- The installation of a vertical hydraulic barrier should impede the subsurface flow and cause it to rise toward the surface. 


\section{REFERENCES}

Brix, H. (1994). "Functions of Macrophytes in Constructed Wetlands." Water Science and Technology, 29, 71-78.

Brown, D.S. (1994). “Constructed Wetlands in the USA.” Water Quality International, 4, 24-28.

Dahl, T.E. (2000). Status and Trends of Wetlands in the Conterminous United States 1986 to 1997. Cartography and Publishing Program, Madison, WI.

Das, B.M. (1998). Principles of Geotechnical Engineering. $4^{\text {th }}$ Edition, PWS Publishing, Boston, MA.

Diehl, J.W. and Behling, R.E. (1982). “Geologic Factors Affecting Formation and Presence of Wetlands in the North Central Section of the Appalachian Plateau Province of West Virginia." Proceedings of the Symposium on Wetlands of the Unglaciated Appalachian Region, Morgantown, WV, 3-10.

Fortney, R.H. (2002). "Proposal to Obtain Soil Boring Cores and to Install Water Observation Wells at the Montrose Mitigation Wetland Site." Unpublished Report.

Frind, E.O., Gillham, R.W., and Pickens, J.F. (1976). "Geotechnical Barrier Testing." Finite Elements in Water Resources. W. Gray and G. Pinder, Eds., Pentech Press, London.

GCL, Geosynthetic Clay Liners, [Online], 2004, Available: http://www.permathene.com/htm/gel.htm, [19 July 2004].

GeoCal, [Online], 2004, Available: http://fbe.uwe.ac.uk/public/geocal/ucp/const_stg1.htm, [22 August 2004].

Geosynthetic Clay Liner, [Online], 2004, Available: http://www.albarrie.com/Geosynthetics/geo-clayliner.html, [21 July 2004].

Hayes, D. F., Olin, T. J., Fischenich, C., and Palermo, M. (2000). Wetlands Engineering Handbook. U.S. Army Corps of Engineers Wetlands Research Program, (ERDC/EL, TR-WRP-RE-21), Washington, DC.

Herlin, B. (2002). "Geosynthetic Clay Liners Offer Many Advantages for Containment Applications." Ennvironmental Science and Engineering. [Online], Available: http://www.esemag.com/0102/clay.html, [14 June 2004]. 
Johnson, A.I., Frobel, R.K., Cavalli, N.J., and Pettersson, C.B. (1985). Hydraulic Barriers in Soil and Rock ASTM STP 874. Philadelphia, PA.

Koerner, R.M. (1990). Designing with Geomembranes. $2^{\text {nd }}$ Edition, Prentice Hall, Englewood Cliffs, NJ.

Koerner, R.M. (2000). "Emerging and Future Developments of Selected Geosynthetic Applications." Journal of Geotechnical and Geoenvironmental Engineering, 126, 293-306.

Koryak, M. (1982). "Wetland Regulation in Appalachia." Proceedings of the Symposium on Wetlands of the Unglaciated Appalachian Region, Morgantown, WV, 233238.

Landin, M.C., Dardeau, E.A., and Miller, J.L. (1992). "Wetland Restoration and Creation Guidelines for Mitigation." Water Resources, 439-444.

Lin, L. and Benson, C.H. (2000). "Effect of Wet-Dry Cycling on Swelling and Hydraulic Conductivity of GCLs." Journal of Geotechnical and Geoenvironmental Engineering, 126, 40-49.

Maltby, E. (1991). "Wetlands and Their Values." Wetlands, M. Finlayson and M. Moser, Eds., 8-26.

Mapson, J. (2004). "Geosynthetic Clay Liners.” ANCID. [Online], Available: http://ancid.org.au/seepage/4_2_18_2_geo.html, [15 July 2004].

Messenger, R.B. (2003). "The Evaluation of a Vertical Hydraulic Barrier as a Mitigation Wetland Design Technique Using a Three-Dimensional Hydrologic Model." Unpublished Report.

Mitsch, W.J. and Gosselink, J.G. (2000). Wetland. $3^{\text {rd }}$ Edition, John Wiley \& Sons, New York, NY.

Mueller, B. (2002). "Technical Guidance and Regulatory Issues for Mitigation Wetlands."

Mundell, J.A. and Bailey, B. (1985). "The Design and Testing of a Compacted Clay Barrier Layer to Limit Percolation through Landfill Covers." Hydraulic Barriers in Soil and Rock, ASTM STP 874. A.I. Johnson, R.K. Frobel, N.J. Cavalli, and C.B. Pettersson, Eds., ASTM, Philadelphia, PA, 246-263.

Page, R.W. and Wilcher, L.S. (1990). "Memorandum of Agreement Between the EPA and the Department of Army Concerning the Determination of Mitigation Under the Clean Water Act Section 404(b)(1) Guidelines." [Online], Available: http://www.usace.army.mil/inet/functions/cw/cecwo/reg/moafe90.htm, [16 May 2004]. 
Phillips, P. and Eberle, M. (2001). "The use of Geosynthetic Clay Liners (GCL's) in containment applications - an Australian perspective." [Online], Available: http://www.bentofix.com/geofabrics/p/geo_env2001.pdf, [14 August 2004].

Pontius, F.W. (1990). "Federal Laws Protecting Wetlands." Journal of American Water Works Association. 82,12-16.

Prakash, A. (1995). “Analysis of Hydraulic Barriers for Ground Water in Stream-Aquifer Systems." Groundwater Management, San Antonio, TX, 337-342.

Price, T. and Probert, D. (1997). "Role of Constructed Wetlands in Environmentally Sustainable Developments." Applied Energy, 57, 129-174.

Shaw, Y.L., Earles, A., and Fitch, G.M. (1998). "Aspects of Functional Analysis of mitigated Wetlands Receiving Highway Runoff." Transportation Research Records, 21-30.

Smardon, R.C. and Karp, J.P. (1993). The Legal Landscape, Van Nostrand Reinhold, NY, New York.

Smith, R.L. and Smith, T.M. (2001). Ecology and Field Biology. $6^{\text {th }}$ Edition, Benjamin Cummings.

Turner, M.H. and Gannon, R. (2003). "Wetlands.” Water Shedss. [Online], Available: http://www.water.ncsu.edu/watershedss, [20 Nov 2003].

WVGISTC, West Virginia GIS Technical Center, [Online], 2000, Available: http://wvgis.wvu.edu/, [11 Jan 2003]. 


\section{VITA}

Christopher R. Ryan was born on August 5, 1980 in Shinnston, West Virginia. He graduated from Lincoln High School in 1998 and enrolled at West Virginia University in Civil and Environmental Engineering. He obtained a Bachelor of Science in Civil Engineering from West Virginia University in 2002. Currently he is a Masters candidate specializing in Geotechnical Engineering at West Virginia University. He is a member of the American Society of Civil Engineers (ASCE). 


\section{APPENDIX}

Appendix A: Montrose Wetland Monitoring Well Data. 
Table A-1: Monitoring Well Elevations (Messenger 2003).

\begin{tabular}{|c|c|c|c|c|}
\hline \multirow{2}{*}{$\begin{array}{c}\text { MONITORING } \\
\text { WELL }\end{array}$} & $\begin{array}{c}\text { GROUND } \\
\text { SURFACE } \\
\text { ELEV }(\mathrm{m})\end{array}$ & \multicolumn{2}{|c|}{ LAYER BOTTOM ELEV $(\mathrm{m})$} \\
\hline MW-2B & 96.79 & 96.33 & 95.32 & 94.04 \\
\hline MW-3B & 94.97 & 94.51 & 92.69 & 92.23 \\
\hline MW-4B & 93.97 & 93.51 & 91.07 & 89.98 \\
\hline MW-5B & 98.98 & 98.52 & 97.70 & 96.54 \\
\hline R-2B & 96.72 & 96.26 & 95.65 & 94.83 \\
\hline MW-6B & 95.78 & 95.33 & 94.72 & 92.12 \\
\hline MW-7B & 94.71 & 94.25 & 92.42 & 91.33 \\
\hline MW-8B & 94.16 & 93.70 & 91.87 & 90.50 \\
\hline MW-9B & 98.10 & 97.65 & 96.73 & 94.84 \\
\hline MW-10B & 96.33 & 95.88 & 94.05 & 92.92 \\
\hline R-3B & 94.71 & 94.25 & 93.49 & 90.68 \\
\hline MW-12B & 94.10 & 93.65 & 92.95 & 90.90 \\
\hline MW-13B & 97.46 & 97.00 & 96.39 & 93.10 \\
\hline MW-14B & 96.45 & 95.99 & 95.56 & 92.33 \\
\hline MW-15B & 95.38 & 94.92 & 94.31 & 91.69 \\
\hline
\end{tabular}

Table A-2: Summary of observation well coring depths below ground surface and construction information (Fortney 2002).

\begin{tabular}{|c|c|c|c|c|c|}
\hline \multirow{2}{*}{$\begin{array}{c}\text { Observation } \\
\text { Well Location }\end{array}$} & \multicolumn{4}{|c|}{ Depths Below Ground Surface (ft) } & Screen \\
& Bottom & $\begin{array}{c}\text { Bottom } \\
\text { Well }\end{array}$ & Top Filter Pack & $\begin{array}{c}\text { Top Bentonite } \\
\text { Seal }\end{array}$ & $\begin{array}{c}\text { Length } \\
\text { (ft) }\end{array}$ \\
\hline MW-3-B & 11.8 & 10.4 & 4.5 & 0.5 & 5.0 \\
\hline MW-4-B & 13.4 & 13.0 & 7.0 & 0.5 & 5.0 \\
\hline MW-6-B & 15.0 & 13.7 & 5.0 & 0.5 & 5.0 \\
\hline MW-7-B & 11.6 & 11.6 & 6.5 & 0.5 & 4.0 \\
\hline MW-8-B & 14.4 & 11.4 & 5.4 & 0.5 & 5.0 \\
\hline MW-10-B & 14.0 & 10.5 & 4.5 & 0.5 & 5.0 \\
\hline MW-13-B & 16.2 & 13.2 & 7.0 & 0.5 & 5.0 \\
\hline MW-15-B & 14.0 & 12.0 & 6.0 & 0.5 & 5.0 \\
\hline R-2-B & 9.5 & 9.2 & 3.5 & 0.5 & 5.0 \\
\hline
\end{tabular}


Table A-3: Summary of Shallow Well Readings, Depth to Groundwater (cm), From 06-05-01 through 11-06-01 (Messenger 2003).

\begin{tabular}{|c|c|c|c|c|c|c|}
\hline \multirow{2}{*}{$\begin{array}{c}\text { Monitoring } \\
\text { Well }\end{array}$} & \multicolumn{7}{|c|}{ Elevation $(\mathrm{cm})$} \\
\cline { 2 - 7 } & $06 / 05 / 01$ & $07 / 09 / 01$ & $08 / 01 / 01$ & $09 / 06 / 01$ & $10 / 11 / 01$ & $11 / 06 / 01$ \\
\hline MW-1 & -47.6 & -39.2 & -41.6 & -50.6 & -56.6 & -60.6 \\
\hline MW-2 & -79.4 & -84.4 & -86.4 & -94.4 & -96.9 & NA* \\
\hline MW-3 & -46.2 & -42.7 & -46.2 & -56.2 & -58.7 & -65.2 \\
\hline MW-4 & -55.3 & -76.8 & -77.3 & -90.3 & -93.8 & -100.3 \\
\hline MW-5 & -73.8 & -60.3 & -59.8 & -69.8 & -74.8 & -81.8 \\
\hline R-2 & -62.5 & -44.7 & -46.2 & -47.0 & -49.6 & NA* $^{*}$ \\
\hline MW-6 & -74.4 & -68.9 & -70.4 & -78.9 & -79.4 & -89.4 \\
\hline MW-7 & -64.8 & -61.9 & -51.8 & -64.8 & -68.3 & -79.8 \\
\hline MW-8 & -66.8 & -66.8 & -66.8 & -66.8 & -67.8 & -67.8 \\
\hline MW-9 & -68.0 & -68.0 & -68.0 & -72.0 & -76.0 & -86.0 \\
\hline MW-10 & -36.9 & -41.9 & -46.9 & -52.9 & -60.9 & -80.9 \\
\hline MW-11 & -53.2 & -49.2 & -34.2 & -53.2 & -52.2 & -59.7 \\
\hline R-3 & -79.2 & -83.1 & -75.4 & -89.7 & -87.4 & -88.9 \\
\hline MW-12 & -53.9 & -53.9 & -53.9 & -54.9 & -53.9 & -55.9 \\
\hline MW-13 & -58.1 & -49.8 & -56.1 & -50.1 & -55.1 & -64.1 \\
\hline MW-14 & -69.1 & -73.6 & -75.1 & -91.1 & -100.1 & NA* \\
\hline MW-15 & -65.3 & -71.8 & -59.3 & -72.3 & -68.3 & -71.3 \\
\hline
\end{tabular}

* NA - No Data Collected

Table A-4: Summary of Shallow Well Readings, Depth to Groundwater (cm), From 12-16--01 through 05-10-02 (Messenger 2003).

\begin{tabular}{|c|c|c|c|c|c|c|}
\hline \multirow{2}{*}{$\begin{array}{c}\text { Monitoring } \\
\text { Device }\end{array}$} & \multicolumn{7}{|c|}{ Elevation (cm) } \\
\cline { 2 - 7 } & $12 / 16 / 01$ & $01 / 21 / 02$ & $02 / 17 / 02$ & $03 / 24 / 02$ & $04 / 25 / 02$ & $05 / 10 / 02$ \\
\hline MW-1 & -61.6 & -60.6 & -62.6 & -48.6 & -56.6 & -48.1 \\
\hline MW-2 & -88.4 & -86.9 & -83.9 & -73.4 & -73.4 & -62.4 \\
\hline MW-3 & -59.7 & -56.2 & -71.2 & -38.2 & -42.7 & -37.2 \\
\hline MW-4 & -101.3 & -103.3 & -84.3 & -103.3 & -79.3 & -59.3 \\
\hline MW-5 & -80.3 & -78.8 & -78.8 & -74.8 & -75.8 & -68.8 \\
\hline R-2 & NA* & NA* & -46.0 & -38.4 & -39.4 & -37.8 \\
\hline MW-6 & -83.4 & -80.4 & -80.4 & -80.4 & -78.4 & -83.4 \\
\hline MW-7 & -76.3 & -66.8 & -66.8 & -48.8 & -56.8 & -58.8 \\
\hline MW-8 & -68.8 & -67.8 & -68.3 & -66.8 & -66.8 & -62.8 \\
\hline MW-9 & -83.0 & -78.0 & -72.5 & -63.0 & -69.0 & -62.0 \\
\hline MW-10 & -68.9 & -66.9 & -49.4 & -39.9 & -38.9 & -36.9 \\
\hline MW-11 & -54.2 & -41.7 & -39.2 & -31.2 & -34.7 & -31.7 \\
\hline R-3 & -71.6 & -78.5 & -78.0 & -64.0 & NA* & NA* \\
\hline MW-12 & -55.4 & -55.9 & -56.4 & -54.9 & NA* & -54.9 \\
\hline MW-13 & -57.1 & -47.1 & -46.1 & -39.1 & -35.6 & -36.6 \\
\hline MW-14 & -92.1 & -81.1 & -81.1 & -74.1 & -75.1 & -70.1 \\
\hline MW-15 & -67.3 & -59.3 & -57.3 & -42.3 & -42.3 & -40.3 \\
\hline
\end{tabular}

* NA - No Data Collected 
Table A-5: Summary of Shallow Well Readings, Depth to Groundwater (cm), From 06-18-02 through 07-08-03.

\begin{tabular}{|c|c|c|c|c|c|c|}
\hline \multirow{2}{*}{$\begin{array}{c}\text { Monitoring } \\
\text { Well }\end{array}$} & \multicolumn{7}{|c|}{ Elevation $(\mathrm{cm})$} \\
\cline { 2 - 7 } & $06 / 18 / 02$ & $03 / 19 / 03$ & $04 / 18 / 03$ & $05 / 23 / 03$ & $06 / 05 / 03$ & $07 / 08 / 03$ \\
\hline MW-1 & -63.6 & -64.6 & -69.6 & -64.6 & -59.6 & -50.6 \\
\hline MW-2 & -88.4 & -98.4 & -92.4 & -91.9 & -88.4 & -85.9 \\
\hline MW-3 & -56.2 & -98.2 & -58.7 & -61.2 & -98.2 & -92.2 \\
\hline MW-4 & -89.3 & -104.3 & -87.3 & -87.8 & -85.3 & NA* $^{*}$ \\
\hline MW-5 & -79.8 & -102.8 & -81.3 & -100.8 & -80.8 & NA* $^{*}$ \\
\hline R-2 & NA* & NA* & NA* & NA* & NA* $^{*}$ & NA* $^{*}$ \\
\hline MW-6 & -81.4 & -96.4 & -92.4 & -80.4 & -81.4 & -81.4 \\
\hline MW-7 & -64.8 & -63.4 & -64.3 & -63.8 & -64.8 & NA* \\
\hline MW-8 & NA* & -68.3 & -66.8 & -67.8 & -68.8 & -67.8 \\
\hline MW-9 & -81.0 & NA* & NA* & -76.8 & -69.8 & -63.8 \\
\hline MW-10 & -53.4 & -74.4 & -54.4 & -43.9 & -39.4 & -69.9 \\
\hline MW-11 & -59.2 & -64.2 & -69.2 & -64.2 & -48.2 & NA* \\
\hline R-3 & NA* & NA* & NA* & NA* & NA* & NA* \\
\hline MW-12 & -54.4 & -55.9 & -55.4 & -55.9 & -55.9 & -54.9 \\
\hline MW-13 & -48.1 & NA $^{*}$ & -65.2 & -64.2 & -60.2 & -60.2 \\
\hline MW-14 & -93.1 & -81.1 & -85.1 & -78.1 & -75.1 & -82.1 \\
\hline MW-15 & -62.3 & -64.3 & -69.3 & -70.3 & -62.3 & -57.3 \\
\hline MW-16 & NA* $^{*}$ & NA* $^{*}$ & -104.3 & -102.3 & -97.3 & -99.3 \\
\hline MW-17 & NA* & -47.7 & -56.2 & -55.2 & -47.2 & -63.2 \\
\hline MW-18 & NA* $^{*}$ & -19.4 & -33.4 & -26.4 & -11.4 & -34.4 \\
\hline
\end{tabular}

* NA - No Data Collected

Table A-6: Summary of Shallow Well Readings, Depth to Groundwater (cm), From 08-29-03 through 01-30-04.

\begin{tabular}{|c|c|c|c|c|c|c|}
\hline \multirow{2}{*}{$\begin{array}{c}\text { Monitoring } \\
\text { Device }\end{array}$} & \multicolumn{7}{|c|}{ Elevation $(\mathrm{cm})$} \\
\cline { 2 - 7 } & $08 / 29 / 03$ & $09 / 29 / 03$ & $10 / 29 / 03$ & $11 / 30 / 03$ & $12 / 16 / 03$ & $01 / 30 / 04$ \\
\hline MW-1 & -63.3 & -75.6 & -48.6 & -52.6 & -94.6 & -63.6 \\
\hline MW-2 & -92.9 & -86.4 & -88.4 & -84.4 & -103.4 & -105.4 \\
\hline MW-3 & -68.2 & -32.2 & -106.2 & -44.7 & -105.2 & -100.2 \\
\hline MW-4 & -52.9 & -33.4 & -86.9 & -54.9 & -72.9 & -85.9 \\
\hline MW-5 & -100.1 & -55.1 & -77.6 & -62.6 & -99.1 & -94.1 \\
\hline R-2 & NA* & NA* & NA $^{*}$ & NA $^{*}$ & NA* $^{*}$ & NA* \\
\hline MW-6 & -86.4 & -85.4 & -79.4 & -80.4 & -90.4 & -90.4 \\
\hline MW-7 & -54.0 & -56.0 & -74.0 & -52.5 & -74.0 & -94.0 \\
\hline MW-8 & -66.8 & -62.8 & -69.3 & -66.8 & -69.3 & -70.8 \\
\hline MW-9 & -70.8 & -61.8 & -65.8 & NA* & NA* & NA* \\
\hline MW-10 & -45.9 & -28.9 & -26.9 & -31.4 & -60.9 & -95.9 \\
\hline MW-11 & NA* & -44.7 & -72.7 & -42.7 & -67.7 & -84.7 \\
\hline R-3 & NA* & NA* & NA* & NA* & NA* & NA* \\
\hline MW-12 & -56.9 & -55.9 & -56.9 & -54.9 & -57.9 & -56.9 \\
\hline MW-13 & -63.2 & -60.2 & -55.2 & -63.2 & -62.2 & -63.2 \\
\hline MW-14 & -93.1 & -73.1 & -74.6 & -76.1 & -106.1 & -112.6 \\
\hline MW-15 & -70.3 & -45.3 & -67.3 & -55.3 & -66.3 & -75.3 \\
\hline MW-16 & -97.3 & -99.3 & -100.3 & -102.3 & -100.3 & -92.3 \\
\hline MW-17 & -64.7 & -19.2 & -37.2 & -16.7 & -48.2 & -57.2 \\
\hline MW-18 & -39.4 & -4.4 & -29.4 & -9.4 & -85.9 & -34.4 \\
\hline
\end{tabular}

* NA - No Data Collected 
Table A-7: Summary of Shallow Well Readings, Depth to Groundwater (cm), From 02-27-04 through 06-25-04.

\begin{tabular}{|c|c|c|c|c|c|}
\hline \multirow{2}{*}{$\begin{array}{l}\text { Monitoring } \\
\text { Device }\end{array}$} & \multicolumn{5}{|c|}{ Elevation $(\mathrm{cm})$} \\
\hline & $02 / 27 / 04$ & $03 / 29 / 04$ & $04 / 29 / 04$ & $05 / 28 / 04$ & $06 / 25 / 04$ \\
\hline MW-1 & -81.6 & -85.6 & -61.6 & -20.6 & -55.6 \\
\hline MW-2 & -90.4 & -95.4 & -91.4 & -36.4 & -81.4 \\
\hline MW-3 & -93.2 & -86.2 & -96.2 & -100.2 & -59.2 \\
\hline MW-4 & -74.4 & -75.9 & -74.9 & -27.9 & -62.9 \\
\hline MW-5 & -98.1 & -97.1 & -92.1 & -29.1 & -67.1 \\
\hline $\mathrm{R}-2$ & NA* & NA* & NA* & NA* & NA* \\
\hline MW-6 & -90.4 & -90.4 & -93.4 & -45.4 & -70.4 \\
\hline MW-7 & -69.0 & -59.0 & -57.0 & -45.0 & -51.0 \\
\hline MW-8 & -68.8 & -68.8 & -68.8 & -50.8 & -62.8 \\
\hline MW-9 & NA* & NA* & NA* & NA* & NA* \\
\hline MW-10 & -38.9 & -41.9 & -38.9 & -33.9 & -29.9 \\
\hline MW-11 & -68.2 & -63.7 & -65.2 & -43.7 & -50.2 \\
\hline $\mathrm{R}-3$ & NA* & NA* & NA* & NA* & NA* \\
\hline MW-12 & $\begin{array}{l}-56.9 \\
\end{array}$ & $\begin{array}{l}-55.9 \\
\end{array}$ & $\begin{array}{l}-54.9 \\
\end{array}$ & $\begin{array}{l}-53.9 \\
\end{array}$ & $\begin{array}{l}-54.9 \\
\end{array}$ \\
\hline MW-13 & -55.2 & -78.2 & -63.2 & -52.2 & -55.2 \\
\hline MW-14 & -108.6 & -108.1 & -87.1 & -42.1 & -84.1 \\
\hline MW-15 & -66.3 & -75.3 & -71.3 & -31.3 & -65.3 \\
\hline MW-16 & -94.3 & $\begin{array}{l}-79.3 \\
\end{array}$ & -80.3 & -70.3 & $\begin{array}{l}-71.3 \\
\end{array}$ \\
\hline MW-17 & -96.2 & -58.2 & NA* & -26.2 & -45.2 \\
\hline MW-18 & -38.4 & -74.4 & -77.4 & NA* & -62.4 \\
\hline
\end{tabular}

* NA - No Data Collected

Table A-8: Summary of Shallow Well Readings, Depth to Potentiometric Surface (m), From 06-0501 through 11-06-01 (Messenger 2003).

\begin{tabular}{|c|c|c|c|c|c|c|}
\hline \multirow{2}{*}{$\begin{array}{c}\text { Monitoring } \\
\text { Device }\end{array}$} & \multicolumn{7}{|c|}{ Elevation $(\mathrm{m})$} \\
\cline { 2 - 7 } & $06 / 05 / 01$ & $07 / 09 / 01$ & $08 / 01 / 01$ & $09 / 06 / 01$ & $10 / 11 / 01$ & $11 / 06 / 01$ \\
\hline MW-1 & 97.32 & 97.41 & 97.38 & 97.29 & 97.23 & 97.19 \\
\hline MW-2 & 95.99 & 95.94 & 95.92 & 95.84 & 95.82 & NA* \\
\hline MW-3 & 94.44 & 94.47 & 94.44 & 94.34 & 94.31 & 94.25 \\
\hline MW-4 & 93.41 & 93.19 & 93.19 & 93.06 & 93.02 & 92.96 \\
\hline MW-5 & 98.24 & 98.37 & 98.38 & 98.28 & 98.23 & 98.16 \\
\hline R-2 & 96.04 & 96.22 & 96.20 & 96.19 & 96.17 & NA* \\
\hline MW-6 & 95.08 & 95.13 & 95.12 & 95.03 & 95.03 & 94.93 \\
\hline MW-7 & 94.10 & 94.13 & 94.23 & 94.10 & 94.07 & 93.95 \\
\hline MW-8 & 93.43 & 93.43 & 93.43 & 93.43 & 93.42 & 93.42 \\
\hline MW-9 & 97.42 & 97.42 & 97.42 & 97.38 & 97.34 & 97.24 \\
\hline MW-10 & 96.03 & 95.98 & 95.93 & 95.87 & 95.79 & 95.59 \\
\hline MW-11 & 94.73 & 94.77 & 94.92 & 94.73 & 94.74 & 94.67 \\
\hline R-3 & 93.91 & 93.88 & 93.95 & 93.81 & 93.83 & 93.82 \\
\hline MW-12 & 93.57 & 93.57 & 93.57 & 93.56 & 93.57 & 93.55 \\
\hline MW-13 & 96.91 & 96.99 & 96.93 & 96.99 & 96.94 & 96.85 \\
\hline MW-14 & 95.76 & 95.71 & 95.70 & 95.54 & 95.45 & NA* \\
\hline MW-15 & 94.63 & 94.56 & 94.69 & 94.56 & 94.60 & 94.57 \\
\hline
\end{tabular}

* NA - No Data Collected 
Table A-9: Summary of Shallow Well Readings, Depth to Potentiometric Surface (m), From 12-1601 through 5-10-02 (Messenger 2003).

\begin{tabular}{|c|c|c|c|c|c|c|}
\hline \multirow{2}{*}{$\begin{array}{c}\text { Monitoring } \\
\text { Device }\end{array}$} & \multicolumn{7}{|c|}{ Elevation $(\mathrm{m})$} \\
\cline { 2 - 7 } & $12 / 16 / 01$ & $01 / 21 / 02$ & $02 / 17 / 02$ & $03 / 24 / 02$ & $04 / 25 / 02$ & $05 / 10 / 02$ \\
\hline MW-1 & 97.18 & 97.19 & 97.17 & 97.31 & 97.23 & 97.32 \\
\hline MW-2 & 95.90 & 95.92 & 95.95 & 96.05 & 96.05 & 96.16 \\
\hline MW-3 & 94.30 & 94.34 & 94.19 & 94.52 & 94.47 & 94.53 \\
\hline MW-4 & 92.95 & 92.93 & 93.12 & 92.93 & 93.17 & 93.37 \\
\hline MW-5 & 98.17 & 98.19 & 98.19 & 98.23 & 98.22 & 98.29 \\
\hline R-2 & NA* & NA* & 96.21 & 96.28 & 96.27 & 96.29 \\
\hline MW-6 & 94.99 & 95.02 & 95.02 & 95.02 & 95.04 & 94.99 \\
\hline MW-7 & 93.99 & 94.08 & 94.08 & 94.26 & 94.18 & 94.16 \\
\hline MW-8 & 93.41 & 93.42 & 93.41 & 93.43 & 93.43 & 93.47 \\
\hline MW-9 & 97.27 & 97.32 & 97.38 & 97.47 & 97.41 & 97.48 \\
\hline MW-10 & 95.71 & 95.73 & 95.91 & 96.00 & 96.01 & 96.03 \\
\hline MW-11 & 94.72 & 94.85 & 94.87 & 94.95 & 94.92 & 94.95 \\
\hline R-3 & 93.99 & 93.92 & 93.93 & 94.07 & NA* & NA* \\
\hline MW-12 & 93.55 & 93.55 & 93.54 & 93.56 & NA* & 93.56 \\
\hline MW-13 & 96.92 & 97.02 & 97.03 & 97.10 & 97.13 & 97.12 \\
\hline MW-14 & 95.53 & 95.64 & 95.64 & 95.71 & 95.70 & 95.75 \\
\hline MW-15 & 94.61 & 94.69 & 94.71 & 94.86 & 94.86 & 94.88 \\
\hline
\end{tabular}

* NA - No Data Collected

Table A-10: Summary of Shallow Well Readings, Depth to Potentiometric Surface (m), From 06-1802 through 07-08-03.

\begin{tabular}{|c|c|c|c|c|c|c|}
\hline \multirow{2}{*}{$\begin{array}{c}\text { Monitoring } \\
\text { Well }\end{array}$} & \multicolumn{7}{|c|}{ Elevation (m) } \\
\cline { 2 - 7 } & $06 / 18 / 02$ & $03 / 19 / 03$ & $04 / 18 / 03$ & $05 / 23 / 03$ & $06 / 05 / 03$ & $07 / 08 / 03$ \\
\hline MW-1 & 97.16 & 97.15 & 97.10 & 97.15 & 97.20 & 97.29 \\
\hline MW-2 & 95.90 & 95.80 & 95.86 & 95.87 & 95.90 & 95.93 \\
\hline MW-3 & 94.34 & 93.92 & 94.31 & 94.29 & 93.92 & 93.98 \\
\hline MW-4 & 93.07 & 92.92 & 93.09 & 93.08 & 93.11 & NA* $^{*}$ \\
\hline MW-5 & 98.18 & 97.95 & 98.16 & 97.97 & 98.17 & NA* $^{*}$ \\
\hline R-2 & NA* & NA* & NA* & NA* $^{*}$ & NA* $^{*}$ & NA* $^{*}$ \\
\hline MW-6 & 95.01 & 94.86 & 94.90 & 95.02 & 95.01 & 95.01 \\
\hline MW-7 & 94.10 & 94.11 & 94.11 & 94.11 & 94.10 & NA* $^{*}$ \\
\hline MW-8 & NA* & 93.41 & 93.42 & 93.41 & 93.40 & 93.41 \\
\hline MW-9 & 97.29 & NA* & NA* & 97.22 & 97.29 & 97.35 \\
\hline MW-10 & 95.87 & 95.66 & 95.86 & 95.96 & 96.00 & 95.70 \\
\hline MW-11 & 94.67 & 94.62 & 94.57 & 94.62 & 94.78 & NA* \\
\hline R-3 & NA* & NA* & NA* & NA* & NA* & NA* \\
\hline MW-12 & 93.56 & 93.55 & 93.55 & 93.54 & 93.54 & 93.55 \\
\hline MW-13 & 97.00 & NA* & 96.81 & 96.82 & 96.86 & 96.86 \\
\hline MW-14 & 95.52 & 95.64 & 95.60 & 95.67 & 95.70 & 95.63 \\
\hline MW-15 & 94.66 & 94.64 & 94.59 & 94.58 & 94.66 & 94.71 \\
\hline MW-16 & NA* & NA* $^{*}$ & 96.36 & 96.38 & 96.43 & 96.41 \\
\hline MW-17 & NA* & 95.33 & 95.20 & 95.21 & 95.39 & 95.30 \\
\hline MW-18 & NA* & 93.64 & 93.50 & 93.57 & 93.72 & 93.49 \\
\hline
\end{tabular}

* NA - No Data Collected 
Table A-11: Summary of Shallow Well Readings, Depth to Potentiometric Surface (m), From 08-2903 through 01-30-04.

\begin{tabular}{|c|c|c|c|c|c|c|}
\hline \multirow{2}{*}{$\begin{array}{c}\text { Monitoring } \\
\text { Device }\end{array}$} & \multicolumn{7}{|c|}{ Elevation $(\mathrm{m})$} \\
\cline { 2 - 7 } & $08 / 29 / 03$ & $09 / 29 / 03$ & $10 / 29 / 03$ & $11 / 30 / 03$ & $12 / 16 / 03$ & $01 / 30 / 04$ \\
\hline MW-1 & 97.16 & 97.04 & 97.31 & 97.27 & 96.85 & 97.16 \\
\hline MW-2 & 95.86 & 95.92 & 95.90 & 95.94 & 95.75 & 95.75 \\
\hline MW-3 & 94.22 & 94.58 & 93.84 & 94.46 & 93.85 & 93.90 \\
\hline MW-4 & 93.27 & 93.46 & 92.93 & 93.25 & 93.07 & 92.94 \\
\hline MW-5 & 97.70 & 98.15 & 97.92 & 98.07 & 97.71 & 97.76 \\
\hline R-2 & NA* & NA* & NA* $^{*}$ & NA* $^{*}$ & NA* $^{*}$ & NA* $^{*}$ \\
\hline MW-6 & 94.96 & 94.97 & 94.87 & 95.03 & 95.02 & 94.92 \\
\hline MW-7 & 94.09 & 94.07 & 93.89 & 94.10 & 93.89 & 93.69 \\
\hline MW-8 & 93.42 & 93.46 & 93.40 & 93.42 & 93.46 & 93.38 \\
\hline MW-9 & 97.28 & 97.37 & 97.33 & NA* $^{*}$ & NA* & NA* \\
\hline MW-10 & 95.94 & 96.11 & 96.13 & 96.09 & 95.79 & 95.44 \\
\hline MW-11 & NA* & 94.83 & 94.56 & 94.85 & 94.60 & 94.35 \\
\hline R-3 & NA* & NA* & NA* & NA* & NA* & NA* \\
\hline MW-12 & 93.53 & 93.54 & 93.53 & 93.55 & 93.52 & 93.53 \\
\hline MW-13 & 96.83 & 96.86 & 96.91 & 96.83 & 96.84 & 96.83 \\
\hline MW-14 & 95.52 & 95.72 & 95.70 & 95.69 & 95.39 & 95.32 \\
\hline MW-15 & 94.58 & 94.83 & 94.61 & 94.23 & 94.62 & 94.53 \\
\hline MW-16 & 96.43 & 96.41 & 96.40 & 96.38 & 96.40 & 96.48 \\
\hline MW-17 & 95.12 & 95.57 & 95.39 & 95.59 & 95.28 & 95.19 \\
\hline MW-18 & 93.44 & 93.79 & 93.54 & 93.74 & 92.77 & 93.48 \\
\hline
\end{tabular}

* NA - No Data Collected

Table A-12: Summary of Shallow Well Readings, Depth to Potentiometric Surface (m), From 02-2704 through 06-25-04.

\begin{tabular}{|c|c|c|c|c|c|}
\hline \multirow{2}{*}{$\begin{array}{c}\text { Monitoring } \\
\text { Device }\end{array}$} & \multicolumn{5}{|c|}{ Elevation $(\mathrm{m})$} \\
\cline { 2 - 6 } & $02 / 27 / 04$ & $03 / 29 / 04$ & $04 / 29 / 04$ & $05 / 28 / 04$ & $06 / 25 / 04$ \\
\hline MW-1 & 96.98 & 96.94 & 97.18 & 97.59 & 97.24 \\
\hline MW-2 & 95.88 & 95.83 & 95.87 & 96.42 & 95.97 \\
\hline MW-3 & 93.97 & 94.04 & 93.94 & 93.90 & 94.31 \\
\hline MW-4 & 93.05 & 93.04 & 93.03 & 93.52 & 93.17 \\
\hline MW-5 & 97.72 & 97.73 & 97.78 & 98.41 & 98.03 \\
\hline R-2 & NA* & NA* & NA* & NA* $^{*}$ & NA* \\
\hline MW-6 & 94.92 & 94.92 & 94.89 & 95.31 & 95.12 \\
\hline MW-7 & 93.94 & 94.04 & 94.06 & 94.18 & 94.18 \\
\hline MW-8 & 93.40 & 93.40 & 93.40 & 93.56 & 93.46 \\
\hline MW-9 & NA* & NA* & NA* & NA* & NA* \\
\hline MW-10 & 96.01 & 95.98 & 96.01 & 96.06 & 96.10 \\
\hline MW-11 & 94.60 & 94.64 & 94.61 & 94.85 & 94.78 \\
\hline R-3 & NA* & NA* & NA* & NA* & NA* \\
\hline MW-12 & 93.53 & 93.54 & 93.55 & 93.51 & 93.55 \\
\hline MW-13 & 96.91 & 96.68 & 96.83 & 96.94 & 96.97 \\
\hline MW-14 & 95.38 & 95.37 & 95.58 & 95.83 & 95.61 \\
\hline MW-15 & 94.62 & 94.53 & 94.57 & 94.91 & 94.63 \\
\hline MW-16 & 96.46 & 96.61 & 96.60 & 96.70 & 96.69 \\
\hline MW-17 & 94.80 & 95.18 & NA* & 95.50 & 95.31 \\
\hline MW-18 & 93.45 & 93.09 & 93.06 & NA* $^{*}$ & 93.21 \\
\hline
\end{tabular}

* NA - No Data Collected 
Table A-13: Summary of Deep Well Readings, Depth to Groundwater (cm), From10-19-02 through 05-23-03.

\begin{tabular}{|c|c|c|c|c|c|c|}
\hline \multirow{2}{*}{$\begin{array}{c}\text { Monitoring } \\
\text { Well }\end{array}$} & \multicolumn{7}{|c|}{ Elevation $(\mathrm{cm})$} \\
\cline { 2 - 7 } & $10 / 19 / 02$ & $11 / 21 / 02$ & $12 / 10 / 02$ & $03 / 19 / 03$ & $04 / 18 / 03$ & $05 / 23 / 03$ \\
\hline MW-3B & -48.1 & -43.1 & -49.6 & -46.6 & -46.6 & -37.6 \\
\hline MW-3B & -97.3 & -85.8 & -88.8 & -102.8 & -105.5 & -96.8 \\
\hline MW-3B & -29.3 & -17.3 & -20.8 & -17.3 & -14.3 & -8.3 \\
\hline MW-3B & -63.8 & -55.3 & -52.8 & -67.8 & -67.8 & -59.8 \\
\hline MW-3B & -52.8 & -39.8 & -46.8 & -54.3 & -51.8 & -42.8 \\
\hline MW-3B & -98.0 & -90.5 & -75.0 & -112.0 & -122.0 & -119.0 \\
\hline MW-3B & -61.6 & -51.1 & -46.6 & -43.1 & -66.6 & -57.6 \\
\hline MW-3B & -88.8 & -77.3 & -73.8 & -78.8 & -80.8 & -72.3 \\
\hline MW-3B & -102.0 & -94.0 & -84.0 & -111.0 & -115.5 & -110.0 \\
\hline
\end{tabular}

Table A-14: Summary of Deep Well Readings, Depth to Groundwater (cm), From 06-05-03 through 11-30-03.

\begin{tabular}{|c|c|c|c|c|c|c|}
\hline \multirow{2}{*}{$\begin{array}{c}\text { Monitoring } \\
\text { Well }\end{array}$} & \multicolumn{7}{|c|}{ Elevation $(\mathrm{cm})$} \\
\cline { 2 - 7 } & $06 / 05 / 03$ & $07 / 08 / 03$ & $08 / 29 / 03$ & $09 / 29 / 03$ & $10 / 29 / 03$ & $11 / 30 / 03$ \\
\hline MW-3B & -34.6 & -43.6 & -32.6 & -27.6 & -47.1 & -37.6 \\
\hline MW-3B & -87.8 & -120.8 & -107.8 & -77.8 & -121.3 & -86.3 \\
\hline MW-3B & -5.3 & -17.3 & -10.3 & -6.3 & -16.8 & -32.3 \\
\hline MW-3B & -58.8 & -76.8 & -68.8 & -53.8 & -61.3 & -57.8 \\
\hline MW-3B & -40.8 & -50.3 & -39.8 & -31.8 & -48.8 & -43.3 \\
\hline MW-3B & -102.0 & -147.0 & -143.0 & -80.0 & -144.0 & -95.0 \\
\hline MW-3B & -54.6 & -76.6 & -69.6 & -53.6 & -59.6 & -55.1 \\
\hline MW-3B & -68.3 & -95.3 & -84.3 & -63.3 & -71.3 & -70.8 \\
\hline MW-3B & -96.0 & -123.5 & -123.0 & -74.0 & -112.5 & -94.0 \\
\hline
\end{tabular}


Table A-15: Summary of Shallow Well Readings, Depth to Groundwater (cm), From 12-16-03 through 05-29-04.

\begin{tabular}{|c|c|c|c|c|c|c|c|}
\hline \multirow{2}{*}{$\begin{array}{c}\text { Monitoring } \\
\text { Well }\end{array}$} & \multicolumn{7}{|c|}{ Elevation $(\mathrm{cm})$} \\
\cline { 2 - 8 } & $12 / 16 / 03$ & $01 / 30 / 04$ & $02 / 27 / 04$ & $03 / 29 / 04$ & $04 / 29 / 04$ & $05 / 28 / 04$ & $05 / 29 / 04$ \\
\hline MW-3B & -47.1 & -52.1 & -47.6 & -46.6 & -44.6 & -28.1 & -23.6 \\
\hline MW-3B & -100.8 & -114.8 & -98.8 & -104.8 & -102.8 & -75.8 & -66.8 \\
\hline MW-3B & -16.8 & -21.3 & -20.3 & -16.3 & -14.3 & -1.3 & -6.3 \\
\hline MW-3B & -63.8 & -65.3 & -63.8 & -61.8 & -64.8 & -42.8 & -37.8 \\
\hline MW-3B & -48.8 & -56.8 & -56.8 & -51.8 & -55.8 & -37.8 & -39.8 \\
\hline MW-3B & -119.0 & -137.0 & -116.0 & -127.0 & -123.0 & -57.0 & -38.5 \\
\hline MW-3B & -58.1 & -61.6 & -60.6 & -59.6 & -61.6 & -40.6 & -38.6 \\
\hline MW-3B & -78.3 & -90.3 & -82.3 & -83.3 & -82.3 & -63.3 & -64.3 \\
\hline MW-3B & -107.5 & -115.0 & -111.0 & -117.0 & -113.0 & -57.0 & -48.0 \\
\hline
\end{tabular}

Table A-16: Summary of Deep Well Readings, Depth to Potentiometric Surface (m), From 10-19-02 through 05-23-03.

\begin{tabular}{|c|c|c|c|c|c|c|}
\hline \multirow{2}{*}{$\begin{array}{c}\text { Monitoring } \\
\text { Well }\end{array}$} & \multicolumn{7}{|c|}{ Elevation $(\mathrm{m})$} \\
\cline { 2 - 7 } & $10 / 19 / 02$ & $11 / 21 / 02$ & $12 / 10 / 02$ & $03 / 19 / 03$ & $04 / 18 / 03$ & $05 / 23 / 03$ \\
\hline MW-3B & 94.49 & 94.54 & 94.48 & 94.51 & 94.51 & 94.58 \\
\hline MW-3B & 93.00 & 93.11 & 93.08 & 92.94 & 92.92 & 93.00 \\
\hline MW-3B & 96.42 & 96.54 & 96.51 & 96.54 & 96.57 & 96.63 \\
\hline MW-3B & 95.14 & 95.23 & 95.25 & 95.10 & 95.10 & 95.18 \\
\hline MW-3B & 94.18 & 94.31 & 94.24 & 94.17 & 94.19 & 94.28 \\
\hline MW-3B & 93.18 & 93.25 & 93.41 & 93.04 & 92.94 & 92.97 \\
\hline MW-3B & 95.72 & 95.82 & 95.87 & 95.90 & 95.67 & 95.76 \\
\hline MW-3B & 96.57 & 96.69 & 96.72 & 96.67 & 96.65 & 96.74 \\
\hline MW-3B & 94.36 & 94.44 & 94.54 & 94.27 & 94.22 & 94.28 \\
\hline
\end{tabular}


Table A-17: Summary of Deep Well Readings, Depth to Potentiometric Surface (m), From 06-05-03 through 11-30-03.

\begin{tabular}{|c|c|c|c|c|c|c|}
\hline \multirow{2}{*}{$\begin{array}{c}\text { Monitoring } \\
\text { Well }\end{array}$} & \multicolumn{7}{|c|}{ Elevation $(\mathrm{m})$} \\
\cline { 2 - 7 } & $06 / 05 / 03$ & $07 / 08 / 03$ & $08 / 29 / 03$ & $09 / 29 / 03$ & $10 / 29 / 03$ & $11 / 30 / 03$ \\
\hline MW-3B & 94.63 & 94.54 & 94.65 & 94.70 & 94.50 & 94.60 \\
\hline MW-3B & 93.09 & 92.76 & 92.89 & 93.19 & 92.76 & 93.11 \\
\hline MW-3B & 96.66 & 96.54 & 96.61 & 96.65 & 96.55 & 96.39 \\
\hline MW-3B & 95.19 & 95.01 & 95.09 & 95.24 & 95.17 & 95.20 \\
\hline MW-3B & 94.30 & 94.21 & 94.31 & 94.39 & 94.22 & 94.28 \\
\hline MW-3B & 93.14 & 92.69 & 92.73 & 93.36 & 92.72 & 93.21 \\
\hline MW-3B & 95.79 & 95.57 & 95.64 & 95.80 & 95.74 & 95.78 \\
\hline MW-3B & 96.78 & 96.51 & 96.62 & 96.83 & 96.75 & 96.75 \\
\hline MW-3B & 94.42 & 94.14 & 94.15 & 94.64 & 94.25 & 94.44 \\
\hline
\end{tabular}

Table A-18: Summary of Deep Well Readings, Depth to Potentiometric Surface (m), From 12-16-034 through 05-29-04.

\begin{tabular}{|c|c|c|c|c|c|c|c|}
\hline \multirow{2}{*}{$\begin{array}{c}\text { Monitoring } \\
\text { Well }\end{array}$} & \multicolumn{7}{|c|}{ Elevation $(\mathrm{m})$} \\
\cline { 2 - 8 } & $12 / 16 / 03$ & $01 / 30 / 04$ & $02 / 27 / 04$ & $03 / 29 / 04$ & $04 / 29 / 04$ & $05 / 28 / 04$ & $05 / 29 / 04$ \\
\hline MW-3B & 94.50 & 94.45 & 94.50 & 94.51 & 94.53 & 94.69 & 94.74 \\
\hline MW-3B & 92.96 & 92.82 & 92.98 & 92.92 & 92.94 & 93.21 & 93.30 \\
\hline MW-3B & 96.55 & 96.50 & 96.51 & 96.55 & 96.57 & 96.70 & 96.65 \\
\hline MW-3B & 95.14 & 95.13 & 95.14 & 95.16 & 95.13 & 95.35 & 95.40 \\
\hline MW-3B & 94.22 & 94.14 & 94.14 & 94.19 & 94.15 & 94.33 & 94.31 \\
\hline MW-3B & 92.97 & 92.79 & 93.00 & 92.89 & 92.93 & 93.59 & 93.77 \\
\hline MW-3B & 95.75 & 95.72 & 95.73 & 95.74 & 95.72 & 95.93 & 95.95 \\
\hline MW-3B & 96.68 & 96.56 & 96.64 & 96.63 & 96.64 & 96.83 & 96.82 \\
\hline MW-3B & 94.30 & 94.23 & 94.27 & 94.21 & 94.25 & 94.81 & 94.90 \\
\hline
\end{tabular}


Appendix B: Grain Size Analysis Data, Hydrometer Test 


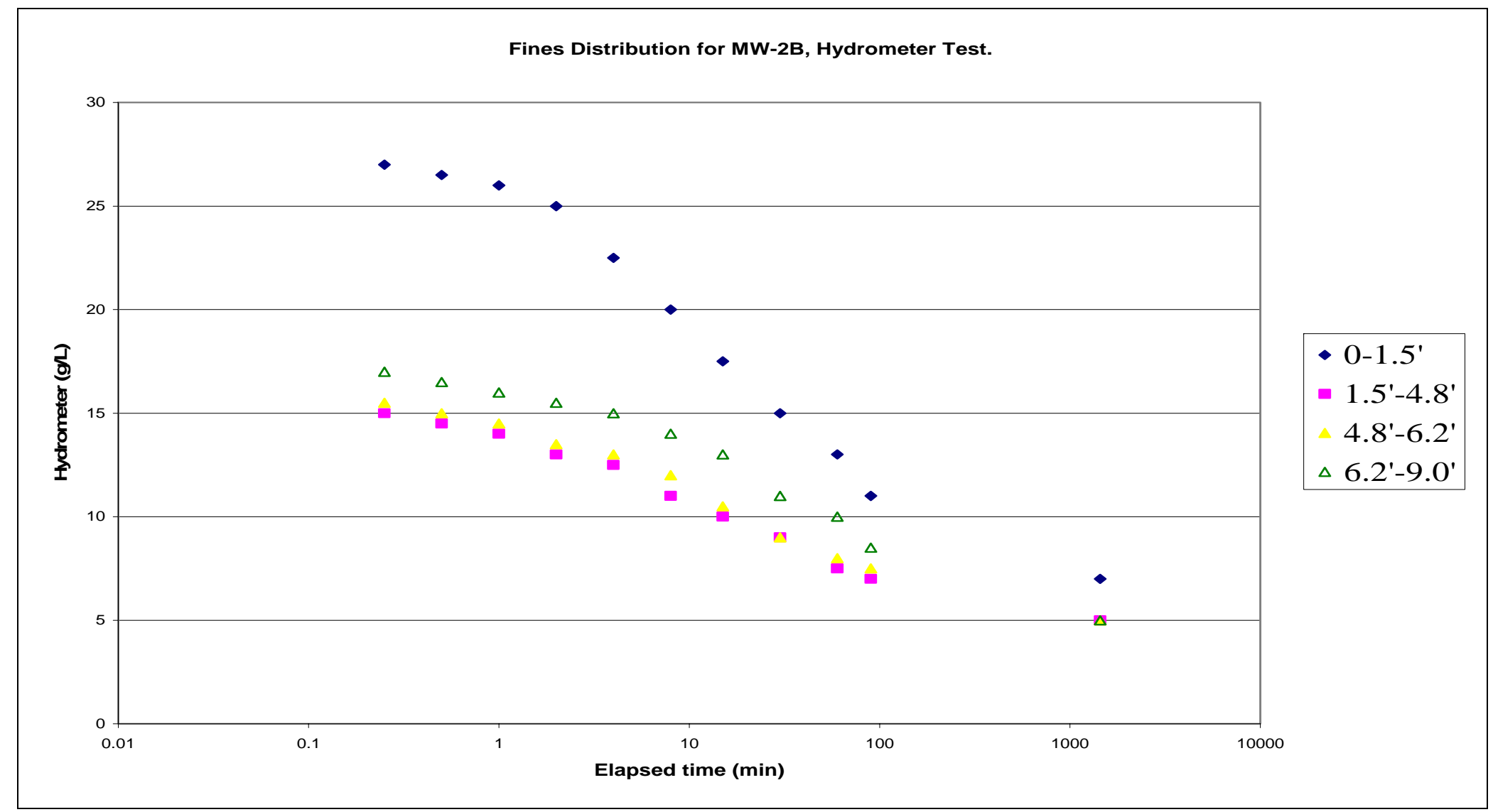

Figure B-1: Fines Distribution Curve for MW-2B. 


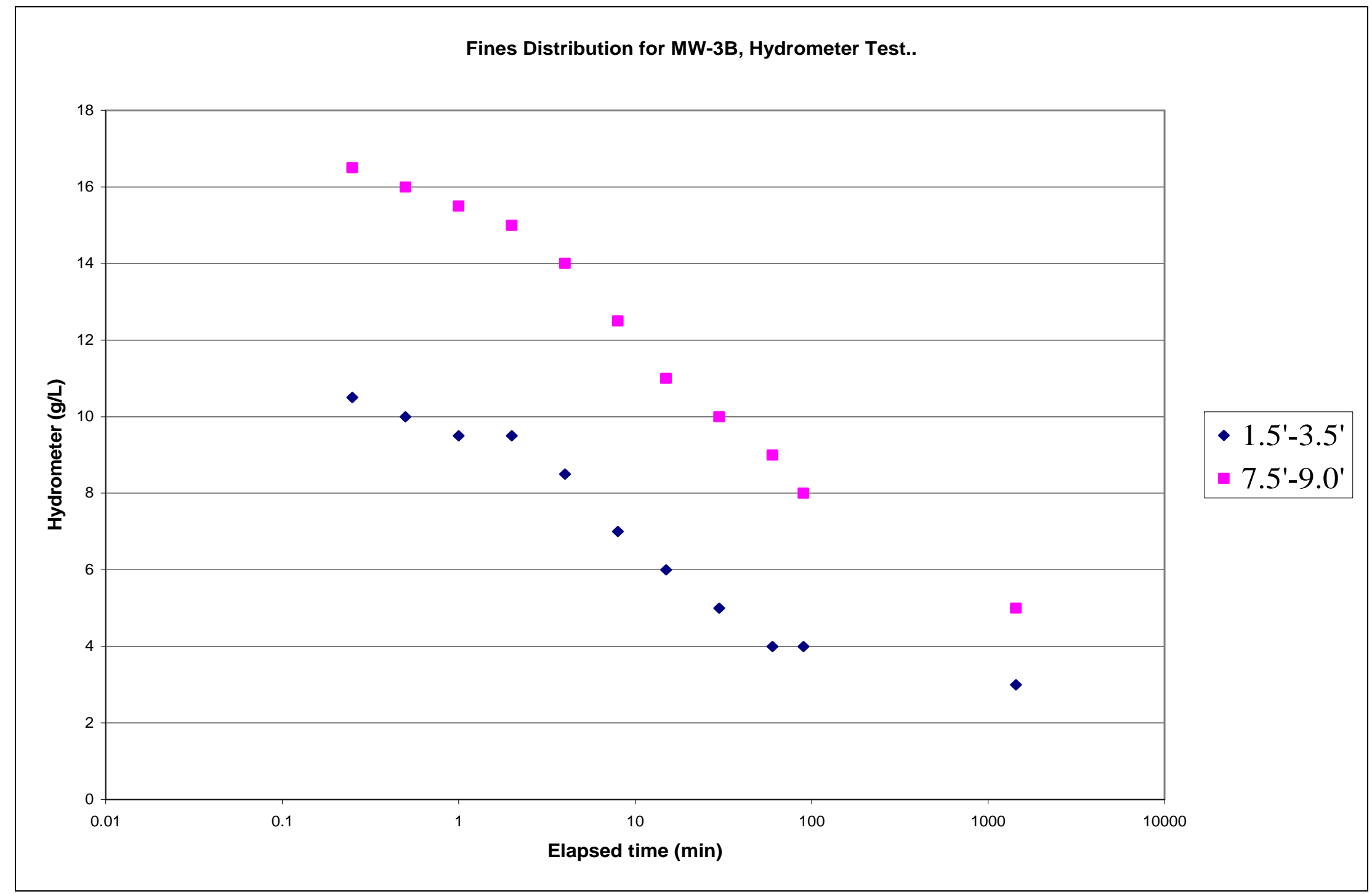

Figure B-2: Fines Distribution Curve for MW-3B. 


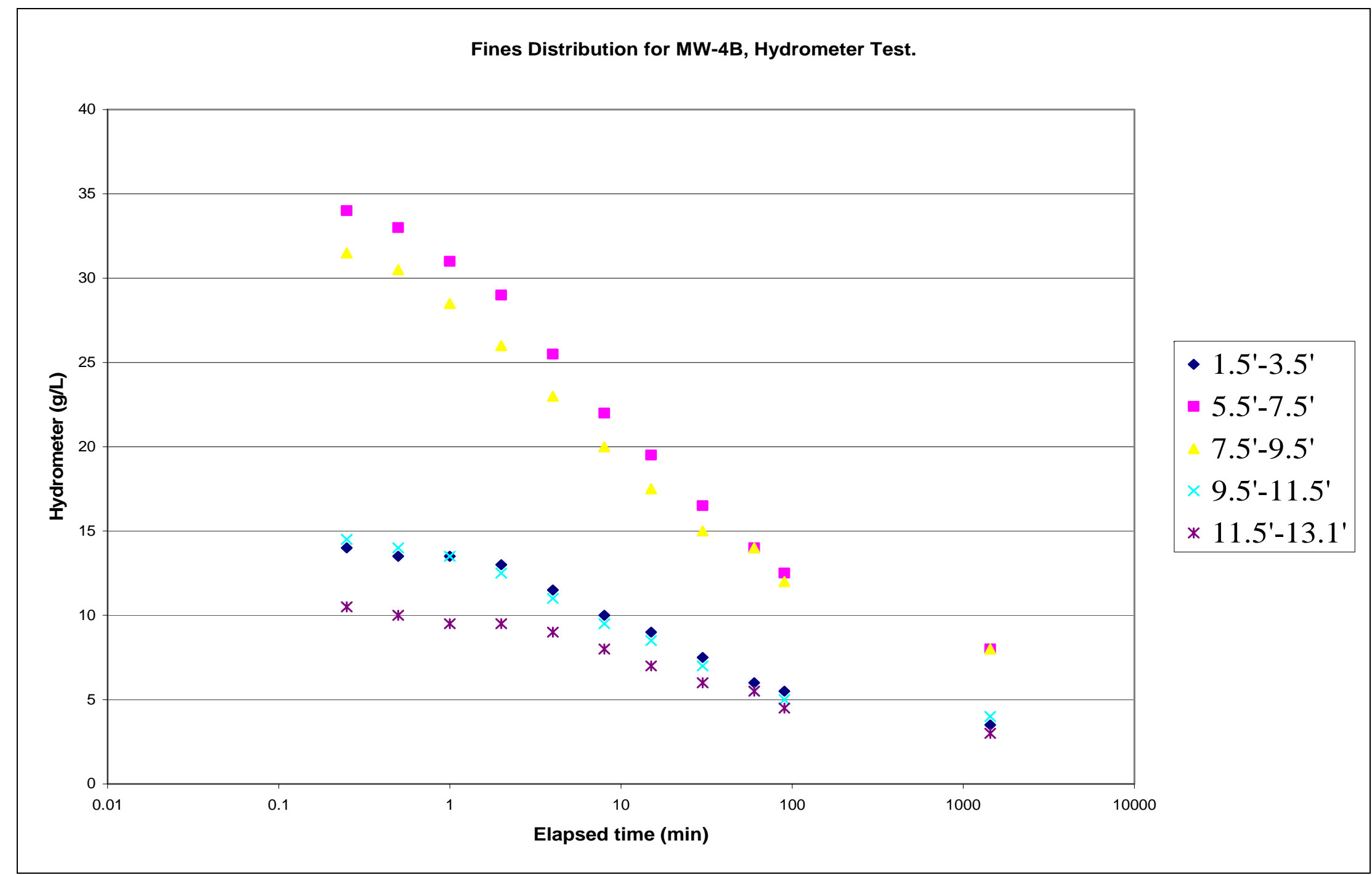

Figure B-3: Fines Distribution Curve for MW-4B. 




Figure B-4: Fines Distribution Curve for MW-6B. 


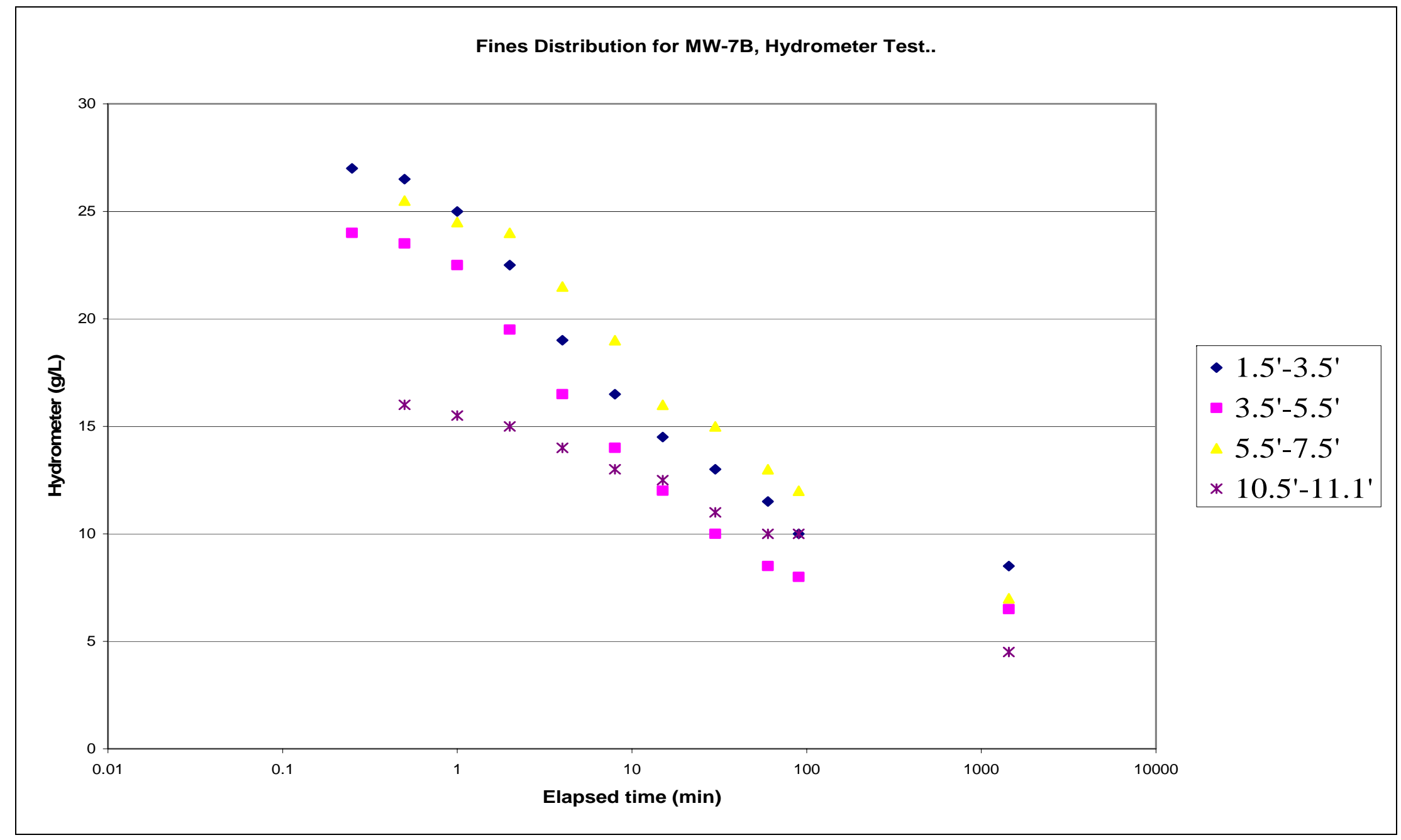

Figure B-5: Fines Distribution Curve for MW-7B. 


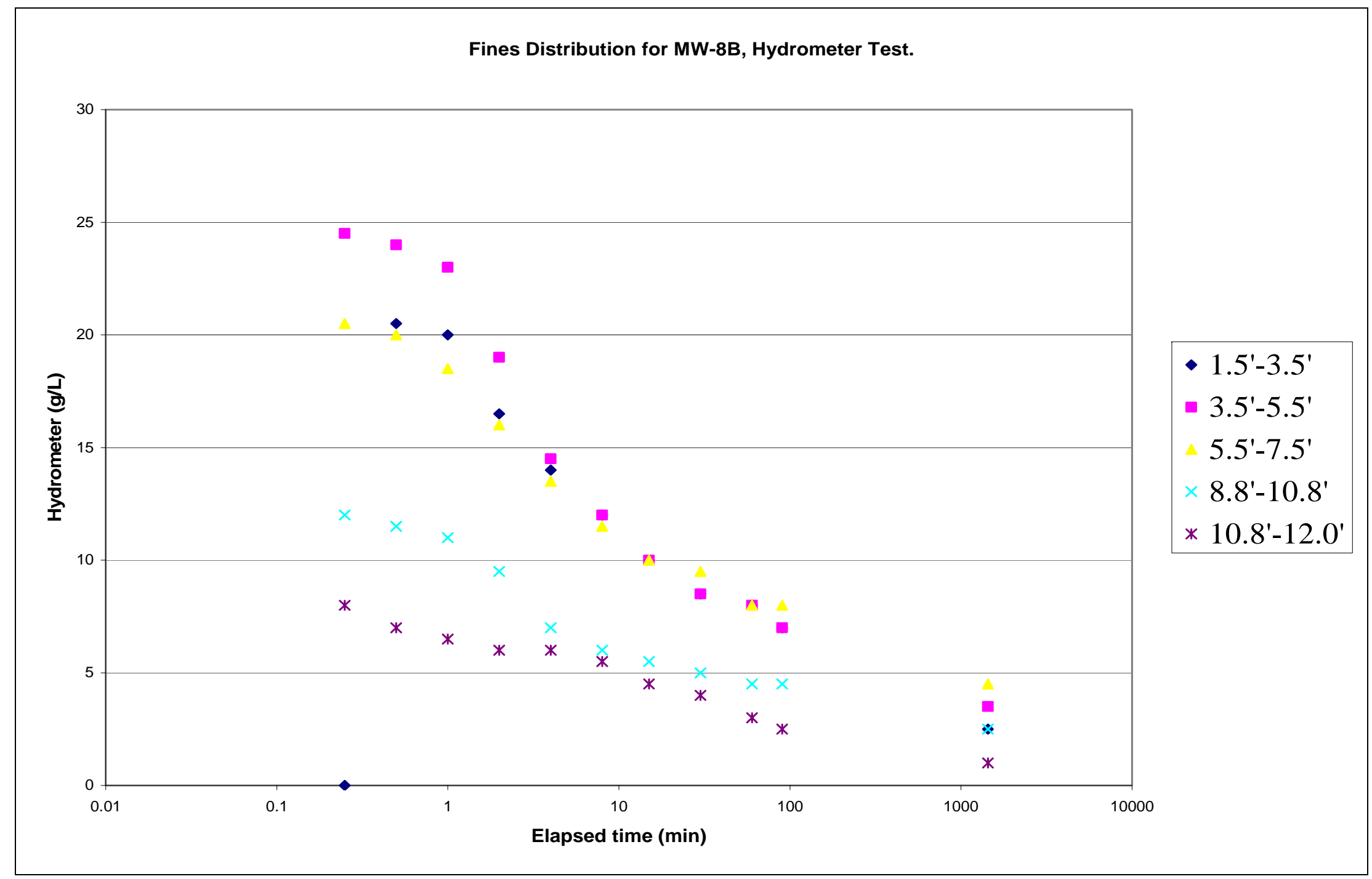

Figure B-6: Fines Distribution Curve for MW-8B. 


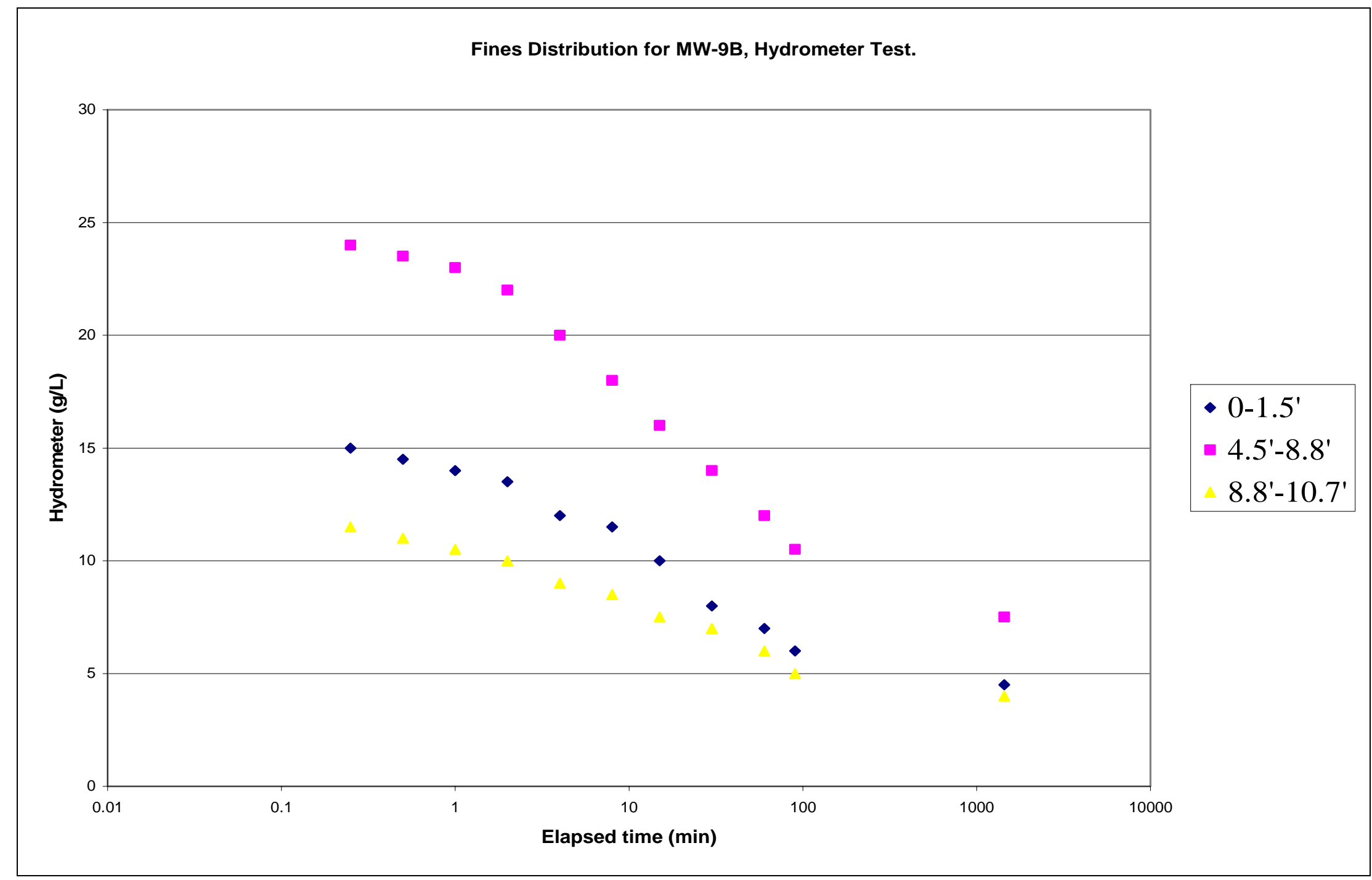

Figure B-7: Fines Distribution Curve for MW-9B. 




Figure B-8: Fines Distribution Curve for MW-10B. 


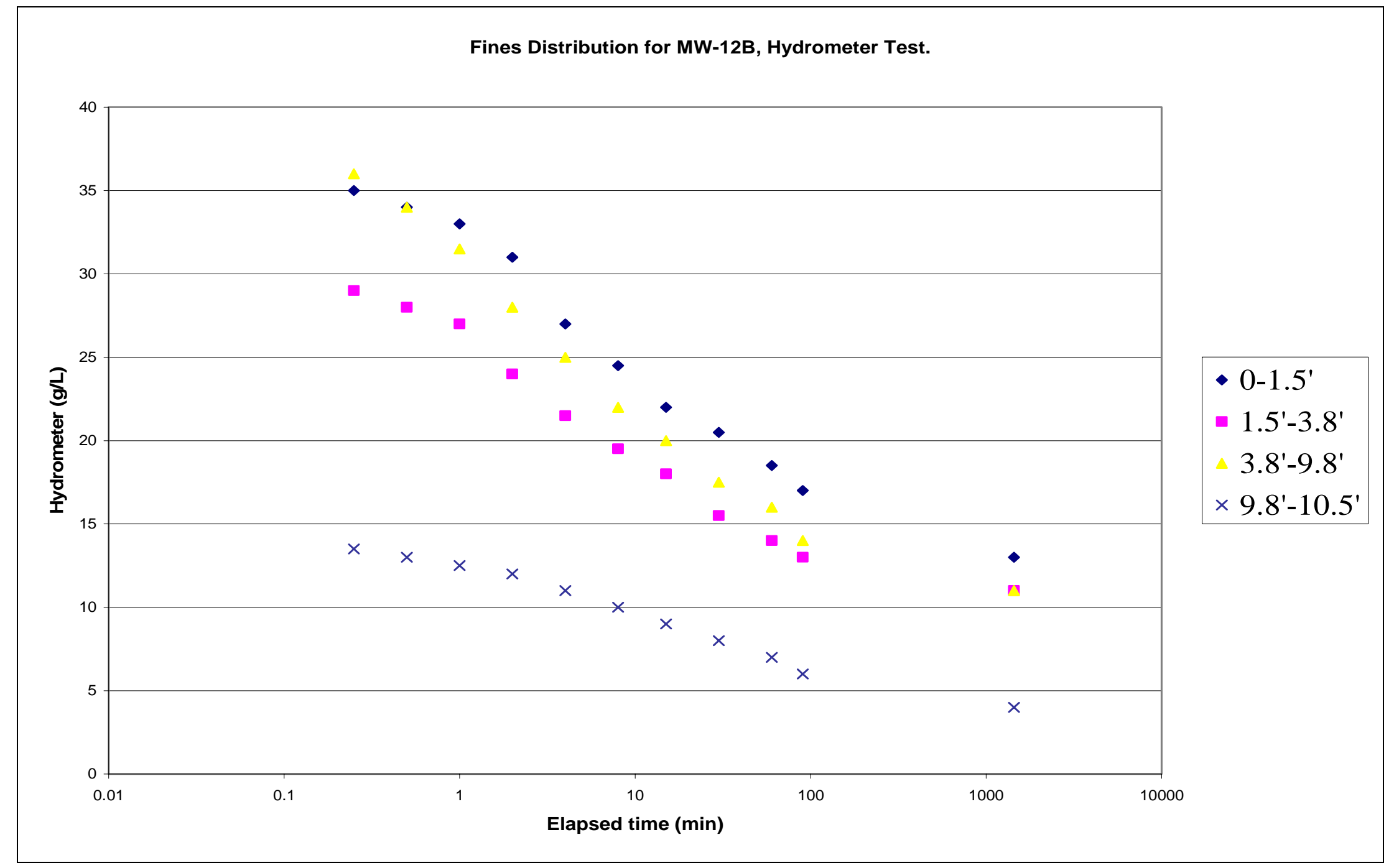

Figure B-9: Fines Distribution Curve for MW-12B. 


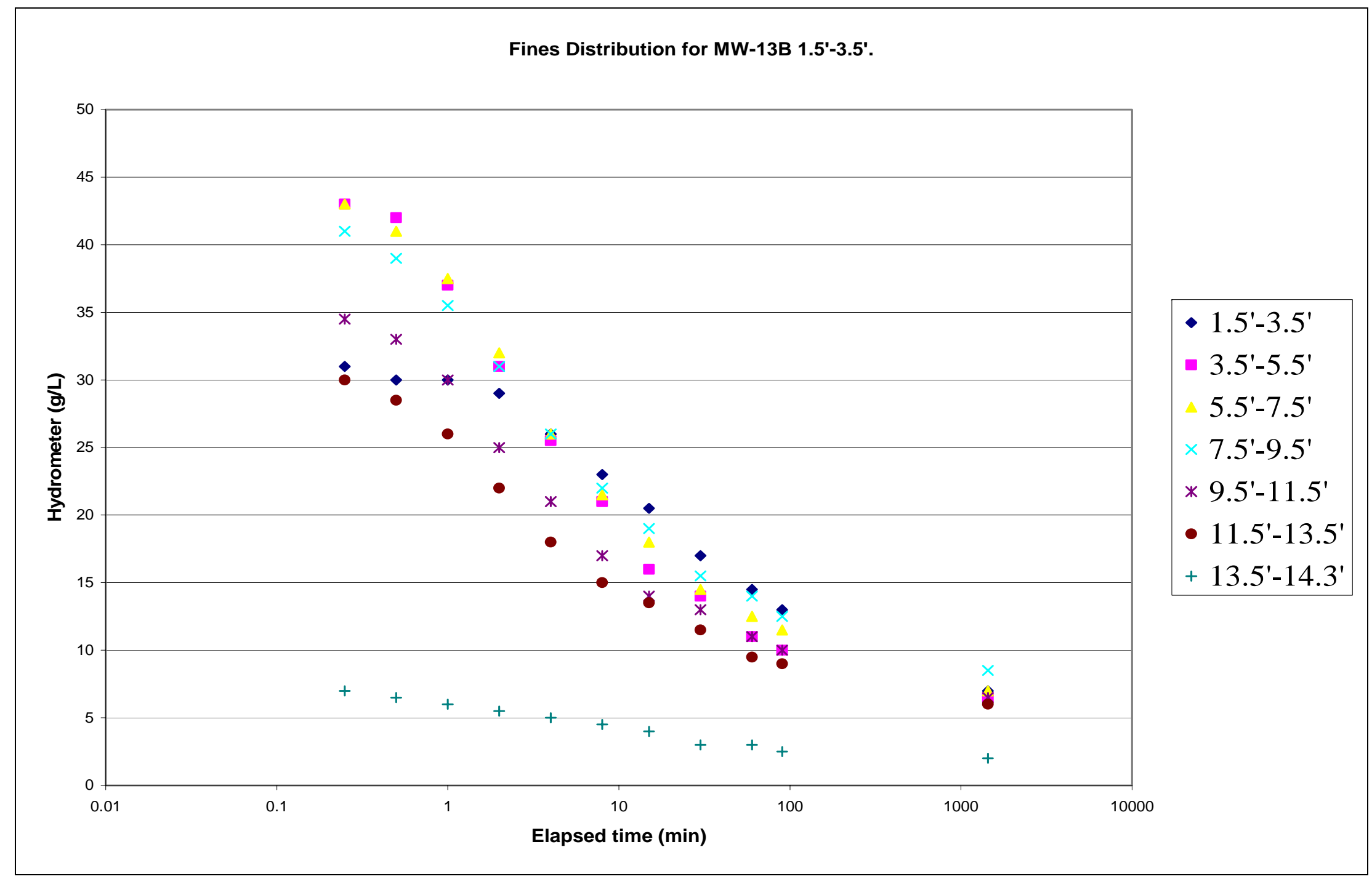

Figure B-10: Fines Distribution Curve for MW-13B. 


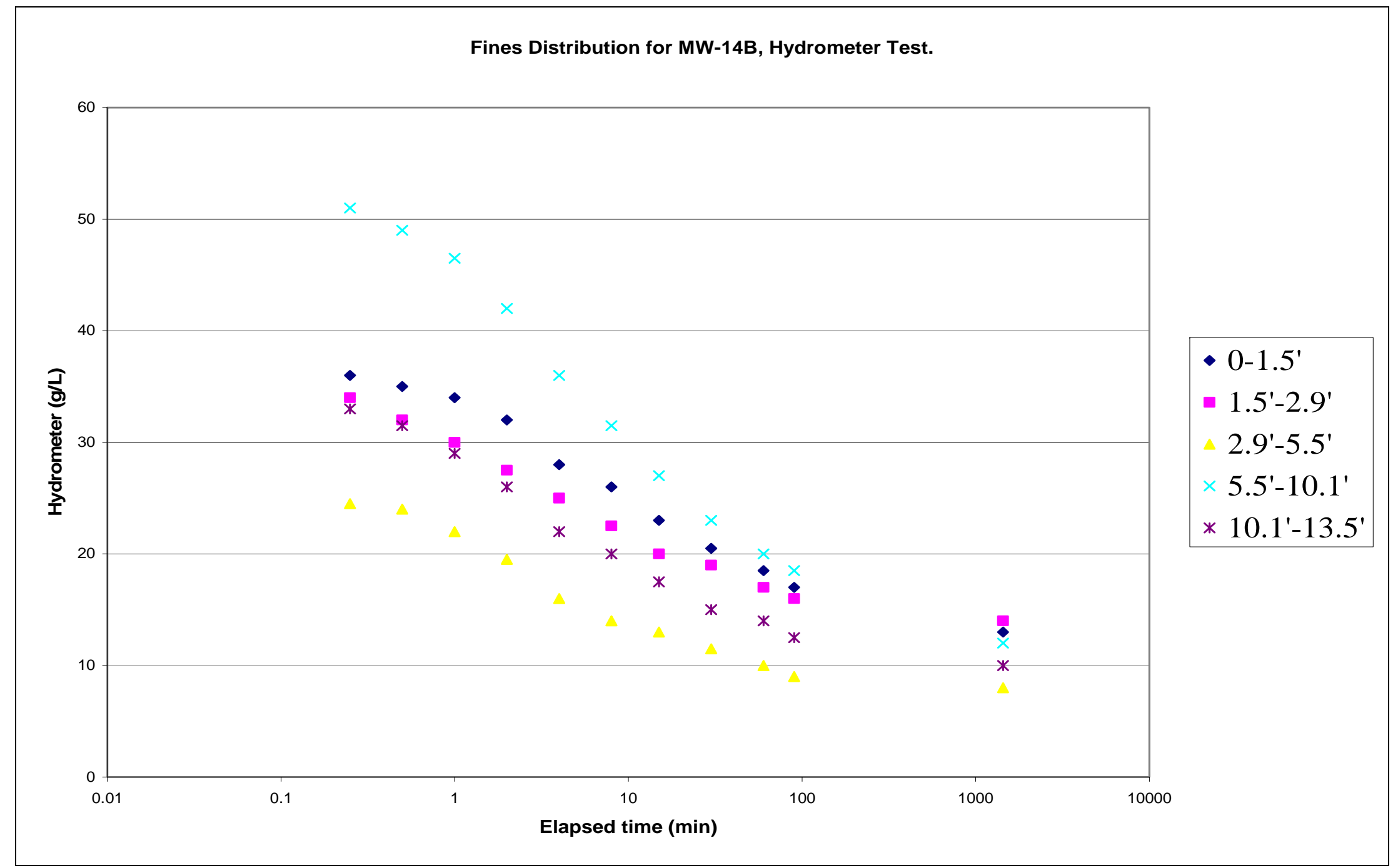

Figure B-11: Fines Distribution Curve for MW-14B. 


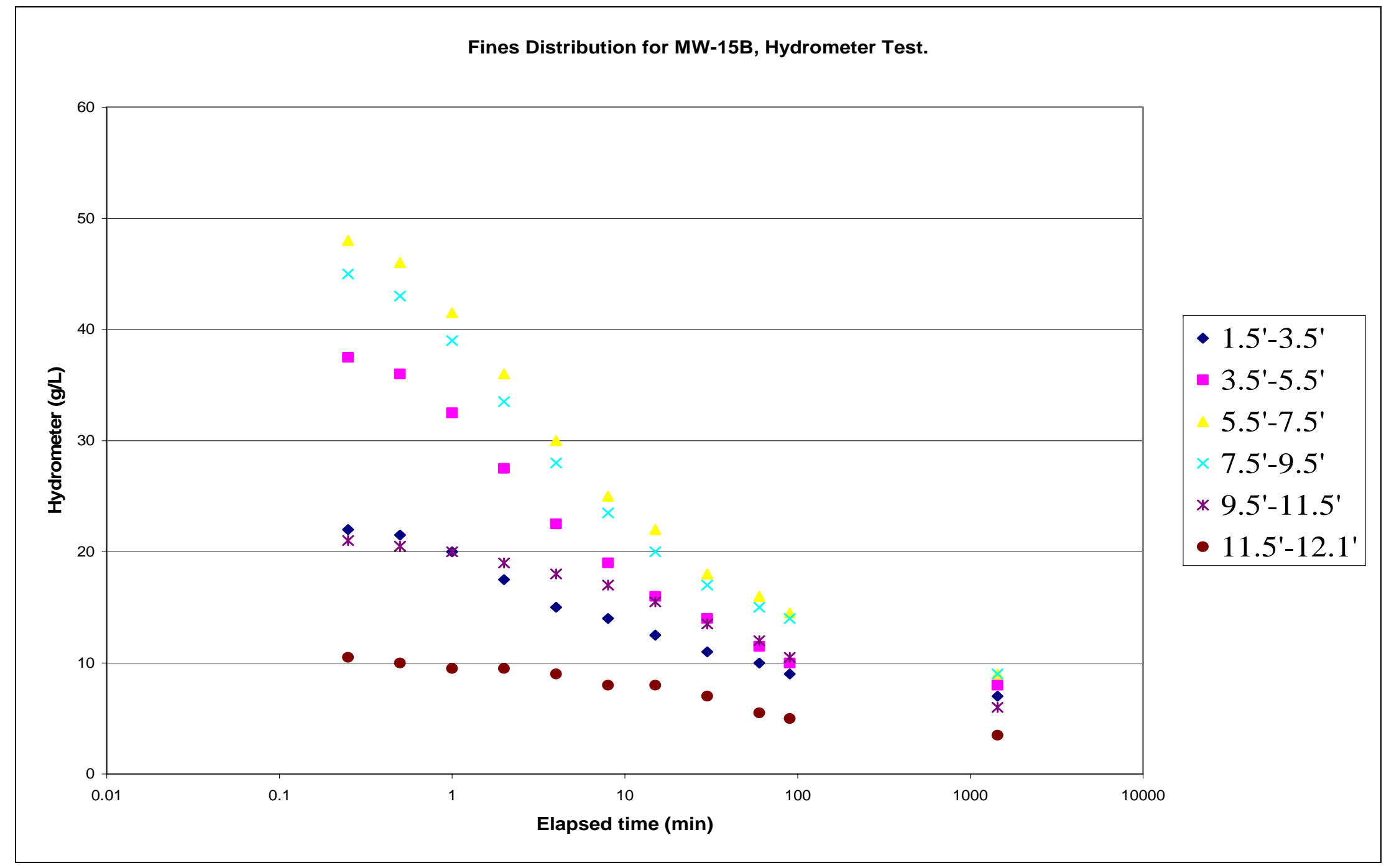

Figure B-12: Fines Distribution Curve for MW-15B. 


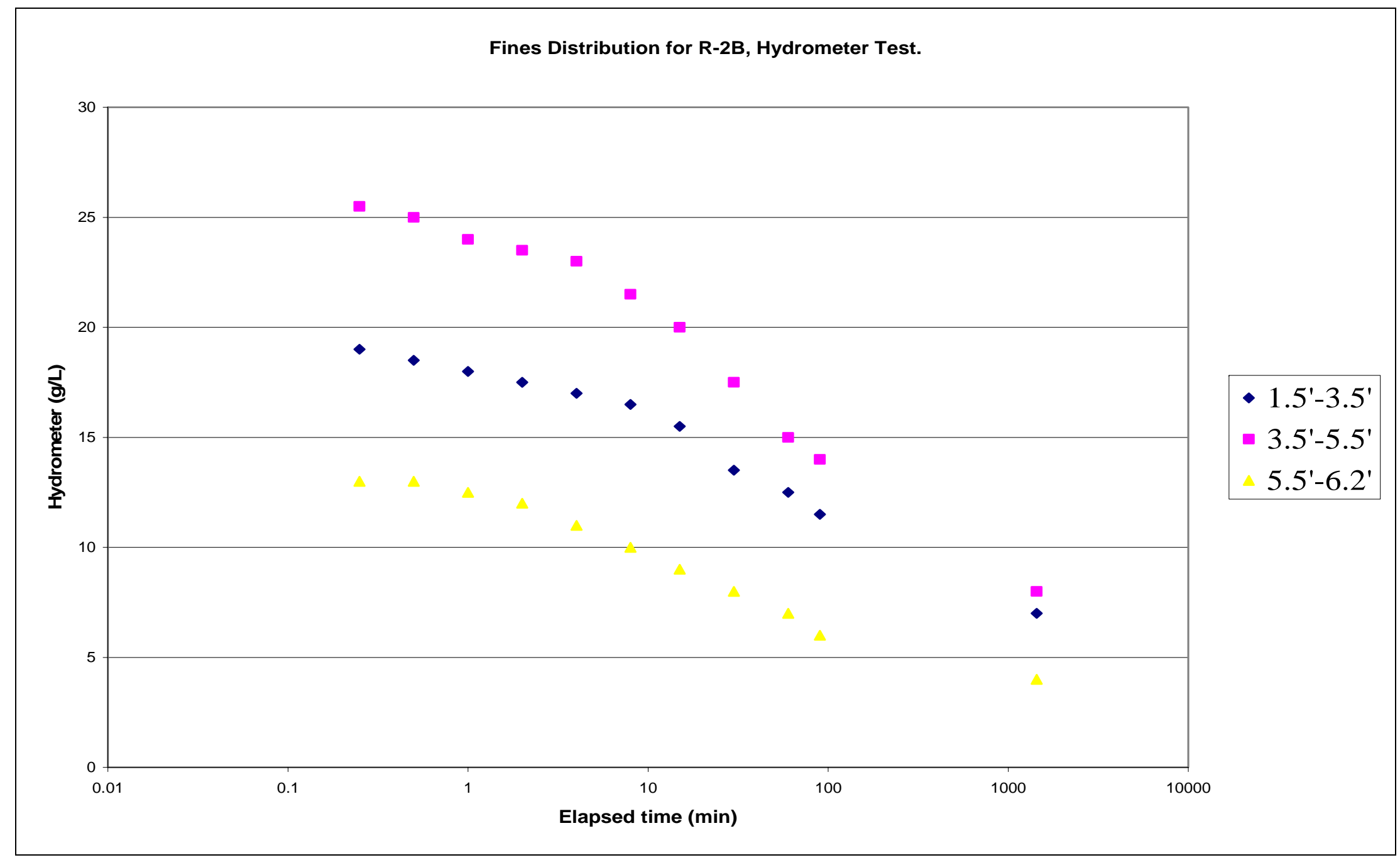

Figure B-13: Fines Distribution Curve for R-2B. 


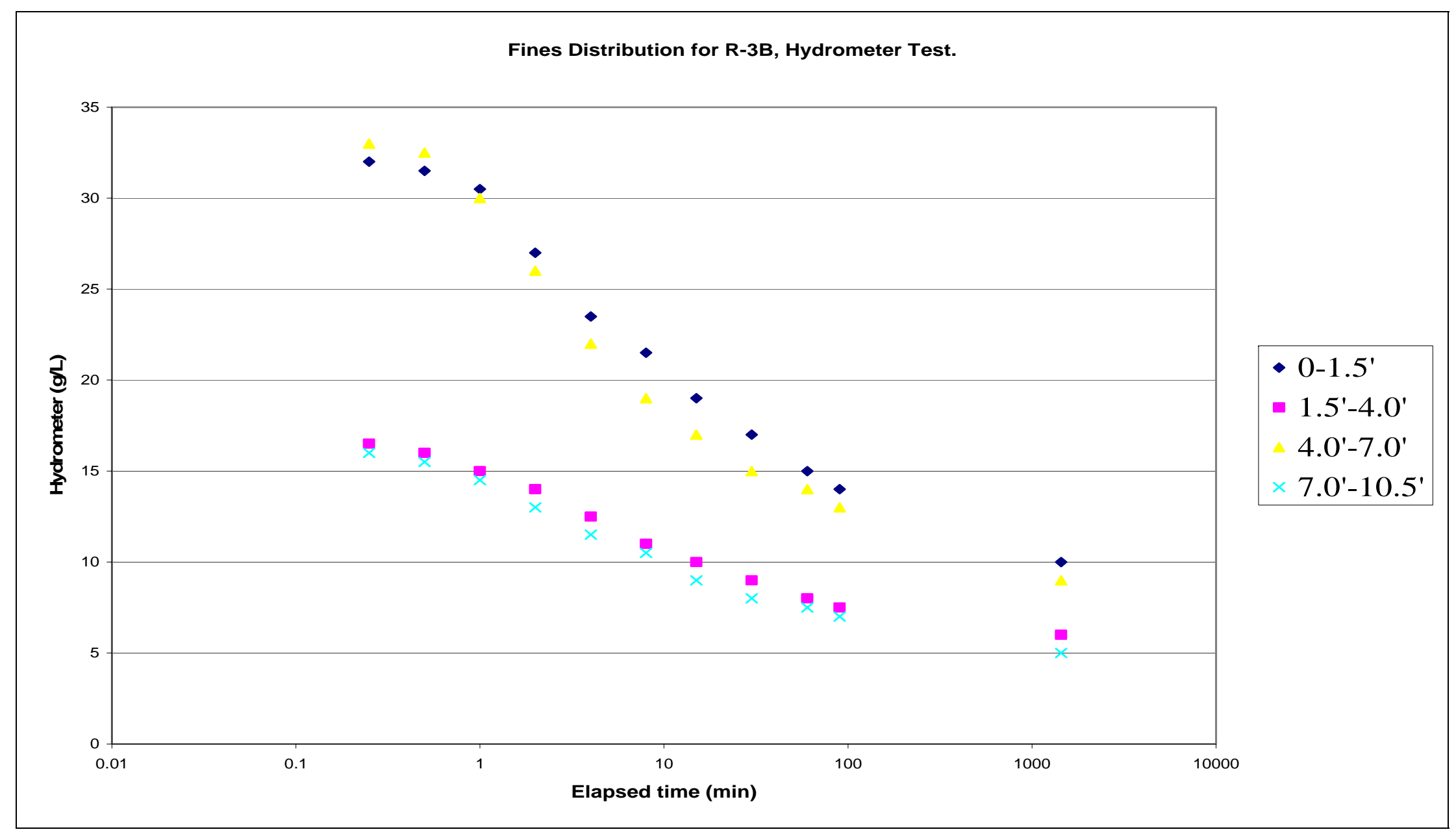

Figure B-14: Fines Distribution Curve for R-3B. 
Appendix C: Montrose Monitoring Well Readings. 


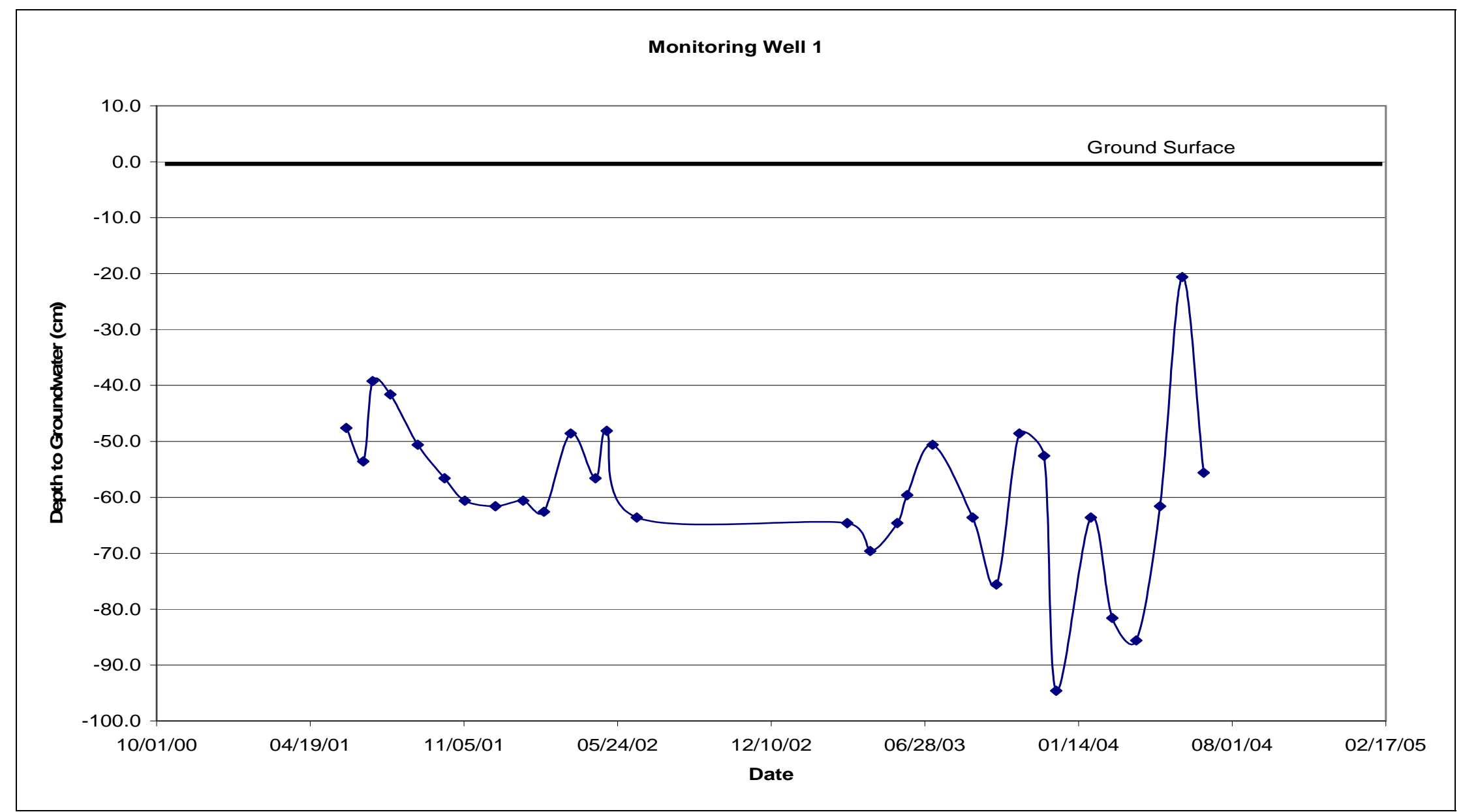

Figure C-1: Well Reading Data for the Monitoring Well 1. 




Figure C-2: Well Reading Data for the Monitoring Well 2. 


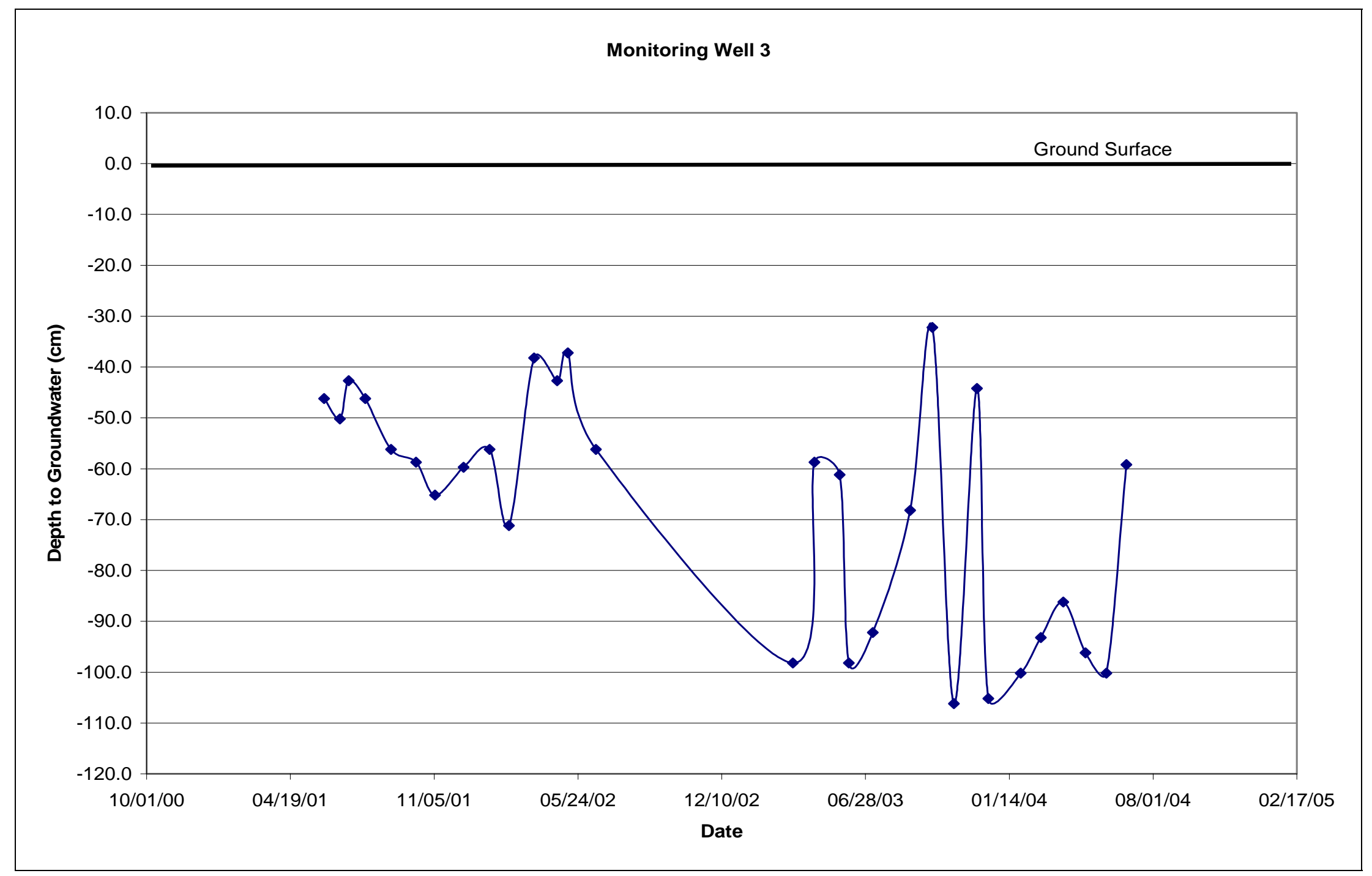

Figure C-3: Well Reading Data for the Monitoring Well 3. 




Figure C-4: Well Reading Data for the Monitoring Well 4. 


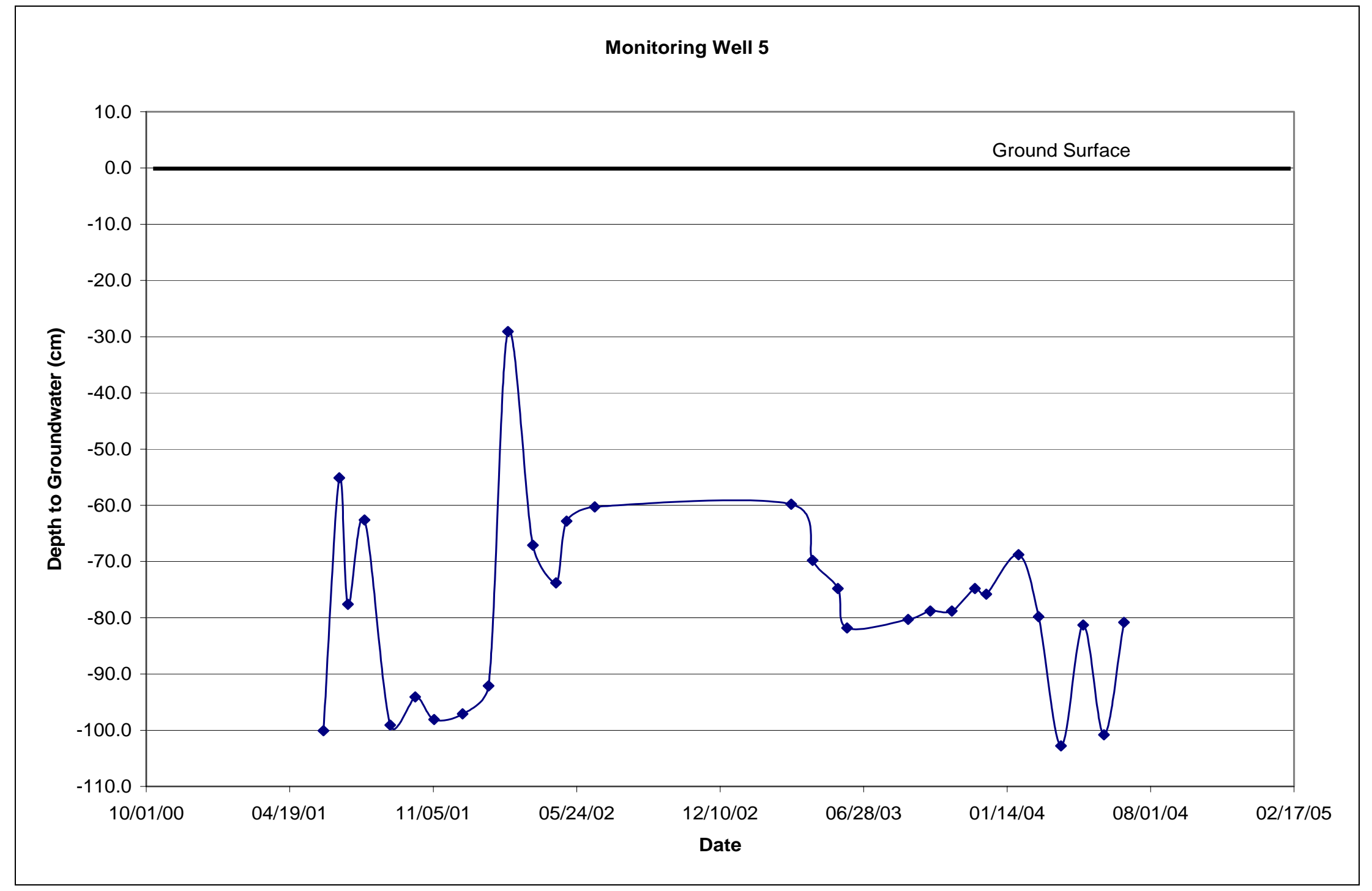

Figure C-5: Well Reading Data for the Monitoring Well 5. 


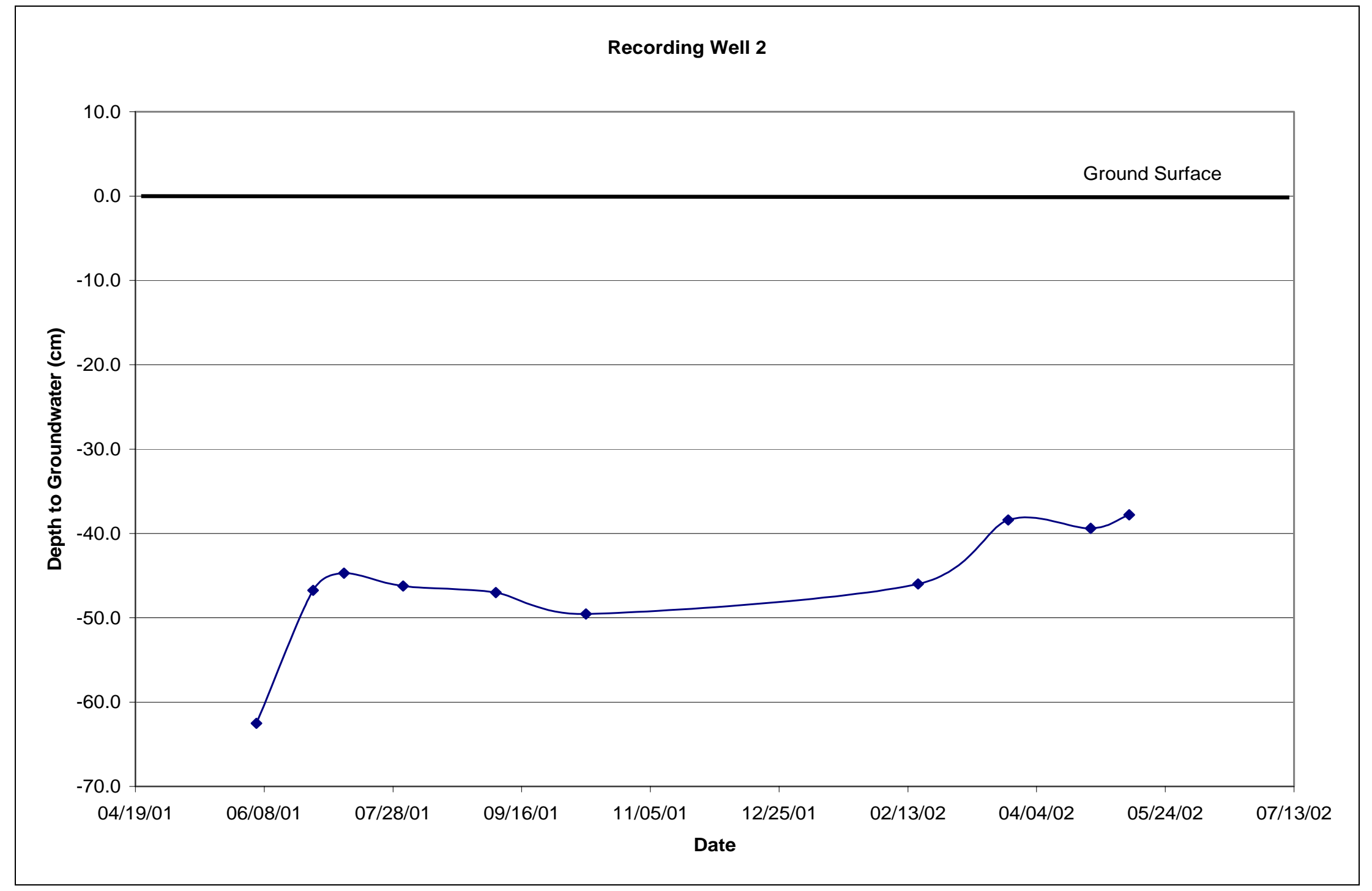

Figure C-6: Well Reading Data for the Recording Well 2. 




Figure C-7: Well Reading Data for the monitoring Well 6. 


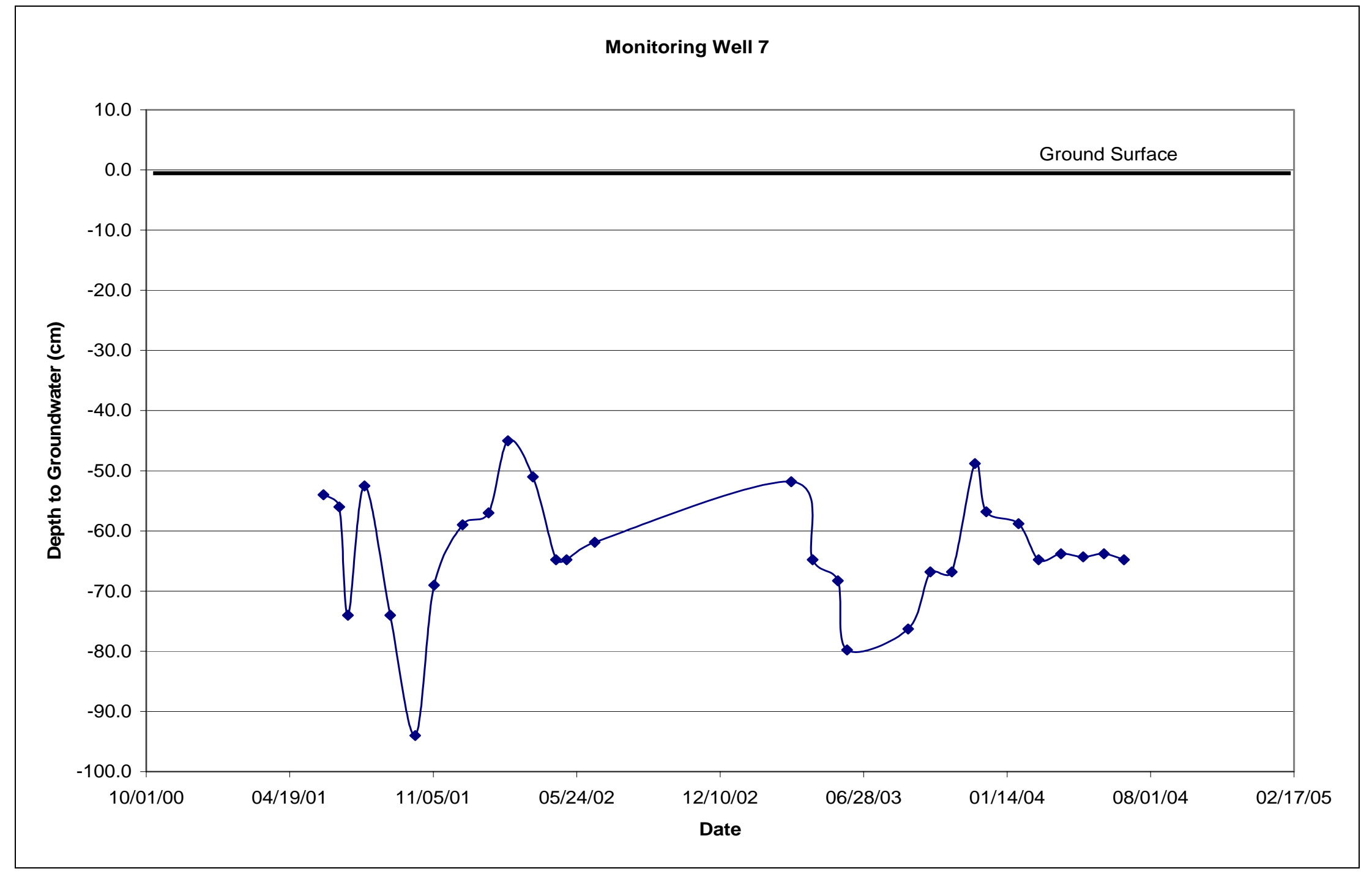

Figure C-8: Well Reading Data for the monitoring Well 7. 


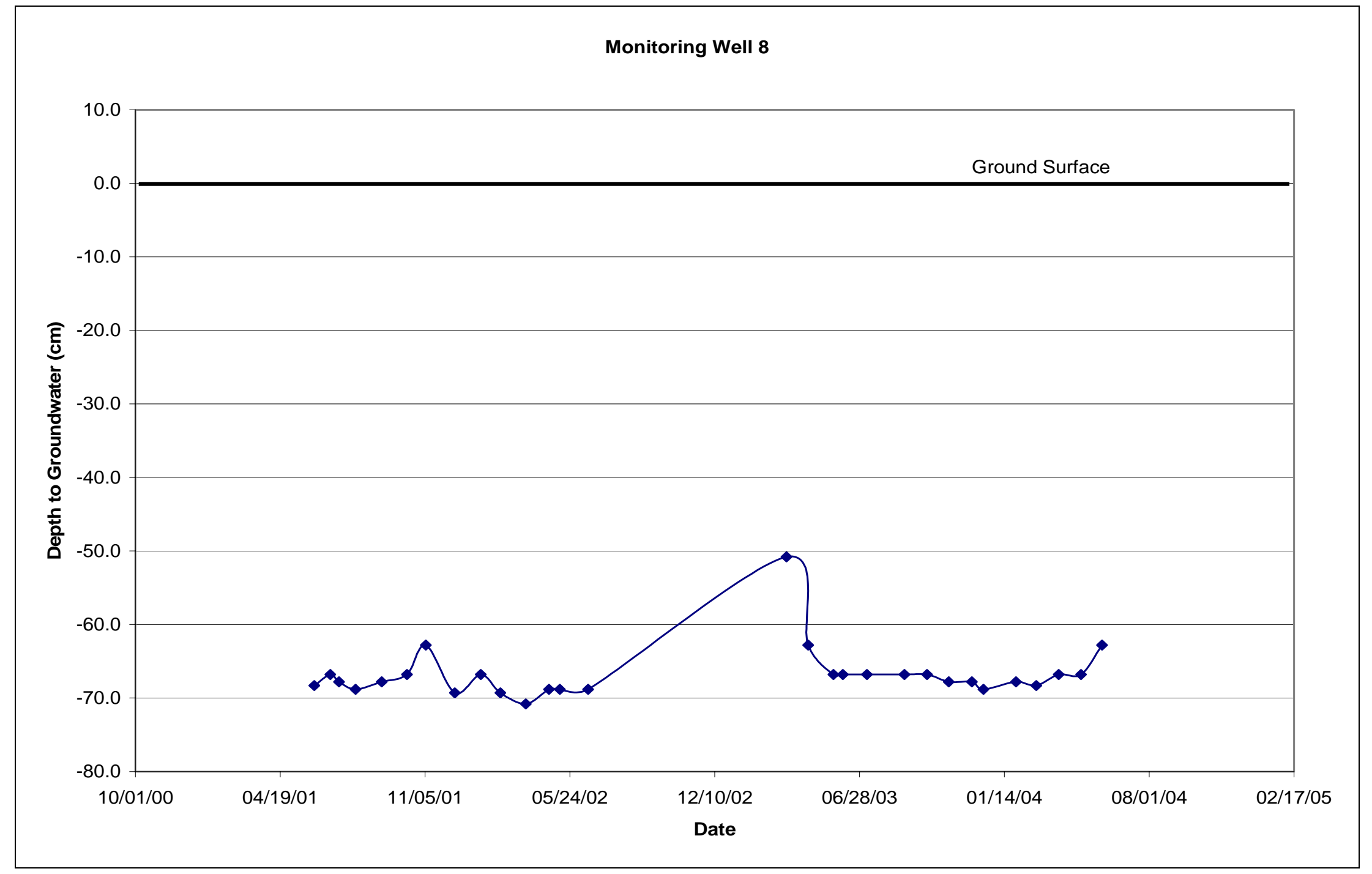

Figure C-9: Well Reading Data for the monitoring Well 8. 


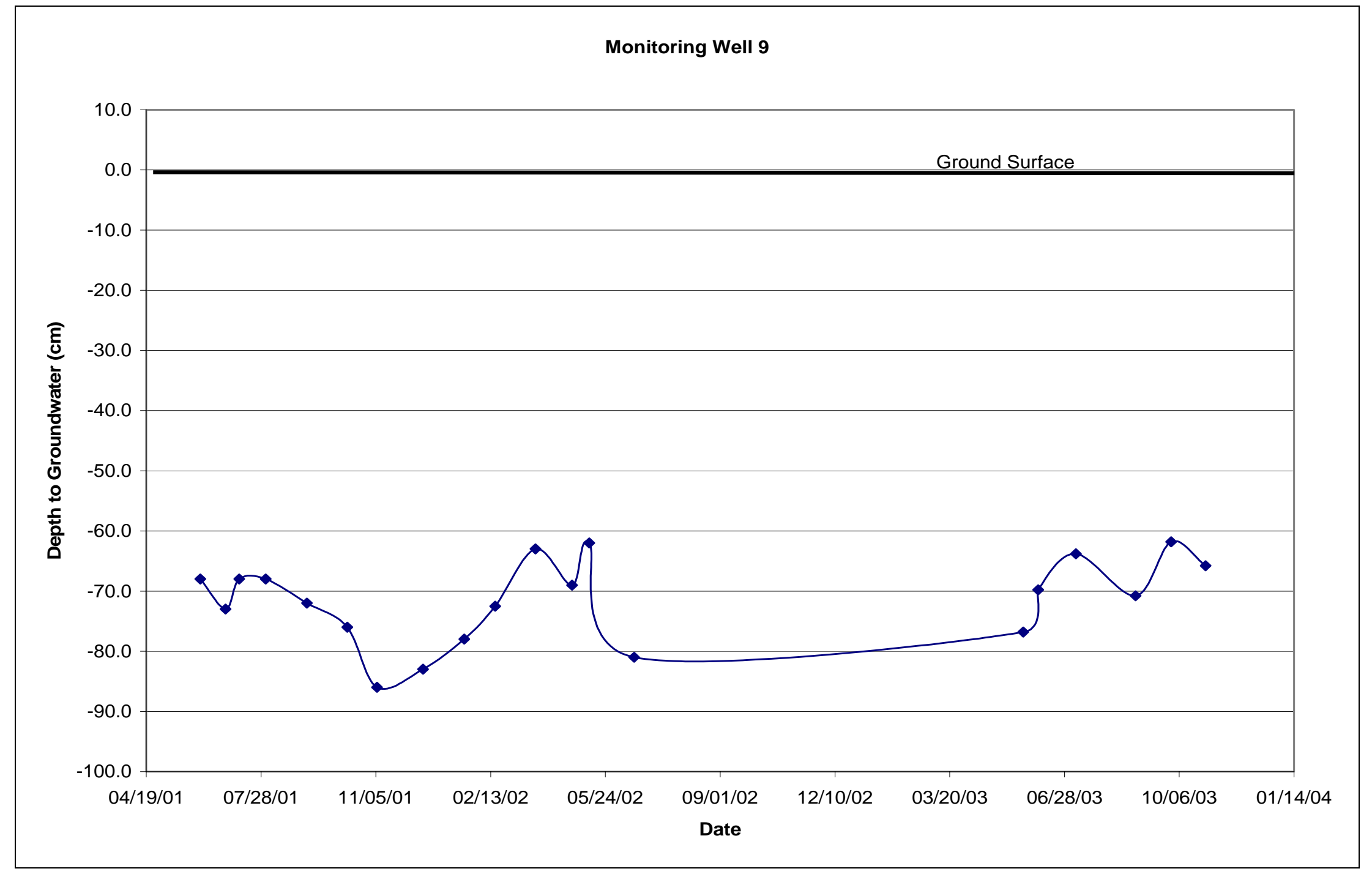

Figure C-10: Well Reading Data for the monitoring Well 9. 


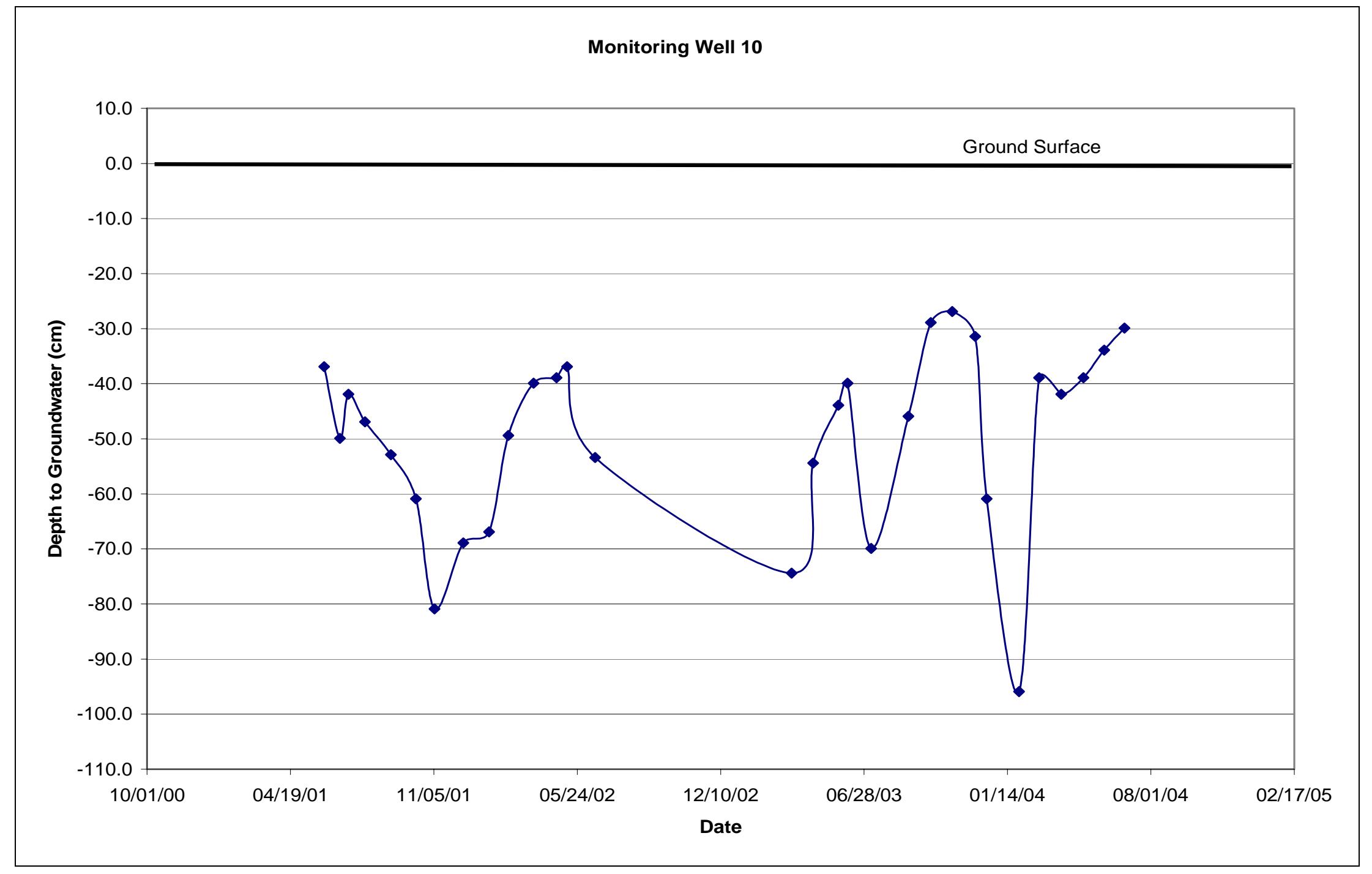

Figure C-11: Well Reading Data for the Monitoring Well 10. 


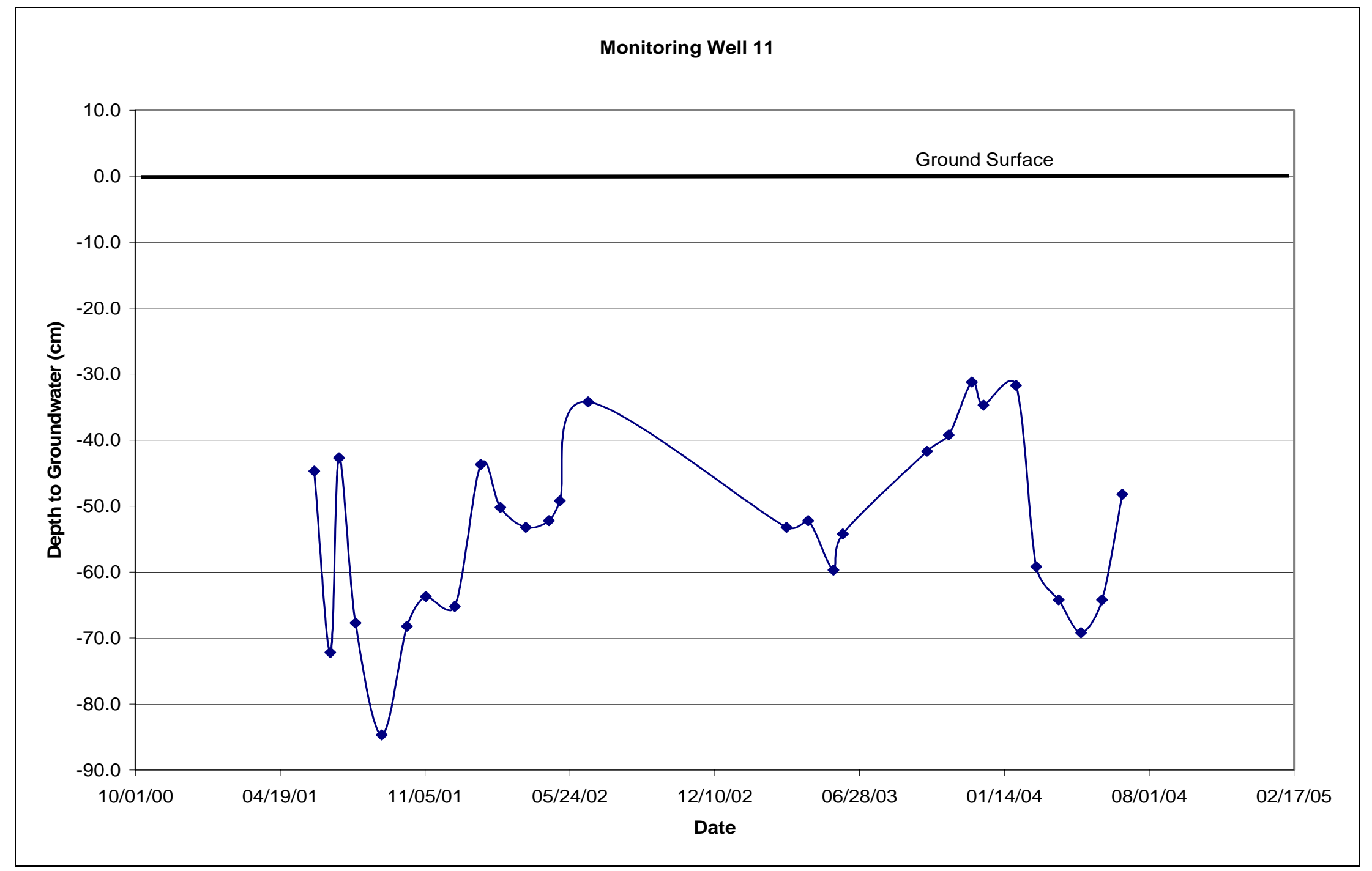

Figure C-12: Well Reading Data for the Monitoring Well 11. 


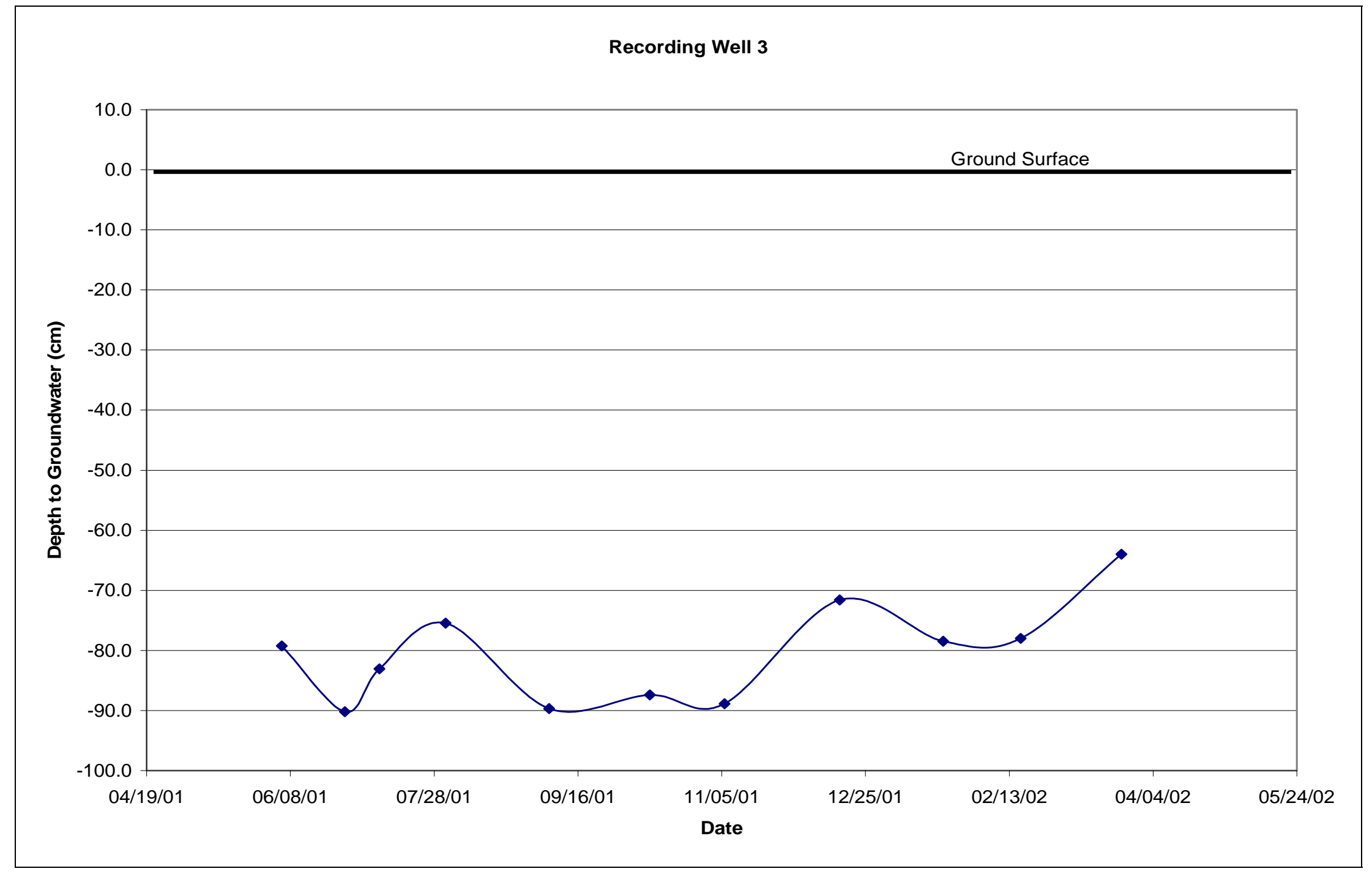

Figure C-13: Well Reading Data for the Recording Well 3. 


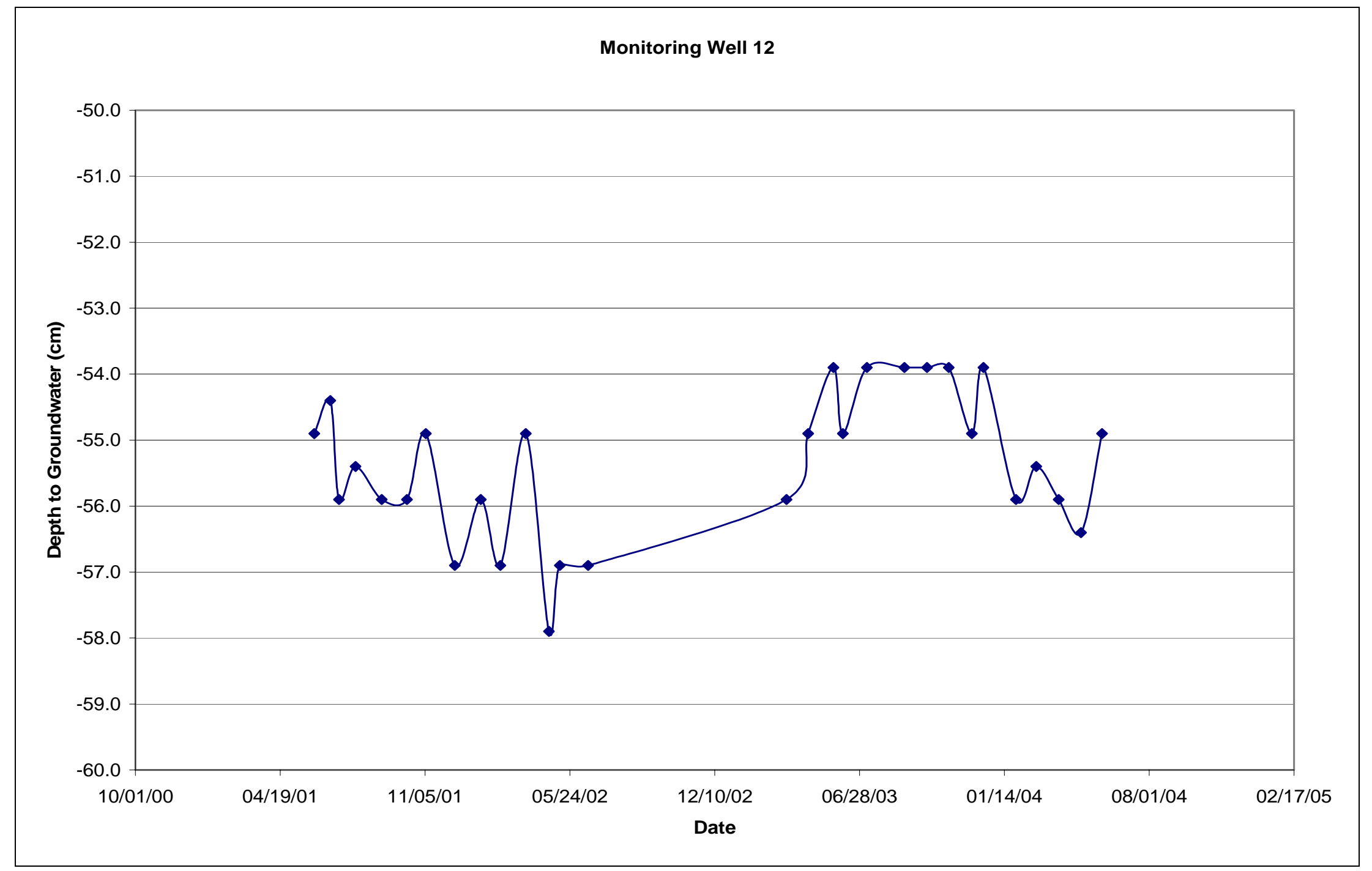

Figure C-14: Well Reading Data for the Monitoring Well 12. 


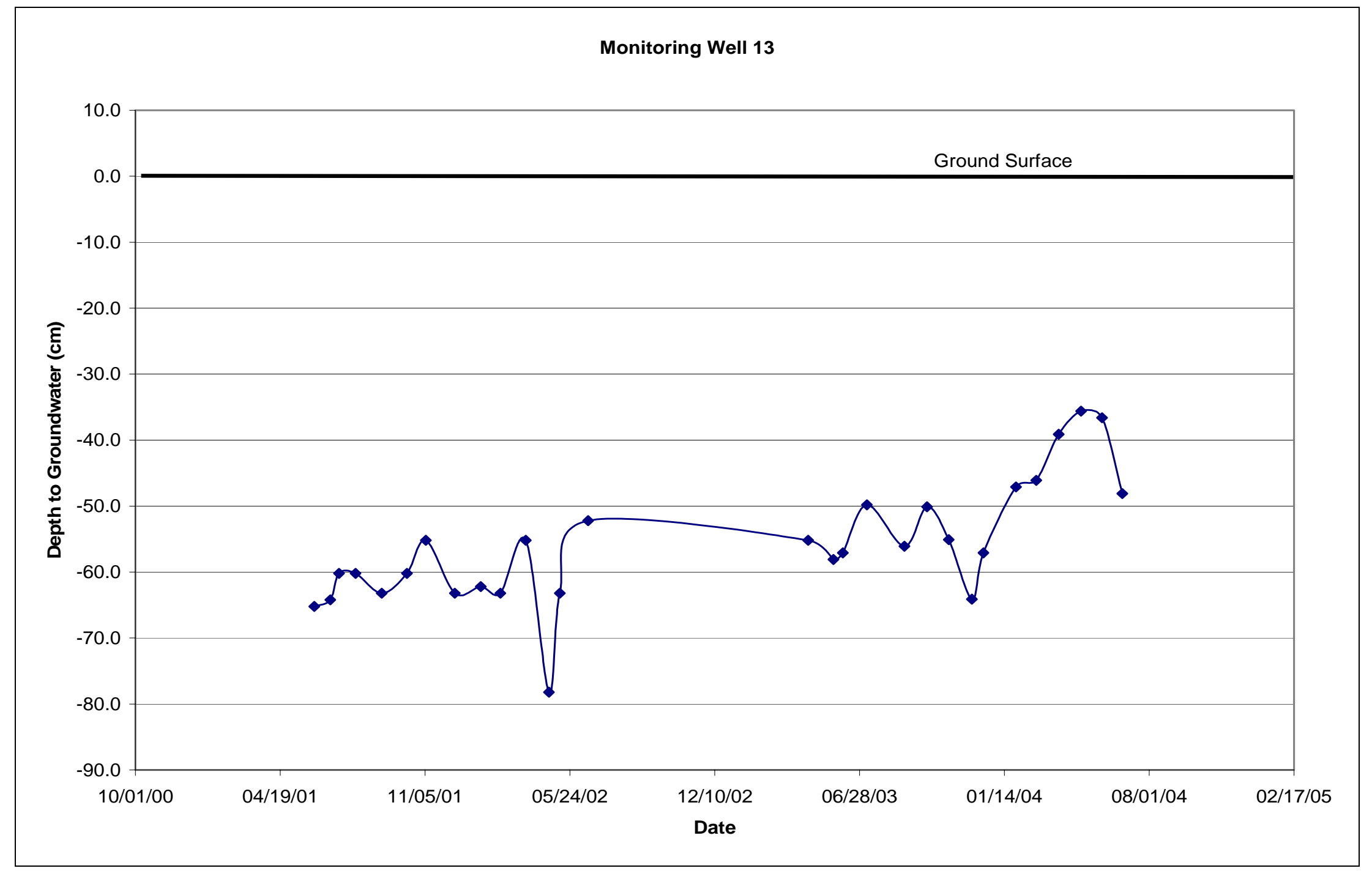

Figure C-15: Well Reading Data for the Monitoring Well 13. 


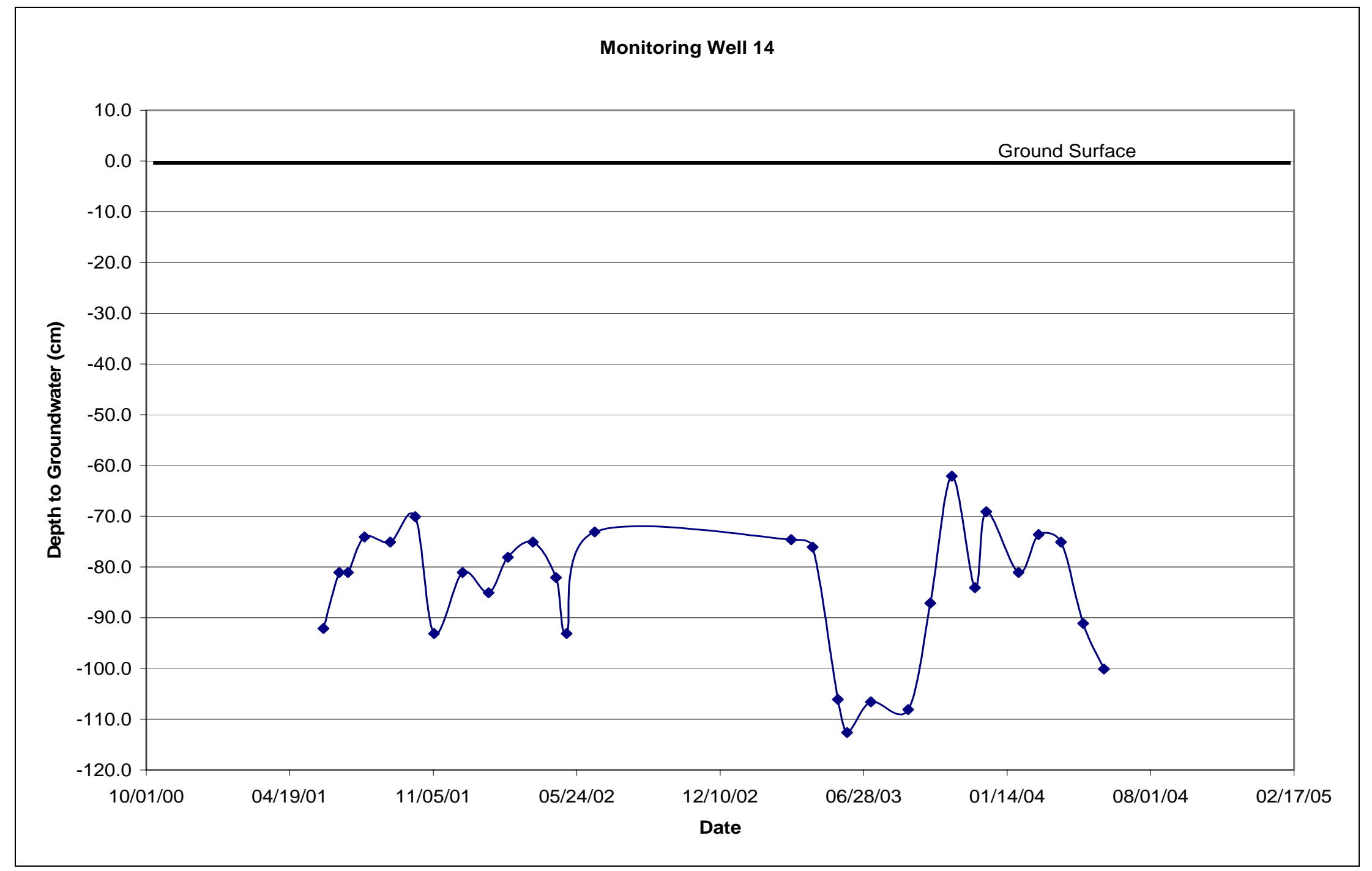

Figure C-16: Well Reading Data for the Monitoring Well 14. 


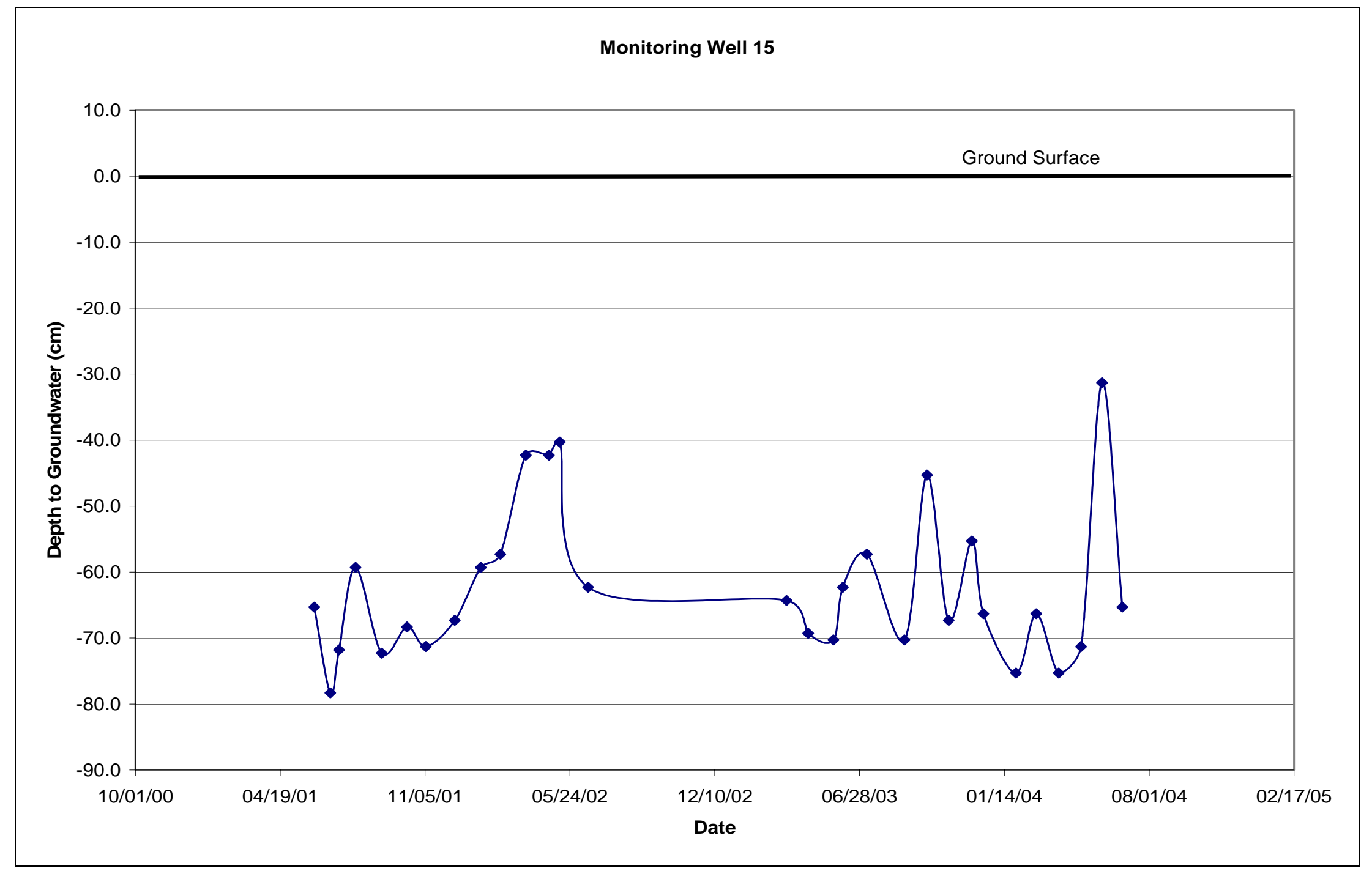

Figure C-17: Well Reading Data for the Monitoring Well 15. 


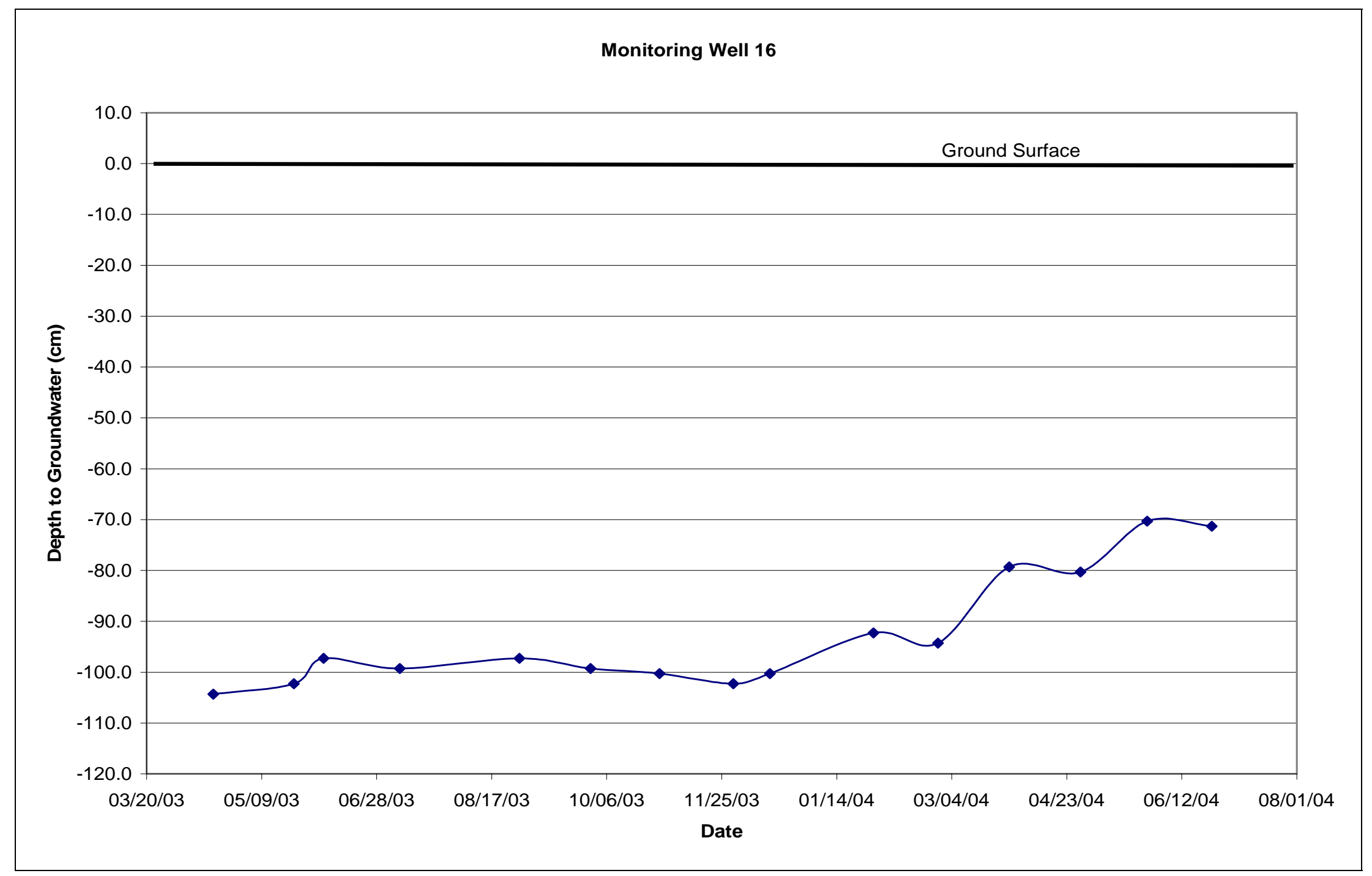

Figure C-18: Well Reading Data for the Monitoring Well 16. 


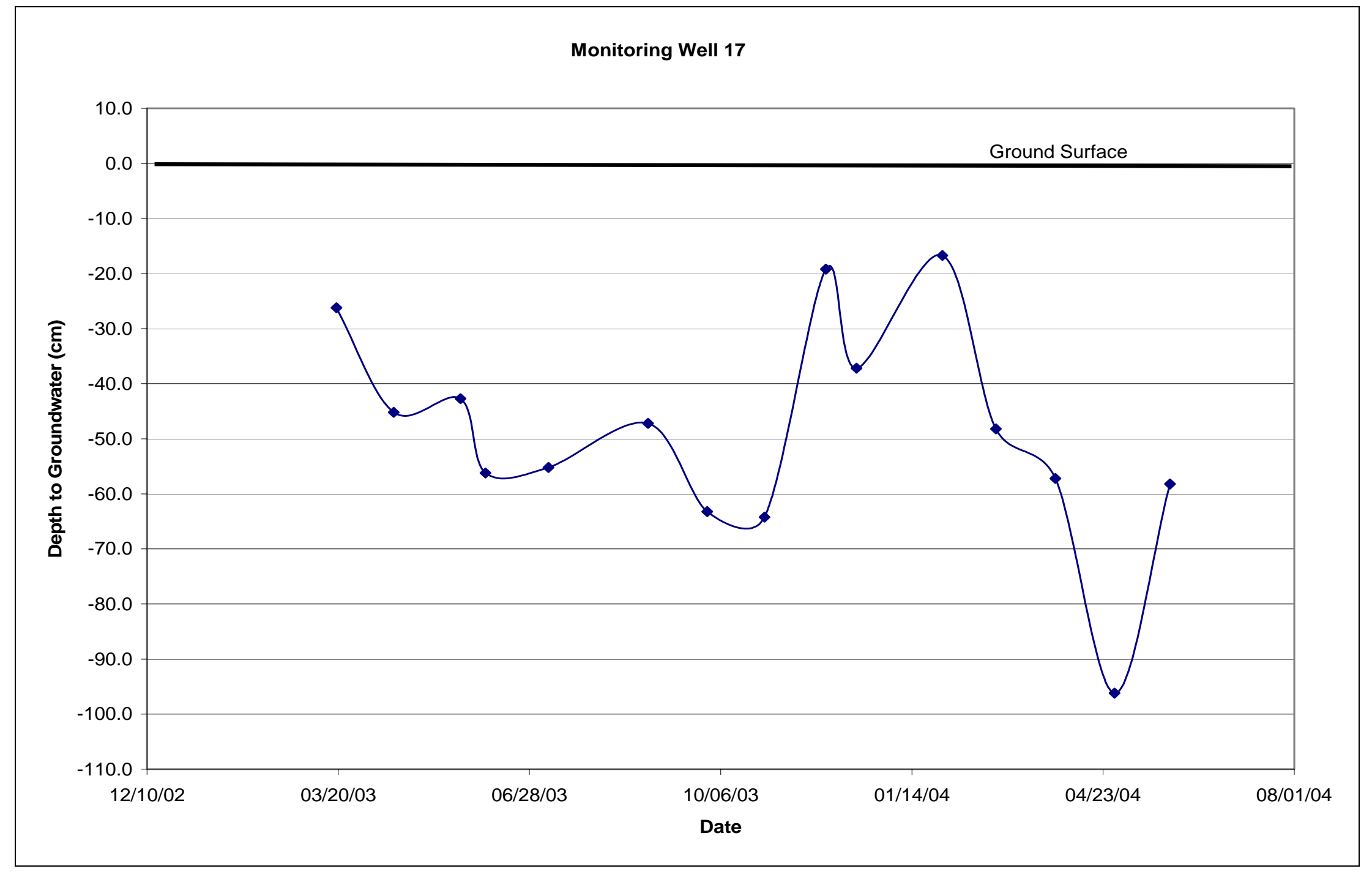

Figure C-19: Well Reading Data for the Monitoring Well 17. 


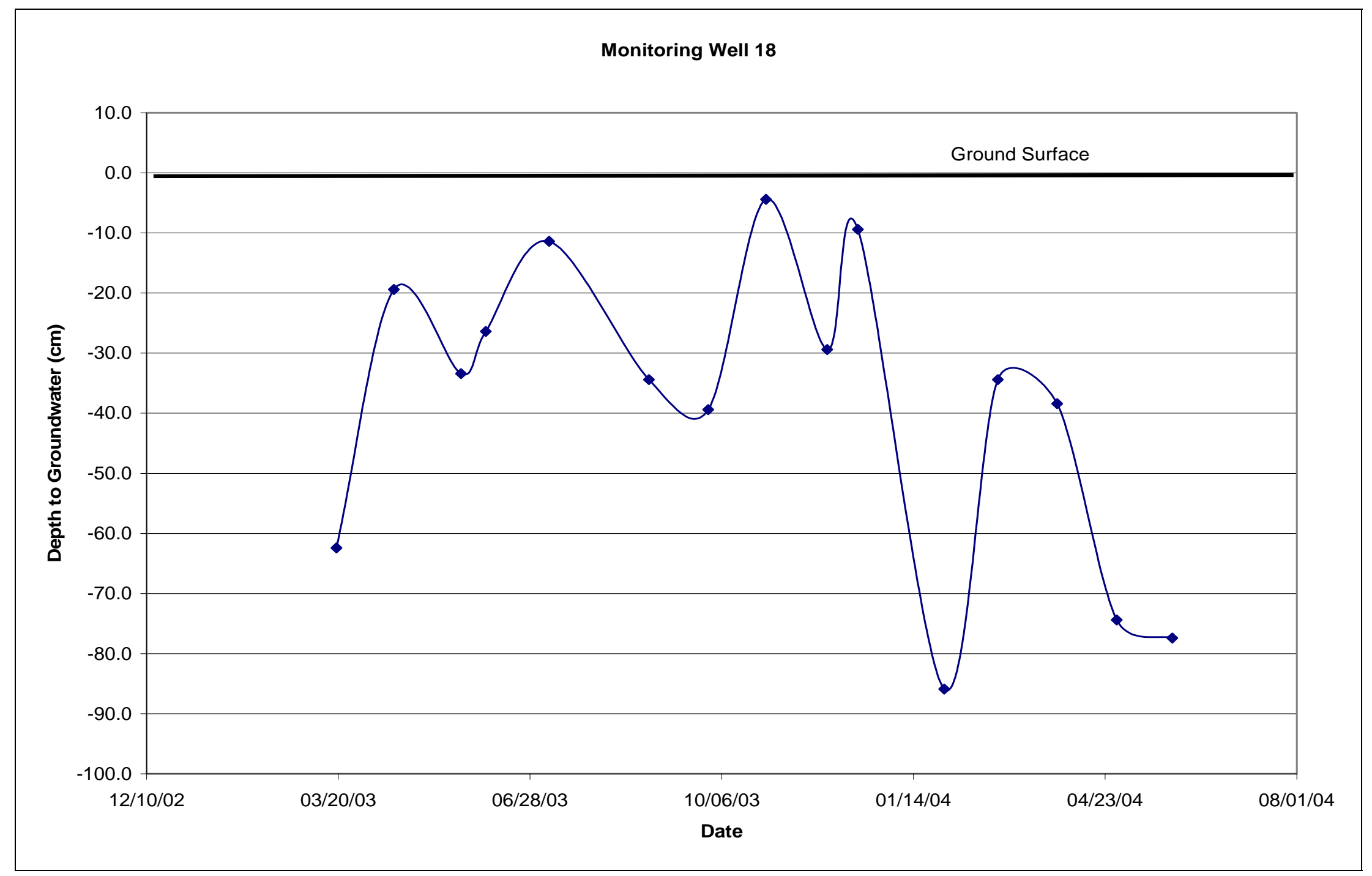

Figure C-20: Well Reading Data for the Monitoring Well 18. 


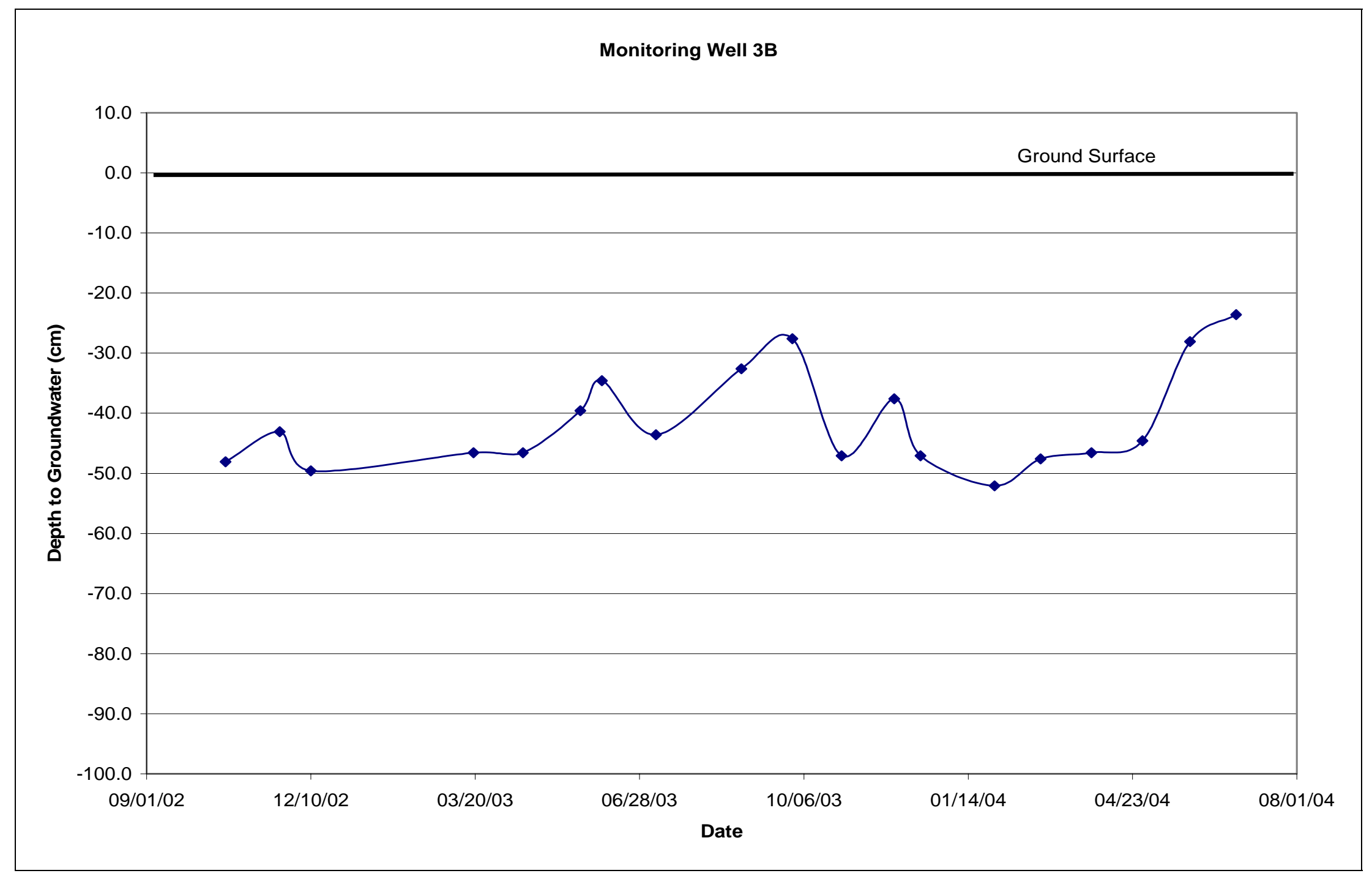

Figure C-21: Well Reading Data for the Monitoring Well 3B. 


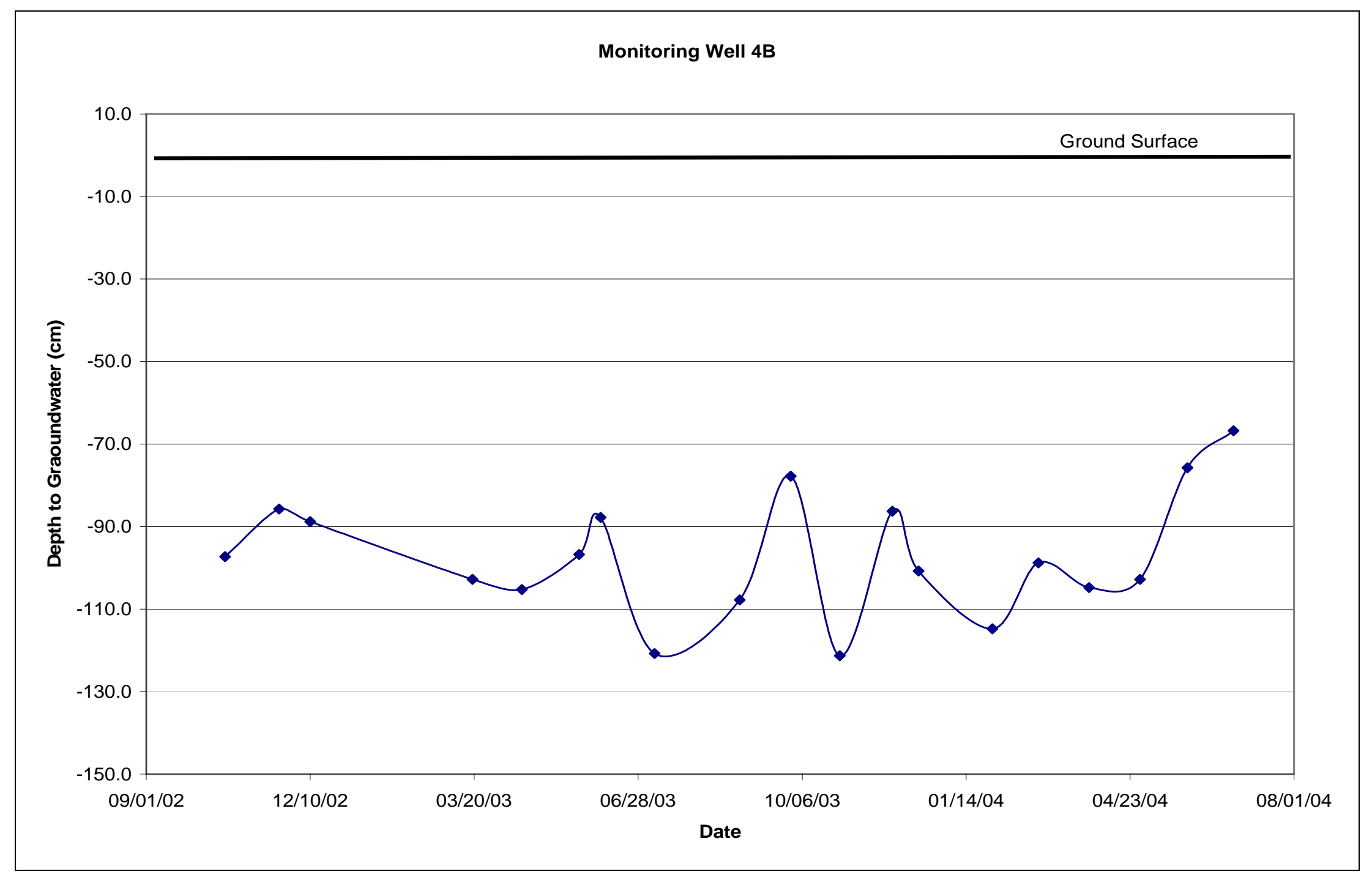

Figure C-22: Well Reading Data for the Monitoring Well 4B. 




Figure C-23: Well Reading Data for the Recording Well 2B. 


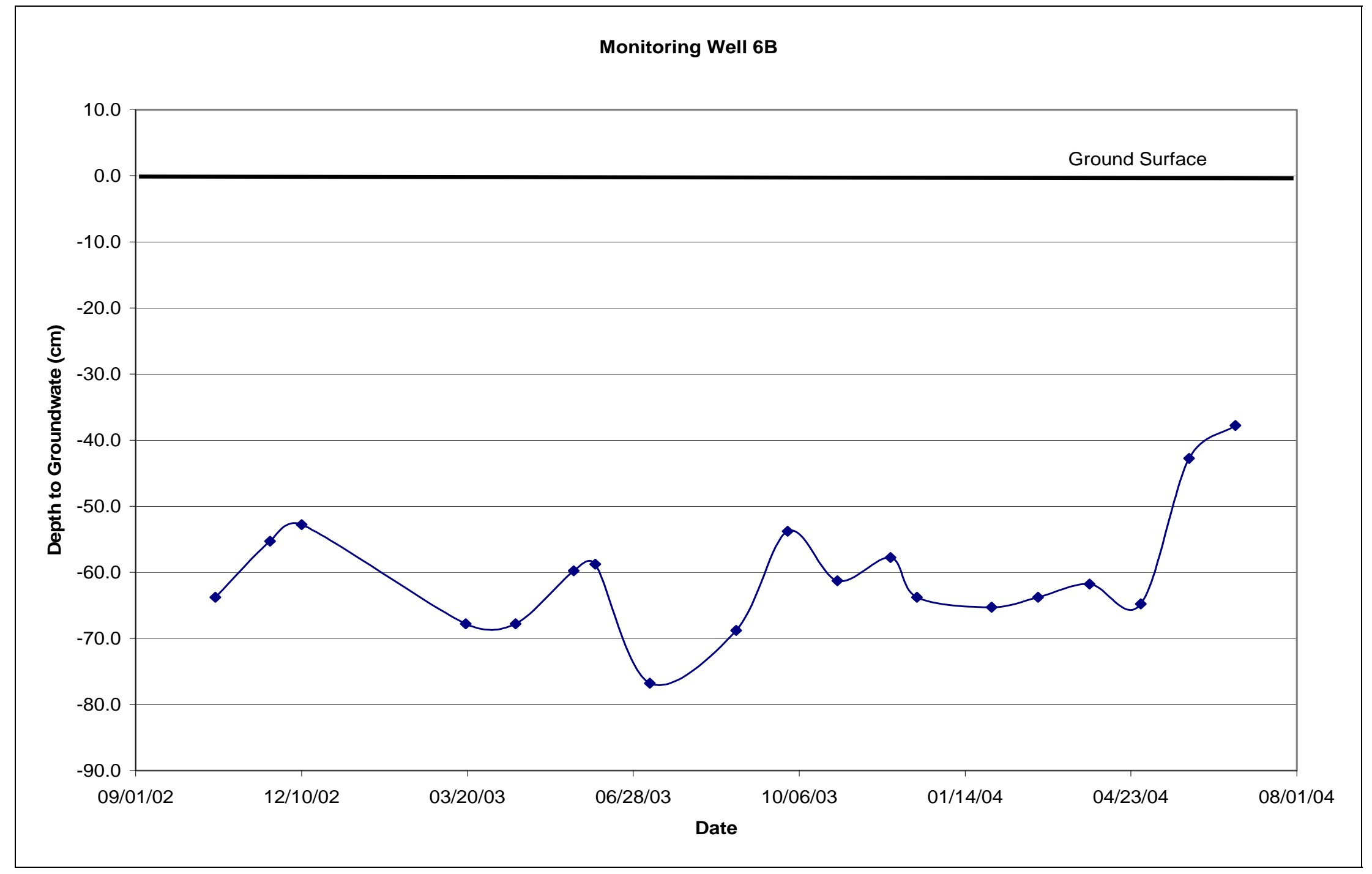

Figure C-24: Well Reading Data for the Monitoring Well 6B. 


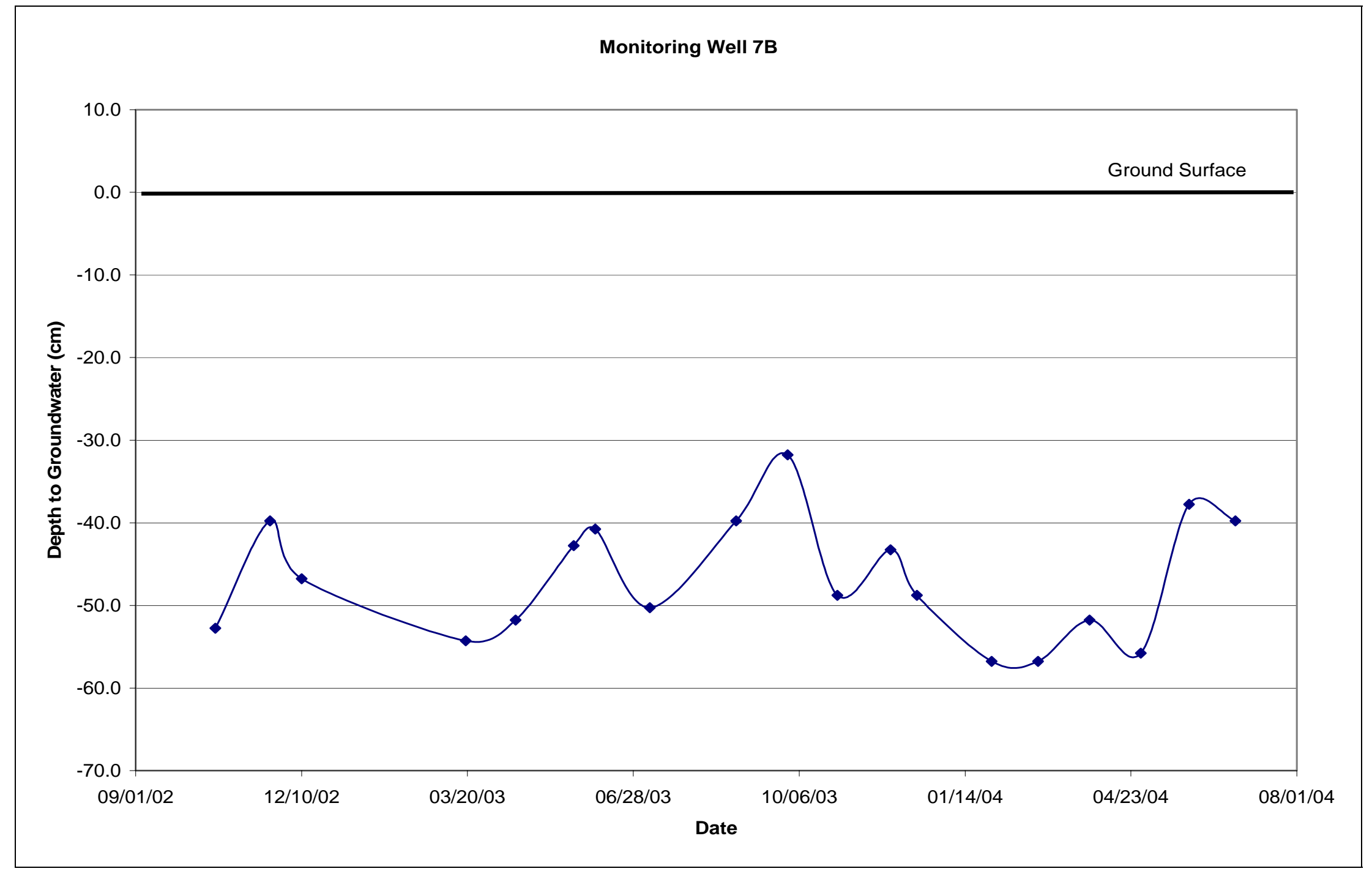

Figure C-25: Well Reading Data for the Monitoring Well 7B. 


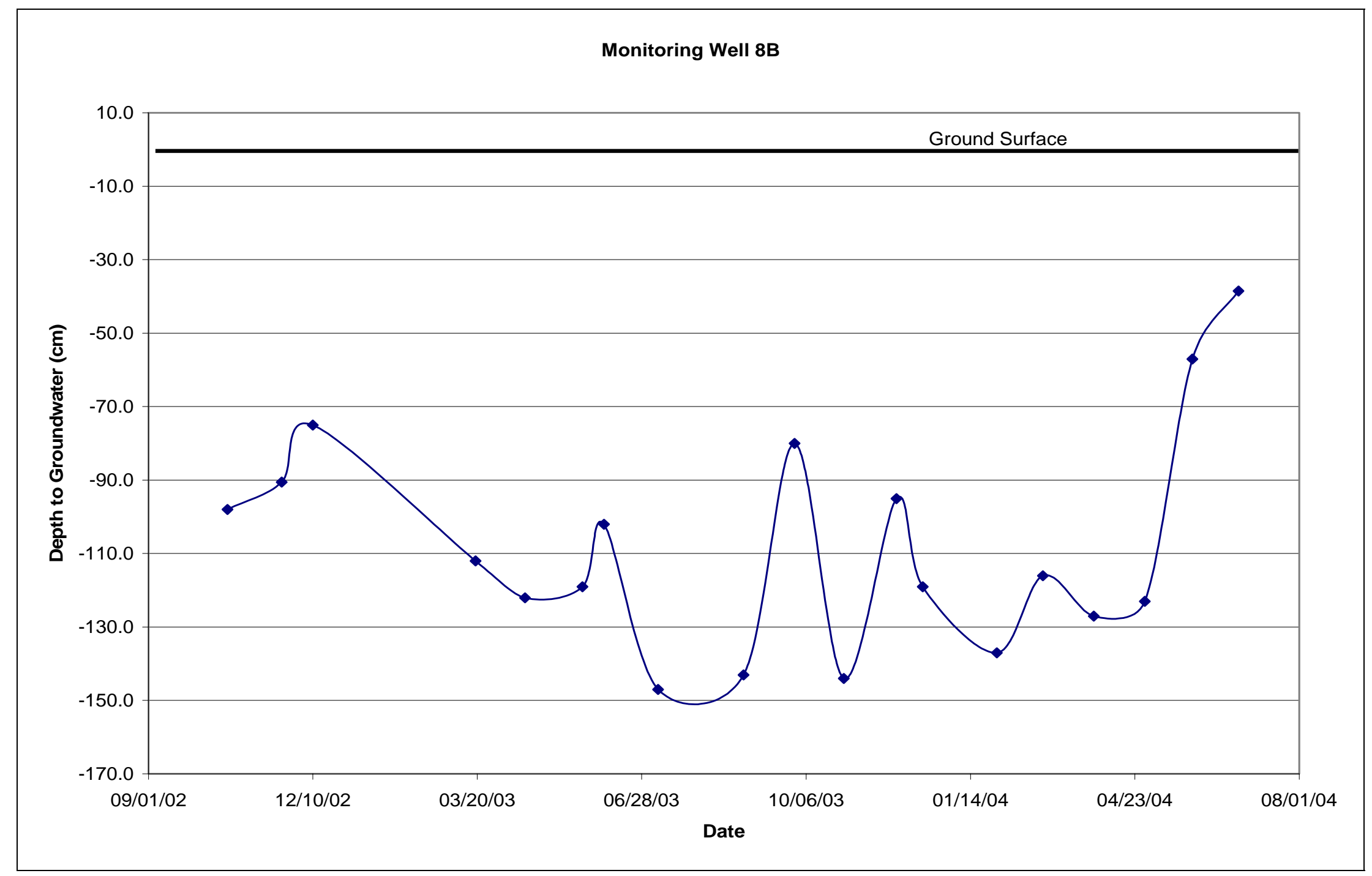

Figure C-26: Well Reading Data for the Monitoring Well 8B. 


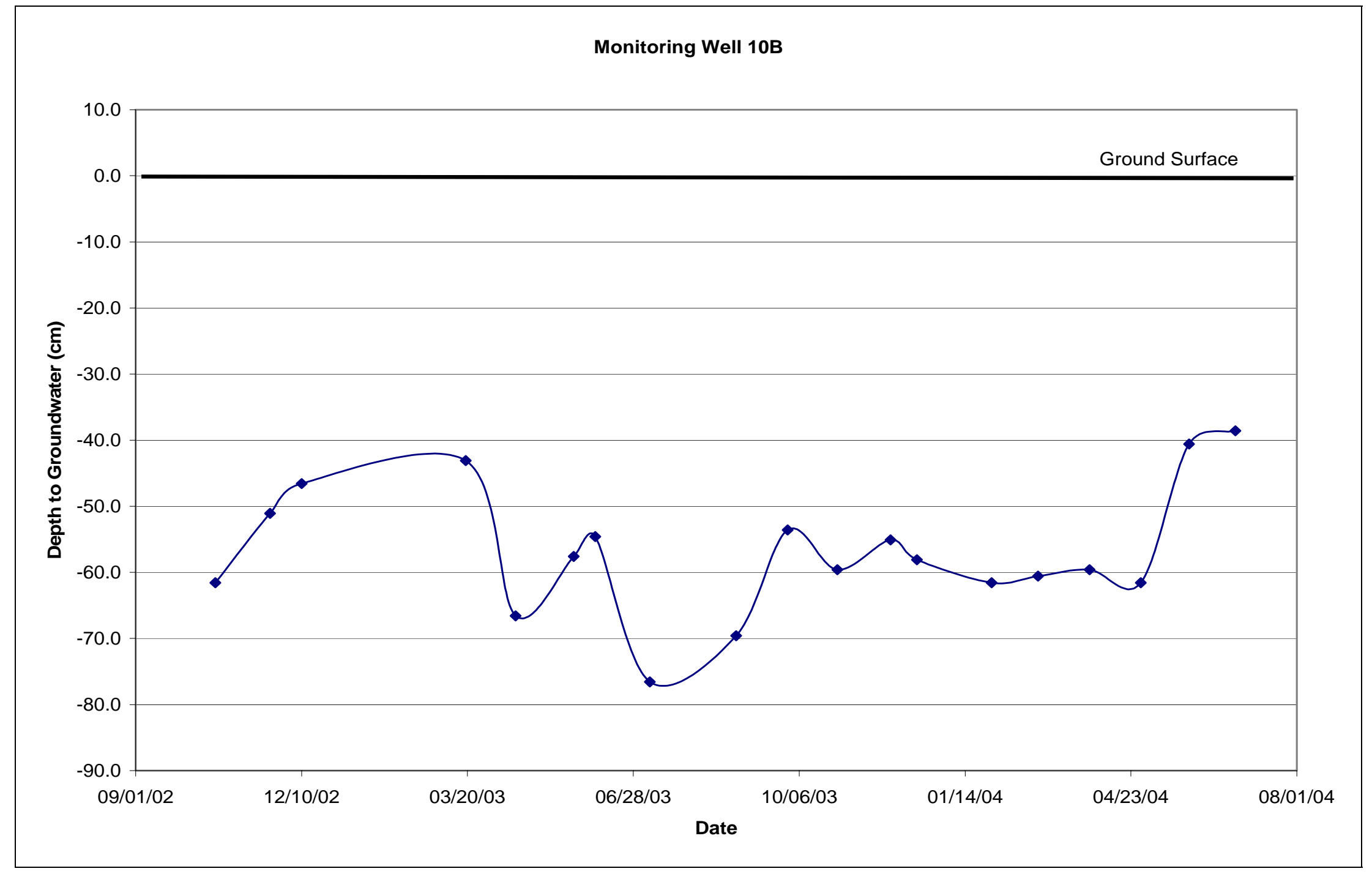

Figure C-27: Well Reading Data for the Monitoring Well 10B. 


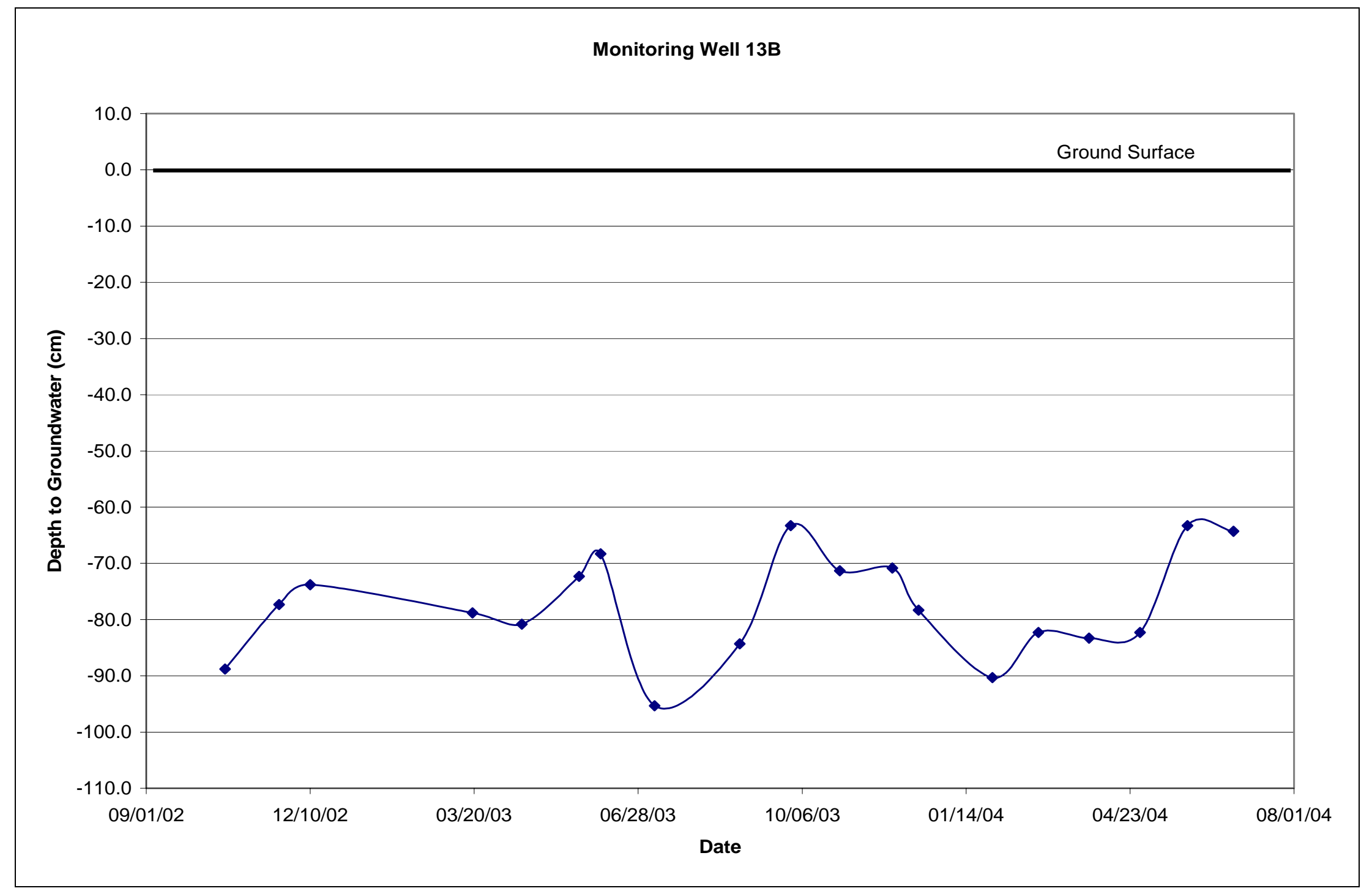

Figure C-28: Well Reading Data for the Monitoring Well 13B. 




Figure C-29: Well Reading Data for the Monitoring Well 15B. 
Appendix D: Water Content Graphs Plotted Versus Depth. 


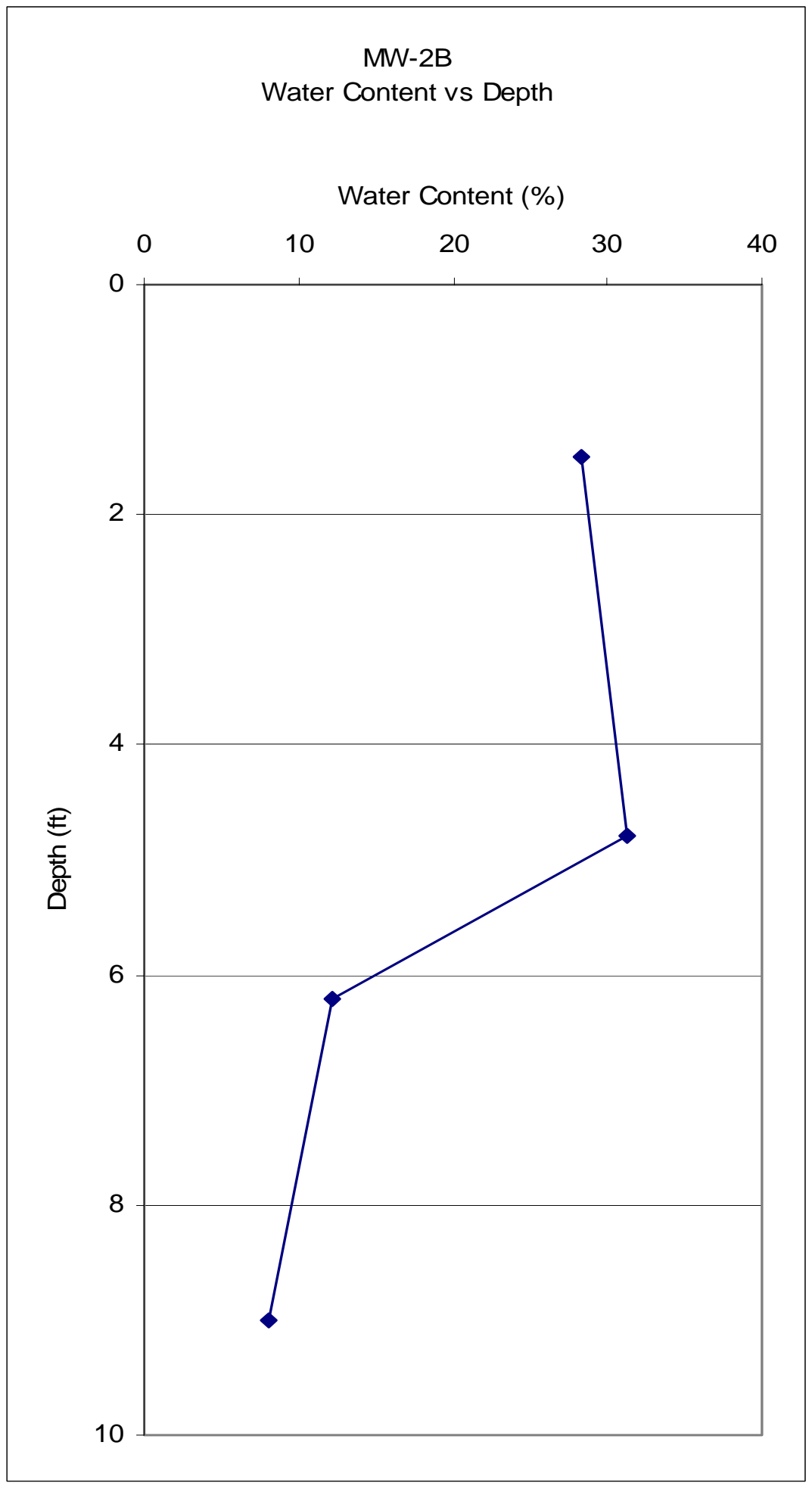

Figure D-1: Water Content vs. Depth at MW-2B. 


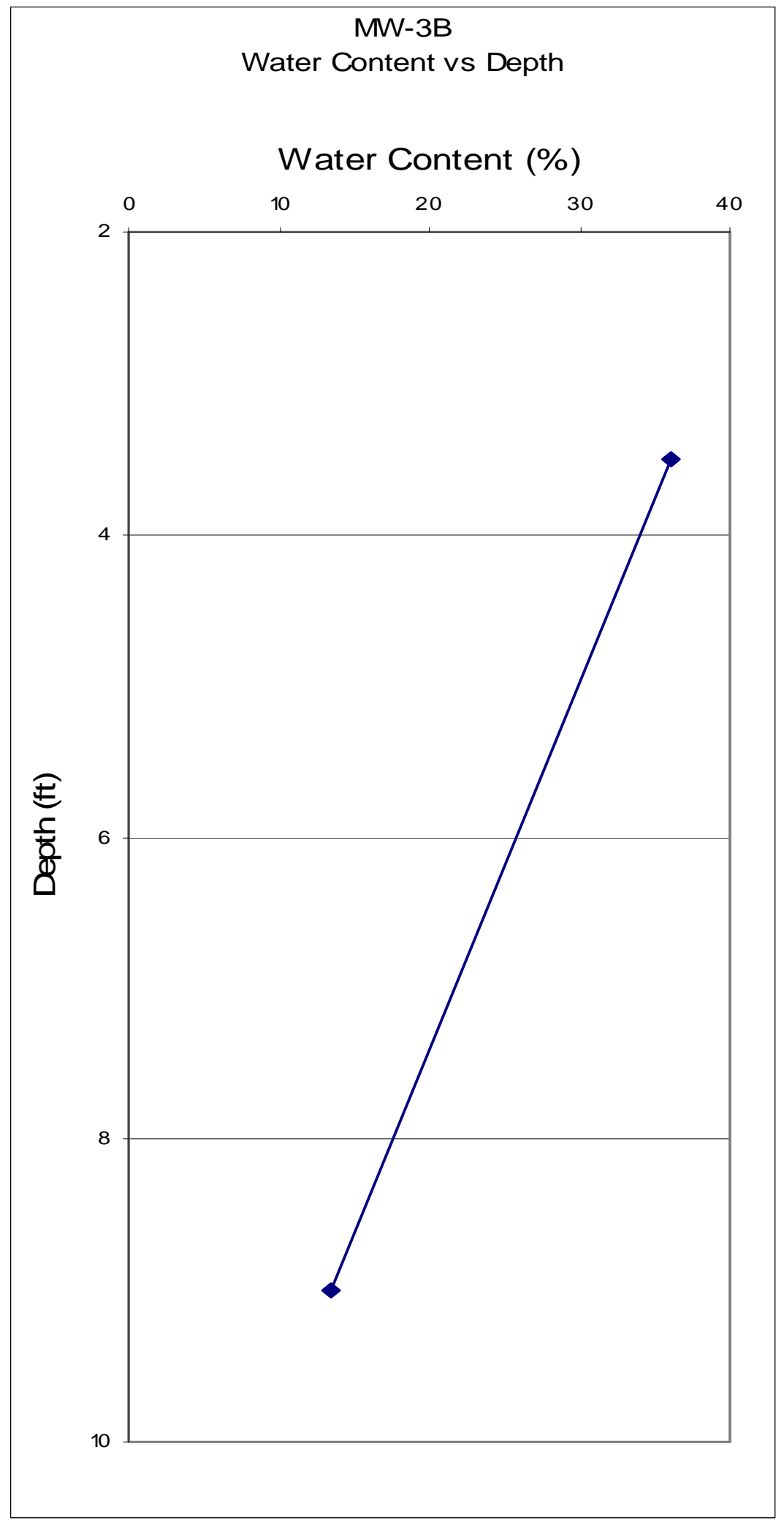

Figure D-2: Water Content vs. Depth at MW-3B. 




Figure D-3: Water Content vs. Depth at MW-4B. 


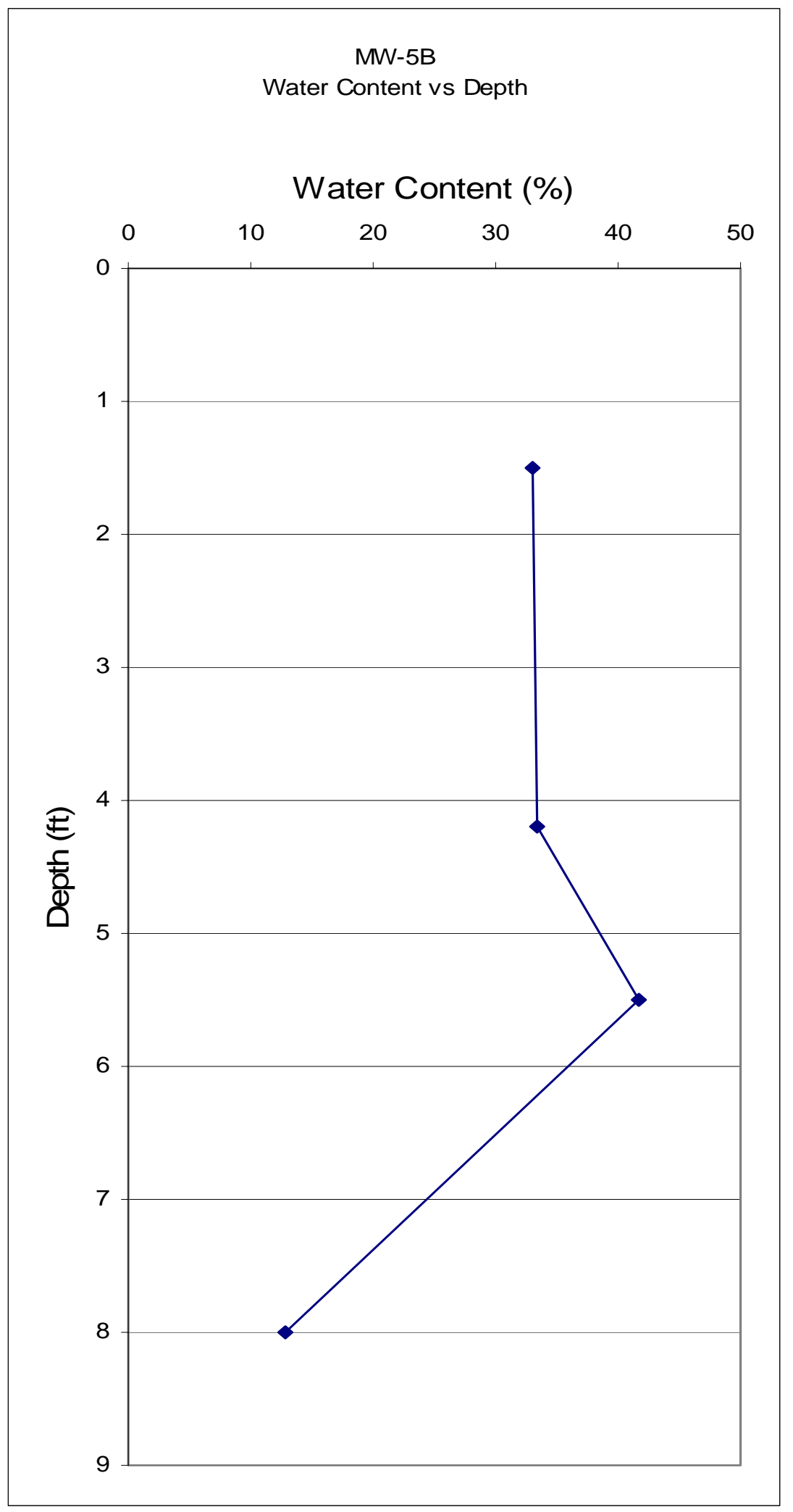

Figure D-4: Water Content vs. Depth at MW-5B. 


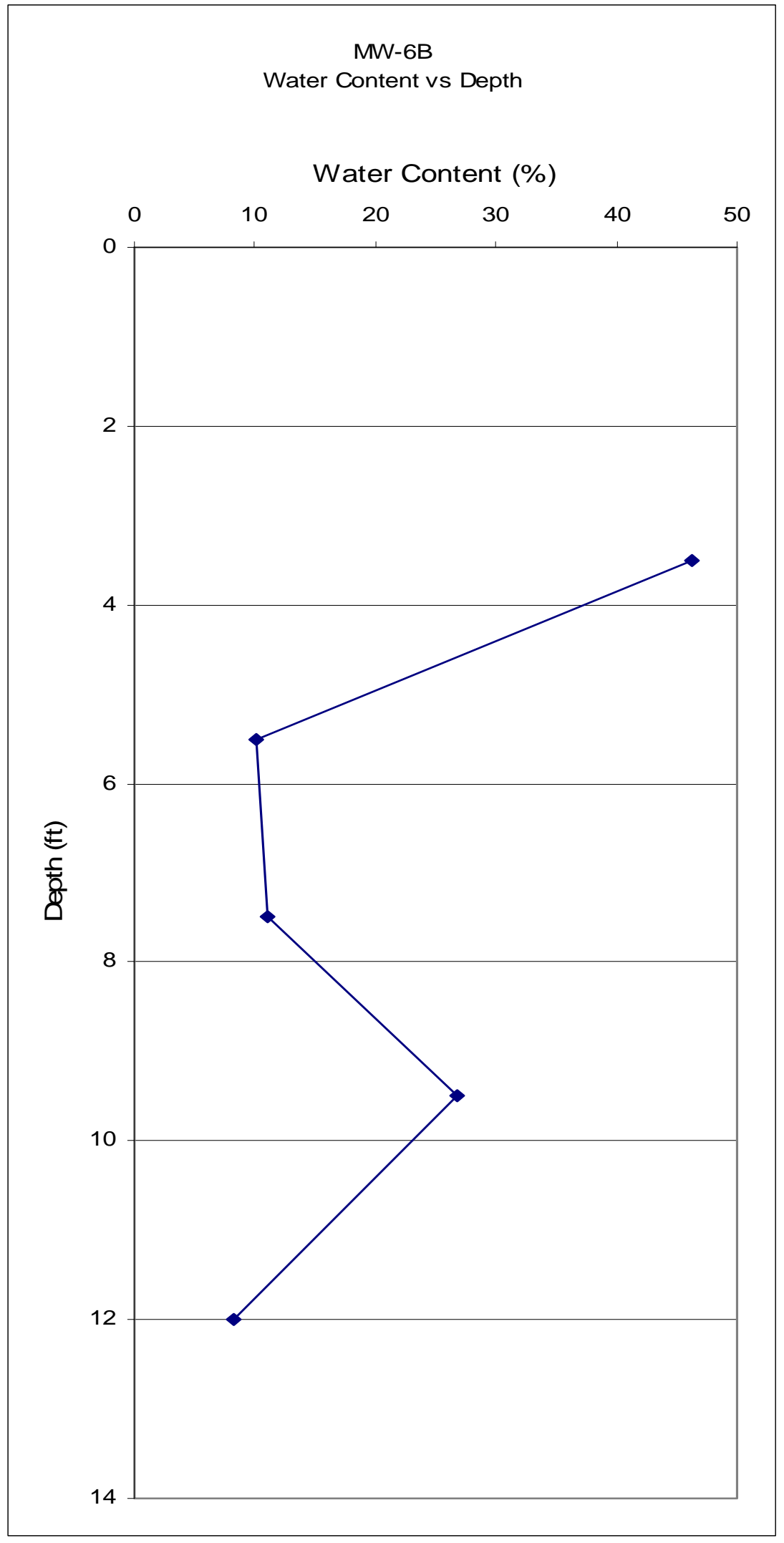

Figure D-5: Water Content vs. Depth at MW-6B. 




Figure D-6: Water Content vs. Depth at MW-7B. 




Figure D-7: Water Content vs. Depth at MW-8B. 


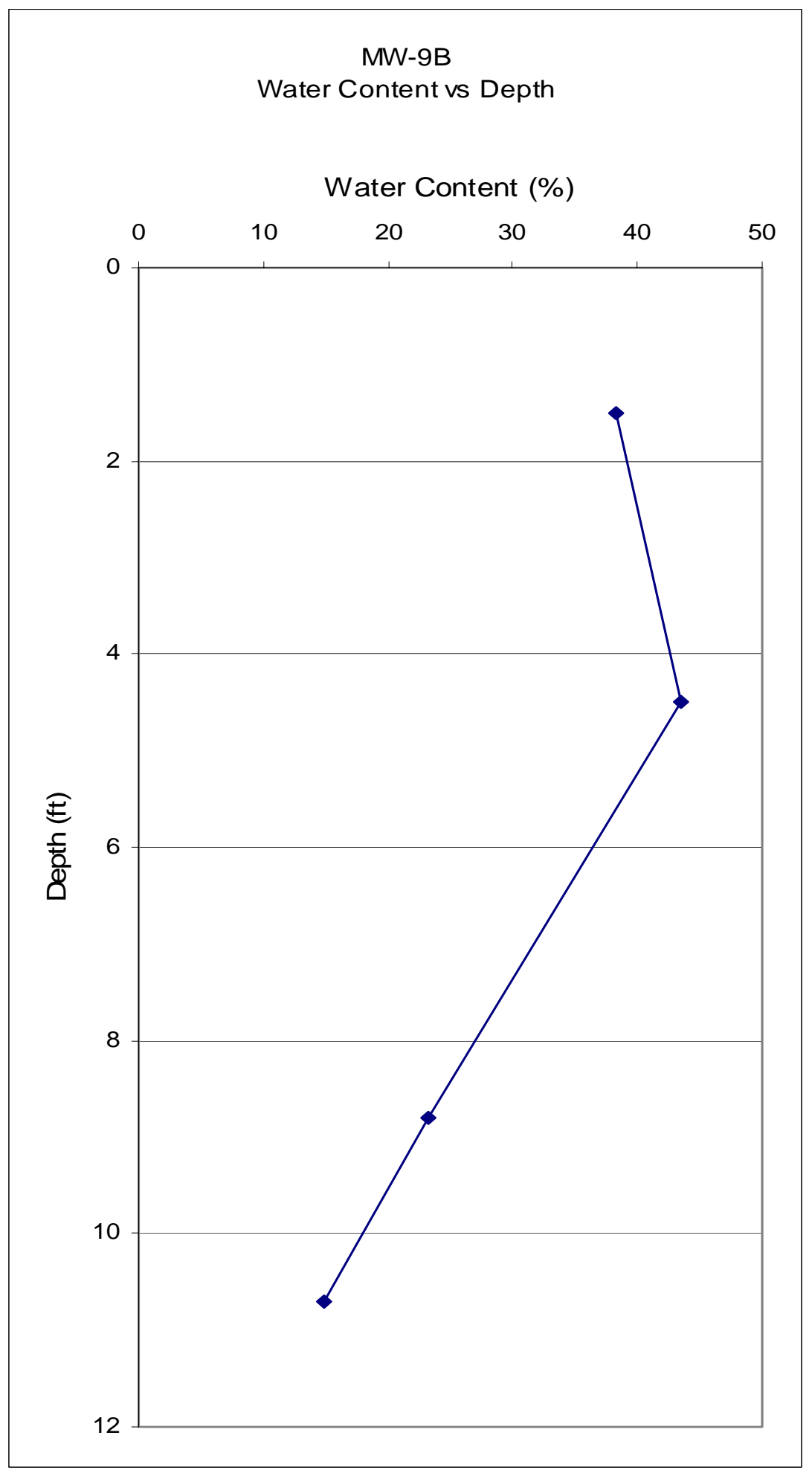

Figure D-8: Water Content vs. Depth at MW-9B. 




Figure D-9: Water Content vs. Depth at MW-10B. 


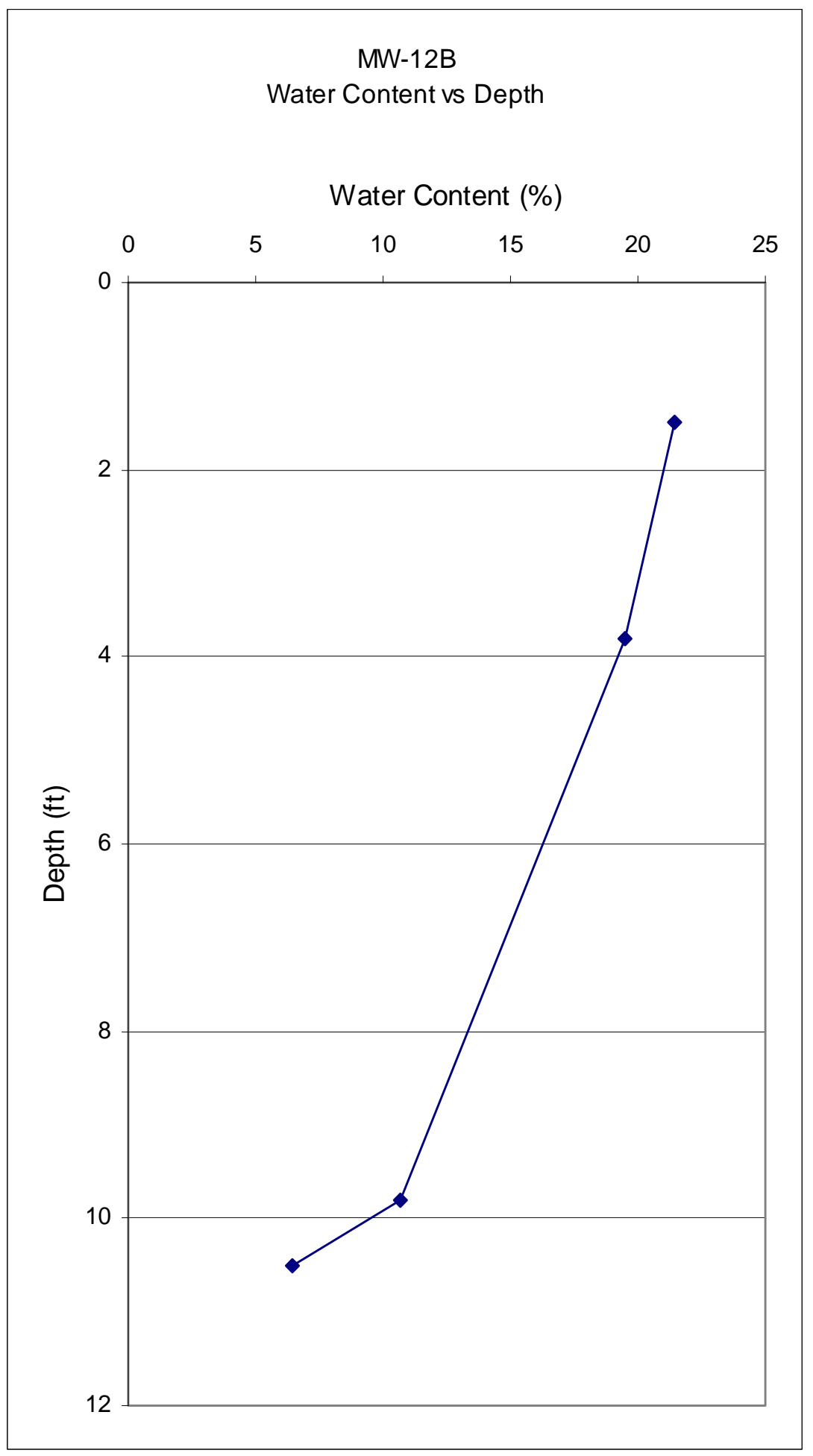

Figure D-10: Water Content vs. Depth at MW-12B. 


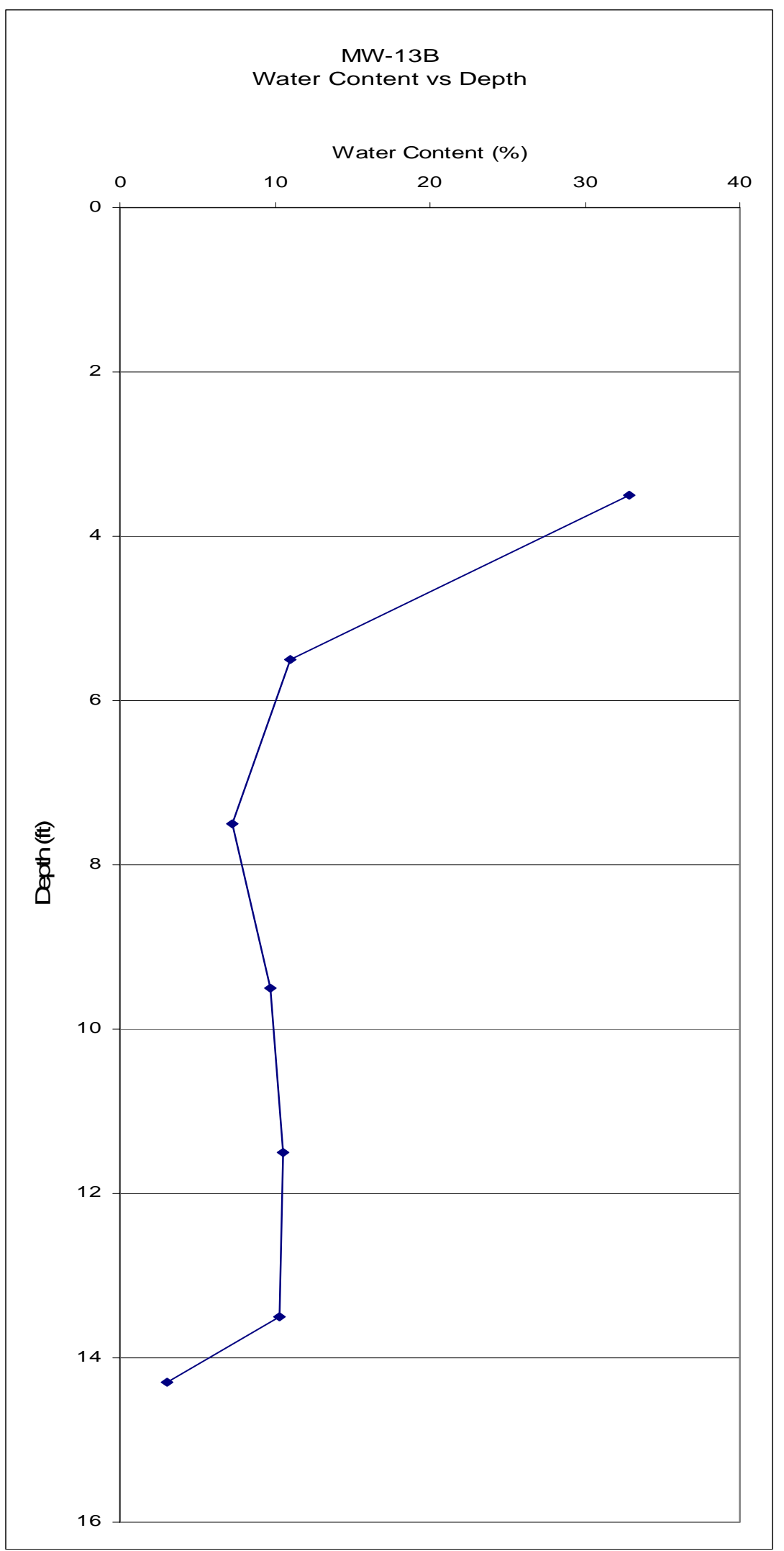

Figure D-11: Water Content vs. Depth at MW-13B. 


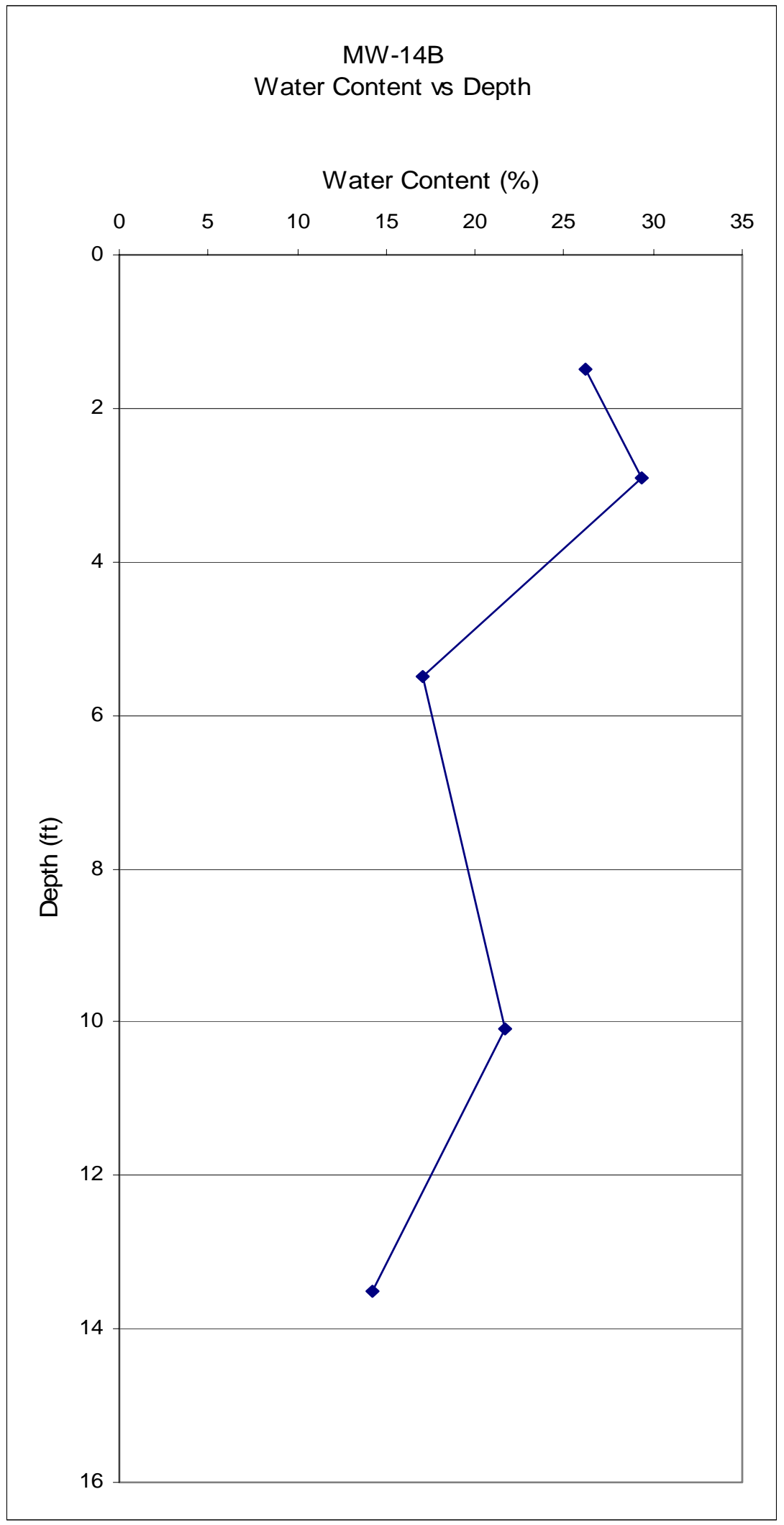

Figure D-12: Water Content vs. Depth at MW-14B. 




Figure D-13: Water Content vs. Depth at MW-15B. 


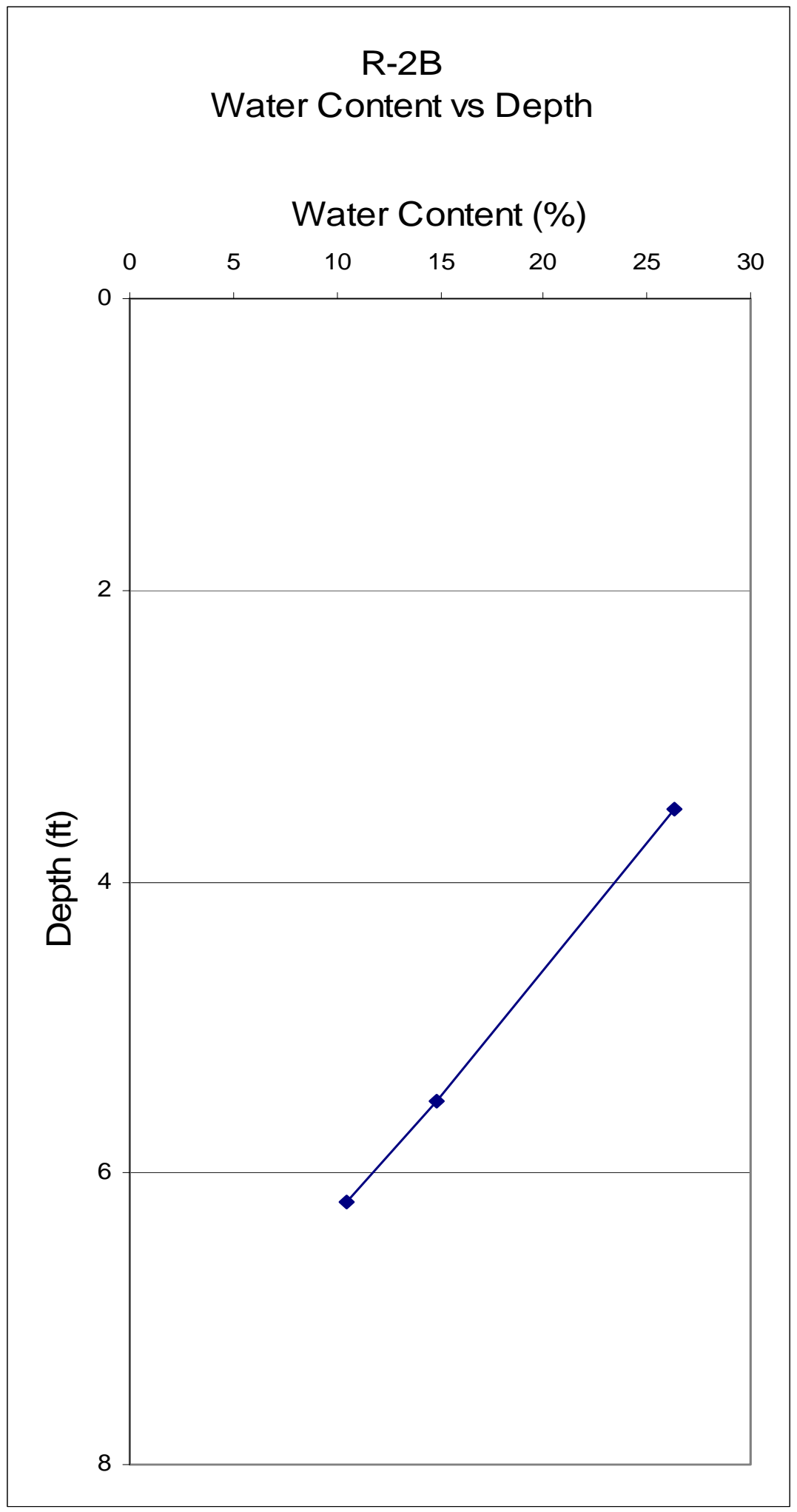

Figure D-14: Water Content vs. Depth at R-2B. 


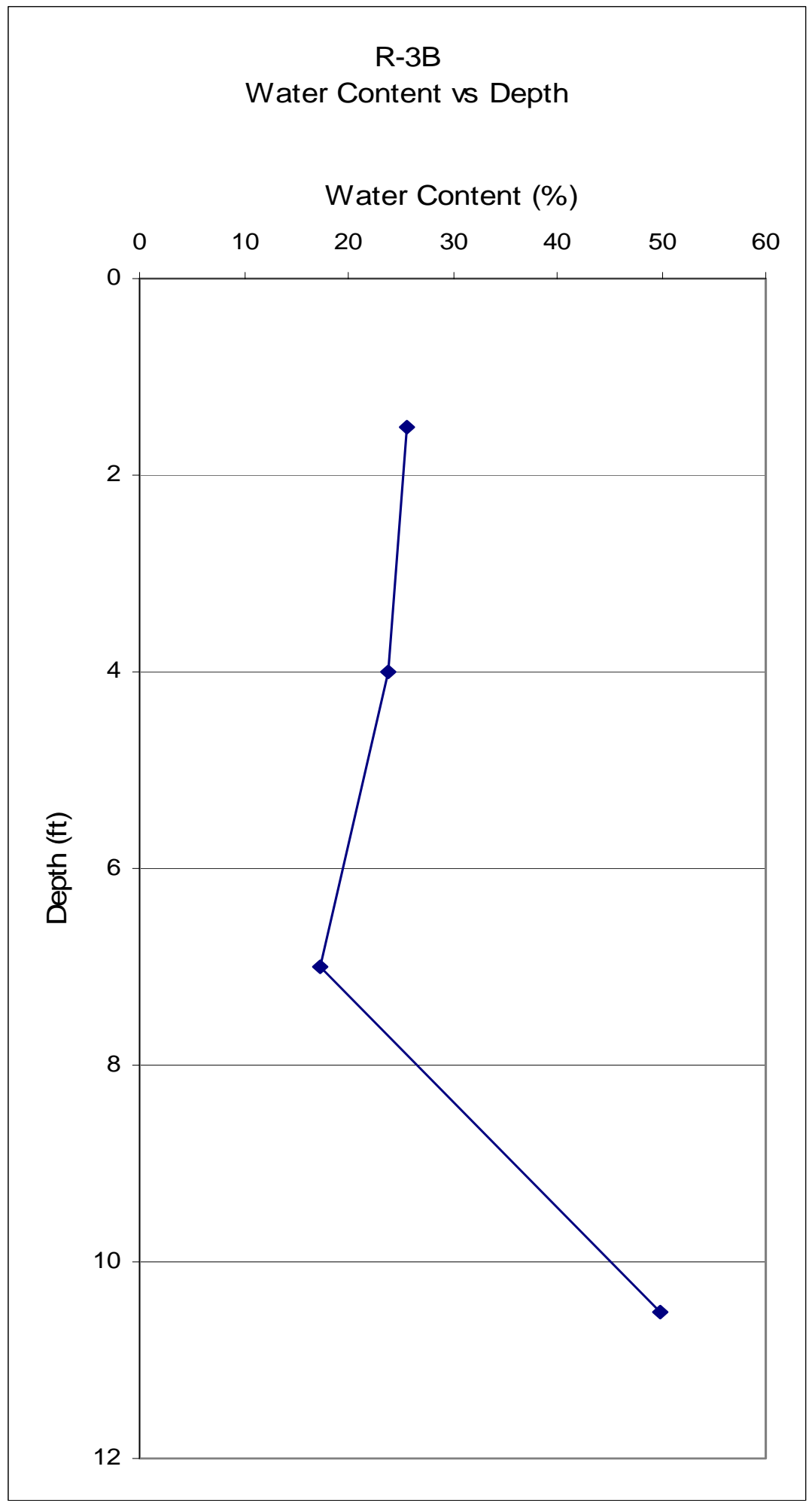

Figure D-15: Water Content vs. Depth at R-3B. 